\author{
Environmental Restoration Division \\ ORNL Environmental Restoration Program
}

\title{
Groundwater Quality Monitoring Well Installation for Waste Area Grouping 17 at Oak Ridge National Laboratory, Oak Ridge, Tennessee
}

\author{
J. A. Mortimore \\ M. L. Ebers
}

Date Issued-September 1994

Prepared for

U.S. Department of Energy

Office of Environmental Restoration and Waste Management under budget and reporting code EW 20

Environmental Restoration and Waste Management Programs

Oak Ridge National Laboratory

Oak Ridge, Tennessee 37831-6285 managed by MARTIN MARIETTA ENERGY SYSTEMS, INC.

for the

U.S. DEPARTMENT OF ENERGY under contract DE-AC05-84OR21400 
Author Affiliations

J. A. Mortimore is staff project manager with the Environmental Restoration Program, Oak Ridge National Laboratory, Martin Marietta Energy Systems, Incorporated. M. L. Ebers is a senior hydrogeologist with Ogden Environmental and Energy Services Co., Inc. (formally ERC Environmental and Energy Services Company). 


\section{DISCLAIMER}

This report was prepared as an account of work sponsored by an agency of the United States Government. Neither the United States Government nor any agency thereof, nor any of their employees, make any warranty, express or implied, or assumes any legal liability or responsibility for the accuracy, completeness, or usefulness of any information, apparatus, product, or process disclosed, or represents that its use would not infringe privately owned rights. Reference herein to any specific commercial product, process, or service by trade name, trademark, manufacturer, or otherwise does not necessarily constitute or imply its endorsement, recommendation, or favoring by the United States Government or any agency thereof. The views and opinions of authors expressed herein do not necessarily state or reflect those of the United States Government or any agency thereof. 



\section{DISCLAIMER}

Portions of this document may be illegible in electronic image products. Images are produced from the best available original document. 



\section{CONTENTS}

EXECUTIVE SUMMARY $\ldots \ldots \ldots \ldots \ldots \ldots \ldots \ldots \ldots \ldots \ldots \ldots \ldots \ldots$

1. INTRODUCTION $\ldots \ldots \ldots \ldots \ldots \ldots \ldots \ldots \ldots \ldots \ldots \ldots \ldots \ldots \ldots \ldots \ldots$

1.1 THE WAG CONCEPT $\ldots \ldots \ldots \ldots \ldots \ldots \ldots \ldots \ldots \ldots \ldots \ldots \ldots \ldots \ldots \ldots$

1.2 DESCRIPTION OF WAG $17 \ldots \ldots \ldots \ldots \ldots \ldots \ldots \ldots \ldots \ldots \ldots$

2. INSTALLATION METHODS $\ldots \ldots \ldots \ldots \ldots \ldots \ldots \ldots \ldots \ldots \ldots, 2$

2.1 TYPE A WELL $\ldots \ldots \ldots \ldots \ldots \ldots \ldots \ldots \ldots \ldots \ldots \ldots \ldots \ldots \ldots \ldots \ldots, 2$

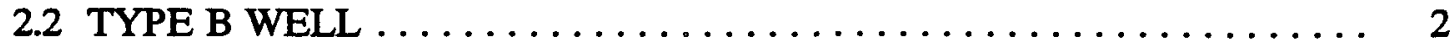

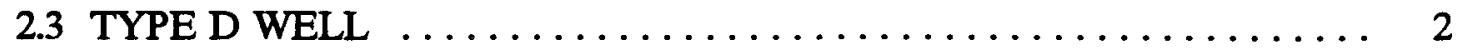

3. ENVIRONMENTAL, HEALTH, AND SAFETY REQUIREMENTS ...... 5

4. FIELD SUPPORT $\ldots \ldots \ldots \ldots \ldots \ldots \ldots \ldots \ldots \ldots \ldots \ldots \ldots \ldots \ldots \ldots \ldots$

5. DRILLING RECORDS $\ldots \ldots \ldots \ldots \ldots \ldots \ldots \ldots \ldots \ldots \ldots \ldots \ldots \ldots \ldots$

6. WELL DEVELOPMENT $\ldots \ldots \ldots \ldots \ldots \ldots \ldots \ldots \ldots \ldots \ldots \ldots$

7. SAMPLING DURING INSTALLATION $\ldots \ldots \ldots \ldots \ldots \ldots \ldots \ldots$

8. SPECIAL NOTES ON INSTALLATION AND DEVELOPMENT $\ldots \ldots \ldots, 10$

REFERENCES $\ldots \ldots \ldots \ldots \ldots \ldots \ldots \ldots \ldots \ldots \ldots \ldots \ldots \ldots \ldots \ldots \ldots \ldots \ldots \ldots$

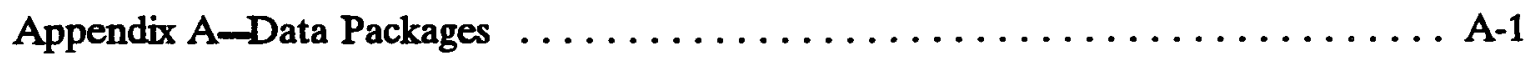

Appendix B-Operating Instructions for Handling Water and Cuttings from

Well Drilling and Development of Groundwater Quality Monitoring Wells ....... B-1 


\section{EXECUTIVE SUMMARY}

This report documents the drilling and installation of groundwater quality monitoring (GQM) wells on the perimeter of Waste Area Grouping (WAG) 17. WAG 17 is composed of approximately 23 acres and is located in Bethel Valley about $3100 \mathrm{ft}$ east of the Oak Ridge National Laboratory (ORNL) main plant area. The facilities in WAG 17 constitute the ORNL Services Area and include the shipping and receiving departments, machine shops, carpenter shops, paint shops, lead burning facilities, tritium facility, and the materials storage area. The wells at WAG 17 were drilled and developed between November 1989 and April 1990. These wells were installed to characterize and assess the WAG in accordance with applicable Department of Energy, state, and Environmental Protection Agency regulatory requirements.

Well design and placement were performed by Martin Marietta Energy Systems, Inc. (Energy Systems) geologic staff and their subcontractors. The wells were drilled, installed, and developed by the subcontractor (Geotek Engineering, Inc.) under contract with Energy Systems. The contract was administered by the Energy Systems Engineering Division for the Environmental Restoration (ER) Program. Hydrogeologic support was provided by an environmental subcontractor [ERC Environmental and Energy Services, Inc. (ERCE)] under contract with Energy Systems. (As of January 1, 1992, ERCE started operating under the name of Ogden Environmental and Energy Services Co., Inc.) This contract was administered by ER Division staff. Radiation protection and industrial hygiene support for the drilling program were provided by Energy Systems staff or their subcontractors.

The wells at WAG 17 were drilled with auger or air rotary rigs. Depending on the hydrogeologic conditions present at each proposed well location, one of four basic installation methods was utilized. Detailed procedures for well construction were specified by the Engineering Division to ensure that the wells would provide water samples representative of the aquifer. To ensure conformance with the specifications, Energy Systems Construction Engineering and ERCE provided continuous oversight of field activities.

The purpose of the well installation program was to install GQM wells for groundwater characterization at WAG 17. Data packages produced during installation activities by the ERCE hydrogeologists are an important product of the program. These packages document the well drilling, installation, and development activities and provide valuable data for well sampling and WAG 17 characterization. The forms contained in the packages include predrilling and postdrilling checklists, drilling and construction logs, development and hydraulic conductivity records, and quality control-related documents. 


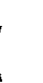

, 


\section{INTRODUCTION}

The purpose of this report is to document the drilling and installation of the groundwater quality monitoring (GQM) wells on the perimeter of Waste Area Grouping (WAG) 17. Installation of GQM wells was required at Oak Ridge National Laboratory (ORNL) for regulatory compliance. Data obtained from these wells will be used to characterize and assess groundwater quality at the perimeter of each WAG in accordance with applicable Department of Energy, state, and Environmental Protection Agency regulatory requirements. The wells in WAG 17 were drilled and developed from November 1989 to April 1990.

\subsection{THE WAG CONCEPT}

At ORNL, the solid waste management units (SWMUs) include solid waste storage areas (SWSAs), pipelines, spill sites, buildings, ponds, and experimental test sites that are considered to be potential sources of contamination. The SWMUs are further grouped into WAGs, the boundaries of which are defined by watersheds that contain contaminants derived from similar assemblages of operating facilities and SWMUs. Basically, the wells are located on or near these boundaries to determine whether contaminants have been released from the WAGs.

\subsection{DESCRIPTION OF WAG 17}

WAG 17 is composed of approximately 23 acres and is located in Bethel Valley about $3100 \mathrm{ft}$ east of the ORNL main plant area [Fig. 1, map pocket (MMES map \#C3E20004A124, Rev. 0)]. The facilities in WAG 17 constitute the ORNL Services Area and include the shipping and receiving departments, machine shops, carpenter shops, paint shops, lead burning facilities, tritium facility, and the materials storage area. Eight groundwater quality monitoring wells were installed along the perimeter of WAG 17 (Fig. 1, map pocket). 


\section{INSTALLATION METHODS}

Four basic types of well construction were used during the GQM installation program at ORNL. Schematic diagrams of these four well types are shown on Fig. 2. Three of the four types were used at WAG 17. These types are described in Sects. 2.1 through 2.2. The specific details of each well installation are included in the monitoring well narratives (Appendix A). The specifications for drilling and well installation were provided in Construction Specifications for Monitoring Wells Installation Construction Project, K-4491G-G1. ${ }^{1}$ The proposed well design criteria for the WAG 17 wells can be found in the report Preliminary Geohydrologic Site Characterization and Proposed Water Quality Well Locations for WAG 17 and Lower WAG 2, ORNL/RAP/Sub/87-SB189/2. ${ }^{2}$ Actual completion data for WAG 17 are listed in Table 1.

\subsection{TYPE A WELL}

The type A well boring is drilled to total depth with solid-stem augers. On completion, the boring is bailed with a steel bailer to remove drill cuttings. The well is completed with 2-in.-diam stainless steel screen, casing, and a silt trap. Stainless steel centralizers are positioned at the top of the screen and every $20 \mathrm{ft}$ along the casing. A sandpack is poured into the annular space from total depth to $1 \mathrm{ft}$ above the screen. Pelleted bentonite is poured into the annular space to create a 2 -ft seal above the sandpack. The top of the bentonite seal is measured with a stainless steel weighted tape. The annular space above the bentonite seal is then grouted to the surface through a tremie pipe.

\section{TYPE B WEIL}

The first step in drilling the type B well is to auger a boring from the surface to a depth of $4 \mathrm{ft}$. A steel diverter casing is installed, and the annulus is grouted to the surface. The boring is then deepened with a tricone air rotary bit to a minimum depth of $10 \mathrm{ft}$ total and $2 \mathrm{ft}$ into bedrock. Next, a steel surface casing is installed and grouted into place. The air rotary method is used to drill the boring to the required depth. The well is completed with 4-in.-diam stainless steel screen and casing. A sandpack, a bentonite seal, and grout are installed in the annular space by the same procedures as used for the type A well.

\section{TYPE D WELL}

A type $D$ well is a type $A$ well with a diverter casing. If the auger encounters refusal before reaching total depth on a type A well, the boring is reamed with a larger auger to refusal, and a steel diverter casing is installed. The annulus is grouted up to surface level. The boring is deepened with a tricone air rotary bit to total depth, and the well is completed with 2-in.-diam stainless steel screen and casing. A sandpack, a bentonite seal, and grout are installed in the annular space by the same procedures as those used for the type A well. 


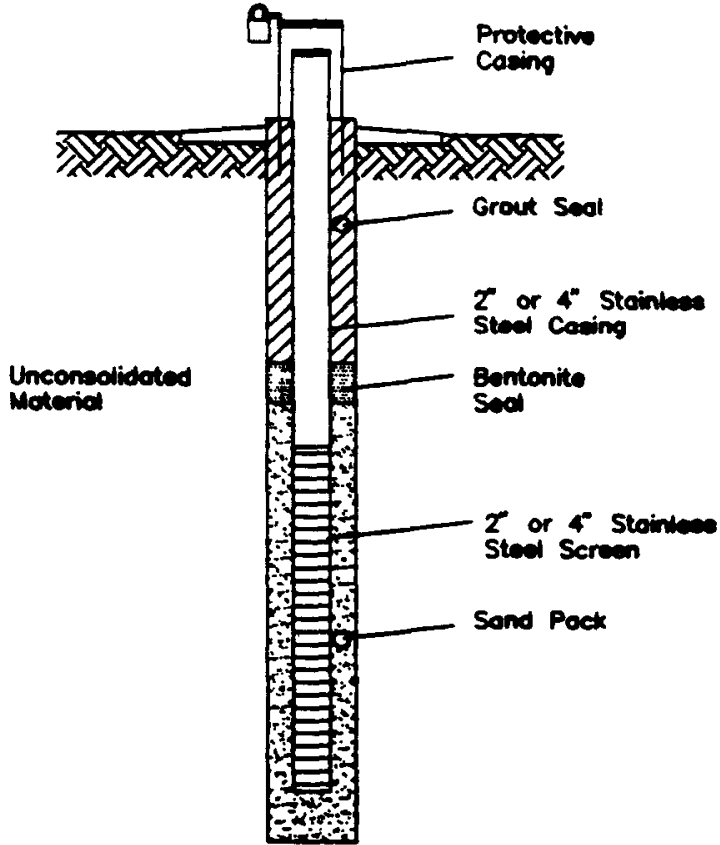

MPE A WELL

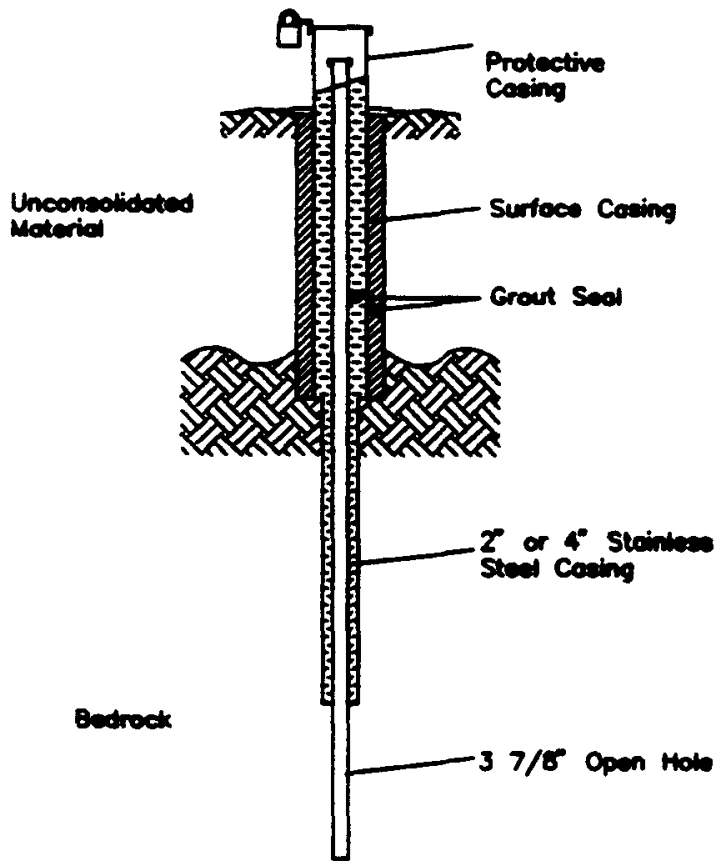

TYPE C WELL

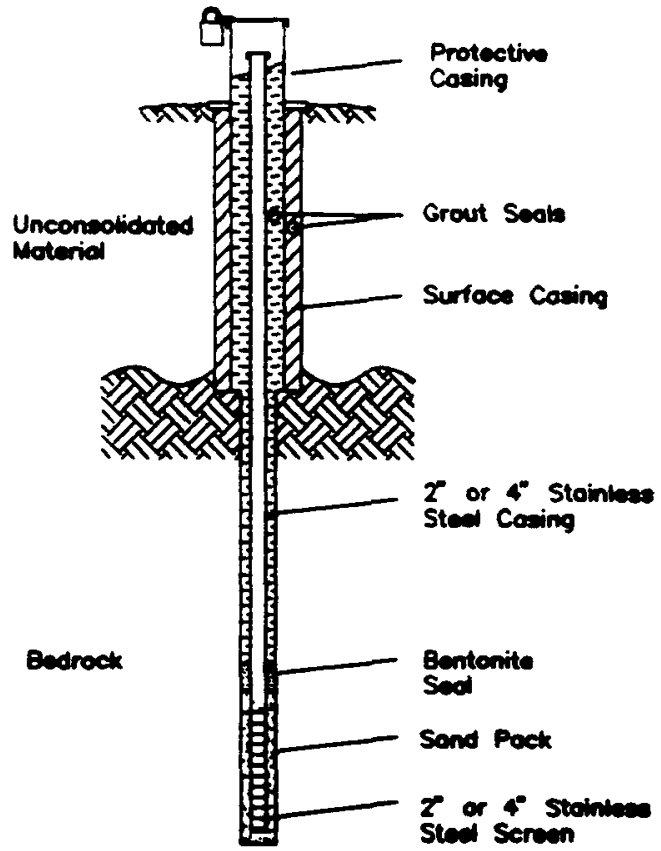

TYPE B WEL

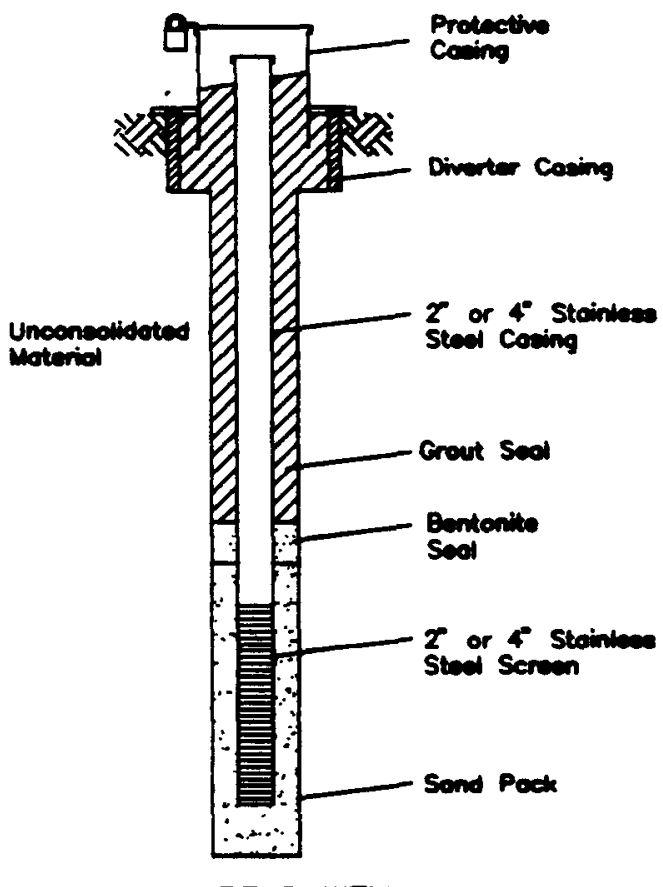

TYPE D WEUL

Fig. 2 The four types of well construction used during the Groundwater Quality Monitoring Well Installation Program at Oak Ridge National Laboratory. 
Table 1. Actual completion for WAG 17

\begin{tabular}{cccccc}
\hline Well & $\begin{array}{c}\text { Depth } \\
\text { clean to } \\
(\mathrm{ft})^{a}\end{array}$ & $\begin{array}{c}\text { SST casing } \\
\text { diam(in.) }\end{array}$ & $\begin{array}{c}\text { Well } \\
\text { type }\end{array}$ & $\begin{array}{c}\text { Screened } \\
\text { interval } \\
(\mathrm{ft})\end{array}$ & $\begin{array}{c}\text { Water } \\
\text { level } \\
(\mathrm{ft})^{b}\end{array}$ \\
\hline 1196 & 18.3 & 2 & D & $8.0-18.0$ & -3.6 \\
1197 & 48.8 & 4 & B & $33.6-48.6$ & -13.6 \\
1198 & 43.0 & 2 & D & $27.8-42.8$ & -25.4 \\
1199 & 72.8 & 4 & B & $52.6-72.6$ & -30.9 \\
1200 & 40.0 & 2 & D & $29.8-39.8$ & -6.3 \\
1201 & 47.8 & 4 & B & $37.6-47.6$ & -4.5 \\
1202 & 20.3 & 4 & B & $10.1-20.1$ & -5.2 \\
1203 & 17.8 & 2 & D & $7.6-17.6$ & -2.8 \\
\hline
\end{tabular}

Total drilled depth may vary from clean-out depth. See data packages (Appendix A).

${ }^{b}$ Predevelopment water level; depth measured from ground surface. (Negative is below surface; positive, above surface.) 


\section{ENVIRONMENTAL, HEALTH, AND SAFETY REQUIREMENTS}

All well drilling at WAG 17 was conducted in accordance with procedures outlined in Health, Safety, and Environmental Protection Procedures for Excavating Operations, ORNL/M-116/R1 ${ }^{3}$. Among the procedures set forth by this document is a system for rating proposed well locations according to the degree of probability that contamination will be encountered. Ratings obtained by this system were used to determine the level of personnel training required and health and safety coverage to be used during drilling.

The Superfund Amendment Reauthorization Act required still more stringent health and safety measures for personnel working in waste areas. These workers were required to have $40 \mathrm{~h}$ of training for hazardous duty through an ORNL-approved course, $8 \mathrm{~h}$ of refresher training each year, $8 \mathrm{~h}$ of supervisor's training for field supervisors, a whole-body count, baseline urinalysis, respirator testing and fitting, and medical monitoring. Personnel were also required to take a construction-worker training course covering the fundamentals of radioactivity and other types of contamination as well as the other hazards that could be encountered at ORNL. The workers were taught the proper procedures to follow in the event of an on-site emergency.

Special procedures were used during drilling. The ground surface at all drill sites was covered with polyethylene sheeting to prevent contact between the tools and the ground. The sheeting would also have protected the environment in the event of a hydraulic fluid release. Containment was required for all drill cuttings produced. During augering, a metal pan was used to hold cuttings until a health physicist (HP) could determine their proper disposition. During air rotary drilling, cuttings were diverted from the borehole to a special containment box designed by Martin Marietta Energy Systems, Inc. (Energy Systems). The box is a 500-gal, trailer-mounted tank with demister elements and high-efficiency particulate air filters at the air exhaust. In order that appropriate methods of disposal could be determined, the tank contents were checked by the HP for radioactive contamination and by the site hydrogeologist for volatile organics. The operating instructions that were followed for determining disposition of the cuttings and water produced during drilling and development are included in Appendix B. 


\section{FIELD SUPPORT}

The construction contractor Geotek Engineering Company, whose contract began in May 1989, installed the GQM wells in WAG 17. ORNL Engineering administered the drilling contract through Energy Systems Procurement. The management organization chart for the project is in the Task Management Plan for Groundwater Quality Monitoring Well Installation, ORNL/RAP/LTR-88/28. ${ }^{4}$

The hydrogeologic support and installation record keeping were supplied through a contract with ERC Environmental and Energy Services Company (ERCE), formerly EDGe/MCI. An ERCE representative was present during all activities that affected the quality of the wells and advised Energy Systems on well construction. ORNL personnel or their subcontractors provided HP and industrial hygiene support.

Construction engineering support was supplied by Energy Systems personnel. Drawings, excavation permits, well placement in the field, and as-built surveying and calculations were done by the Energy Systems Civil and Architectural Department or by their subcontractor, Adams Craft Herz Walker Engineering Company. The as-built survey coordinates and elevations are on the well installation/completion form for each well (Appendix A). The as-built coordinates are also summarized in a table on the well location map (Fig. 1). 


\section{DRILLING RECORDS}

A complete data package has been compiled for each of the GQM wells drilled in WAG 17. These data packages are presented in numerical order in Appendix A. All original records are retained in the Environmental Restoration (ER) Division Records Control Data Base. The forms included in each well data package are listed here in the order in which they appear in the package:

1. monitor well narrative,

2. predrilling checklist for monitoring wells,

3. decontamination checklist for drilling equipment,

4. well log,

5. well installation/completion form,

6. monitoring well materials certification,

7. post-well completion checklist,

8. monitoring well development form,

9. monitoring well development progress,

10 . hydraulic conductivity calculation,

11. nonconformance report (if necessary), and

12. chain of custody forms.

Three additional forms used in the field by the site hydrogeologist but not included in the published data packages are the monitoring well progress form, the hydraulic conductivity test field sheet, and the containment box checklist. These forms are also kept in the ER Division Records Control Data Base. 


\section{WELL DEVELOPMENT}

Wells were developed by pumping. Wells with high initial turbidities were surged beforehand with a workover rig and a stainless steel surge block to facilitate removal of the sediment from the wells. The contents of the wells were then pumped out using Geoguard airlift pumps and oilless air compressors. Development of a well was considered complete when at least three well volumes had been removed and the turbidity was measured at 5 NTUs or less. Several wells had turbidity ratings higher than 5 NTUs even after extensive pumping, but, in order to prevent the pulling in of groundwater from too far away, a maximum limit of 30 to 35 well volumes was determined by Energy Systems hydrogeologists to be the upper limit that should be removed. The contents of the wells were pumped out using Geoguard development pumps. The two-stage Geoguard pumps were converted to dedicated bladder pumps for sampling after development was complete. All development water was contained and disposed of according to the operating instructions in Appendix B.

Of the eight wells in WAG 17, six had turbidities less than or equal to 5 NTUs. The number of well volumes removed ranged from 3.3 to 43.8 , with an average of 22.5 well volumes. The procedure for measuring turbidity described in ORNL/RAP/LTR-88/28 ${ }^{4}$ was replaced with a more accurate method. While the previously used method depended on a visual comparison of the sample with prepared standards, the new method employs the ColeParmer turbidimeter, which measures NTUs by passing a lens-focused light beam through a test tube filled with a water sample. A photosensor detects the intensity of the exiting light beam, and an analog scale on the instrument displays the turbidity of the sample. 


\section{SAMPLING DURING INSTALLATION}

The ERCE hydrogeologist took samples of soil, rock, and drilling water during well installation and submitted them to the ORNL Analytical Chemistry Division for chemical analyses. Soil and rock samples were taken from the unsaturated and saturated zones. Samples of drilling water were collected from the water pump discharge on the drill rig during air rotary drilling. All samples were transferred using chain-of-custody forms, which are included in the data packages. The sampling procedures are explained in ORNL/RAP/Ltr-88/284. Soil samples were collected from each single well and from one well of each well pair. A drilling-water sample was collected from each air-rotary-drilled boring.

Analyses for 31 chemical elements, gross alpha, gross beta, and ${ }^{40} \mathrm{~K}$ were routinely performed on the soil and water samples. The results from these analyses are contained in the ER Division Records Control Data Base. 


\section{SPECIAL NOTES ON INSTALLATION AND DEVELOPMENT}

Soil samples were collected from wells 1196, 1197, 1198 and 1199 by Bechtel National, Inc., the Remedial Investigation/Feasibility Study subcontractor. Analytical results for these soil samples can be obtained from Bechtel. 


\section{REFERENCES}

1. Engineering Division, Construction Specifications for Monitoring Wells Installation Construction Project, K-4491G-G1 (Rev. 2), Martin Marietta Energy Systems, Inc., Oak Ridge National Laboratory, Oak Ridge, Tenn. August 1988.

2. Engineering, Design \& Geosciences Group, Inc., Preliminary Geohydrologic Site Characterization and Proposed Water Quality Well Locations For WAG 17 and Lower WAG 2, ORNL/RAP/Sub-87/SB189/2, Martin Marietta Energy Systems, Inc., Oak Ridge National Laboratory, Oak Ridge, Tenn., September 1987.

3. Environmental Compliance and Health Protection Division, Health, Safety, and Environmental Protection Procedures for Excavating Operations, ORNL/M-116/R1, Martin Marietta Energy Systems, Inc., Oak Ridge National Laboratory, Oak Ridge, Tenn., March 3, 1988.

4. J. A. Mortimore, Task Management Plan for Groundwater Quality Monitoring Well Installation, ORNL/RAP/LTR-88/28, Martin Marietta Energy Systems, Inc., Oak Ridge National Laboratory, Oak Ridge, Tenn., February 1988. 
|

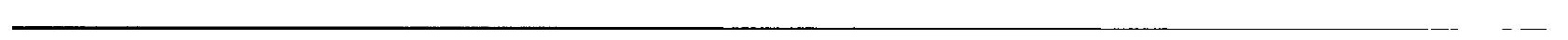


Appendix A

Data Packages 
1.0 General Information

1.1 We11 Location

Monitoring well number 1196 is located in WAG 17. It is located in the northeast corner of WAG 17 approximately $120^{\prime}$ northeast of Bldg. 7012. The location is shown on ORNL drawing number C3E20004A075. Survey coordinates for this well are $N 21,988.5166, \mathrm{E} 37,553.8509$ (X-10 grid) or latitude $35^{\circ}-56^{\circ}-11.32^{\prime}$ and longitude $84^{\circ}-17^{\prime}-$ 54.78". Coordinate data were provided by Martin Marietta Energy systems. The method used for conversion from $x-10$ grid to Tennessee-Lambert state Plane Coordinates came from the publication "Tennessee Valley Authority Data Services Branch and Mapping Services Branch, Oak Ridge, Tennessee, DOE Plant Control, November 6, 1985, Field Book: Ess-3115, pp. 1-20." The latitude and longitude were calculated by Adams Craft Herz Walker Engineering, Inc., using methods from the U.S. Coast and Geodetic Survey Publication 62-4, "state Plane Coordinates by Automatic Data Processing."

\subsection{Drilling Information}

Well number 1196 was drilled by Geotek Engineering Company. A Schramm Rotadrill rig was used to drill this boring for monitor well installation under the operation of George Akins with the assistance of steve Kirk. Drilling commenced on $11 / 7 / 89$ and was finished on 11/21/89. Paragraph 2.4.1 includes a detailed discussion of the well installation and a well schematic is included on the well installation/completion form. A synopsis of the drilling activity follows. This information was typed directly from fleld notes and was edited only when necessary for clarification. 
11-7-89: The Schramm was mobilized to the staked location and set up on plastic. Split spoon samples were taken from surface to 8.31 .

11-8-89: The boring was augered with a 6" auger to refusal at 10.81 . The boring was then augered with a 14 " auger to 8.6 feet set 7.6 feet of 10 $3 / 4$ " diverter casing and grouted it with 4 sacks of cement. The rig was moved off the hole.

11-20-89: The Schramm rig moved to location and set up on plastic. The boring was deepened to $15.0^{\prime}$ using a 77/8 inch air rotary tri-cone bit.

11-21-89: The boring was deepened to 18.3'. 18.0' feet of 2 inch stainless steel casing was set and a sand pack was placed from 7.0 feet to 18.3 feet. A 2.1 feet bentonite seal was placed on the sand pack. The rig was moved off location. The annular space was grouted from the top of the bentonite seal to surface.

This well was logged by the EDGe Group of ERC Environmental and Energy Services Co., Inc., hydrogeologist Timothy A. Lee. All well construction materials and supplies were from Martin Marietta Energy Systems approved batches. The batch origin of individual items is shown on the included Monitoring well vaterials certification form. 
2.0 Technical Information

2.1 Decontamination Procedures

The drilling rig, down hole tools, surface casing, stainless steel screen, stainless steel casing, centralizers, and stainless steel silt trap underwent the cleaning decontamination procedures outlined in the drilling specifications (Release Specific Technical Directions for Regulatory Compliance Monitoring Wells, Phase 1, Oak Ridge National Laboratory, Oak Ridge, w.0. K4147, April 1987, pgs. 2-4). A checklist of the cleaned materials is included with this data package.

\section{$2.2600 \log Y$}

WAG 17 encompasses approximately 23 acres in Bethel valley, which is in the Valley and Ridge Physiographic Province of East Tennessee. WAG 17 is underlain by the Middle Ordovician Chickamauga Group consisting mainly of limestone and siltstone. The Chickamauga Group consists of eight units, designated by letters A through H (Stockdale, 1951). WAG 17 is underlain by units E, F, G and a portion of $H$. These unite consist of thin bedded nodular limestone with clay and shale partings. Portions of units $H$ and $F$ consist of calcareous siltetone alternating with beds of olive gray to maroon chale. The regional strike is $56^{\circ}$ northeast and has a moderate dip of $30^{\circ}$ to $40^{\circ}$ southeast.

\subsection{Benple collection}

Soil samples were collected during drilling by Bechtel National, Inc., the Remedial Investigation/Feasibility 
study subcontractor. A drill water sample was collected from the water pump on the drill rig on 11-20-89. Analytical results for the soil samples described above can be obtained from Bechtel. The analytical results for the drill water sample can be obtained from the Remedial Action Program data base at ORNL.

A bulk density soil sample was collected from the split spoon sample interval from 6.5 to 6.85 feet. The sample was measured and weighed, and a bulk density of 2.08 grams $/ \mathrm{cm}^{3}$ was calculated.

The Schramm rig compressed air was sampled with a cloth filter inserted between drill rods on 11-20-89. The sample was examined with an ultraviolet light for the presence of hydrocarbons. The filter showed no evidence of hydrocarbons.

\subsection{Ineteliation and Dovelopment}

\subsubsection{Instaliation}

This was a type D well. A 6-inch diameter boring was split spooned from ground surface to auger refusal (10.8 feet). The air rotary method was required to complete the boring to the opecifled total well depth. Therefore, a 14-inch diameter boring was augered from ground surface to 7.6 feet and a 10 3/4-inch diverter casing was installed and grouted. An 8-inch diameter boring was then drilled with an air rotary tricone roller bit from 7.6 to 18.3 feet. A 2-inch diameter stainless steel screen with welded bottom cap was installed from 8.0 to 18.3 feet. A 2-inch diameter stainless steel casing was installed above the screen at 
8.0 feet and extended 1.18 feet above ground surface. A sandpack was then tremied into the annular space from 7.0 to 18.3 feet, with a 2.1-foot bentonite pellet seal poured into the annular space above the sandpack from 4.9 to 7.0 feet. The annular space from the top of the bentonite seal to the surface was tremie-grouted with a cement/bentonite slurry. A detailed schematic of the well is included on the well installation/completion form.

\subsubsection{Well Development}

Well number 1196 was developed to remove drill cuttings, silt, and other fines. The monitoring well was developed using a Geoguard pump with an air compressor. All pumps were cleaned prior to use according to specified cleaning procedures (see Paragraph 2.1). The well was developed until a measured total of 297 gallons of water had been evacuated and the clarity of the discharge water was approved by the company representa-tive. The final turbidity value measured at completion was 5.0 NTU's. A development form showing the exact method of development and other pertinent data is appended.

\subsubsection{Installation of Dedicated Monitoring Well Pump}

After the well was developed, a Geoguard Model No. 5614 dedicated monitoring well pump was installed on 4-18-90 at a depth of 17.3 feet below ground surface. These pumps are decontaminated at American Sigma and are sent prepackaged. A copy of the pump certification is kept on file at ORNL. 


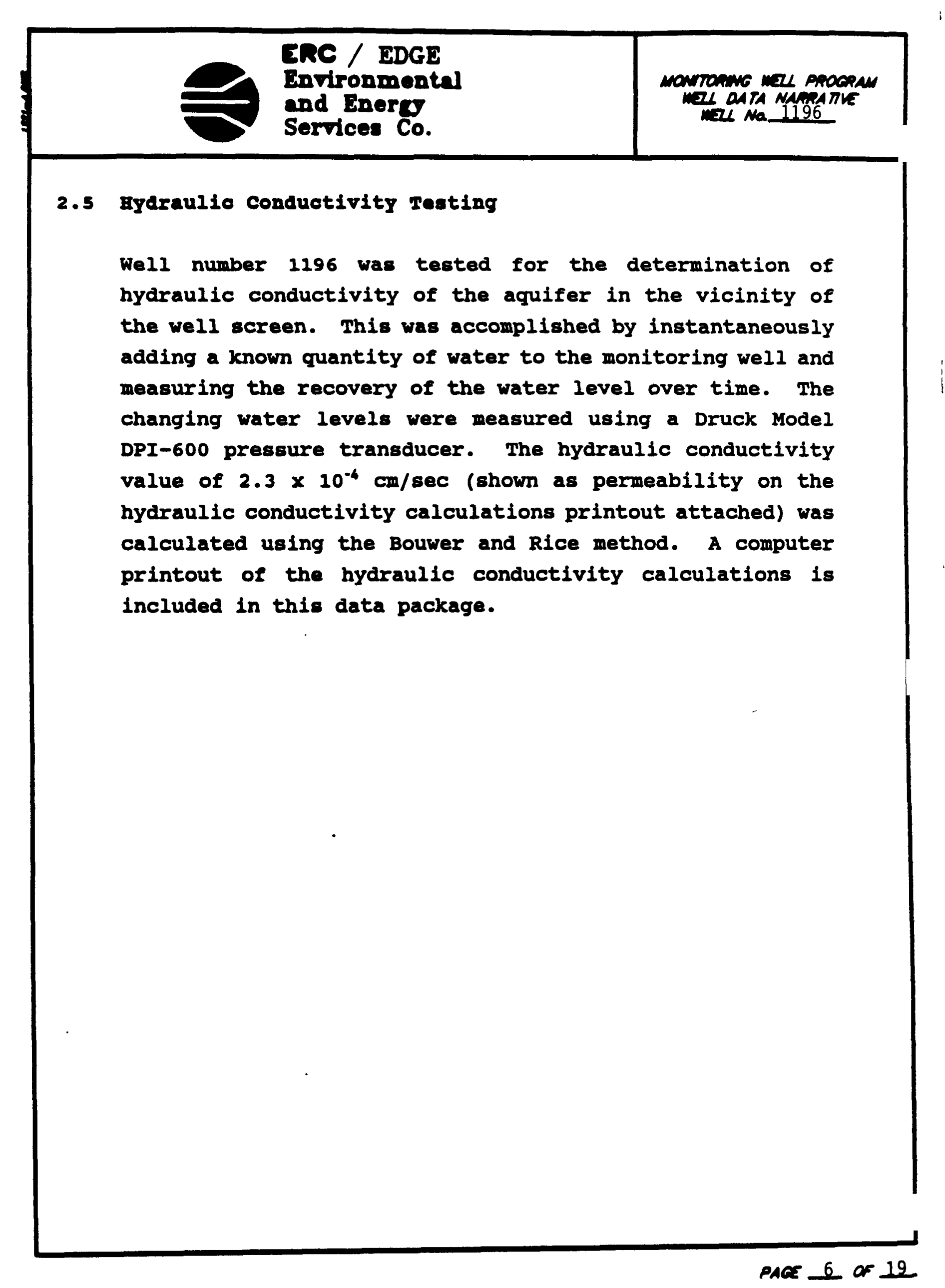




\section{PRE-DRILLING CHECKLIST FOR MONITORING WELLS}

\section{BRE-DRILUING TASKS}

1. EXCAVTION PERMIT OBTAINED

2. ALL EQUIPMENT HAS BEEN CLEANED BEFORE ORILLING.

30. SCREEN AND CASING HAVE BEEN WASHED, STEAMED, RINSED WTH DE-IONIZED OR DISTLLED WATER, RINSED WTH ISOPROPV ALCOHOL, WRAPPED WTH PROTECTIE COVERING AND STORED OFF THE GROUND.

36. PRE-PACKAGED SCREENS, CASING AND CENTRALIZERS UERE USED.

4. WORK AREA FOR SAMPLE EXAMINATTON COVERED WTH CLEAN POL YETHRENE.

5. CLEAN KNIVES, GLVES, SAMPLE JARS AND LABELS ON HAND.

6. POLYETHYENE COVER IN PLACE OVER HOLE.

7. AIR ROTARY COMPRESSED AIR SAMPLED.
COMPLANCE

DAIE NIIIALS

11-07-89 TOn

11-03-89 TJu

N / A

11-21-89 Tons

11-07-89 Tons

11-07-89 TD23

11-07-89 Tors

$11-21-89$

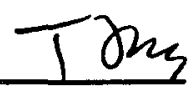

RESULIS: No detectable hydrocarbons under ultra violet light.

ADDITONAL NOTES/OBSERVATIONS:

OBSERVER SIGNATUREDATE $\frac{\text { AmmothCêm 11-21-89 }}{\text { Timothy Al Lee }}$ 


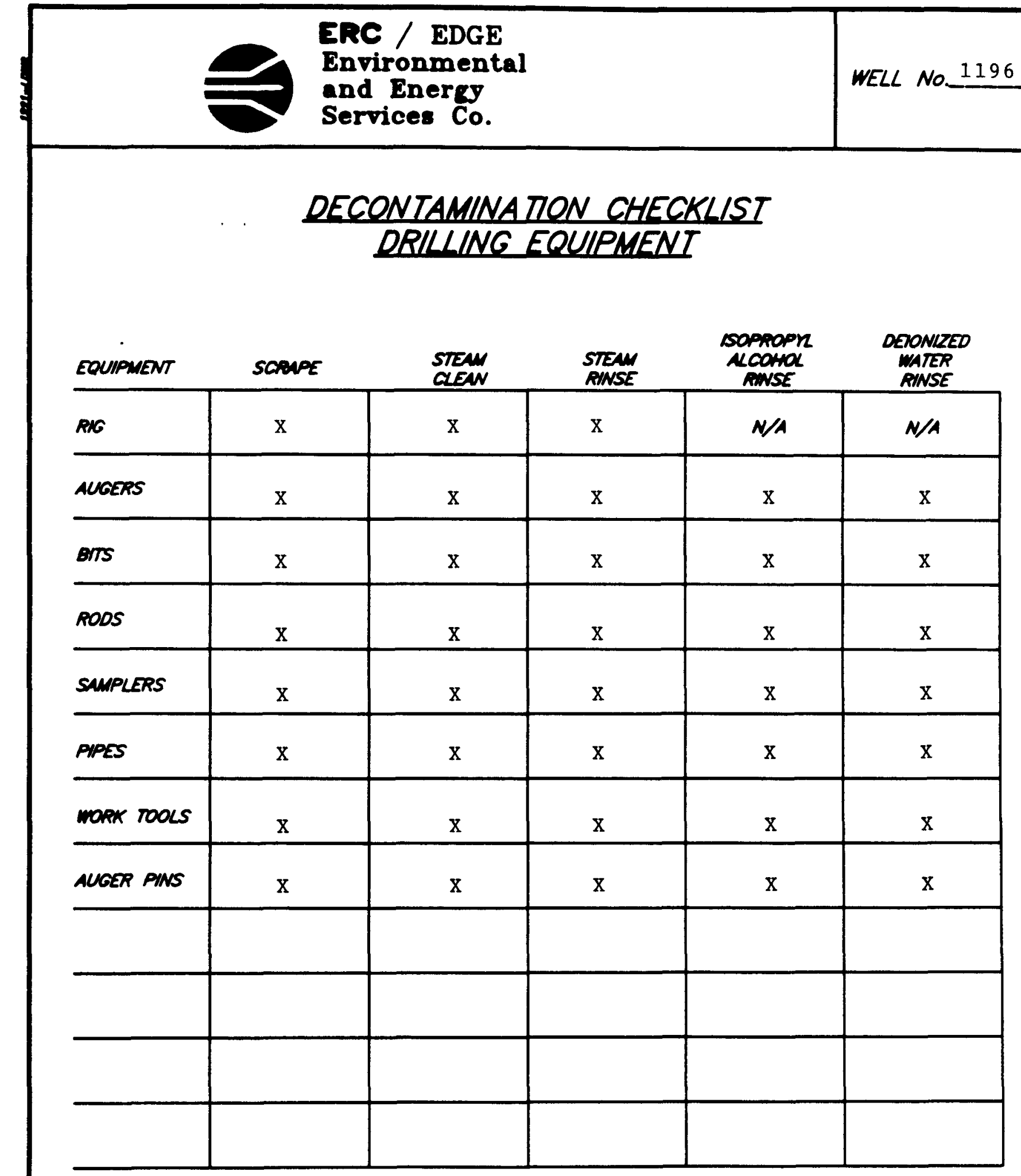

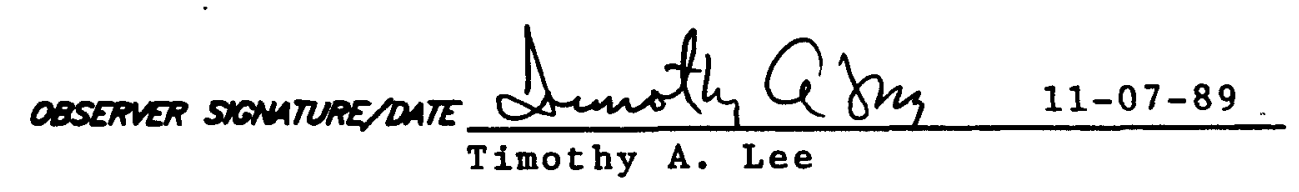


ORNL MONITORING WELL LOG

LOCA ION: WAG 17

ORILLER: George Akins

HELPER: Steve Kirk

DRILL: Schramm

TrPE DRILUNG: Split Spoon/Auger

NO. SAMPLES TAKEN:

CONTAINMENT TrPE: Plastic, Auger pan and Containment box

THICKNESS OF SOIL (REFUSAL DEPTH): $10.8^{\prime}$

DEPTH DRILLD IN ROCK: $7.2^{\prime}$

TOTAL DEPTH OF WEZL: $18.0^{\prime}$
PAGE 1 OF 2

DATE: START: $11-07-89$

FINISH: $11-21-89$

LOGGEO BY: Timothy A. Lee

HEALTH PHYSICSST: Randy Summers

LUBRICANT TYPE: Green stuff

TPPE:

\begin{tabular}{|c|c|c|c|c|}
\hline \multicolumn{2}{|c|}{$\begin{array}{l}\text { DEPTH } \\
\text { (FEED) }\end{array}$} & $\begin{array}{l}\text { SAMPLE } \\
\text { (NUMBER } \\
\text { INTERVAL) }\end{array}$ & $\begin{array}{c}\text { PERCENT } \\
\text { RECOVER } \\
\text { (SPUT SPOONS) }\end{array}$ & SOL/BEDROCK DESCRIPTION \\
\hline 0.0 & 0.4 & & $75 \%$ & Top soil and grass. \\
\hline 0.4 & 1.0 & & $75 \%$ & Gravel fill? Reddish brown clay and yellowish \\
\hline & & & & brown clay. \\
\hline 1.0 & 2.0 & & $75 \%$ & Clay, moderate yellowish brown, dense, damp, \\
\hline & & & & somewhat piastic. \\
\hline 2.0 & 3.0 & & $85 \%$ & Clay, dark yellowish orange, damp, stiff, \\
\hline & & & & dense; streaks of dark iron stains, mottled \\
\hline & & & & with light yellowish gray clay. \\
\hline 3.0 & 3.5 & & $85 \%$ & Clay, dark yellowish orange, slightly silty, \\
\hline & & & & mottled with dark brown iron stains, damp, \\
\hline & & & & stiff, dense. \\
\hline 3.5 & 4.0 & & $85 \%$ & Clay, dark yellowish orange, slightly silty, \\
\hline & & & & damp, stiff, dense; mottled with light \\
\hline & & & & yellowish gray clay. \\
\hline 4.0 & 6.0 & & $100 \%$ & Clay, dark yellowish orange, slightly silty, \\
\hline & & & & moist, dense, soft, mottled with 1 ight \\
\hline & & & & yellowish gray clay, scattered lenses of dark \\
\hline & & & & brown iron stains and scattered gravel sized \\
\hline & & & & unknown type rock. \\
\hline 6.0 & 7.9 & Bulk dens $i$ & Ey $100 \%$ & Clay, dark yellowish orange, slightly damp, \\
\hline & & $06.5^{\prime}-6.85^{\prime}$ & & dense, slightly silty, stiff bulk density \\
\hline
\end{tabular}

PACE 9 of 19 


\begin{tabular}{|c|c|c|c|c|}
\hline & & & $\begin{array}{l}\text { ERC / E } \\
\text { Environm } \\
\text { and Enes } \\
\text { Services }\end{array}$ & $\begin{array}{l}\text { DGE } \\
\text { ental } \\
\text { gy } \\
\text { Co. }\end{array}$ \\
\hline & ORNL & MONITORING & $G$ WELL LOG & PAGE 2 or 2 \\
\hline \begin{tabular}{|l} 
DEF \\
FEE \\
FROM \\
\end{tabular} & & $\begin{array}{l}\text { SAMPLE } \\
\text { (NAMBER \& } \\
\text { INTERVAL) }\end{array}$ & $\begin{array}{c}\text { PERCENT } \\
\text { RECOVERY } \\
\text { (SPLIT SPOONS) }\end{array}$ & SOL/BEDROCK DESCRIPTION \\
\hline 6.0 & 7.9 & & & (continued from page 1) sample 0 6.5'-6.85'; \\
\hline & & & & Bulk density $=2.08 \mathrm{grams} / \mathrm{cm}^{3}$ \\
\hline 7.9 & 8.0 & & $100 \%$ & Shale, limey, light olive gray, hard. \\
\hline 8.0 & 8.3 & & $80 \%$ & Shale, limey, light olive gray, hard. \\
\hline & 8.3 & & & Split spoon refusal. \\
\hline 8.3 & 9.0 & & & Limestone, shaley, light olive gray, hard. \\
\hline 9.0 & 9.3 & & & Limestone, shaley, light olive gray, hard. \\
\hline 9.3 & 10.8 & & & Limestone, shaley, olive gray, hard. \\
\hline & 10.8 & & & Auger refusal. \\
\hline 10.8 & 15.0 & & & $\star *$ Limestone, hard. \\
\hline 15.0 & 18.3 & & & Limestone, hard. \\
\hline & 18.3 & & & Total Depth \\
\hline & & & & \\
\hline & & & & *No soil samples taken due to the tests run \\
\hline & & & & by Bechte1. \\
\hline & & & & \\
\hline & & & & **No detailed lithologic description available \\
\hline & & & & from $10.8^{\prime}$ due to the use of containment box. \\
\hline & & & & \\
\hline & & & & \\
\hline & & & & \\
\hline & & & & \\
\hline & & & & \\
\hline & & & & \\
\hline & & & & \\
\hline & & & & \\
\hline & & & & \\
\hline & & & & \\
\hline & & & & \\
\hline & & & & \\
\hline & & & & \\
\hline & & & & \\
\hline & & & & \\
\hline
\end{tabular}




\section{MONITORING WELL MATERIALS CERTIICATION}

\section{ITEM/MA TERIAL} DATE USED BATCH NUMBES

SAND

\begin{tabular}{c|c|c}
\multicolumn{2}{c}{ DAIE USED } & BATCH NUMBES \\
\cline { 2 - 3 } & $11-21-89$ & 1 \\
\cline { 2 - 3 } & & \\
\cline { 2 - 3 } & $11-21-89$ & 1 \\
\cline { 2 - 3 } & & \\
\hline $\left.\begin{array}{c}Y E S \\
\text { NO }\end{array}\right)$ & $11-21-89$ & 2 \\
\hline $\left.\begin{array}{c}\text { YES } \\
\text { NO }\end{array}\right)$ & $11-21-89$ & 2 \\
\hline
\end{tabular}

\section{BENTONITE}

\begin{tabular}{|c|c|c|c|}
\hline STAINLESS STEEL SCREEN & (PREPACKACED $\begin{array}{ll}\text { MES } \\
\text { NO }\end{array}$ & $11-21-89$ & 2 \\
\hline STAINLESS STEER CASNG & $\left(\begin{array}{lll}\text { (PREPACKACED } & \text { YES } \\
\text { NO }\end{array}\right)$ & $11-21-89$ & 2 \\
\hline STAMLESS STEER CENTRALIERS & 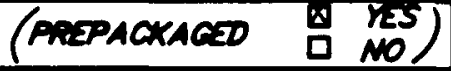 & $11-21-89$ & 2 \\
\hline STANLESS STERL CAPS & (PRDPACKAGED $\left.\begin{array}{cc}\text { MES } \\
\text { NO }\end{array}\right)$ & $11-21-89$ & 2 \\
\hline MONTORMG MELL PLMP & (PREPACKACED O $\left.\begin{array}{cc}\text { YES } \\
\text { NO }\end{array}\right)$ & $4-18-90$ & 5 \\
\hline Grout & & $11-21-89$ & 3 \\
\hline \multicolumn{4}{|l|}{ WEL COVERS } \\
\hline SURFACE CASWG & Diverter Casing & $11-07-89$ & 2 \\
\hline
\end{tabular}

COMMENTS:

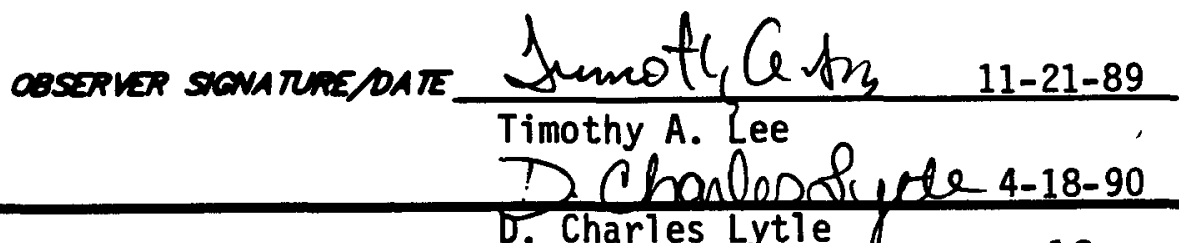




\section{POST-MELL COMPLETION CHECKLIST}

\section{POST-WELL COMPLETON TASKS}

1. MUD SCRAPED FROM AUGERS SMMPLERS, AND NL OTHER EQUIPMENT.

2. ALL WUO FRON RNG ANO EOUPIENT SCRAPINGS ANO CUTINOS OSSPOSED OF IN ACCORDANCE WTH DHE SPECIFCA IION PROWOED.

3 WEL OEVEZOREO IN ACCOROANCE WIH THE SPECARCA ION" PROMOED AND OETAKS OF THE DEVELOPUENT ACTUTH RECOROED.

4. DPULNG STT PROPERLY QLEAND UP NTER complemon of Mel installinow.
COMPLIANCE

DATE INITALS

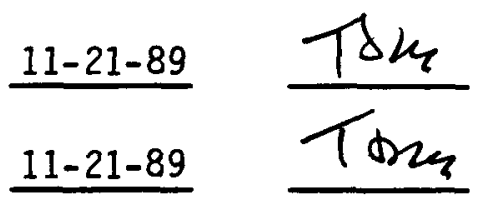

$4-18-90$

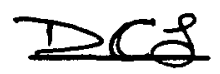

11-21-89

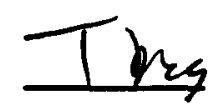

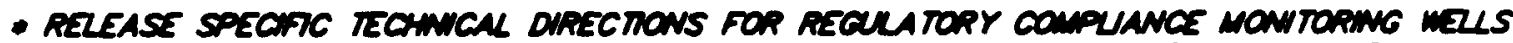
PHASE l, OAK ADOCE NATIONAL LABORATOPY, OAK REDES M.Q K-4147, APARK 1907.

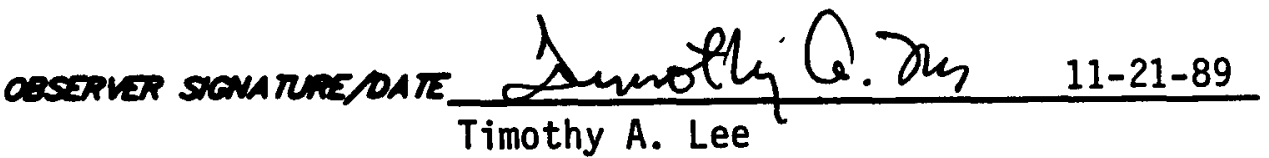

$\frac{\text { D. Charlepopyte } \quad 4-18-89}{\text { D. Charles Lytie }}$


ERC / EDGE

Environmental

and Eneres

Services Co.

\section{MONITORING WELL \\ DEVELOPMENT FORM}

DEVELOPMENT DETAILS

METHOO OF

DEVELOMENT: Surging and Pumping

DEVELOPNENT

BEGAN DATF:

$3-28-90$

TME:

DEVEZ OPMENT

ENONG DATE:

4-18-90

DEVZOPMENT

OBSJRVED BY. D. Charles Lytle

ane neze voume: 6.8 cresons

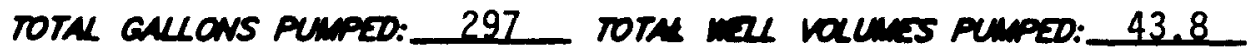

WTIN PH: 7.8 FWN PH: 7.8

WUTA CONOUCTUTH (US): 750 FNAL CONOUCTVTr (us): 830

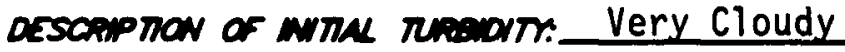

oescomprow of FwN neevorry. Semi Clear

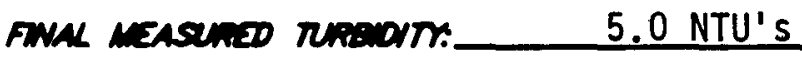

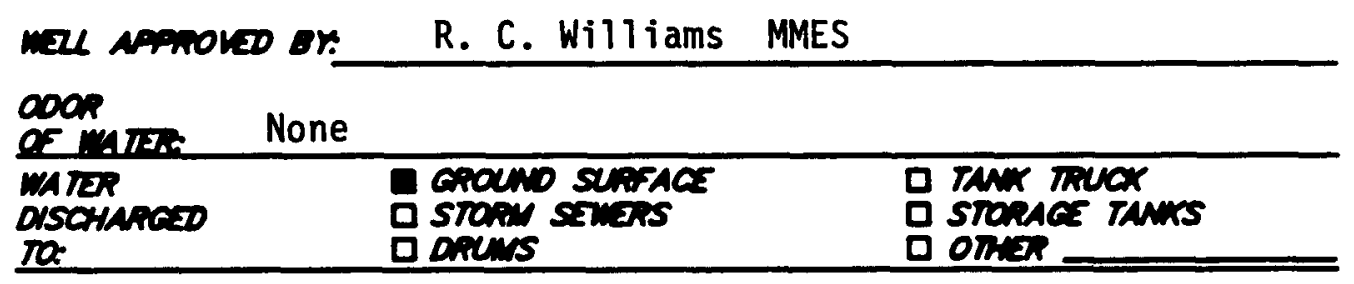

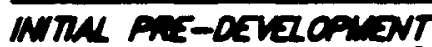

mase ospht $\quad 3.6$ feet from ground surface.

OEVELOPMENT OBSERVATONS

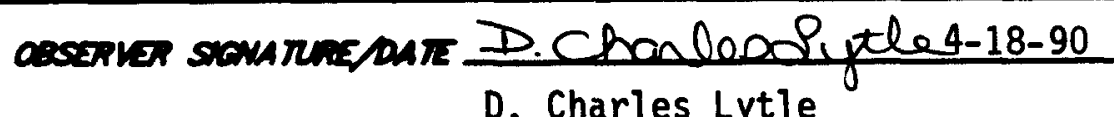




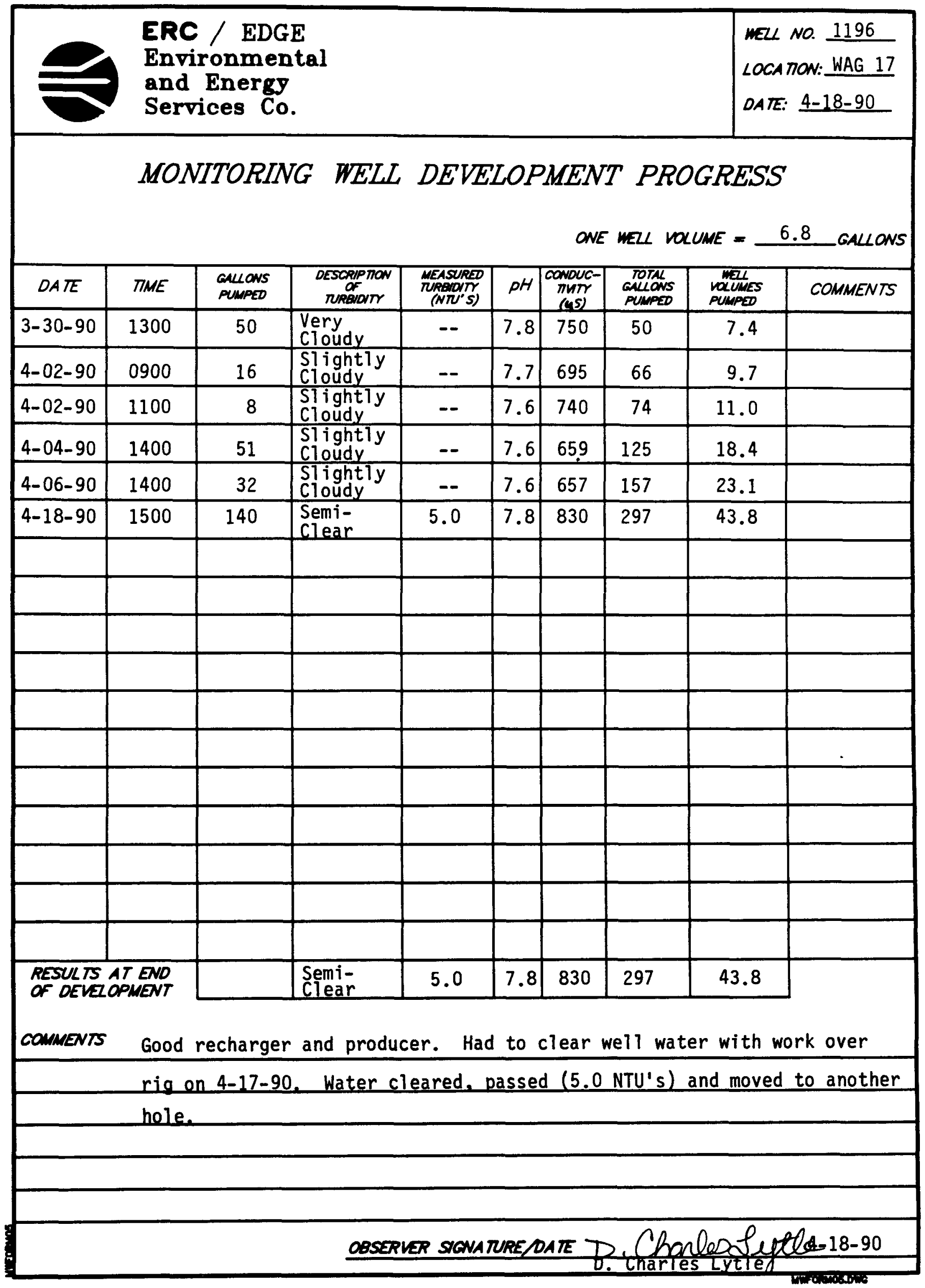




\section{HYORAULIC CONDUCTIVTY CALCULATIONS}

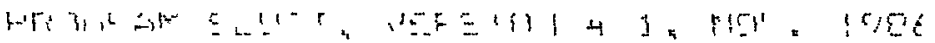

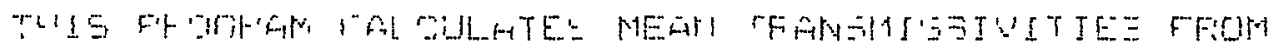

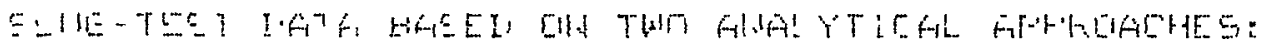

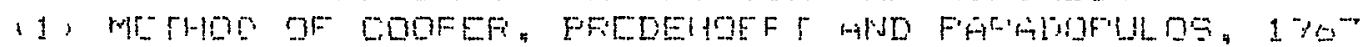

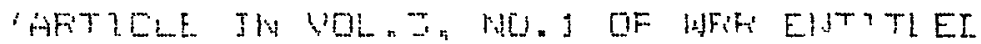

"RESFOISE GE A FUNTTE DIAMETEF WLLL TO AU TNSTAMTAREOUS CHAFEE OF WFTEF:";

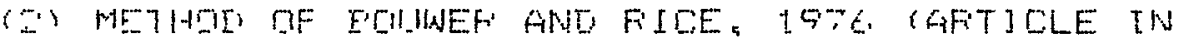

UOL: 1 ; NO, $:$ OF WFE ENTTTLED

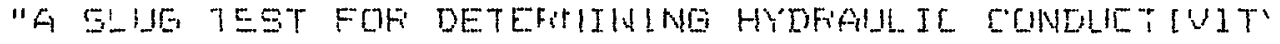
OF IWIOUIFINEN AOUJFEFS WITH COHFLETELY GF FARTIAL: $\checkmark$ FEIUETFIAT INS WELLS"'

WELL NO.: $11 \%$

DATE QF TEST: $: 10: 90$

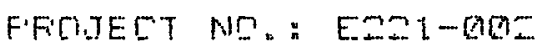

CLLENT: MMES

GITE LOCATION: WAG 17

EDGE, INC. FJELD INYESTIGATOF: ERLICE MCMASTEF:

\section{INPUT DATA AFE:}

JNNEF CASING DIAMETEF $=2 . D O$ INCHES

INNEF: SCREEN OF OFEN-HOLE DIAMETEF: $=2.00$ INCHES

DIAMETEF OF DFILLED HDLE $=8.00$ INCHES

LENGTH OF SCFEEN OF INTAIE FORTION $=10.00$ FEET

DEFTH FFOM STATIC LEVEL TO EOTTOM OF SCFEEN = 12.00 FEET

THICH NESS QF SATIJFATED AQUIFER ZONE $=10.00 \mathrm{FEET}$

DEFTH TD STATIC WATEF LEVEL BELOW REF. FOINT $=1$. DD FEET

ESTTMATED FOFDSITY OF GFAVEL FACY $=.20$

FALLING-HEAD INIEX $=1$ ("1" IF FALLING, "Q" IF FIISING)

NUMEEF OF DEFTH-TIME DATA POINTS $=17$

HO WAS COMFUTED FROM INTEFCEFT OF FLOT OF LOG (H) VS: TIME

\section{SULCESSIVE COMFUTED \\ VALUES FOF HO \\ (FEET)}




\section{HYORAULIC CONDUCTIVTY CALCULATIONS}

7 IME

:SETIIII

10.00

20.00

․․ 0.00

40.00

50.00

60.90

$75 \cdot 60$

90.00

105.00

120.00

150.00

180.00

240.00

$\therefore 00.00$

.60 .00

420.00

480.00
DEFTH TO WHTEFF SFEEY

$=9.0$

$=420$

$\because 000$

2.9.0

‥500

$\therefore=90$

$\therefore .190$

2.010

1. 870

1.750

$1=600$

1. 490

1. .60

1. $=30$

1.160

1.040

1. 010
HEA

IFEET.

$=0.0 .6$

$=4.8$

$=080$

1. 920

1. 600

1. .90

1.100

1. 010

.

.750

.000

470

. 50

$\therefore$.

.150

.040

.010

METHDD OF EOLWEF AND FIIEE

COMPUTED FESUL.TS USING DJAMETEF DF DFILLED HOLE:

FEFMEAEILITY $=7.55 E-06 \mathrm{FT} /$ SECOND $=2.50 \mathrm{O}-04 \mathrm{CM} / \mathrm{SEC}$

TFANSMISSIUITY $=7.55 E-05 \mathrm{FT} * 2 / S E C O N D$

COMPUTED FESULTS USING DIAMETEF OF CASING AND SCFEEN:

FEFIMEABILITY $=1.08 E-05 \mathrm{FT} / \mathrm{SECOND}=5.30 \mathrm{E}-04 \mathrm{CM} / \mathrm{SEC}$

TFANSMISSIVITY $=1$. DEE-D4 FT**I/SECOND 


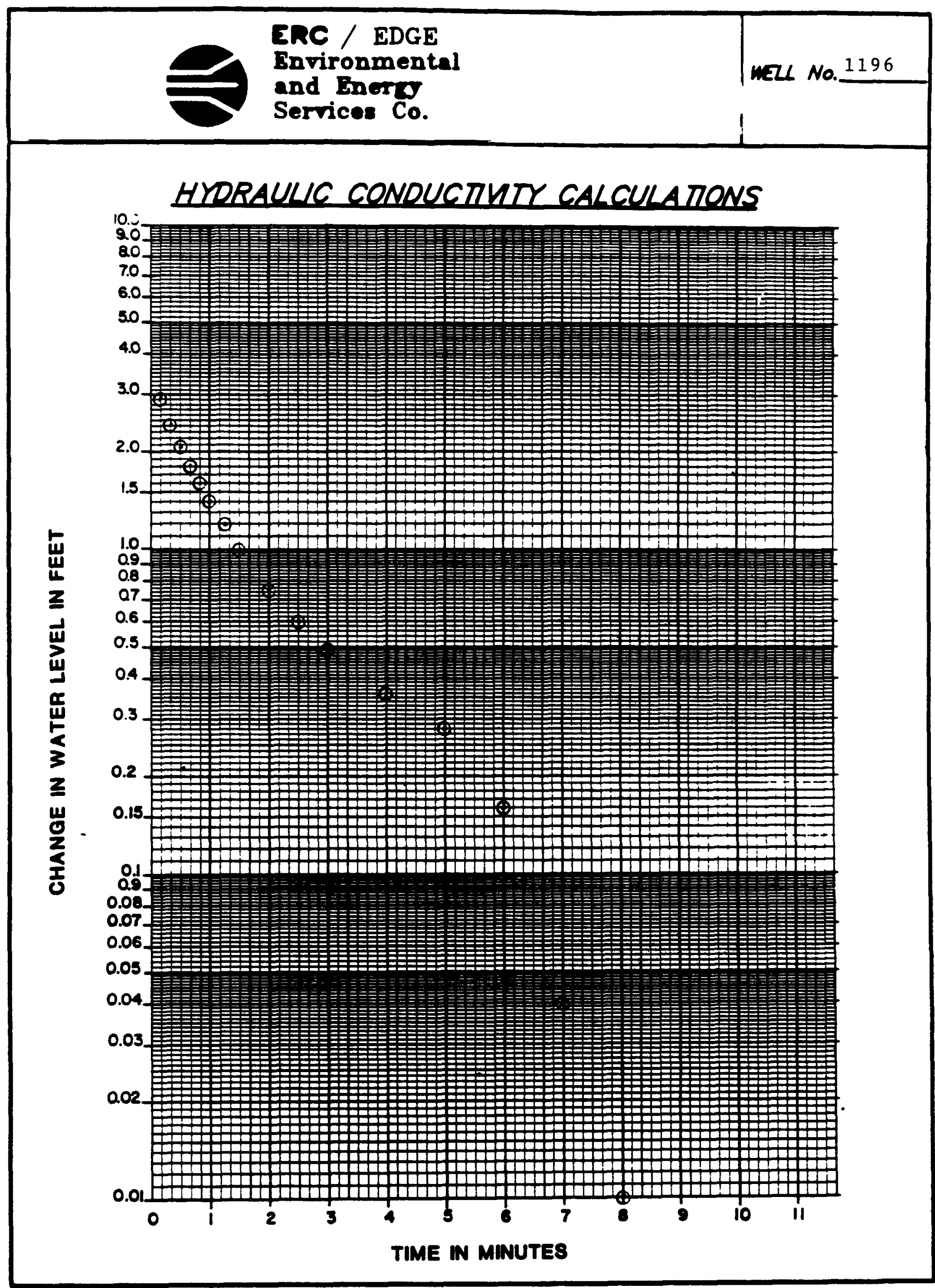

PAar 18 of 19 


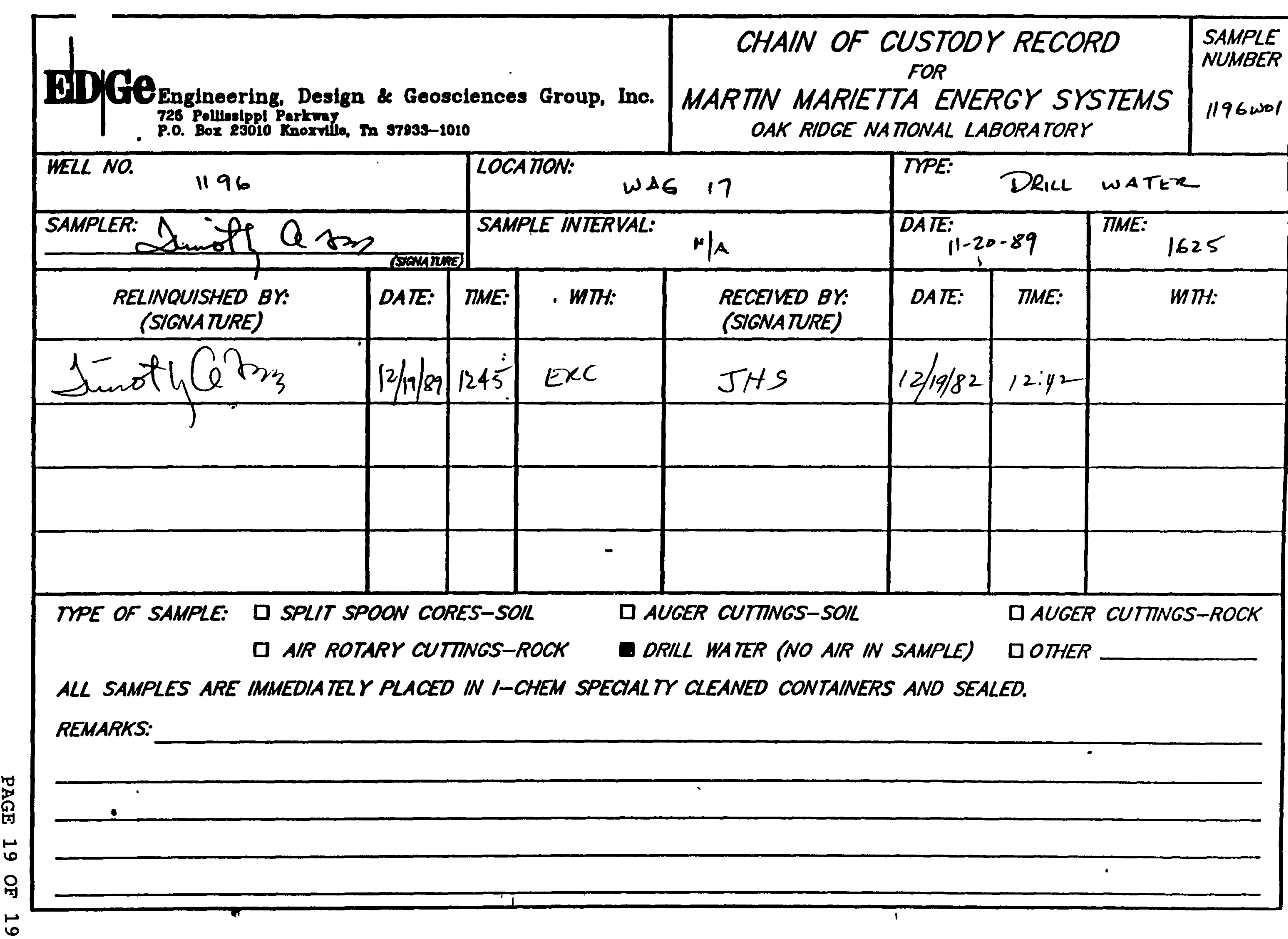


i 
1.0 General Information

1.1 Well Location

Monitoring well number 1197 is located in WAG 17. It is along the east side of WAG 17 approximately 125 feet north of Bldg. 7033. The location is shown on ORNL drawing number C3E20004A075. Survey coordinates for this well are N $21,732.6979$, E $37,633.9438$ (X-10 grid) or latitude $35^{\circ}-$ $56^{\prime}-09.66^{\prime \prime}$ and longltude $84^{\circ}-17^{\prime}-52.24^{\prime \prime}$. Coordinate data were provided by Martin Marietta Energy Systems. The method used for conversion from $x-10$ grid to TennesseeLambert state plane Coordinates came from the publication "Tennessee Valley Authority Data Services Branch and Mapping Servicess Branch, Oak Ridge, Tennessee, DOE Plant Control, November 6, 1985, Field Book: Ess-3115, pp. 120." The latitude and longitude were calculated by Adams Craft Herz Walker Engineering, Inc., using methods from the U.S. Coast and Geodetic Survey Publication 62-4, "State Plane Coordinates by Automatic Data Processing."

\subsection{Dri111ng Informition}

Well number 1197 was drilled by Geotek Engineering Company . A Schramm Rotadrill rig was used to drill this boring for monitor well installation under the operation of George Akins with the assistance of steve Kirk and James Shelton. Drilling commenced on $11 / 7 / 89$ and was finished on 11/28/89. Paragraph 2.4.1 includes a detailed discussion of the well Installation and a well schematic is included on the well installation/ completion form. A synopsis of the drilling activity follows. This information was typed directly from field notes and was edited only when necessary for clarification. 
11-7-89: The rig was moved to the staked location and set upon plastic. split spoon samples were taken from the surface to refusal at 4.8 feet. The boring was reamed and $151 / 4$ inch diverter casing was grouted in place at 3.5 feet. The rig was moved from the location.

11-21-89: The rig was mobilized to the location and set up on plastic. The boring was deepened from 4.8 feet to 10.9 feet with a $141 / 2$ inch air rotary tricone bit using a containment box.

11-22-89: Set 10.9 feet of $103 / 4$ inch decontaminated steel surface casing and grouted to surface with 4 sacks of cement.

11-27-89: The boring was deepened to 48.8 feet with a 7 $7 / 8$ inch air rotary tricone bit using the containment box.

11-28-89: Had 28.0 feet of water in hole. Installed 4" stainless steel casing and screen with sand pack and bentonite seal. Grouted annular space with 5 eacks cement.

This well was logged by the EDGe Group of ERC Environmental and Energy Services Co., Inc., hydrogeologiet Timothy A. Lee. All well construction materials and supplies were from Martin Marietta Energy Systams approved batches. The batch origin of individual items 18 shown on the included Monitoring Well Materials certification form. 
2.0 Technionl Information

2.1 Decontamination Procedures

The drilling rig, down hole tools, surface casing, stainless steel screen, stainless steel casing, centralizers, and stainless steel silt trap underwent the cleaning decontamination procedures outlined in the drilling specifications (Release specific Technical Directions for Regulatory Compliance Monitoring Wells Phase 1, Oak Ridge National Laboratory, Oak Ridge, W.0. K-4147, April 1987, pgs. 2-4). A checklist of the cleaned materials is included with this data package.

\subsection{9}

WAG 17 encompasses approximately 23 acres in Bethel Valley, which is in the Valley and Ridge Physiographic Province of East Tennessee. WAG 17 is underlain by the Middle Ordovician Chickamauga Group consisting mainly of limestone and siltstone. The chickamauga Group consists of eight units, designated by letters A through H (Stockdale, 1951). WAG 17 is underlain by units $\mathrm{E}, \mathrm{F}, \mathrm{G}$ and $a$ portion of $H$. These unite consist of thin bedded nodular limestone with clay and shale partings. Portions of units $H$ and $F$ consist of calcareous siltstone alternating with beds of olive gray to maroon shale. The regional strike is $56^{\circ}$ northeast and has a moderate dip of $30^{\circ}$ to $40^{\circ}$ southeast.

\section{3 sample collection}

Soll samples were collected during drilling by Bechtel National, Inc., the Remedial Investigation/Feasibility study subcontractor. A drill water sample was collected 
from the water pump on the drill rig on 11-27-89. Analytical results for the Schramm drill water sample can be obtained from the Remedial Action Program data base at ORNL. The analytical results for the soil samples can be obtained from Bechtel.

A bulk density soil sample was not collected.

The Schramm Rig compressed air was sampled with a cloth filter inserted between drill rods on 11-27-89. The sample was examined with an ultraviolet light for the presence of hydrocarbons. The filter showed no evidence of hydrocarbons.

\subsection{Installation and Development}

\subsubsection{Installation}

This was a type B well. A 22.0-inch diameter boring was augered from ground surface to 3.5 feet. A 15 1/4-inch diverter casing was installed from surface to 3.5 feet below ground surface and grouted in place. A $141 / 2-$ inch diameter boring was augered from 3.5 feet to 4.8 feet (auger refusal). The boring was then extended past the refusal depth with a 14 1/2-inch air rotary tricone roller bit from 4.8 feet to 10.9 feet. A 10 3/4-inch diameter string of decontaminated steel surface casing was installed from 0.0 leat to 10.9 feet, sealed with a 2.0-foot bentonite pellet layer from 8.9 feet to 10.9 feet, and tremie-grouted in place. The surface casing minimizes potential cross contamination between the regolith and bedrock water bearing zones. After the surface casing was installed, the air rotary method was used to drill an 8inch diameter boring to a total depth of 49.0 feet. A 4- 
inch diameter stainless steel screen with threaded bottom cap was installed from 48.8 feet to 33.6 feet. A 4-inch diameter stainless steel casing was installed from the top of the screen at 33.6 feet and extended 2.13 feet above ground surface. A sandpack was then tremied into the annular space from 31.1 to 48.8 feet, with a 3.5-foot bentonite pellet seal poured into the annular space above the sandpack from 27.6 to 31.1 feet. The annular space from the top of the bentonite seal to the surface was tremie-grouted with a cement/bentonite slurry. A detailed schematic of the well is included on the well installation/completion form.

\section{4 .2 Well Development}

Well number 1197 was developed to remove drill cuttings, silt, and other fines. The monitoring well was developed using a Geoguard pump with an air compressor. All pumps were cleaned prior to use according to specified cleaning procedures (see Paragraph 2.1). The well was developed until a measured total of 147 gallons of water had been evacuated and the clarity of the discharge water was approved by the company representa-tive. The final turbidity value measured at completion was 3.0 NTU's. A development form showing the exact method of development and other pertinent data is appended.

\subsubsection{Instalintion of Dedionted Monitoring We11 Pump}

After the well was developed, a Geoguard Model No. 5614 dedicated monitoring well pump was installed on 4-2-90 at a depth of 45.4 feet below ground surface. These pumps are decontaminated at American sigma and are sent prepackaged. A copy of the pump certification is kept on file at ORNL. 


\subsection{Bydraulie Conductivity Testing}

Well number 1197 was tested for the determination of hydraulic conductivity of the aquifer in the vicinity of the well screen. This was accomplished by instantaneously adding a known quantity of water to the monitoring well and measuring the recovery of the water level over time. The changing water levels were measured using a Druck Model DPI-600 pressure transducer. The hydraulic conductivity value of $1.27 \times 10^{-5} \mathrm{~cm} /$ second (shown as permeability on the hydraulic conductivity calculations printout attached) was calculated using the Bouwer and Rice method. A computer printout of the hydraulic conductivity calculations is included in this data package. 


\section{PRE-DRILLING CHECKLIST FOR MONITORING WELLS}

\section{RRE-DRILUNG TASKS}

1. EXCAVTON PERMIT OBTAINED

2. ALL EQUIPMENT HAS BEEN CLEANED BEFORE DRILLING.

30. SCREEN ANO CASING HAVE BEEN WASHED, STEAMED, RINSED WIH DE-IONIIED OR DISTLLED WATER, RINSED WTH ISOPROPV ALCOHOL, WRAPPED WTH PROTECTIVE COVERING AND STORED OFF THE GROUND.

36. PRE-PACKAGED SCREENS, CASING AND CENTRALIZERS WERE USED.

4. WORK AREA FOR SAMPLE EXAMINATION COVERED WTH CLEAN POL YETHRENE.

5. CLEAN KNIVES, GLOVES, SAMPLE JARS AND LABELS ON HAND.

6. POL YETHYENE COVER IN PLACE OVER HOLE.

7. ARR ROTARY COMPRESSED AIR SAMPLED.
COMPLANCE

\begin{tabular}{ll}
$\frac{D A I E}{11-07-89}$ & $\frac{\text { NIDALS }}{\angle A B}$ \\
$\frac{11-03-89}{11-21-89}$ & $C A B$ \\
$N / A$ & \\
\hline
\end{tabular}

$11-28-89$

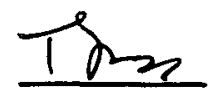

$11-21-89$

11-07-89 CAB

$11-21-89$

$\underline{11-07-89}$

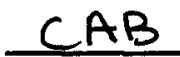

$11-28-89$

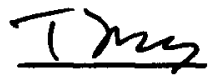

$11-27-89$

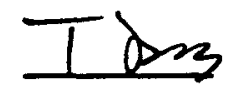

RESUL TS:

ADDITIONAL NOTES/OBSERVA MONS:

C. delusu-Baile 11-07-89

OBSERVER SYGNATURE/OATE

$\frac{\text { C. AmotyC ins 11-21-89 }}{\text { Timothy A. Lee }}$


DECONTAMINATION CHECKLIST DRILLING EQUIPMENT

\begin{tabular}{|c|c|c|c|c|c|}
\hline EQUIPMENT & SCOAPE & $\begin{array}{l}\text { STEW } \\
\text { QLEW }\end{array}$ & $\begin{array}{l}\text { STEN } \\
\text { RINSE }\end{array}$ & $\begin{array}{l}\text { SOPAOPR } \\
\text { LCOHOL } \\
\text { RWNSE }\end{array}$ & $\begin{array}{c}\text { DEIONIZED } \\
\text { WATER } \\
\text { RINSE }\end{array}$ \\
\hline RNG & $x$ & $x$ & $x$ & $N / A$ & $N / A$ \\
\hline AUGERS & $x$ & $x$ & $x$ & $x$ & $x$ \\
\hline Bnts & $x$ & $x$ & $x$ & $x$ & $x$ \\
\hline RODS & $x$ & $x$ & $x$ & $x$ & $x$ \\
\hline SMPLERS & $x$ & $x$ & $x$ & $x$ & $x$ \\
\hline PIPES & $x$ & $x$ & $x$ & $x$ & $x$ \\
\hline WORK TOOLS & $x$ & $x$ & $x$ & $x$ & $x$ \\
\hline ALGER PINS & $x$ & $x$ & $x$ & $x$ & $x$ \\
\hline & & & & & \\
\hline & & & & & \\
\hline & & & & & \\
\hline & & & & & \\
\hline
\end{tabular}

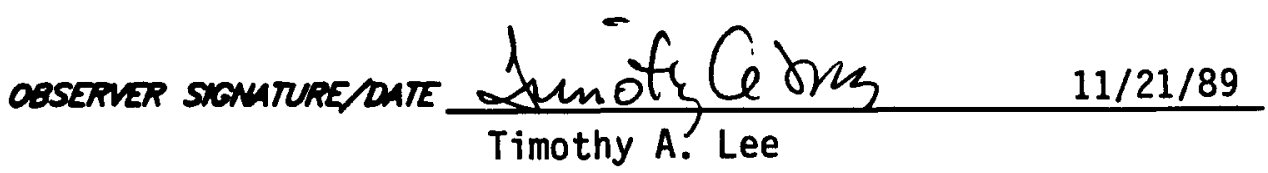




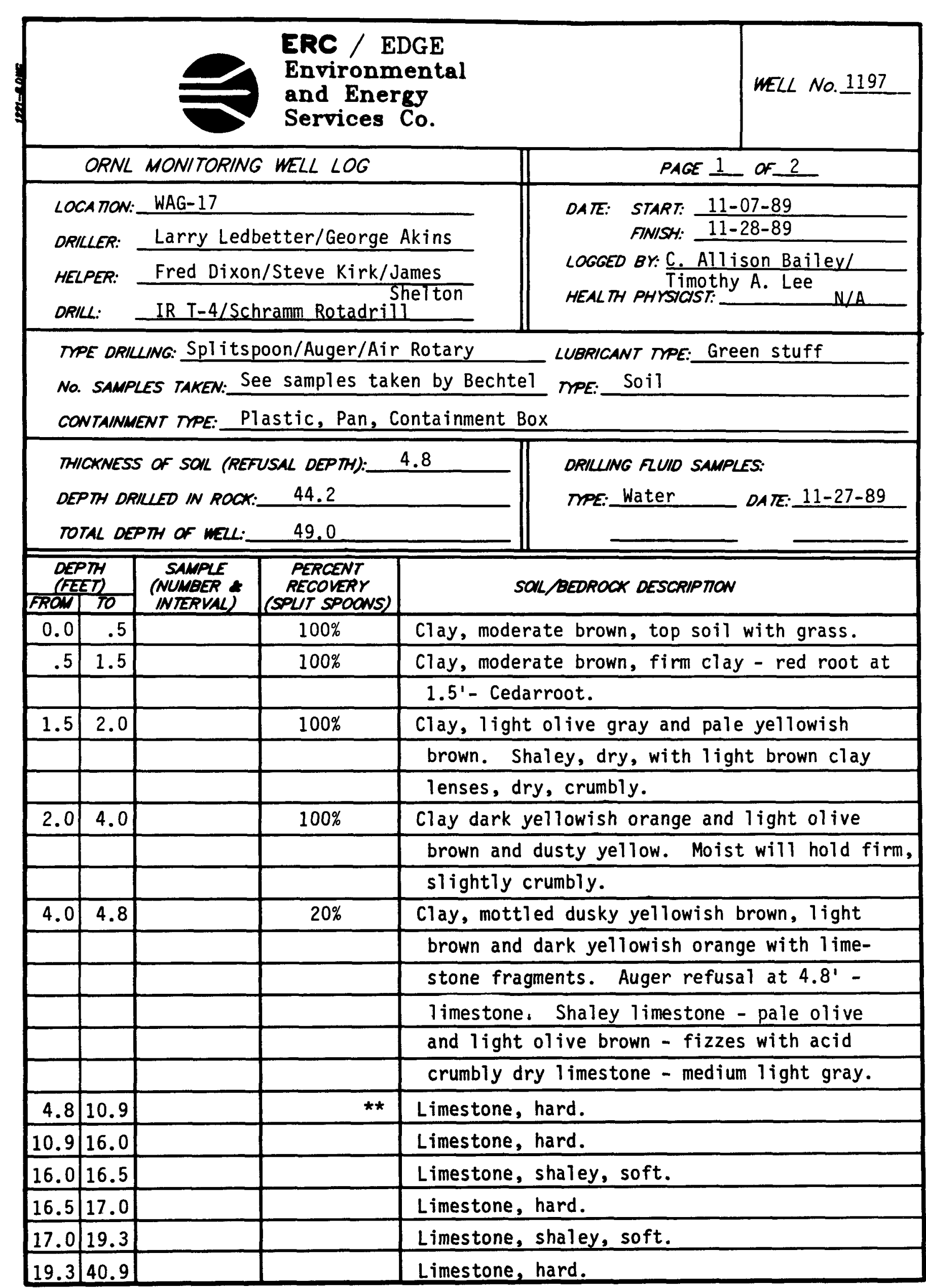




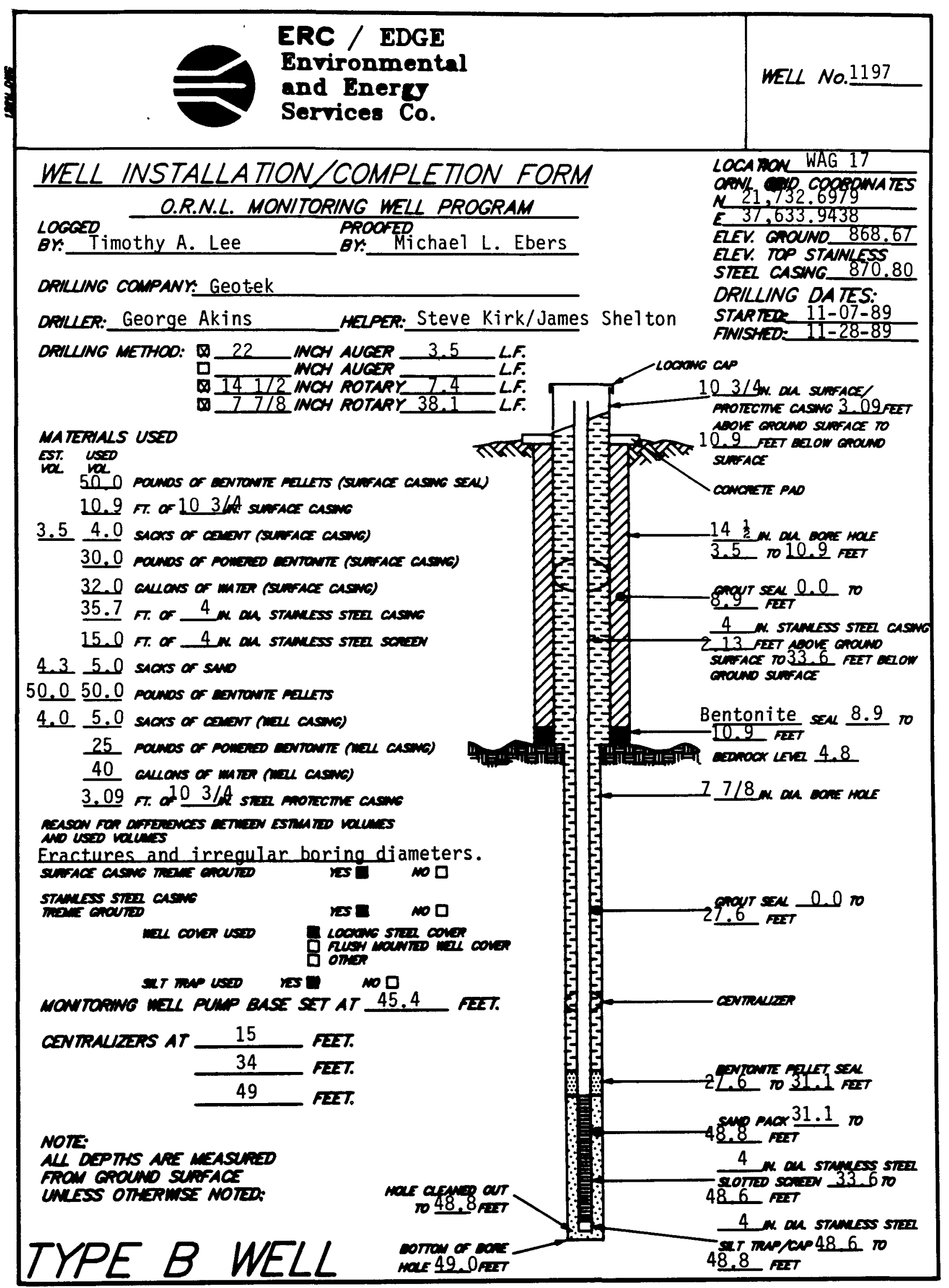

PACE 11 or 20 
ERC / EDGE

Environmental

WELL NO._1197

and Energy

Services Co.

DATE: $11-28-89$

MONITORING WELL MATERIALS

CERTIFICA TION

ITEM MA TERIAL

DATE USED BATCH NUMBER

SAND

BENTONITE

Pellets

Powder

STAINLESS STEEL SCREEN

STANLESS STEER CASWG

STANLESS STEER CENTRALIZERS

STANLESS STEER CAPS

MONITORANG MELL PUMP

GPOUT

Surface

SS Casing

WELL COVERS

SURFACE GASWG

(PREPACXAGED

(PREPACKAEED

(PREPACKACEDD

(PREPACKACED

D

11-28-89

Yes)

no)

4-02-90

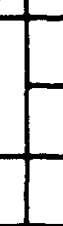

$11-21-89$

$11-28-89$

3

COMMENTS:

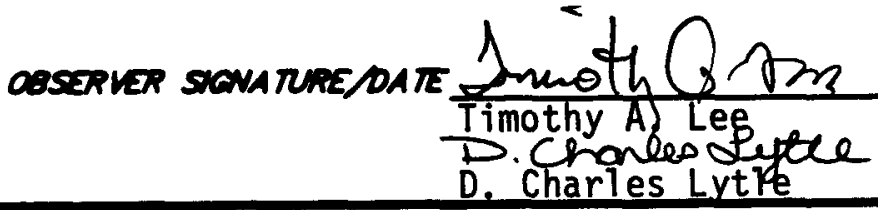

$11-28-89$

D. Charles Lyt te

4- 02-90

PACE 12 or 20 


\section{POST-WELL COMPLETION \\ CHECKLIST}

\section{POST-WELL COMPLETION TASKS}

COMPLIANCE

DATE INITALS

1. WUD SCRAPED FRON AUCERS SAMPLERS ANO ALI

11-28-89 The

2. ALL WUD FROM RIG ANO EOUPMENT SCRAPWOS ANO CUTITNOS DISPOSED or in ACCOROANCE WTH THE SPECARCA IION PROWOED.

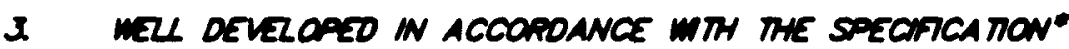

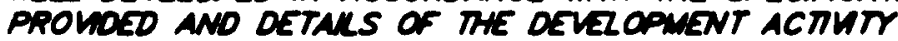
RECORDED.

4. DRULANG STE PROPERY CLEANDO UP AFTER completion of nal WSTALLINON.

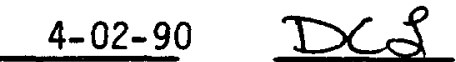

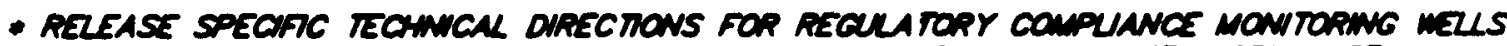

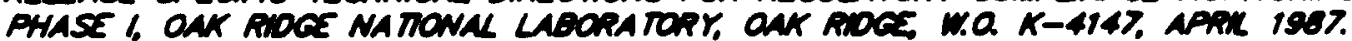

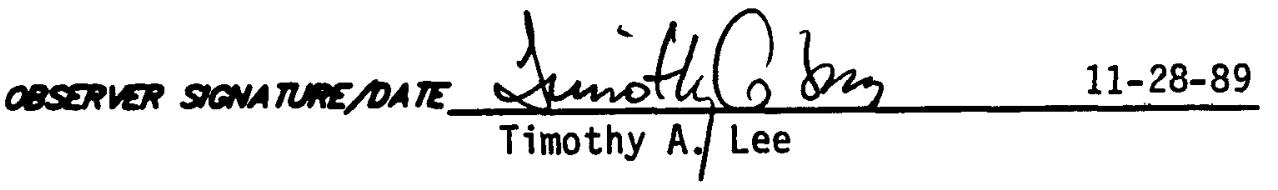

$$
\begin{aligned}
& \text { D.Chanlosolutte 4-02-90 } \\
& \text { D. Charles Lytle }
\end{aligned}
$$


ERC / EDGE

Environmental

and Eneres

Services Co.

\section{MONITORING WELL \\ DEVELOPMENT FORM}

DEVELOPMENT DETAILS

NETHOD of

DEVEQRevENT: Surging and Pumping

DEVELOPENT

BEGAN DATE.

$3 / 28 / 90$

TME:

DERZZOPNENT

ENDWE DATE: 4/02/90

DEVZLOPNENT

QSSERVE Br. D. Charles Lytle

ane wer volume: 35.1 anews

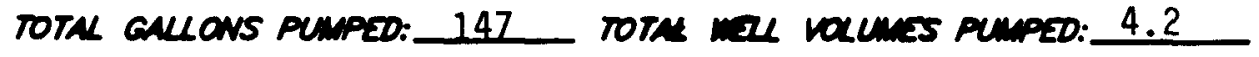

WWTML PH: 7.6 TNAL PH: 7.3

WHAL CONOUCTUTH (US): 781 FNAL CONOUCTUTY (wS): 734

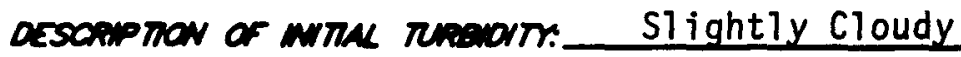

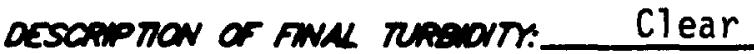

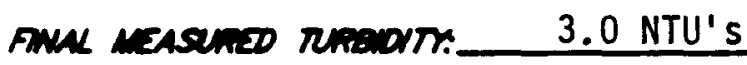

mel Ammoves or. R. C. Williams MMES

OoOp

af mardane None

MATR a GPOND senaface

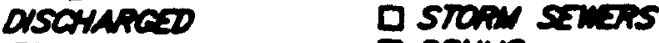

To.

a areurs

D TAN TRUar

D STORAGE TAMrs

0 ornis

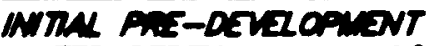

MATS DJPT.

13.6 feet from ground surface.

\section{DEVEL OPMINT OBSERVATIONS}

ascerver sevarnespate D. Chanlenolutele

D. Charles LytTe 4/02/90

PACE 14 or 20 


\begin{tabular}{|c|c|c|c|c|c|c|c|c|c|}
\hline L & \multicolumn{3}{|c|}{$\begin{array}{l}\text { ERC / EDGE } \\
\text { Environmental } \\
\text { and Energy } \\
\text { Services Co. }\end{array}$} & & & & & \multicolumn{2}{|c|}{$\begin{array}{l}\text { WEL NO. } \frac{1197}{\text { WAG } 17} \\
\text { LOCA TON: } \frac{17}{\text { DATE: } 3 / 28 / 90}\end{array}$} \\
\hline & \multicolumn{9}{|c|}{ MONITORING WELL DEVELOPMENT PROGRESS } \\
\hline & \multicolumn{9}{|c|}{ ONE WEL VOLUME $=35,1$ GALLONS } \\
\hline DATE & TME & $\begin{array}{l}\text { Gulaws } \\
\text { PUMPED }\end{array}$ & 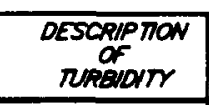 & 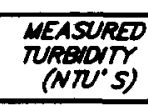 & $\rho H$ & $\begin{array}{c}\text { conouc- } \\
\text { nury } \\
(\mu S)\end{array}$ & $\begin{array}{l}\text { ToTh } \\
\text { Thlows } \\
\text { Puimped }\end{array}$ & $\begin{array}{l}\text { MeI } \\
\text { volumes } \\
\text { PUWPeD }\end{array}$ & COMMENTS \\
\hline $3-30-90$ & 1300 & 131 & $\begin{array}{l}\text { Slightly } \\
\text { Cloudy }\end{array}$ & -- & 7.6 & 781 & 131 & 3.7 & \\
\hline $4-02-90$ & 0900 & 16 & Clear & 3.0 & 7.3 & 734 & 147 & 4.2 & \\
\hline & & & & & & & & & \\
\hline & & & & & & & & & \\
\hline & & & & & & & & & \\
\hline & & & & & & & & & \\
\hline & & & & & & & & & \\
\hline & & & & & & & & & \\
\hline & & & & & & & & & \\
\hline & & & & & & & & & \\
\hline & & & & & & & & & \\
\hline & & & & & & & & & \\
\hline & & & & & & & & & \\
\hline & & & & & & & & & \\
\hline & & & & & & & & & \\
\hline & & & & & & & & & \\
\hline & & & & & & & & & \\
\hline $\begin{array}{l}\text { RESULTS } \\
\text { OF DEVE }\end{array}$ & $\begin{array}{l}\text { TEND } \\
\text { PMENT }\end{array}$ & & Clear & 3.0 & 7.3 & 734 & 147 & 4.2 & \\
\hline
\end{tabular}

COMMENTS Pretty good recharger and producer. Water cleared, passed and moved to another hole. 


\section{HYORAULIC CONDUCTIVTY CALCULATIONS}

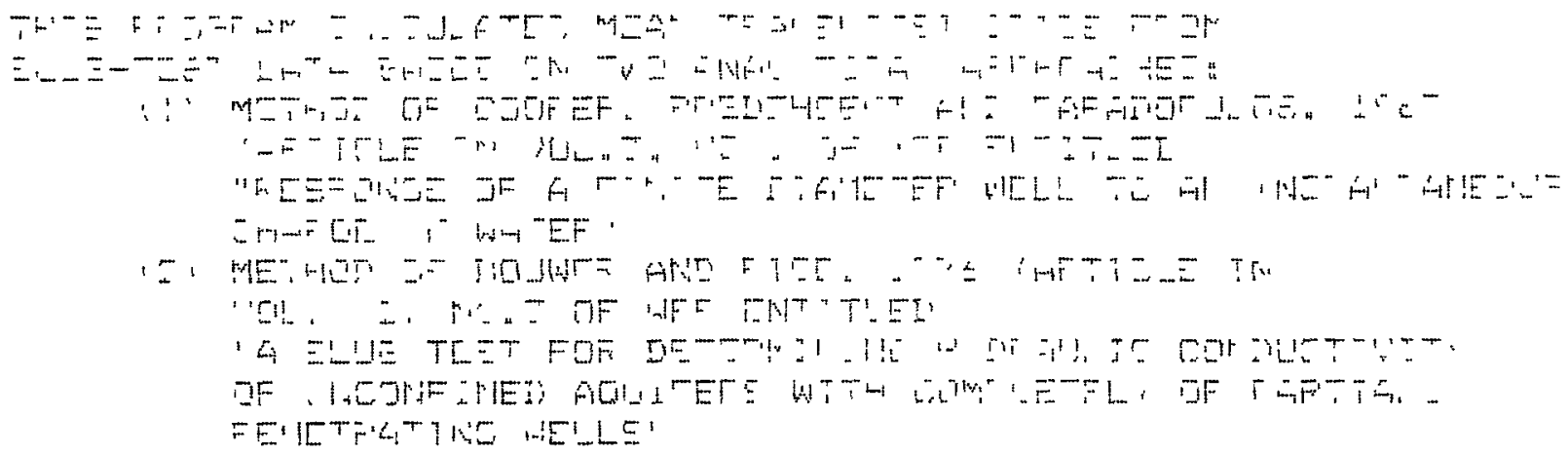

WELL MIL.: : $10^{-}$

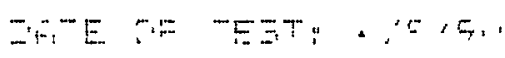

FFOEECT NO.: EE:1-0:

ZLIENT: MAE

SITE LESATEON: WHE 17

EDEE. INE, FIELL INUESTIGATOF: FFULE MCMASTEF

INFUT DATA AFE:

ININEF EASINE DIAMETEF = 4.0O INCHES

INNEF SCFEEN OF' OFEN-HOLE MIAMETEF $=4$. UN INCHES

DIAMETEF' OF DFILLED HOLE = 8. $6:$ INCHES

LENGTH OF SCFEEN OF: INTAK.E FOF.TION = $15.00 \mathrm{FEET}$

DEFTH FFOM STATIC LEVEL TO EOTTOM OF SCFEEN $=29.0 \%$ FEET

THJCHNES OF SATUFATED AOUIFEF: ZONE $=15.00$ TEET

DEFTH TO STATIC WATEF LEVEL BELOW FEF. FOINT = $1.00 \mathrm{FEET}$

EETIMATED FUFOEITY OF GFAVEL FACH $=.20$

FALLING-HEAD INDEX $=1$ ("1" IF FALLING. "." IF FISJHE)

NUMEEF OF DEFTH-TIME DATA FOINTS = =

HG WAS COMFUTED FFOM INTERCEFT OF FLOT OF LOGTH :S. TIME

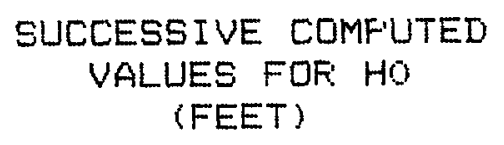




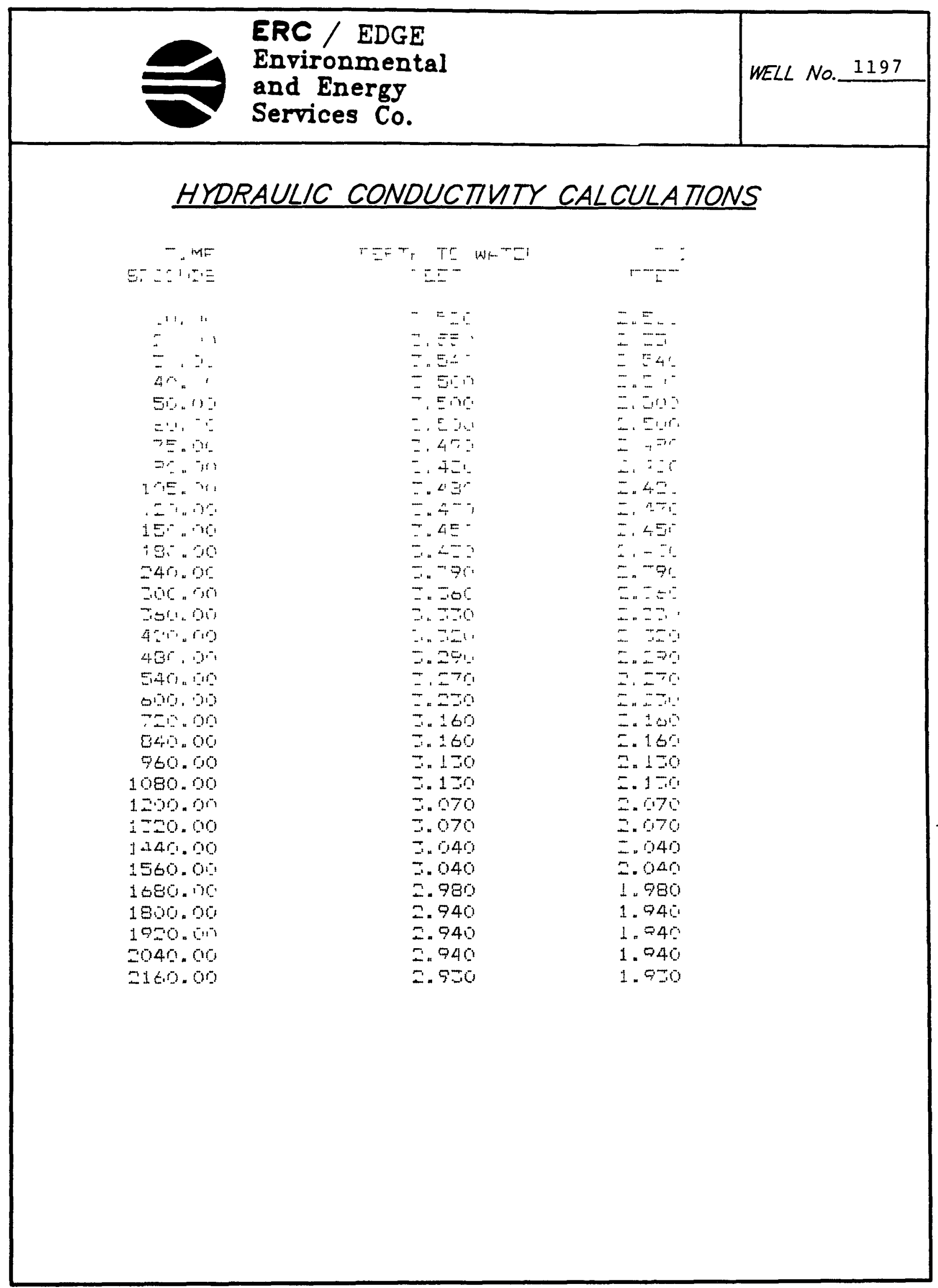




\section{HYORAULIC CONDUCTIVTY CALCULATIONS}

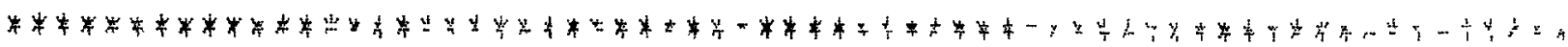

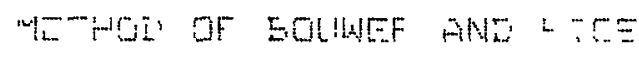

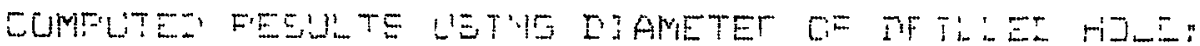

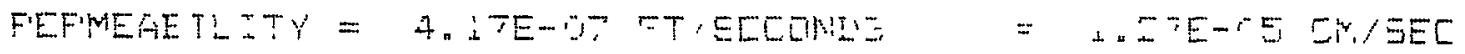

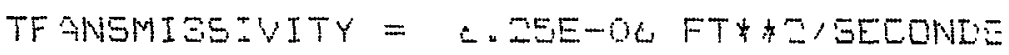

COMFUTEI FESULTS UEING DIAMETEF DF CFSING AND SCFEEM:

PEFMIAEILIT: $:$ D.0E-

TFANSMISEIUITY $=7.55 E-76$ FT*\#2/SECONDS 


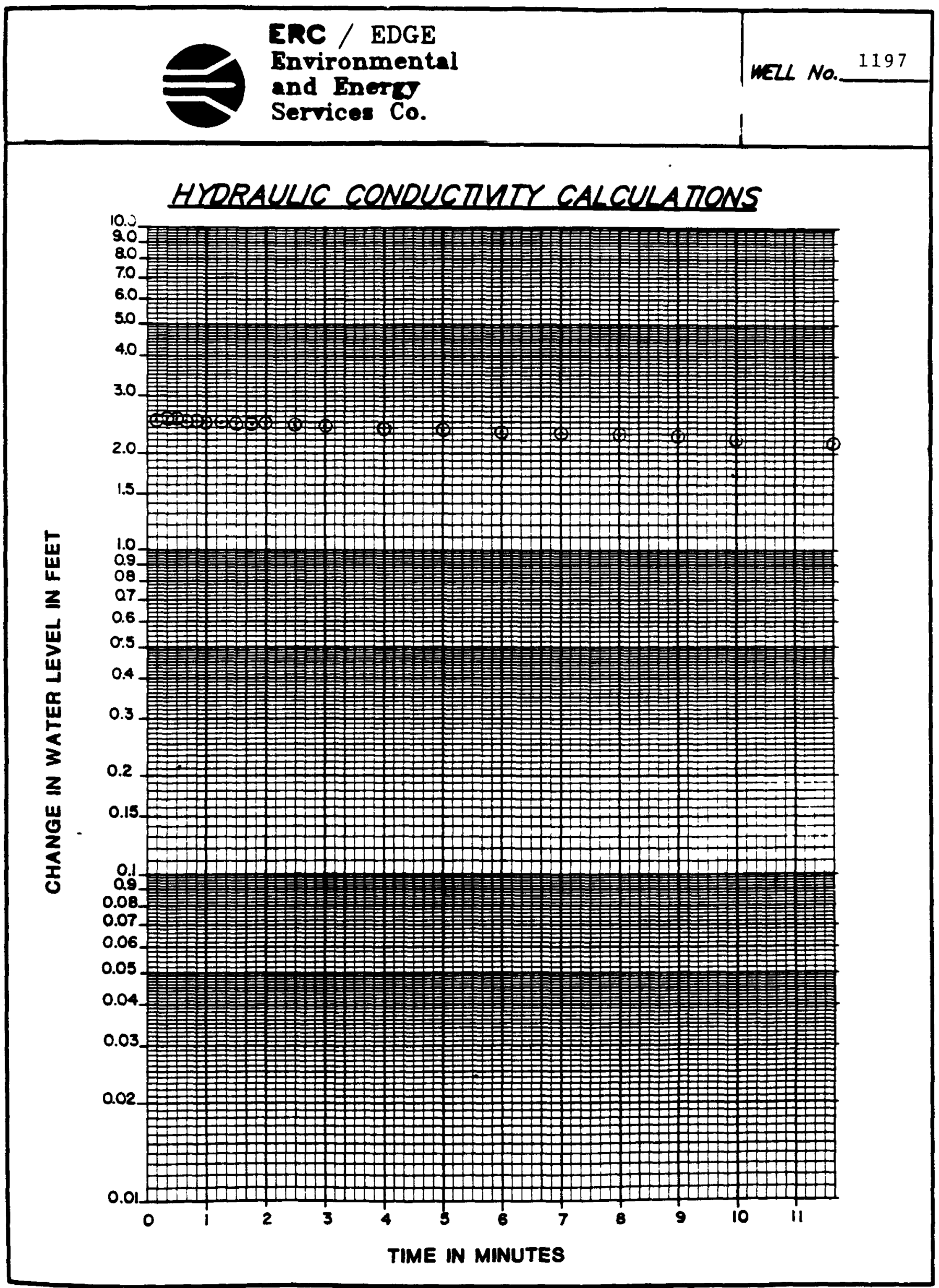

PACE 19 of 20 


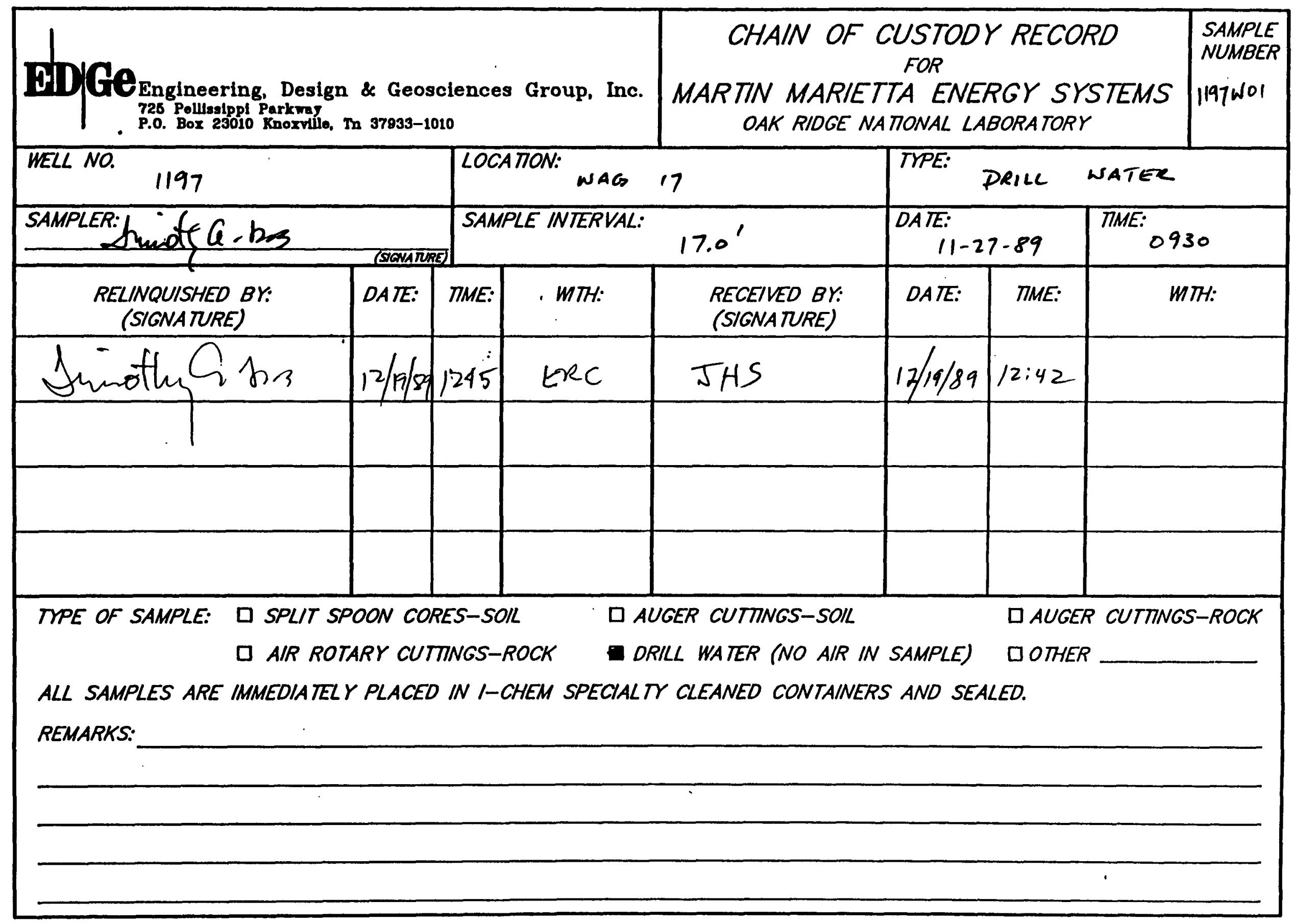


1.0 Goneral Information

1.1 Wo21 Location

Monitoring well number 1198 is located in WAG 17 . It is located in the southeast corner of WAG 17, approximately $250^{\prime}$ southeast of Bldg. 7032. The location is shown on ORNL drawing number C3E20004A075. Survey coordinates for this well are $N 21,214.1516, E 37,984.9834$ (X-10 grid) or latitude $35^{\bullet}-56^{\prime}-07.33^{\prime \prime}$ and longitude $84^{\circ}-17^{\prime}-45.19^{\prime \prime}$. Coordinate data were provided by Martin Marietta Energy systems. The method used for conversion from $x-10$ grid to Tennessee-Lambert state plane coordinates came from the publication wennessee Valley Authority Data Services Branch and Mapping Services Branch, Oak Ridge, Tennessee, DOE Plant Control, November 6, 1985, Field Book: Ess-3115, pp. 1-20." The latitude and longitude were calculated by Adams Craft Herz Walker Engineering, Inc., using methods from the U.S. Coast and Geodetic Survey Publication 62-4, "State Plane Coordinates by Automatic Data Processing."

\subsection{Drilling Information}

Well number 1198 was drilled by Geotek Engineering Company. A Schramm Rotadrill rig was used to drill this boring for monitor well installation under the operation of George Akins with the assistance of steve Rirk. Drilling commenced on 11-9-89 and was Einished on 11-20-89. Paragraph 2.4.1 includes a detailed discussion of the well installation and a well schematic is included on the well installation/completion form. A synopsis of the drilling activity follows. This Information was typed directly from fleld notes and was edited only when necessary for clarification. 
11-9-89: The Ingersoll Rand drill rig was moved to staked locations and set up on plastic. The boring was augered to $18.0^{\prime}$ without refusal. Filled hole to 14.0 and set $14.0^{\circ}$ of $103 / 4$ inch diverter casing and grouted it into place with 4 sacks cement. The rig moved off hole.

11-17-89: A Schramm rig was moved to location and set up on plastic. The boring was deepened to 43.0 feet with a $77 / 8$ inch air rotary tricone bit.

11-20-89: The boring was cleaned out and 45.2' of 2 inch stainless steel casing was set in place. A sand pack was placed erom $25.5^{\prime}$ to $43.3^{\prime}$ and a 2.1 foot bentonite seal was placed above the sand pack.

This well was logged by the EDGe Group of ERC Environmental and Energy Services Co., Inc., hydrogeologist Timothy $A$. Lee. All well construction materials and supplies were from Martin Marietta Energy Syetems approved batches. The batch origin of individual items is shown on the included Monitoring Well Materials Certification form.

\subsection{Teohnionl Information}

\subsection{Decontanination Procedures}

The drilling rig, down hole tools, surface casing, stainless steel screen, stainless steel casing, centralizers, and stainless steel silt trap underwent the cleaning decontamination procedures outlined in the drilling specifications (Release specific Technical Directions for Regulatory Compliance Monitoring Wells Phase 
1. Oak Ridge National Laboratory, Oak Ridge, w.0. K-4147, April 1987, pgs. 2-4). A checklist of the cleaned materials is included with this data package.

\subsection{9}

WAG 17 encompasses approximately 23 acres in Bethel Valley, which is in the Valley and Ridge Physiographic Province of East Tennessee. WAG 17 is underlain by the Middle Ordovician Chickamauga Group consisting mainly of limestone and siltstone. The Chickamauga Group consists of eight units, designated by letters A through H (stockdale, 1951). WAG 17 is underlain by units $E, F, G$ and a portion of $H$. These units consist of thin bedded nodular limestone with clay and shale partings. Portions of units $H$ and $F$ consist of calcareous siltstone alternating with beds of olive gray to maroon shale. The regional strike is $56^{\circ}$ northeast and has a moderate dip of $30^{\circ}$ to $40^{\circ}$ southeast.

\subsection{Baple collootion}

No soil samples were collected during drilling. A drill water sample was collected from the water pump on the drill rig on 11-17-89. Analytical results for the water sample described above can be obtained from the Remedial Action Program data base at ORNL.

The Schram Rig compressed air was sampled with a cloth eilter inserted between dri11 rods on 11-17-89. The sample was examined with an ultraviolet light for the presence of hydrocarbons. The filter showed no evidence of hydrocarbons. 


\subsection{Installetion and Development}

\subsubsection{Inotaliation}

This was a type D well. A 6-inch diameter boring was augered from ground surface to (18.0 feet). The air rotary method was required to complete the boring to the specified total well depth. Therefore, a 22.0-inch diameter boring was augered from ground surface to 14.0 feet and a 10 3/4inch diverter casing was installed and grouted. A 7 7/8inch diameter boring was then drilled with an air rotary tricone roller bit from 14.0 to 43.3 feet. A 2 -inch diameter stainless steel screen with bottom cap was installed from 27.8 to 43.0 feet. A 2-inch diameter stainless steel casing was installed above the screen at 27.8 feet and extended 43.0 feet above ground surface. A sandpack was then tremied into the annular space from 25.5 to 43.0 feet, with a 2.1-foot bentonite pellet seal poured into the annular space above the sandpack from 23.4 to 25.5 feet. The annular space from the top of the bentonite seal to the surface was tremie-grouted with a cement/bentonite slurry. A detail of the well is included on the well installation/completion form.

\subsubsection{We11 Development}

Well number 1198 was developed to remove drill cuttings, silt, and other fines. The monitoring well was developed using a Geoguard pump with an air compressor. All pumps were cleaned prior to use according to specified cleaning procedures (see Paragraph 2.1) . The well was developed unt1l a measured total of 36.8 gallons of water had been evacuated and the clarity of the discharge water was 
approved by the company representative. The final turbidity value measured at completion was $>100$ NTU's. A development form showing the exact method of development and other pertinent data is appended.

\subsubsection{Installation of Dedicated Monitoring Nell Pump}

After the well was developed, a Geoguard Model No. 5614 dedicated monitoring well pump was installed on 4-19-90 at a depth of 40.3 feet below ground surface. These pumps are decontaminated at American sigma and are sent prepackaged. A copy of the pump certification is kept on file at ORNL.

\subsection{Hydraulic Conductivity Testing}

Well number 1198 was tested for the determination of hydraulic conductivity of the aquifer in the vicinity of the well screen. This was accomplished by instantaneously adding a known quantity of water to the monitoring well and measuring the recovery of the water level over time. The changing water levels were measured using a Druck Model DPI-600 pressure transducer. The hydraulic conductivity value of $8.66 \times 10^{-4} \mathrm{~cm} /$ second (shown as permeability on the hydraulic conductivity calculations printout attached) was calculated using the Bouwer and Rice method. A computer printout of the hydraulic conductivity calculations is included in this data package. 


\section{PRE-DRILLING CHECKLIST FOR MONITORING WELLS}

RRE-DRILUNG IASKS

1. EXCAVTION PERMIT OBTAINED

2. ALL EOUIPMENT HAS BEEN CLEANEO BEFORE DRILLING.

30. SCREEN AND CASING HAVE BEEN WASHED, STEAMED, RINSED WTH DE-IONIZED OR DISTILED WATER, RINSED WTH ISOPROPR ALCOHOL, WRAPPED WTH PROTECTVE COVERING AND STORED OFF THE GROUND.

36. PRE-PACKAGED SCREENS, CASING AND CENTRALIZERS WERE USED.

4. WORK AREA FOR SAMPLE EXAMINATION COVERED WIH CLEAN POL YETHRENE.

5. CLEAN KNIVES, QLOVES, SAMPLE JARS AND LABEZS ON HAND.

6. POLYETHENE COVER IN PLACE OVER HOLE.

7. ARR ROTARY COMPRESSED AIR SAMPLED.
COMPLIANCE

\begin{tabular}{|c|c|}
\hline $\begin{array}{c}\text { DAIE } \\
11-09-89 \\
\end{array}$ & $\begin{array}{l}\text { INITALS } \\
\angle A B\end{array}$ \\
\hline $11-09-89$ & $C A B$ \\
\hline $\mathrm{N} / \mathrm{A}$ & \\
\hline $11-20-89$ & \\
\hline $11-09-89$ & $C A B$ \\
\hline $11-09-89$ & $C A B$ \\
\hline $11-17-89$ & \\
\hline $11-17-89$ & \\
\hline
\end{tabular}

RESUL TS:

ADDITONAL NOTES/OBSERVATONS.

Q. delad Bále 11-09-89

G. AlIigon Bailey

OESERVER SINATUREPATE Sun thath 11-20-89

Timothy A. Lee

PACE 6 of 17 


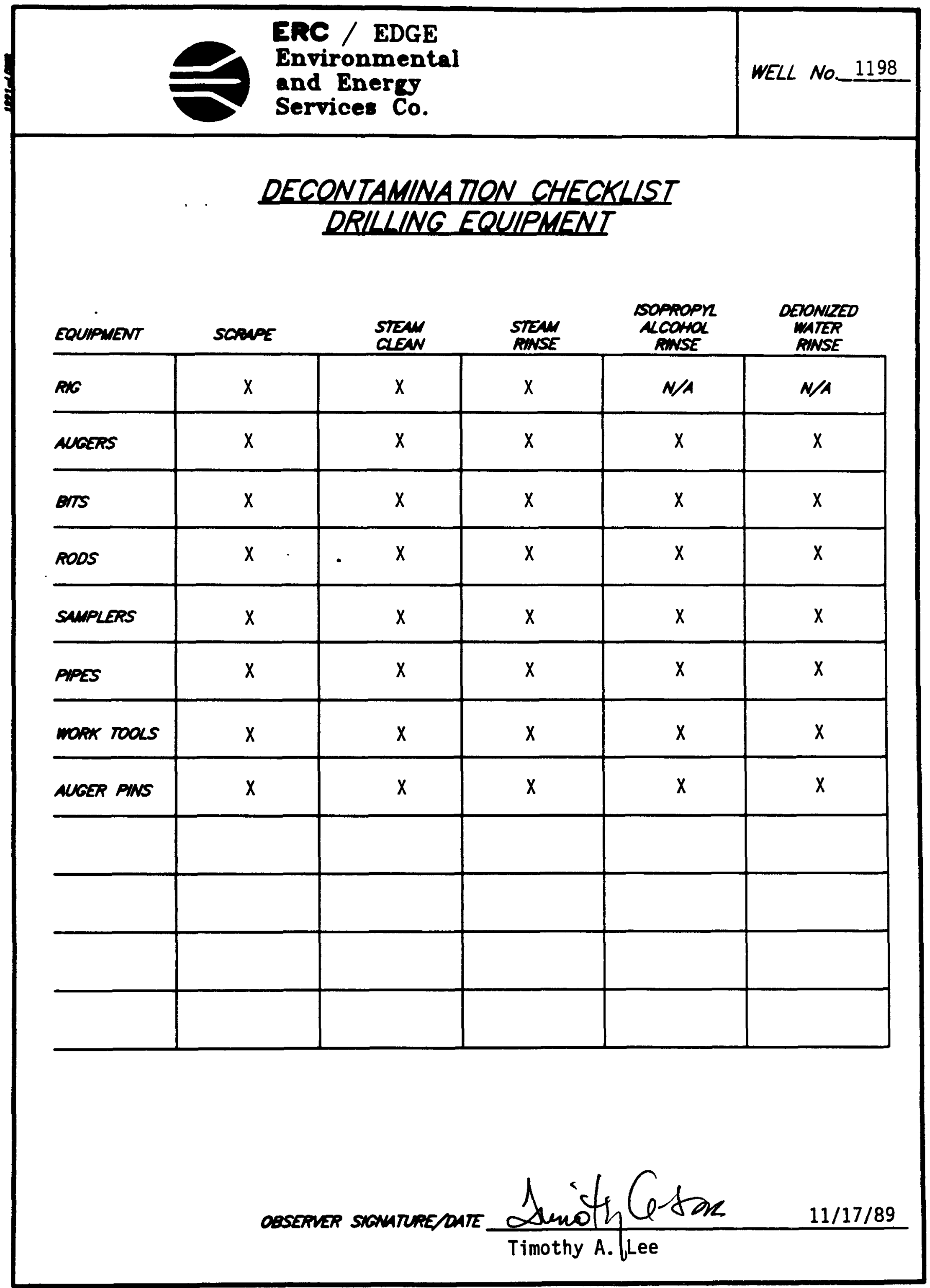

PACE 1 or 17. 


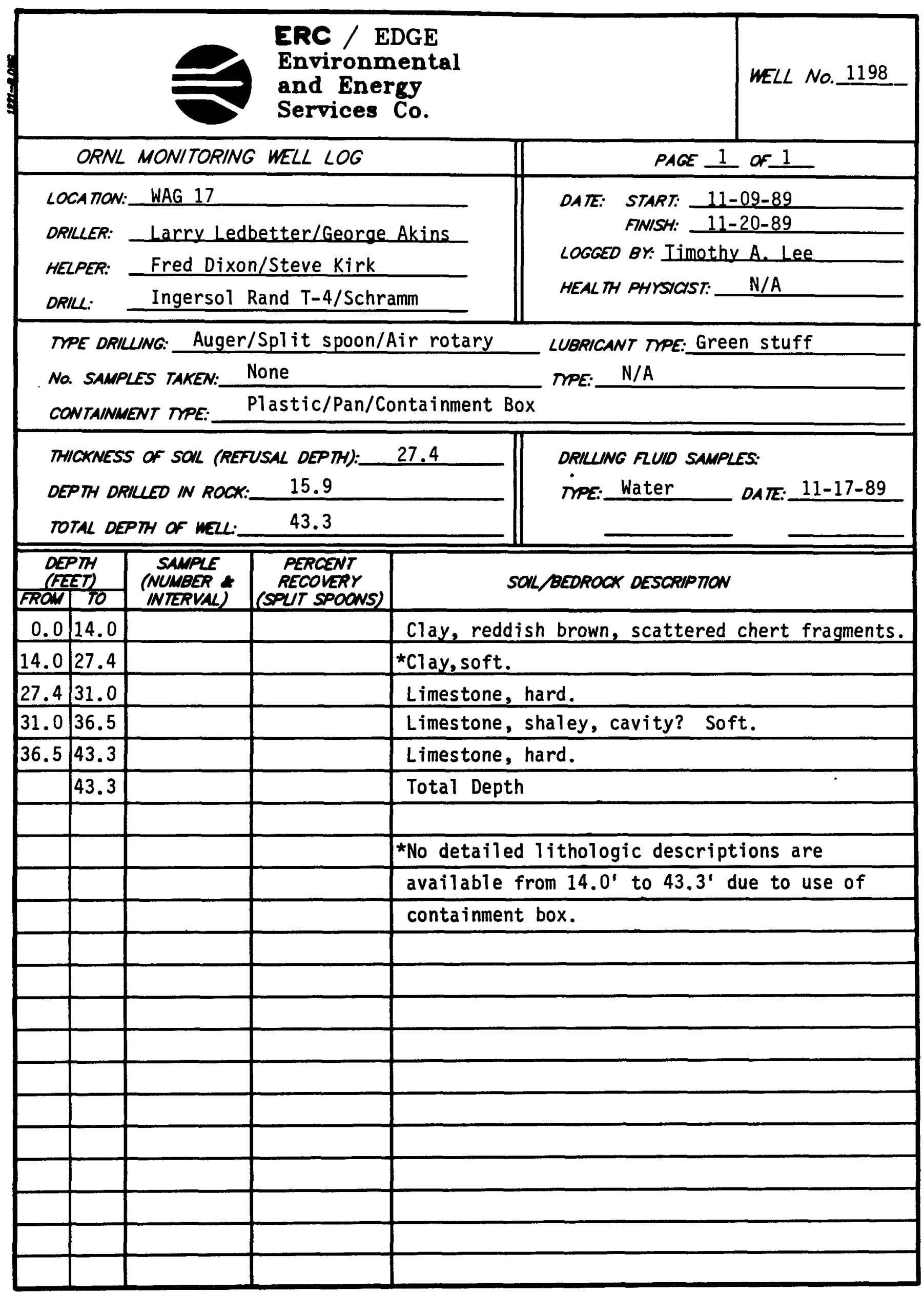

PAGE 8 or 17. 


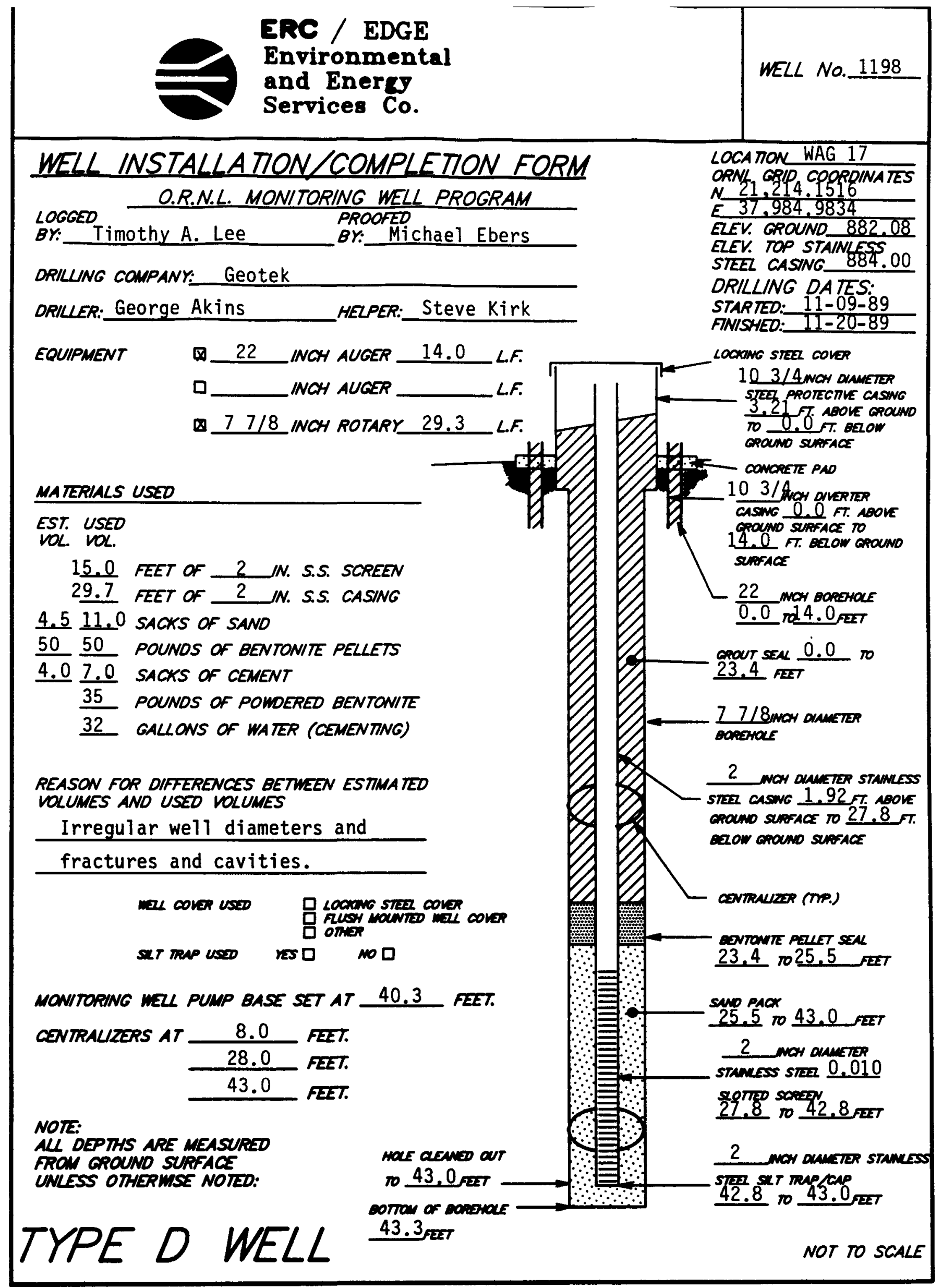

PACE 9 of 17. 


\section{MONITORING MELL MATERIALS CERTIFICA TON}

ITEM/MA TERIAL DATE USED BATCH NUMBER

SAND

BENTONITE

Pellets

STAMLESS STEER SCREEN

Powder

STAINLESS STEEL CASWNG

STAMLESS STER CENTRALIZERS

STAMKESS STEER CAPS

MONTORNG MELL PUMP

(PREPACKACED

Grour

(PREPACKAGED

(PREPACKACDD

(PREPACKACED

Yes
no
Mes)

$11-20-89$

a $\begin{gathered}\text { nes } \\ \text { no }\end{gathered}$

\begin{tabular}{l|l}
$11-20-89$ & 1 \\
\hline
\end{tabular}

MELl COVERS

SLAFACE CASNG

COMMENTS:

\section{Sunotlecesps}

OSEERER SGNATnESOAT Timothy A. Lee

11-20-89

D.Chankoojgte

D. Charles Lytle

4-19-90

PACE 10 or 17 


\section{POST-WELL COMPLETION CHECKLIST}

\section{POST-WELL COMPLETON TASKS}

1. WUO SCRAPED FROM ALGERS SAMPLERS, ANO ALL OTHER EOUPMENT.

2. NL WUO FRON RNG ANO EQUMANENT SCRAPINCS ANO CUTTINOS DSPOOSED OF WN ACCORDANCE WTH THE SeECrica now Prowoed.

3. WEL DEVZLOED IN ACCORDANCE MTH THE SPECATCA IION* PROMOED AND OETAKS OF THE DEVELOPUENT ACTUT RECOROED.

1. DRKLWG STE PAOPER Y CLEANED UP AFTER complemon of MZL NSTALA DON.

COMPLIANCE

DA.E INITALS

$11 / 20 / 89$

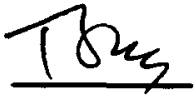

$11 / 20 / 89$

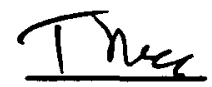

$4 / 19 / 90$

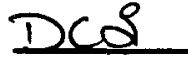

$11 / 20 / 89$

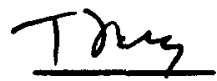

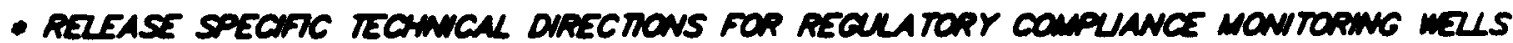

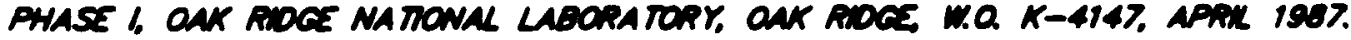

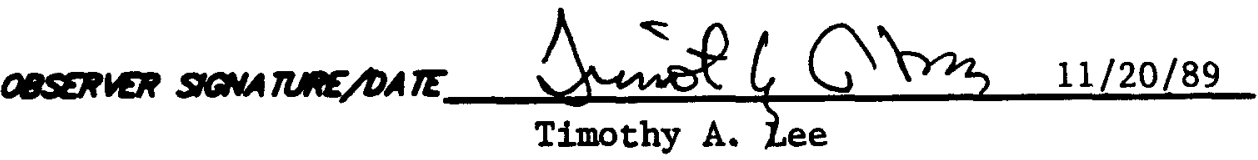

D. Chanlesolute 4/19/90

D. Charles Lytled 
ERC / EDGE

Environmental

and Energy

WELL NO. 1198

Services Co.

DEVELOPMENT DETAILS

METHOD OF SEYELEMENT Surging and Pumping

DEVEZOPMENT

BESAN DATE:

$3 / 28 / 90$

TME:

DEVELOPNENT

ENDWG DATE:

$4 / 19 / 90$

DEVZCOPWENT

QBSTRVD BY.

D. Charles Lytle

one weze vacume: 9.8 aneovs

TOTN GNLONS PUMPED: 368 TOTN MTL VOCUMES PCMPED: 37.5

INTML PH: 7.7 GNAL PH: 7.8

MUTAL covouctinTr (us): 786 FNA covoucthr (us): 720

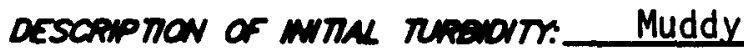

Descaption or FWA Rnewory. Muddy

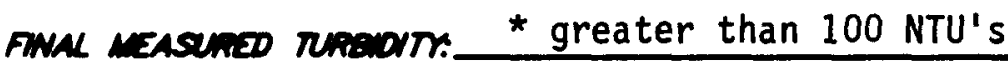

mel APrnove er. R. C. Williams MMES

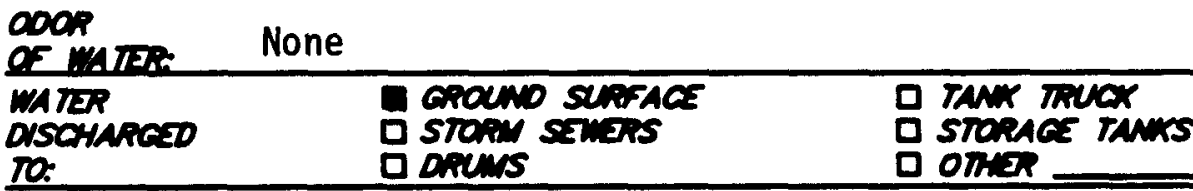

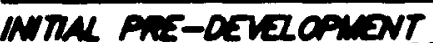

mATS OJPT: 25.4 feet from ground surface.

\section{DEVELOPMENT OBSERVATIONS}

coserver sovatuespare D. Chrabosute 4/19/90

D. Charles Lytie 
ERC / EDGE

Environmental

and Energy

Services Co.

WEL NO. 1198

LOCA TION: WAG 17

OATE: $3 / 28 / 90$

\section{MONITORING WELL DEVELOPMENT PROGRESS}

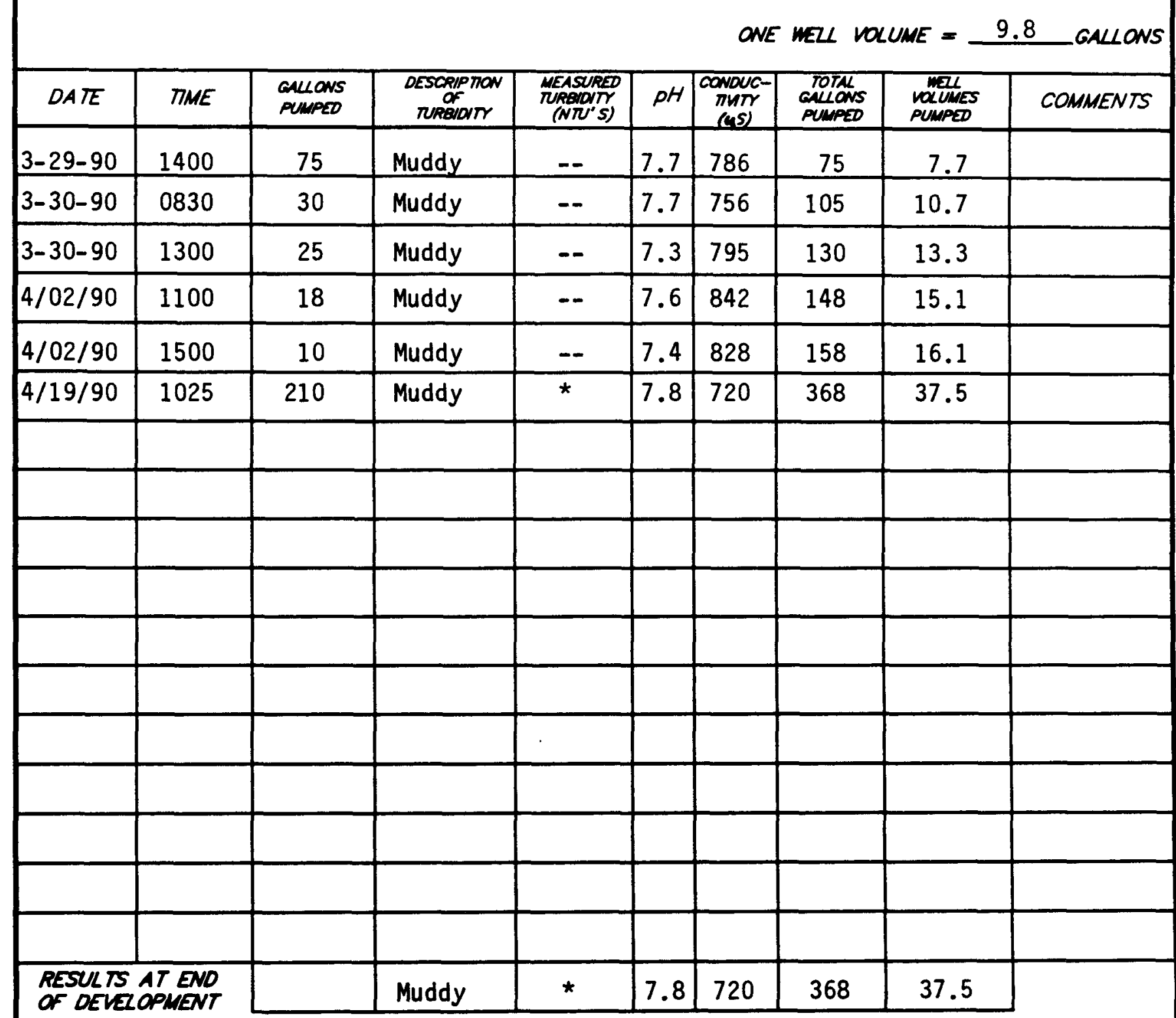

COMWENTS Poor recharger and producer. Pumped dry, remained muddy the entire time, would not clean up. Used work over rig four different times and still would not come clean. Had to pass with 37.5 well volumes. * greater than 100 NTU's. 


\section{HYDRAULIC CONDUCTIVTY CALCULATIONS}

PFUEFPH, EUE?,

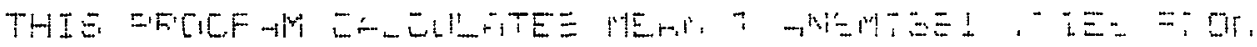

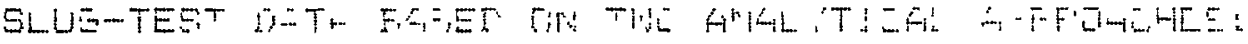

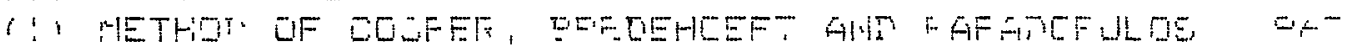

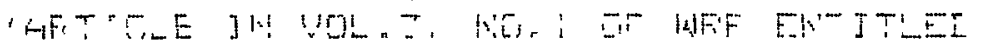

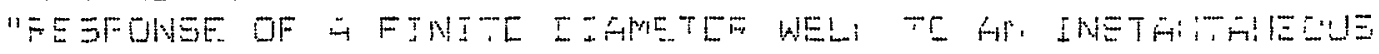

CHAFEE OT WHED'"

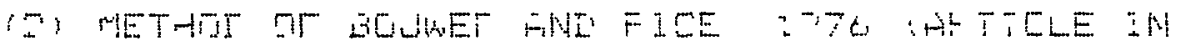

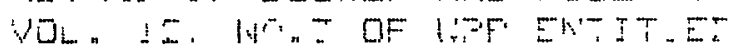

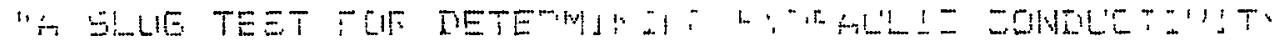

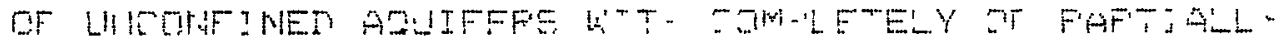

FENETFATINE WFLL $\because "$ "

WELI. $10 .: 119 E$

DF. TE OF TEET: $5: 1,4 \%$

FFOJECT NO.: EEII-1OO

C:IEIAT: MWES

STTE LOCATION: WAE 17

ERGE "INC, FIELD INVESTIEATOF" IFFUCE MEMAETEF"

INFUT DATA AFE:

INNEF CASING DIAMETEF $=2.00$ INCHES

INNEF: SCFEEN OF: OFEN-HOLE DIAMETEF $=2.00$ INCHES

DIAMETEF OF DFILLED HOLE $=8.00$ INCHES

LENGTH OF SCFEEN DF INTAYE FOFTION = 15.00 FEET

DEFTH FFOM STATIC LEVEL TO BOTTOM OF SCFEEN $=19.10$ FEET

THICINESS OF SATUFATED AQUIFEF ZONE $=15.00$ FEET

DEFTH TO STATIC WATEF: LEVEL BELOW FEF. FOINT = . . FEET

ESTIMATED FOFOSITY OF GFAVEL FGCH $=.20$

FALLING-HEAD INDEX $=1$ ("1" IF FALLINE. "O" IF FISING.

NUMEEF OF DEFTH-TIME DATA FOINTS = 11

HO WAS COMFUTED FF:OM INTEF:CEFT OF PLOT OF LOG(H) VS. TIME

SUCCESSIVE COMFUTED

VALUES FOF: HO

(FEET)

$\pm .1402$

$=.2931$ 


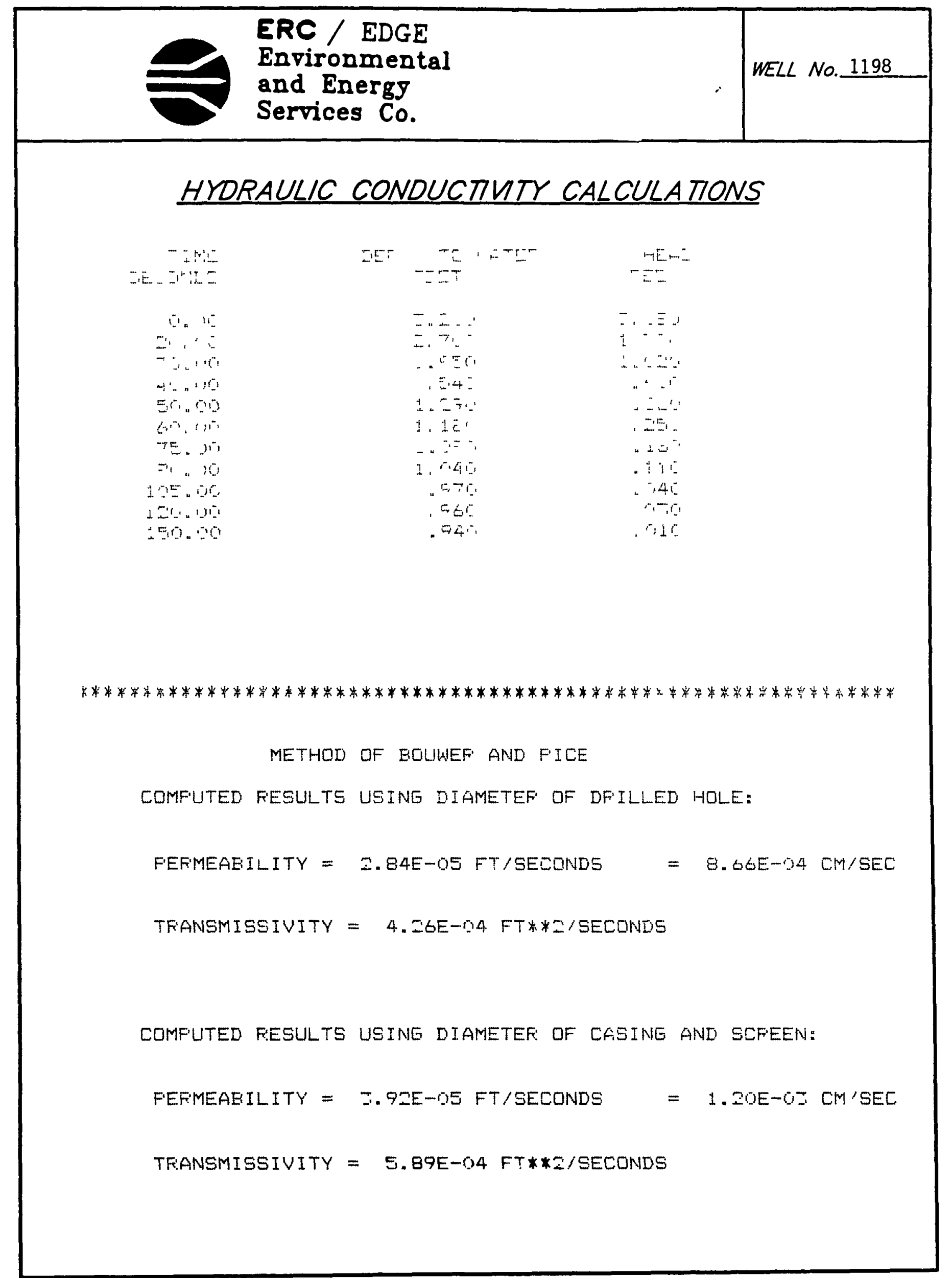


ERC / EDGE

Environmental

and Bnergy

MEUL No.

1198

Services Co.

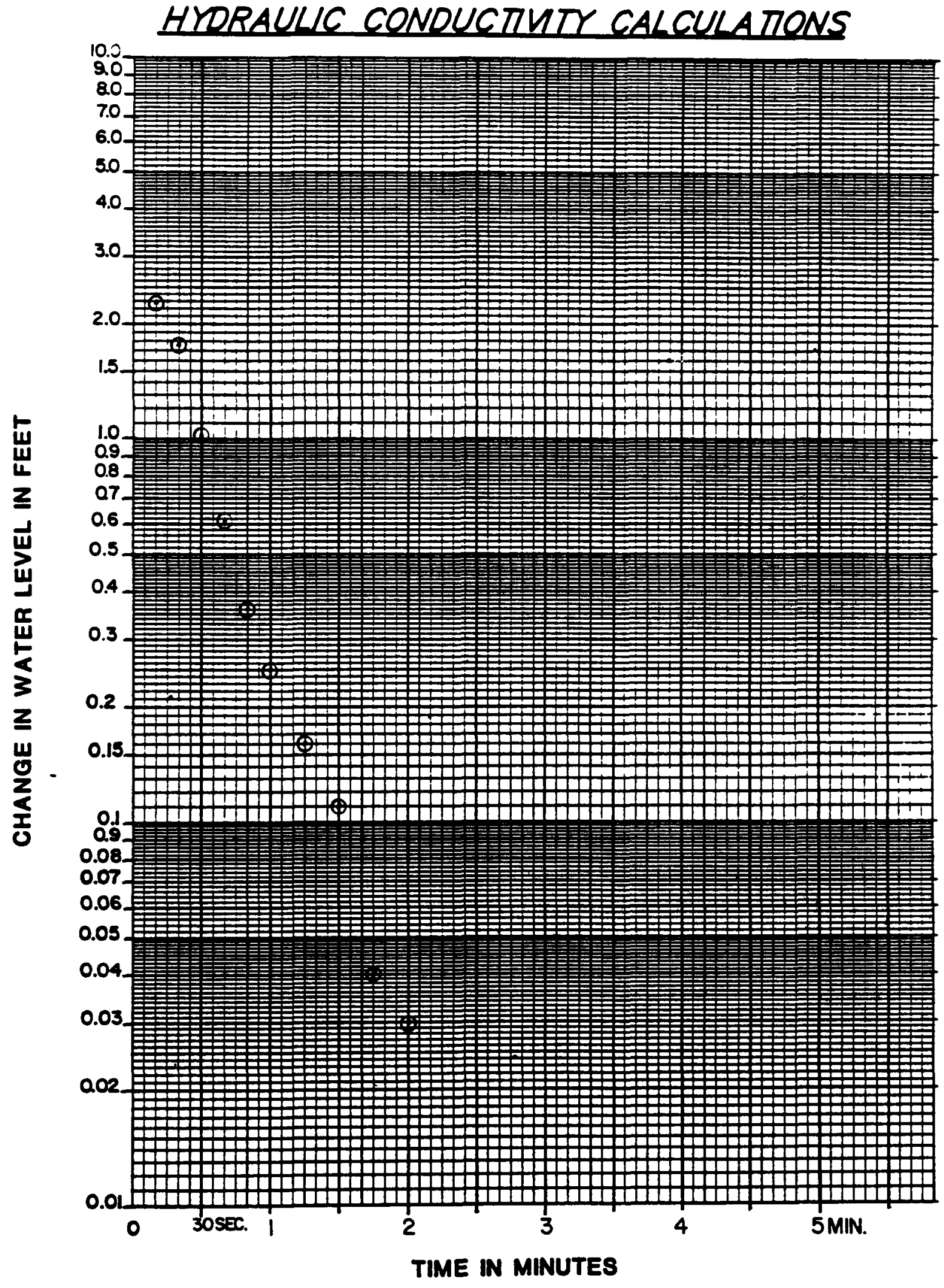

PACE 16 of 17 


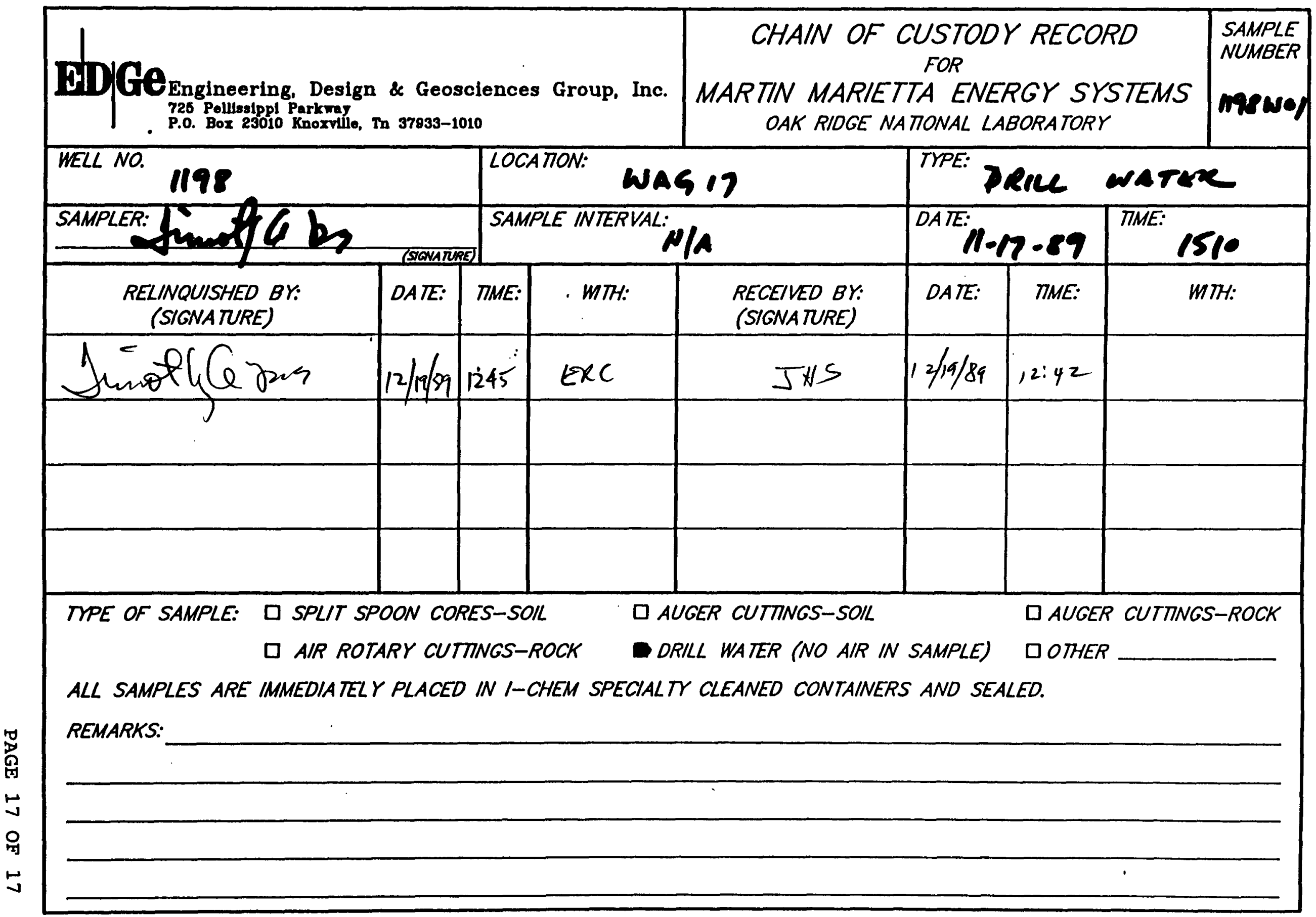




\subsection{General Information}

\subsection{We1l Location}

Monitoring well number 1199 is located in WAG 17. It is in the southeast corner of WAG 17 approximately $300^{\prime}$ southeast of Bldg. 7032. The location is shown on ORNL drawing number C3E20004 A075. Survey coordinates for this well are N 21,206.5665, E 37,967.5922 (X-10 grid) or latitude $35^{\circ}$ $56^{\prime}-07.17^{\prime \prime}$ and longitude $84^{\circ}-17^{\prime}-45.31^{\prime \prime}$. Coordinate data were provided by Martin Marietta Energy systems. The method used for conversion from $x-10$ grid to TennesseeIambert state Plane Coordinates came from the publication "Tennessee Valley Authority Data Services Branch and Mapping Services Branch, Oak Ridge, Tennessee, DOE Plant Control, November 6, 1985, Field Book: Ess-3115, pp. 120." The latitude and longitude were calculated by Adams Craft Herz Walker Engineering, Inc., using methods from the U.S. Coast and Geodetic Survey Publication 62-4, "State Plane Coordinates by Automatic Data Processing."

\subsection{Drilling Information}

Well number 1199 was drilled by Geotek Engineering Company. An Ingersoll Rand and a Schramm air rotary rig were used to dr111 this boring for monitor well installation under the operation of Iarry Ledbetter and George Akins with the assistance of Fred Dixon and steve Kirk. Drilling commenced on 11-7-89 and was Iinished on 11-15-89. Paragraph 2.4.1 Includes a detalled discussion of the well Installation and well schematic is included on the well installation/completion form. A synopsis of the arilling activity follows. This information was typed directly from field notes and was edited anly when necessary for clarification. 
11-7-89: The $T-4$ and equipment were decontaminated and mobilized to the site. Plastic was layed down and a six-inch boring was split spooned and augered to a refusal depth of $13.0^{\prime}$. Soil samples were taken by Bechtel. A bulk density sample was taken from 10.30 to 10.64 feet. A $22.0^{\prime \prime}$ boring was then augered to $7.0^{\prime}$ and a 15 $1 / 4^{\mathrm{W}}$ diverter casing set.

11-9-89: The $T-4$ and equipment were decontaminated, mobilized to the site and rigged up. A 14.0 inch boring was drilled to a depth of $18.0^{\prime}$ with a tricone bit. A 10 inch surface casing was installed to $18.0^{\circ}$, a bentonite seal poured and the annulus partially grouted.

11-10-89: The grouting was completed.

11-13-89: The schramm and equipment were decontaminated, mobilized to the location and rigged up. An eight-inch boring was advanced to 23.9 ' with a tricone bit.

11-14-89: After reaching a depth of 55.0' the borehole was cleaned and after 1 hour $2.6^{\circ}$ of water had accumulated in the borehole. Water and air samples were taken at $23.9^{\circ}$. The boring was advanced to $65.0^{\prime}$ and after 1 hour of recharge, $7.2^{\circ}$ of water was present. The decision was made by R. C. Nilliams to drill the well to $73.0^{\prime}$ and set $20.0^{\prime}$ of screen. The boring was advanced to $73.0^{\circ}$ and after 1 hour of recharge $9.2^{\prime}$ of water had accumulated. 
11-15-89: The water level was checked in the morning and there was $41.2^{\prime}$ of water in the borehole. The 4 inch stainless steel screen and casing were installed, sand was tremied and bentonited poured. The remaining annulus was grouted.

This well was logged by the EDGe Group of ERC Environmental and Energy Services Co., Inc., hydrogeologist c. Allison Bailey and Timothy A. Lee. All well construction materials and supplies were from Martin Marietta Energy Systems approved batches. The batch origin of individual items is shown on the included Monitoring Well Materials Certification form.

\subsection{Technical Information}

\subsection{Decontamination Procedures}

The drilling rig, down hole tools, surface casing, stainless steel screen, stainless steel casing, centralizers, and stainless steel silt trap underwent the cleaning decontamina-tion procedures outlined in the drilling specifications (Release specific Technical Directions for Regulatory Compll-ance Monitoring Wells Phase 1, Oak Ridge National Laboratory, Oak Ridge, w.O. K4147, April 1987, pgs. 2-4). A checklist of the cleaned materials is included with this data package.

\section{$2.2600109 y$}

WAG 17 encompasses approximately 23 acres in Bethel valley, which is in the Valley and Ridge Physiographic Province of East Tennessee. WAG 17 is underlain by the Middle 
Ordovician Chickamauga Group consisting mainly of limestone and siltstone. The Chickamauga Group consists of eight units, designated by letters A through H (Stockdale, 1951). WAG 17 is underlain by units E, F, G and a portion of $H$. These units consist of thin bedded nodular limestone with clay and shale partings. Portions of units $H$ and $F$ consist of calcareous siltstone alternating with beds of olive gray to maroon shale. The regional strike is $56^{\circ}$ northeast and has a moderate dip of $30^{\circ}$ to $40^{\circ}$ southeast.

\subsection{Bample Collection}

Soll samples were collected during drilling by Bechtel National, Inc., the Remedial Investigation/Feasibility study constractor. A drill water sample was collected from the water pump on the drill rig on 11-14-89. Analytical results for the water sample can be obtained from the Remedial Action Program data base at ORNL. The analytical results for the soil samples can be obtained from Bechtel.

A bulk density soil sample was collected from the split spoon sample interval from 10.30 to 10.64 feet. The sample was measured and weighed, and a bulk density of 1.94 grams/ $\mathrm{cm}^{3}$ was calculated.

The Schramm Air Rotary Rig's compressed air was sampled with a cloth filter inserted between drill rods on 11-1489. The sample was examined with an ultraviolet light for the presence of hydrocarbons. The filter showed no evidence of hydrocarbons. 


\subsection{Installation and Development}

\subsubsection{Installation}

This was a type B well. A 6-inch diameter boring was split spooned and augered from ground surface to a total depth of 13.0 feet. A 22.0 -inch diameter boring was augered from ground surface to 7.0 feet. A 15 1/4-inch diverter casing was installed from surface to 7.0 feet below ground surface and grouted in place. The boring was then extended past the refusal depth with a 14.0-inch air rotary tricone roller bit from 7.0 feet to 18.0 feet. A 10 3/4-inch diameter string of decontaminated steel surface casing was installed from 0.0 feet to 18.0 feet, sealed with a 2.0foot bentonite pellet layer from 16.0 feet to 18.0 feet, and tremie-grouted in place. The surface casing minimizes potential cross contamination between the regolith and bedrock water bearing zones. After the surface casing was installed, the air rotary method was used to drill an 8inch diameter boring to a total depth of 73.0 feet. A 4inch diameter stainless steel cap was installed from 72.8 feet to 72.6 eeet. A 4-inch diameter stainless steel screen was installed from the top of the cap at 72.6 feet to 52.6 feet. A 4-inch diameter stainless steel casing was installed from the top of the screen at 52.6 feet and extended 1.58 feet above ground surface. A sandpack was then tremied into the annular space from 72.8 to 47.8 feet, with a 3.1-foot bentonite pellet seal poured into the annular space above the sandpack from 47.8 to 44.7 feet. The annular space from the top of the bentonite seal to the surface was tremie grouted with a cement/bentonite slurry. A detalled schematic of the well is included on the well installation/completion form. 
Well number 1199 was developed to remove drill cuttings, silt, and other fines. The monitoring well was developed using a Geoguard pump with an air compressor. All pumps were cleaned prior to use according to specified cleaning procedures (see Paragraph 2.1). The well was developed until a measured total of 146 gallons of water had been evacuated and the clarity of the discharge water was approved by the company representative. The final turbidity value measured at completion was $4.0 \mathrm{NTU}$ 's. A development form showing the exact method of development and other pertinent data is appended.

2.4.3 Installation of Dadicated Monitoring Nell Pump

After the well was developed, a Geoguard Model No. 5614 dedicated monitoring well pump was installed on 3-30-90 at a depth of 70.0 feet below ground surface. These pumps are decontaminated at American sigma and are sent prepackaged. A copy of the pump certification is kept on file at ORNL.

\subsection{Hydraulia conductivity Teating}

Well number 1199 was tested for the determination of hydraulic conductivity of the aquifer in the vicinity of the well screen. This was accomplished by instantaneously adding a known quentity of water to the monitoring well and measuring the recovery of the water level over time. The changing water levels were measured using a Druck Model DPI-600 pressure transducer. The hydraulic conductivity 
value of $2.70 \times 10^{-5} \mathrm{~cm} /$ second (shown as permeability on the hydraulic conductivity calculations printout attached) was calculated using the Bouwer and Rice method. A computer printout of the hydraulic conductivity calculations is included in this data package. 


\section{PRE-DRILLING CHECKLIST FOR MONITORING WELLS}

RRE-DRILUNG TASKS

1. EXCAVTION PERMIT OBTAINED

2. ALL EQUIPMENT HAS BEEN CLEANED BEFORE DRILING.

30. SCREEN AND CASING HAVE BEEN WASHED, STEAMED. RINSED WIH DE-IONIZED OR DISTILED WATER, RINSED WTH ISOPROPV ALCOHOL, WRAPPED WTH PROTECTVE COVERING AND STORED OFF THE GROUND.

36. PRE-PACKAGED SCREENS, CASING AND CENTRALIZERS WERE USED.

4. WORK AREA FOR SAMPLE EXAMINATION COVERED WTH CLEAN POL YETHIRENE.

5. CLEAN KNIVES, GLOVES, SAMPLE JARS AND LABEZS ON HAND.

6. POL YETHYENE COVER IN PLACE OVER HOLE.

7. ANR ROTARY COMPRESSED AIR SAMPLED.
COMPLIANCE

$\frac{\frac{1 N A T E}{11-07-89}}{\frac{11-07-89}{N / A}} \underset{\text { NARALS }}{C A B}$

$11-14-89$

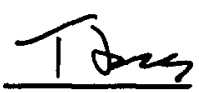

$11-07-89$

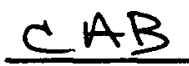

11-07-89 CAB

$11-07-89 \quad C A B$

11-14-89 Then

RESULTS: No detectable hydrocarbons observed under ultra violet light.

ADDITONAL NOTES/OBSERVATIONS.

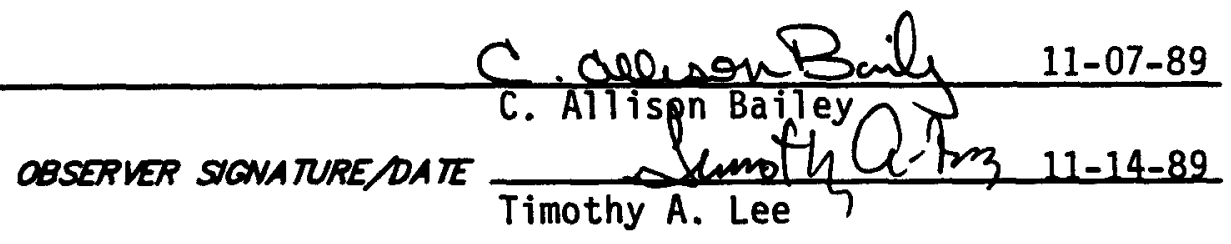

PACE 8 of 20. 


\section{DECONTAMINATION CHECKLIST DRILLING EQUIPMENT}

\begin{tabular}{|c|c|c|c|c|c|}
\hline EQUIPMENT & SCRAPE & $\begin{array}{l}\text { STEAN } \\
\text { CLEAN }\end{array}$ & $\begin{array}{l}\text { STEAM } \\
\text { RINSE }\end{array}$ & $\begin{array}{c}\text { ISOPROPL } \\
\text { NLCOHOL } \\
\text { RINSE }\end{array}$ & $\begin{array}{c}\text { DEIONIZED } \\
\text { WATER } \\
\text { RINSE }\end{array}$ \\
\hline$R / G$ & $x$ & $x$ & $x$ & $N / A$ & $N / A$ \\
\hline AUGERS & $x$ & $x$ & $x$ & $x$ & $x$ \\
\hline BITS & $x$ & $x$ & $x$ & $x$ & $x$ \\
\hline ROOS & $x$ & $x$ & $x$ & $x$ & $x$ \\
\hline SAMPLERS & $x$ & $x$ & $x$ & $x$ & $x$ \\
\hline PIPES & $x$ & $x$ & $x$ & $x$ & $x$ \\
\hline WORK TOOLS & $x$ & $x$ & $x$ & $x$ & $x$ \\
\hline AUGER PINS & $x$ & $x$ & $x$ & $x$ & $x$ \\
\hline & & & & & \\
\hline & & & & & \\
\hline & & & & & \\
\hline & & & & & \\
\hline
\end{tabular}

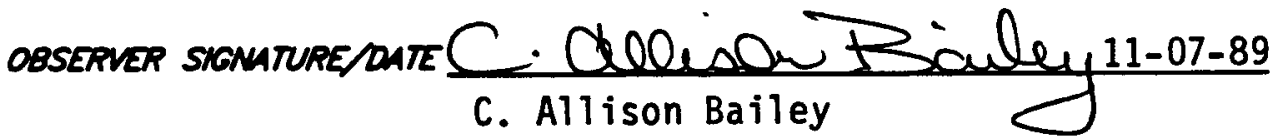




\begin{tabular}{|c|c|c|c|c|}
\hline & & & $\begin{array}{l}\text { ERC / E] } \\
\text { Environm } \\
\text { and Ener } \\
\text { Services }\end{array}$ & $\begin{array}{l}\text { GE } \\
\text { ental } \\
\text { gy } \\
\text { Co. }\end{array}$ \\
\hline & ORNL & MONITORING & G WELL LOG & PAGE 2 of 2 \\
\hline $\begin{array}{l}\text { OEP } \\
\text { IFEE } \\
\text { FROM }\end{array}$ & $\frac{D T H}{E T)}$ & $\begin{array}{l}\text { SAMPLE } \\
\text { (NUMBER } \\
\text { INTERVAL) }\end{array}$ & $\begin{array}{c}\text { PERCENT } \\
\text { RECOVERY } \\
\text { (SPUT SPOONS) }\end{array}$ & SOLLBEDROCK OESCRIPTION \\
\hline 9.0 & 10.5 & & & (continued) light brown. Moist. Plastic. \\
\hline 10.5 & 11.0 & & $100 \%$ & Clay, mottled, light olive gray and light \\
\hline & & & & brown. Dry to damp. Slightly crumbly. The \\
\hline & & & & bottom of the spoon contains calcareous silt- \\
\hline & & & & stone fragments. Bulk density taken from \\
\hline & & & & $10.3^{\prime}$ to $10.64^{\prime}=1.94 \mathrm{grams} / \mathrm{cm}^{3}$. \\
\hline 11.01 & 11.5 & & $100 \%$ & Limestone, crushed fragments, light olive gray, \\
\hline & & & & fine grained, very hard with some calcite \\
\hline & & & & veins. Some edges ironstained. Rock is \\
\hline & & & & float material. \\
\hline 11.51 & 13.0 & & $100 \%$ & Clay, mottled, light brown, dark yellowish \\
\hline & & & & orange and moderate greenish yellow. Firm, \\
\hline & & & & hard, plastic and moist. \\
\hline & 13.0 & & & Auger and split spoon refusal. \\
\hline 13.0 & 18.2 & & & *Limestone, hard drilling. \\
\hline 18.22 & 23.5 & & & Limestone, hard. \\
\hline 23.5 & 24.0 & & & Limestone, shaley, soft. \\
\hline 24.0 & 40.6 & & & Limestone, hard. \\
\hline 40.65 & 50.0 & & & Limestone, shaley, hard and soft. \\
\hline 50.05 & 55.0 & & & Limestone, hard. \\
\hline 55.05 & 56.8 & & & Limestone, hard. \\
\hline 56.85 & 57.3 & & & Limestone, shaley, soft. \\
\hline $57.3 t$ & 65.0 & & & Limestone, hard. \\
\hline 65.07 & 73.0 & & & Limestone, hard. \\
\hline & 73.0 & & & Total Depth \\
\hline & & & & *No detailed lithologic log could be provided \\
\hline & & & & from $13.0^{\prime}$ to $73.0^{\prime}$ due to use of a contain- \\
\hline & & & & ment box. \\
\hline & & & & \\
\hline & & & & \\
\hline & & & & \\
\hline & & & & \\
\hline & & & & \\
\hline
\end{tabular}




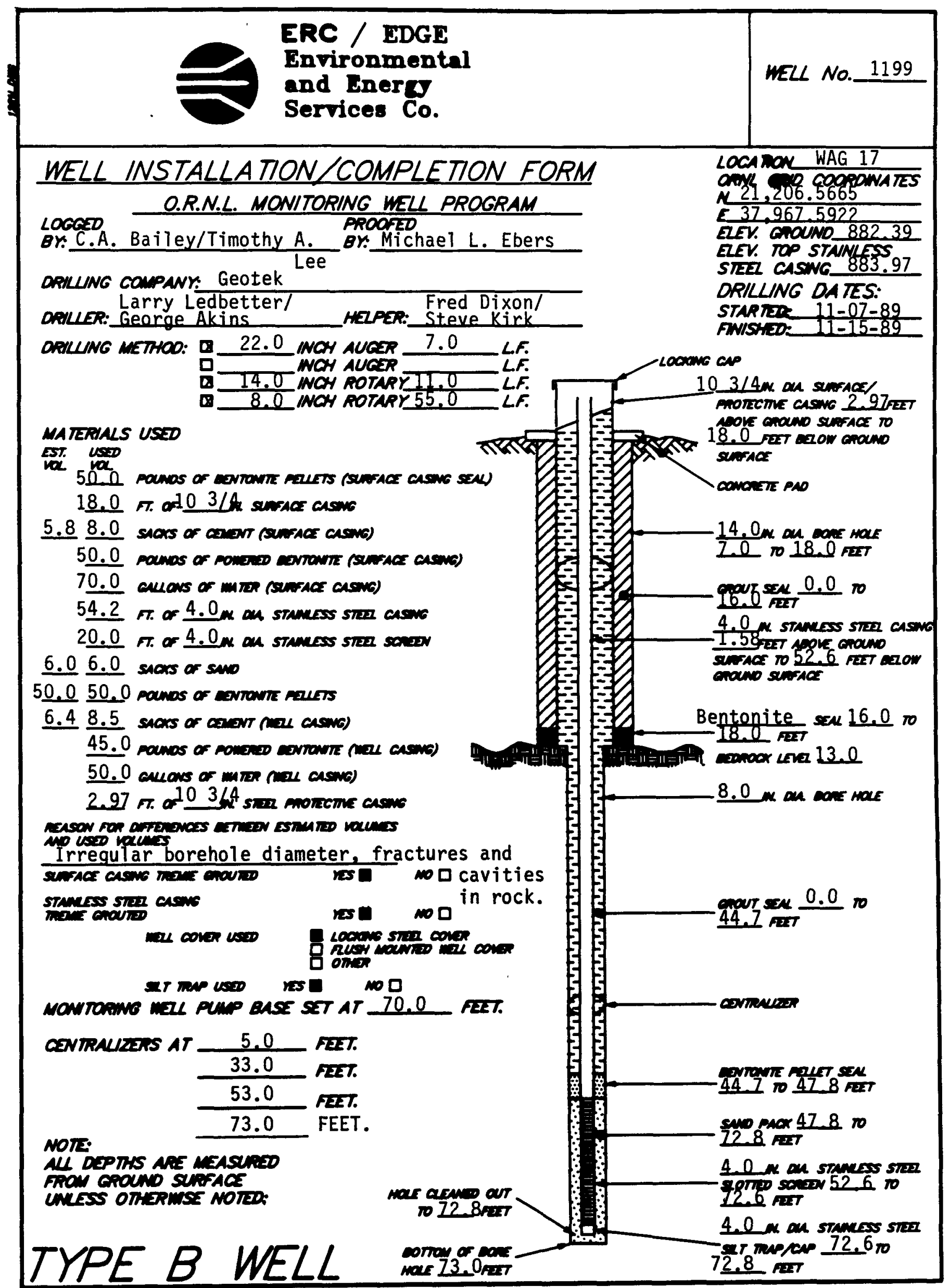

PACE 12 or 20 


\section{MONITORING WELL MATERIALS \\ CERTIFICATION}

\begin{tabular}{|c|c|c|}
\hline ITEM/MATERIAL & DATE USED & BATCH NUMAER \\
\hline SANO & $11-15-89$ & 1 \\
\hline \multirow{2}{*}{ BENTONITE } & $11-09-89$ & 1 \\
\hline & $11-15-89$ & 3 \\
\hline (PREPACKACED $\quad$ D $\left.\begin{array}{ll}\text { YES } \\
\text { NO }\end{array}\right)$ & $11-15-89$ & 2 \\
\hline (PREPACKACED $\left.\quad \begin{array}{c}\text { MES } \\
\text { NO }\end{array}\right)$ & $11-15-89$ & 2 \\
\hline STAINLESS STEEL CENTRALIZERS (PREPACKAGED $\left(\begin{array}{l}\text { YES } \\
\text { NO }\end{array}\right.$ & $11-15-89$ & 2 \\
\hline (PREPACKAGED D $\mathrm{MES})$ & $11-15-89$ & 2 \\
\hline (PREPACKAGED 0 i nOS & $3-30-90$ & 5 \\
\hline \multirow{2}{*}{ GROUT } & $11-09-89$ & 2 \\
\hline & $11-15-89$ & 2 \\
\hline MELL COVERS & $11-15-89$ & 3 \\
\hline SURFACE CASNGG & $11-09-89$ & 3 \\
\hline
\end{tabular}

COMMENTS:

D. Chanleosute 3-30-90

D. Charles Lytle

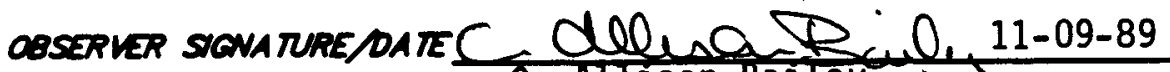
द. Altison Bailey 


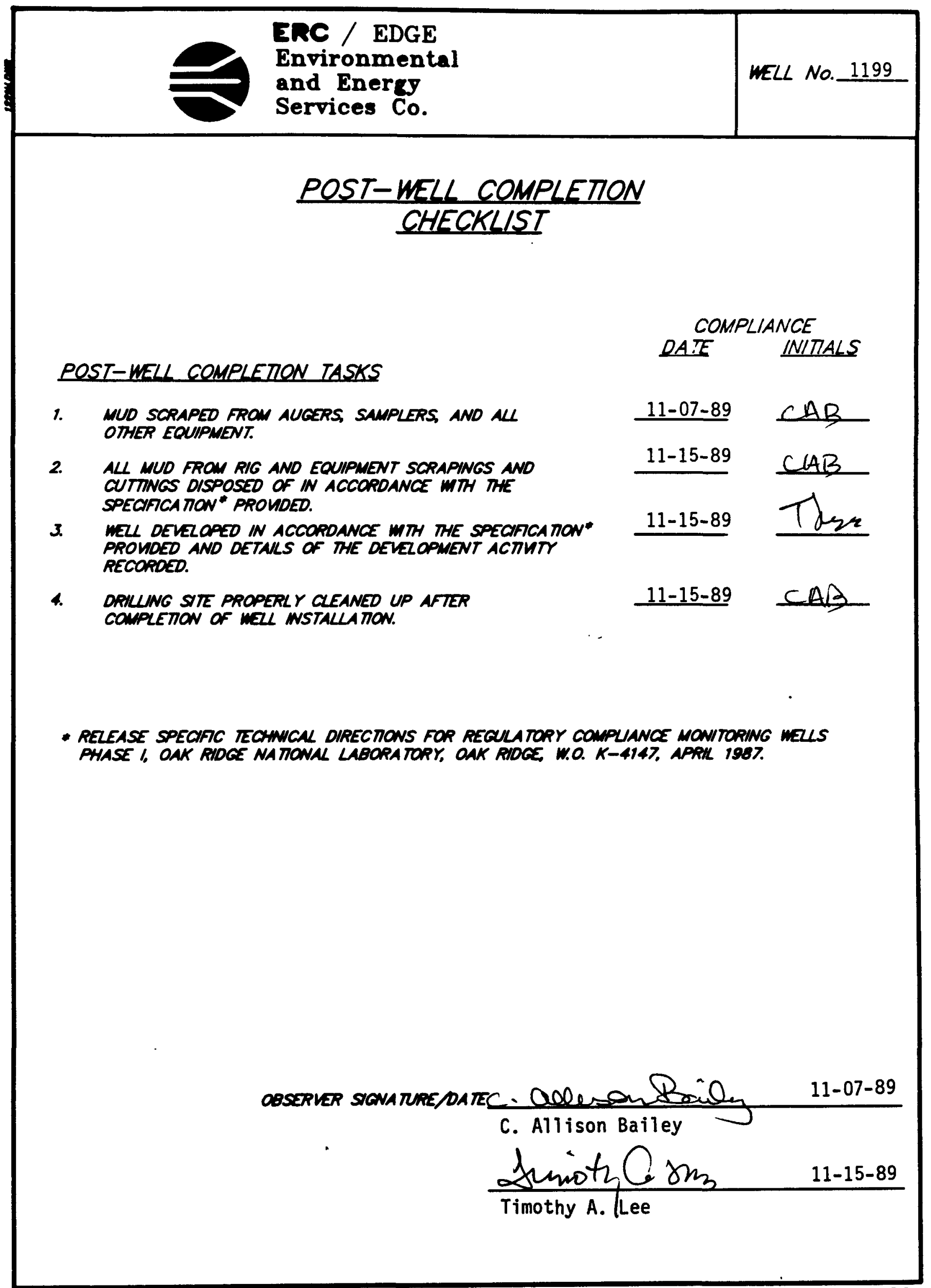

PACE 14 or 20 


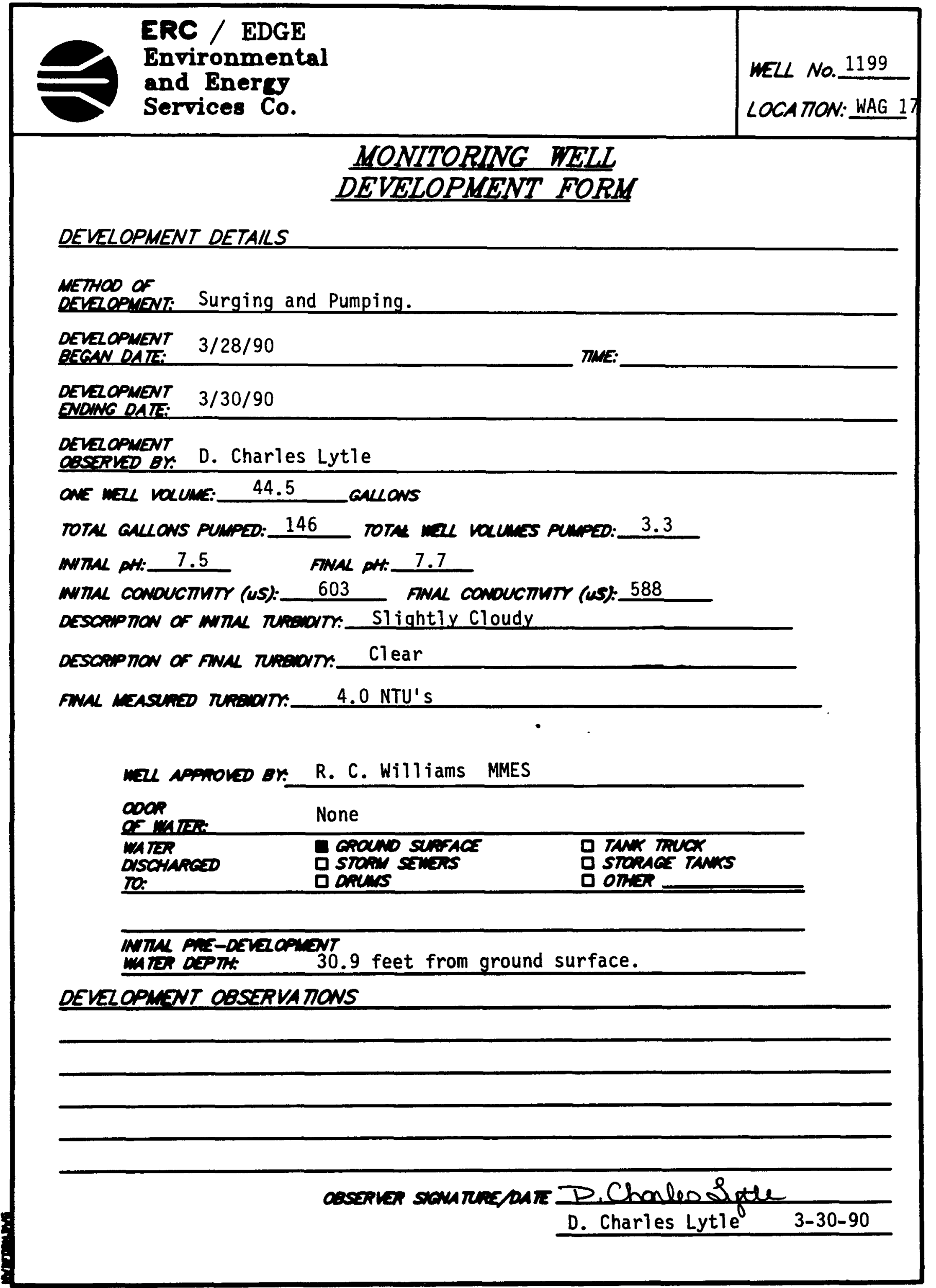




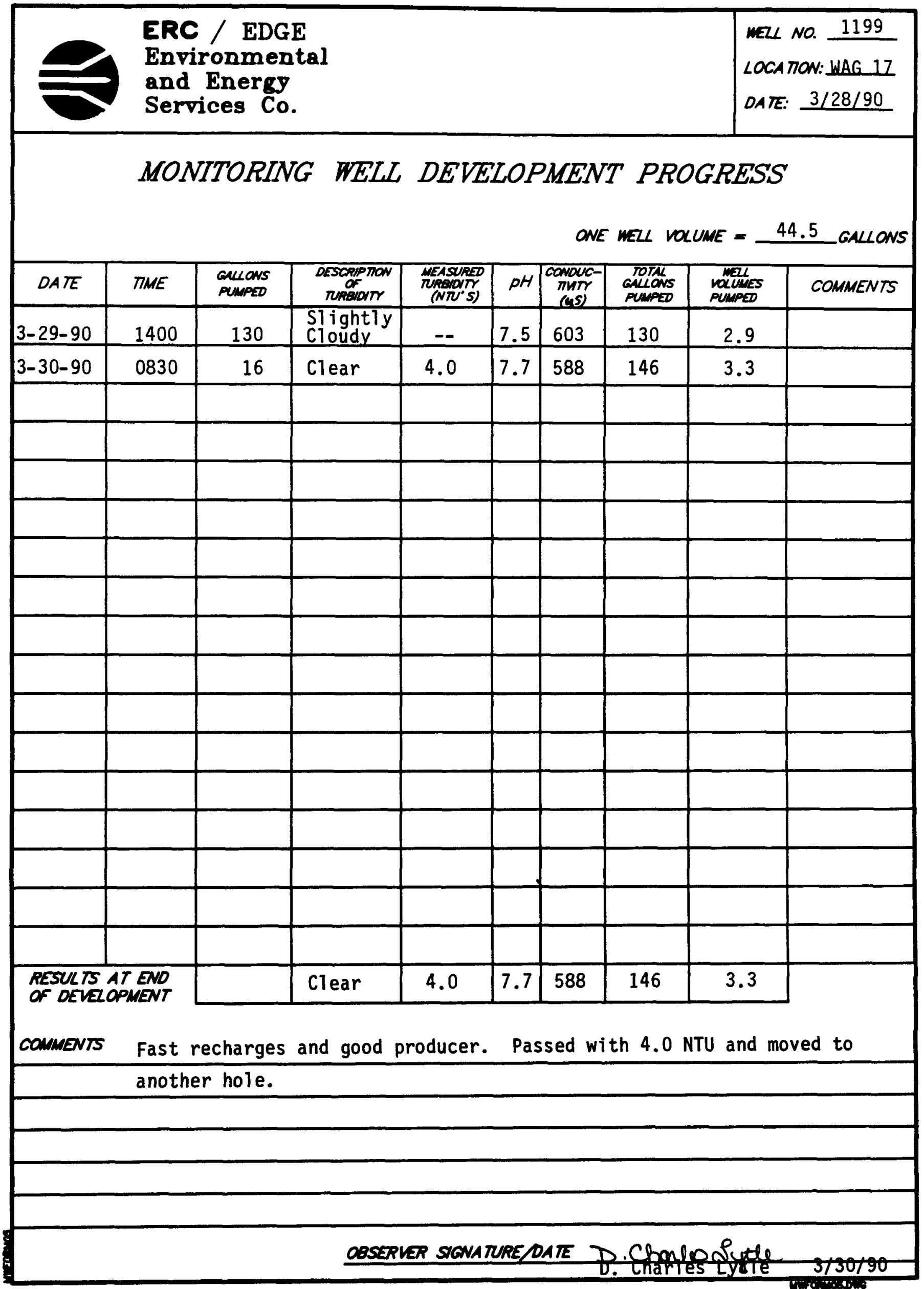

PAGE 16 of 20 


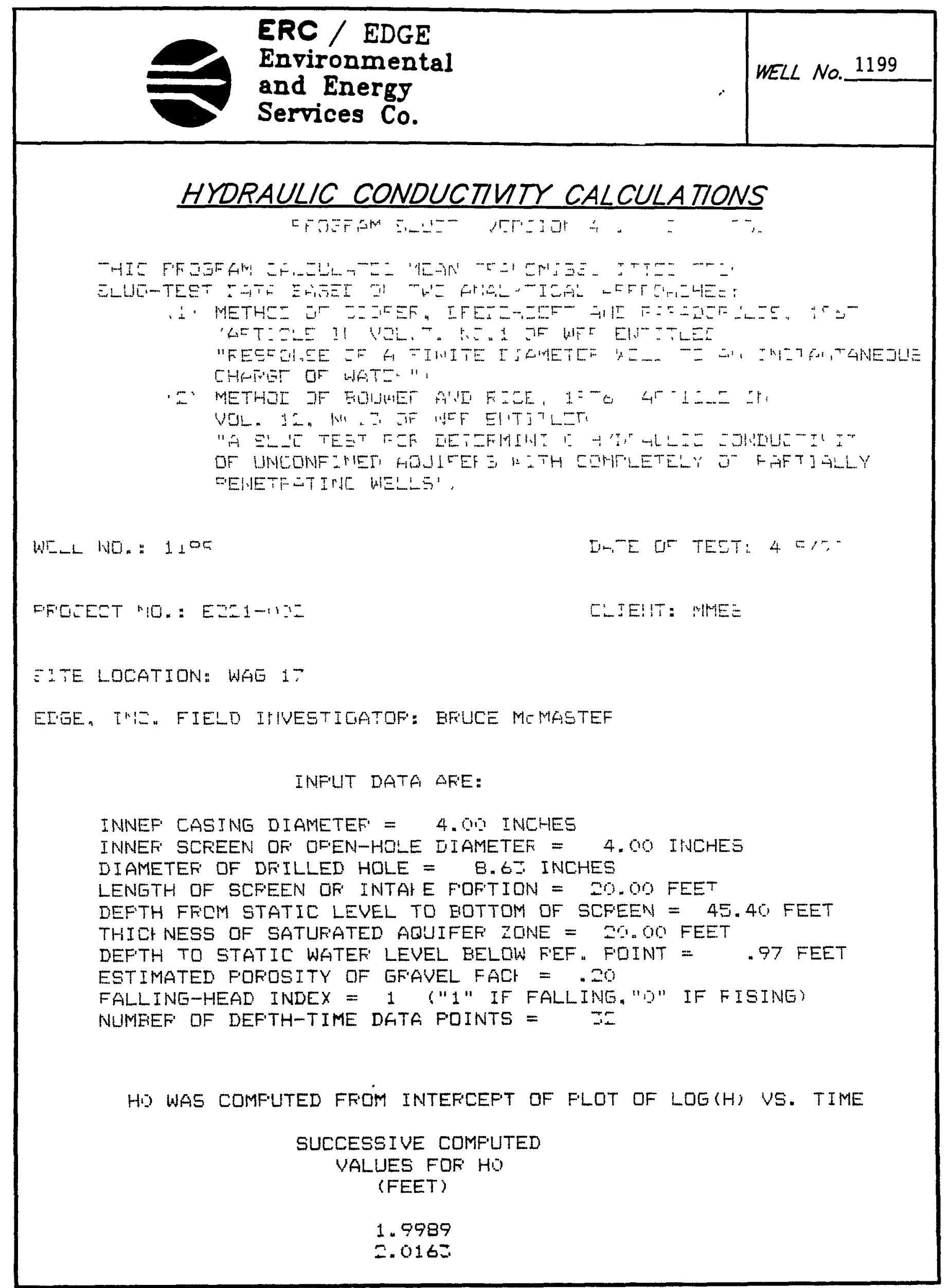

PAGE 17 of 20 


\section{HYORAULIC CONDUCTIVTY CALCULATIONS}

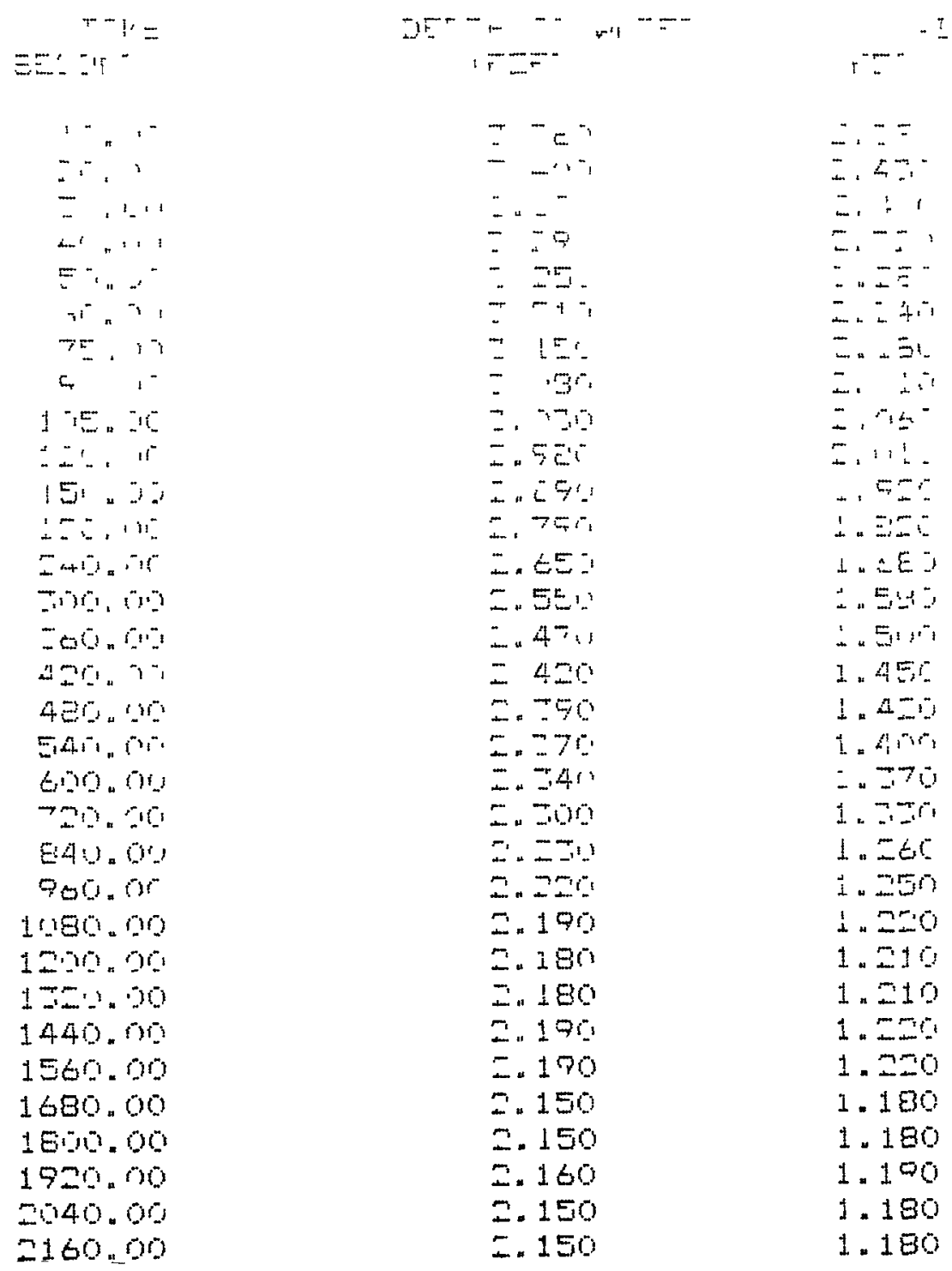

****************************************************************************

METHOD OF BOUWEF' AND FIICE

COMFUTED FESULTS USING DIAMETEF OF DFILLED HOLE:

$$
\text { FEFMEAEILITY }=8.87 E-07 \mathrm{FT} / \text { SECONDS }=2.70 \mathrm{E}-05 \mathrm{CW} / \mathrm{SECI}
$$

$\ldots$ TFANSMISSIVITY $=1.77 E-05$ FT**2/SECONDS

COMFÜTED FESULTS USING DIAMETEF DF CASINE AND SCFEEN:

FEFMEAEILITY $=1.05 E-06 \mathrm{FT} / \mathrm{SECONDS}=3.20 \mathrm{E}-05 \mathrm{cM} / \mathrm{SEC}$

TFANSMISSIUITY $=2 . \overline{10 E-O S ~ F T * * 2 / S E C O N D S ~}$ 


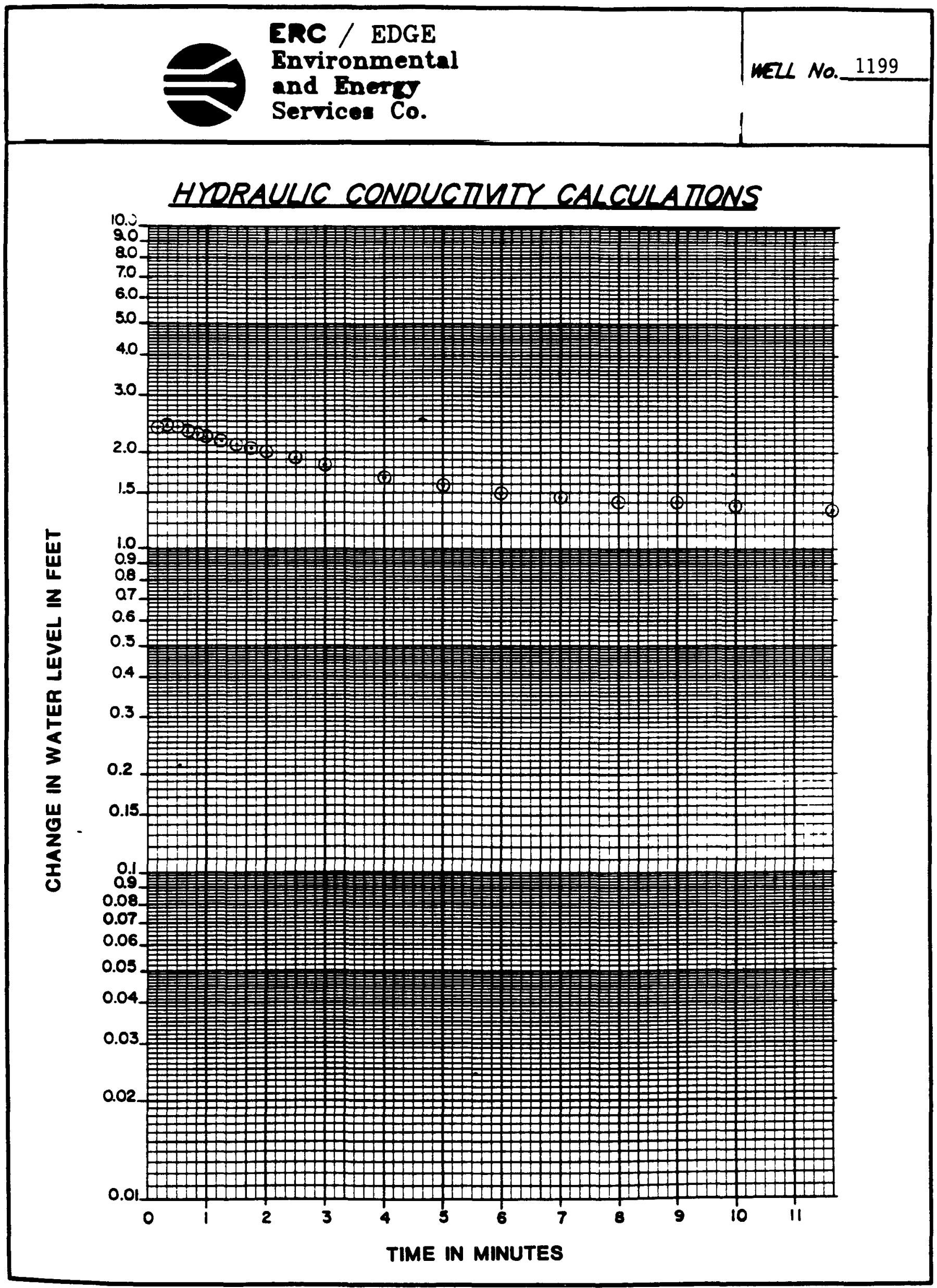

PACE 19 of 20 


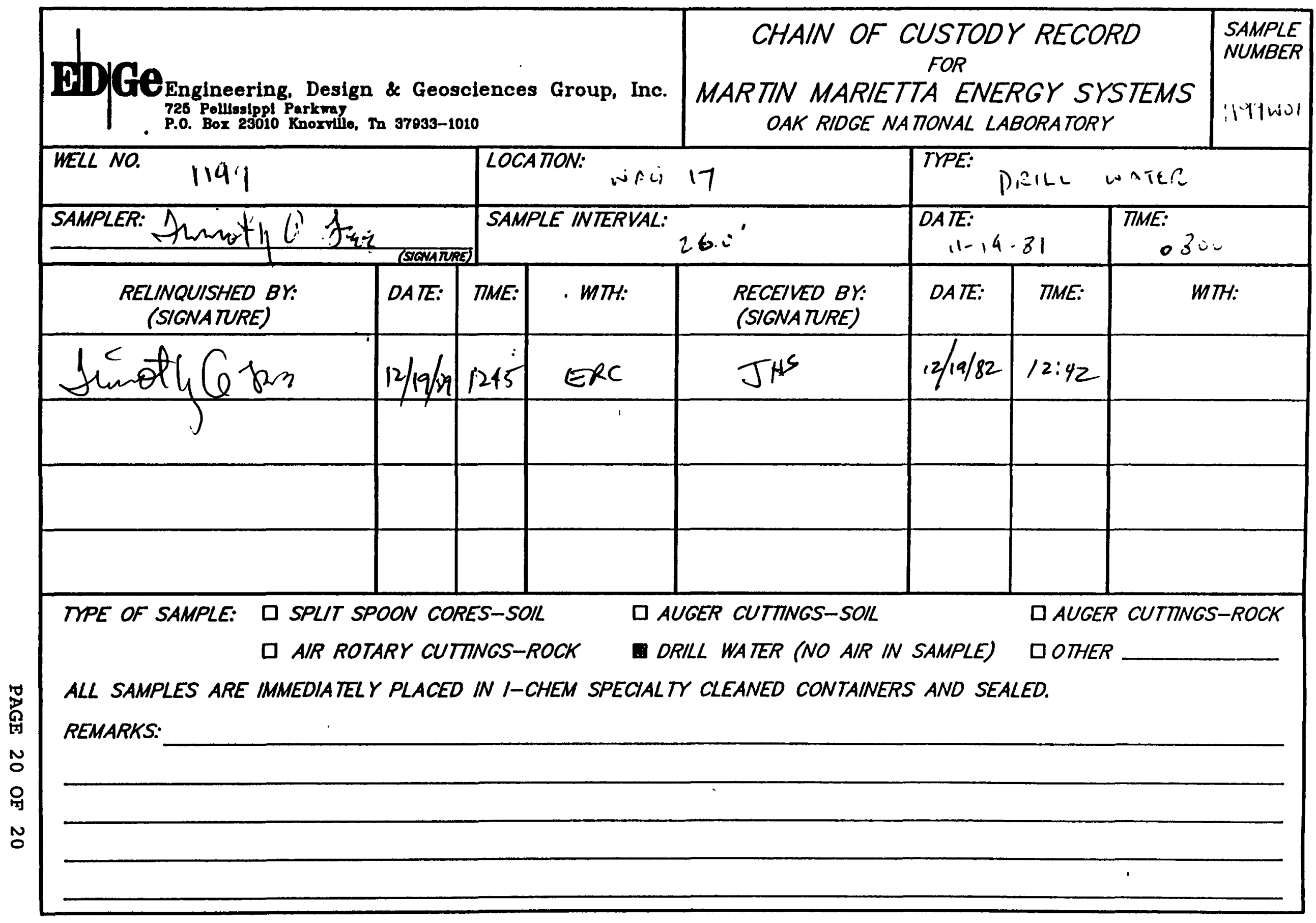




\subsection{General Information}

\subsection{Del1 Location}

Monitoring well number 1200 is located in WAG 17 . It is located in the southwest corner of the parking lot, approximately $250^{\prime}$ southwest of Bldg. 7013. The location is shown on ORNL drawing number C3E20004A075. Survey coordinates for this well are $N 21,339.1837$, E 36,317.7933 $(\mathrm{X}-10 \mathrm{grid})$ or latitude $35^{\circ}-55^{\prime}-59^{\prime} .19^{\prime \prime}$ and longitude $84^{\circ}-18^{\prime}-$ $02.88^{\prime \prime}$. Coordinate data were provided by Martin Marietta Energy systems. The method used for conversion from $x-10$ grid to Tennessee-Lambert state Plane coordinates came from the publication "Tennessee Valley Authority Data Services Branch and Mapping Services Branch, Oak Ridge, Tennessee, DOE Plant Control, November 6, 1985, Field Book: Ess-3115, pp. 1-20." The latitude and longitude were calculated by Adams Craft Herz Walker Engineering, Inc., using methods from the U.S. Coast and Geodetic Survey Publication 62-4, "State Plane Coordinates by Automatic Data Processing."

\subsection{Dril11ng Informatlon}

Well number 1200 was drilled by Geotek Engineering Company. A Schramm Air Rotary rig was used to drill this boring for monitor well installation under the operation of George Akins with the assistance of steve Kirk. Drilling commenced on 118-89 and was finished on 11-13-89. Paragraph 2.4.1 includes a detailed discussion of the well installation and a well schematic is included on the well installation/completion form. A synopsis of the drilling activity follows. This information was typed directly from field notes and was edited only when necessary for clarification. 
11-8-89: The Schramm was mobilized to the staked location and set up on plastic. Split spoon samples were taken from the surface to 4.7 feet. The boring was augered with a 6" auger to refusal at 4.7 feet. The boring was then augered with a 14" auger to 3.3 feet. The rig was moved off the hole.

11-9-89: Set 3.3 feet of $103 / 4^{\prime \prime}$ diverter casing and grouted with 3 sacks cement.

11-10-89: Moved Schramm to location and drilled from 4.7' to $35.0^{\circ}$ with $77 / 8^{\prime \prime}$ air rotary tri-cone using the containment box.

11-13-89: Continued drilling from 35.0' to $40.0^{\prime}$ with a 7 $7 / 8^{N}$ air rotary tri-cone using the containment box. Had 4 feet of water in hole after 1 hour. Install-ed $2^{*}$ casing, screen, sand pack and bentonite seal. Grouted annulus with 6 sacks of cement.

This well was logged by the EDGe Group of ERC Environmental and Energy Services Co., Inc., hydrogeologist Timothy A. Lee. All well construction materials and supplies were from Martin Marietta Energy Syetems approved batches. The batch origin of individual items is shown on the included Monitoring Well Materials Certification form. 
2.0 Technical Information

\subsection{Decontamination Procedures}

The drilling rig, down hole tools, surface casing, stainless steel screen, stainless steel casing, centralizers, and stainless steel silt trap underwent the cleaning decontamination procedures outlined in the drilling specifications (Release Specific Technical Directions for Regulatory Compliance Monitoring Wells Phase 1, Oak Ridge National Laboratory, Oak Ridge, W.O. K-4147, April 1987, pgs. 2-4). A checklist of the cleaned materials is included with this data package.

\subsection{9}

WAG 17 encompasses approximately 23 acres in Bethel Valley, which is in the Valley and Ridge Physiographic Province of East Tennessee. WAG 17 is underlain by the middle Ordovician Chickamauga Group consisting mainly of limestone and siltstone. The Chickamauga Group consists of eight units, designated by letters A through H (stockdale, 1951). WAG 17 is underlain by units $E, F, G$ and $a$ portion of $H$. These units consist of thin bedded nodular limestone with clay and shale partings. Portions of units $H$ and $F$ consist of calcareous elltstone alternating with beds of olive gray to maroon shale. The regional strike $1856^{\circ}$ northeast and has a moderate dip of $30^{\circ}$ to $40^{\circ}$ southeast. 


\subsection{Bample Collection}

One soil sample was collected during drilling, placed in an I-CHFM specialty cleaned glass container, sealed and submitted to Sample Receiving, Analytical Chemistry Division, Bldg. 4500s, ORNL. A chain of custody form for this sample is included with this data package. Soil sample 1200501 was collected in the split spoon interval from $1.4^{\prime}$ to $1.7^{\prime}$ on 11-8-89.

A drill water sample was collected from the water pump on the drill rig on 11-10-89. Analytical results for the soil and water samples described above can be obtained from the Remedial Action Program data base at ORNL.

A bulk density soil sample was collected from the split spoon sample interval from 1.4' to 1.7'. The sample was measured and weighed, and a bulk density of $2.18 \mathrm{grams} / \mathrm{cm}^{3}$ was calculated.

The Schramm air rotary $\mathrm{rig}^{\prime} \mathrm{s}$ compressed air was sampled with a cloth eilter inserted between drill rods on 11-13-89. The sample was examined with an ultraviolet light for the presence of hydrocarbons. The filter showed no evidence of hydrocarbone.

\subsection{Ineta11ation and Doveloprent}

\subsubsection{Ingtalintion}

This was a type D well. A 6-inch diameter boring was split spooned from ground surface to refusal (4.7 feet). The air rotary method was required to complete the boring to the 
specified total well depth. Therefore, a 14 inch diameter boring was augered from ground surface to 4.7 feet and a 10 3/4 inch diverter casing was installed and grouted. A 7 7/8-inch diameter boring was then drilled with an air rotary tricone roller bit from 4.7 to 40.0 feet. A 2-inch diameter stainless steel screen with a 0.2 -foot bottom silt trap/cap was installed from 29.8 to 40.0 feet. A 2 -inch diameter stainless steel casing was installed above the screen at 29.8 feet and extended 2.15 feet above ground surface. A sandpack was then tremied into the annular space from 28.1 to 40.0 feet, with a 1.6-foot bentonite pellet seal poured into the annular space above the sandpack from 26.6 to 28.1 feet. The annular space from the top of the bentonite seal to the surface was tremie-grouted with a cement/bentonite slurry. A detail of the well is included on the well installation/completion form.

\subsubsection{Well Development}

Well number 1200 was developed to remove drill cuttings, silt, and other fines. The monitoring well was developed using a Geoguard pump with an air compressor. All pumps were cleaned prior to use according to specified cleaning procedures (see Paragraph 2.1). The well was developed until a measured total of 177 gallons of water had been evacuated and the clarity of the discharge water was approved by the company representa-tive. The final turbidity value measured at completion was 1.0 NTU. A development form showing the exact method of development and other pertinent data is appended. 
After the well was developed, a Geoguard Model No. 5614 dedicated monitoring well pump was installed on 4-3-90 at a depth of 38.25 feet below ground surface. These pumps are decontaminated at American sigma and are sent prepackaged. A copy of the pump certification is kept on file at ORNL.

\subsection{Eydraulio Conductivity Testing}

Well number 1200 was tested for the determination of hydraulic conductivity of the aquifer in the vicinity of the well screen. This was accomplished by instantaneously adding a known quantity of water to the monitoring well and measuring the recovery of the water level over time. The changing water levels were measured using a Druck Model DPI600 pressure transducer. The hydraulic conductivity value of $2.25 \times 10^{-5} \mathrm{~cm} / \mathrm{second}$ (shown as permeability on the hydraulic conductivity calculations printout attached) was calculated using the Bouwer and Rice method. A computer printout of the hydraulic conductivity calculations is included in this data package. 


\section{PRE-DRILLING CHECKLIST FOR MONITORING WELLS}

RRE-DRILLNG TASKS

1. EXCAVTON PERMIT OBTAINED

2. ALL EQUIPMENT HAS BEEN CLEANED BEFORE DRILUNG.

30. SCREEN AND CASING HAVE BEEN WASHED, STEAMED, RINSED WIH DE-IONIZED OR DISTLLED WATER, RINSED WTH ISOPROPN ALCOHOL. WRAPPED WTH PROTECTIE COVERING AND STORED OFF THE GROUND.

36. PRE-PACKAGED SCREENS, CASING AND CENTRALIZERS MERE USED.

4. WORK AREA FOR SAMPLE EXAMINATION COVERED WTH CLEAN POL YETHIRENE.

5. CLEAN KNIVES, QLOVES, SAMPLE JARS AND LABELS ON HAND.

6. POLYETHIENE COVER IN PLACE OVER HOLE.

7. ARR ROTARY COMPRESSED ANR SAMPLED.

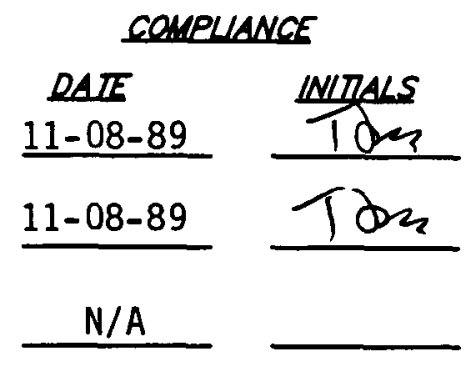

11-13-89 I $2 m$ 11-08-89 T th 11-08-89 I I $_{3}$ 11-08-89 T2m 11-13-89 TD23

RESULTS:

ADOITONAL NOTES/OBSERVATIONS:

osserver sovaturepate fhmooth Girm 11-13-89 


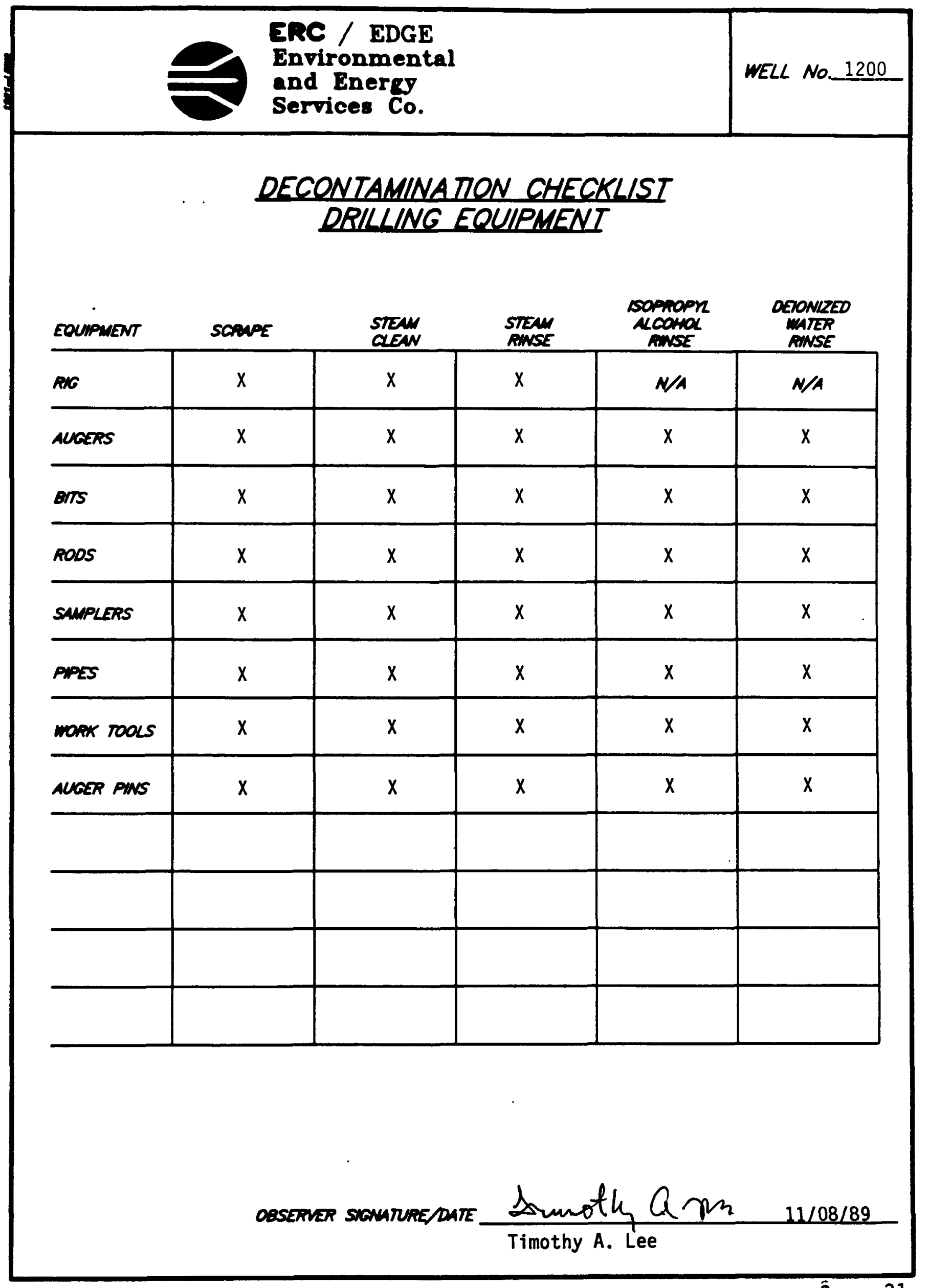




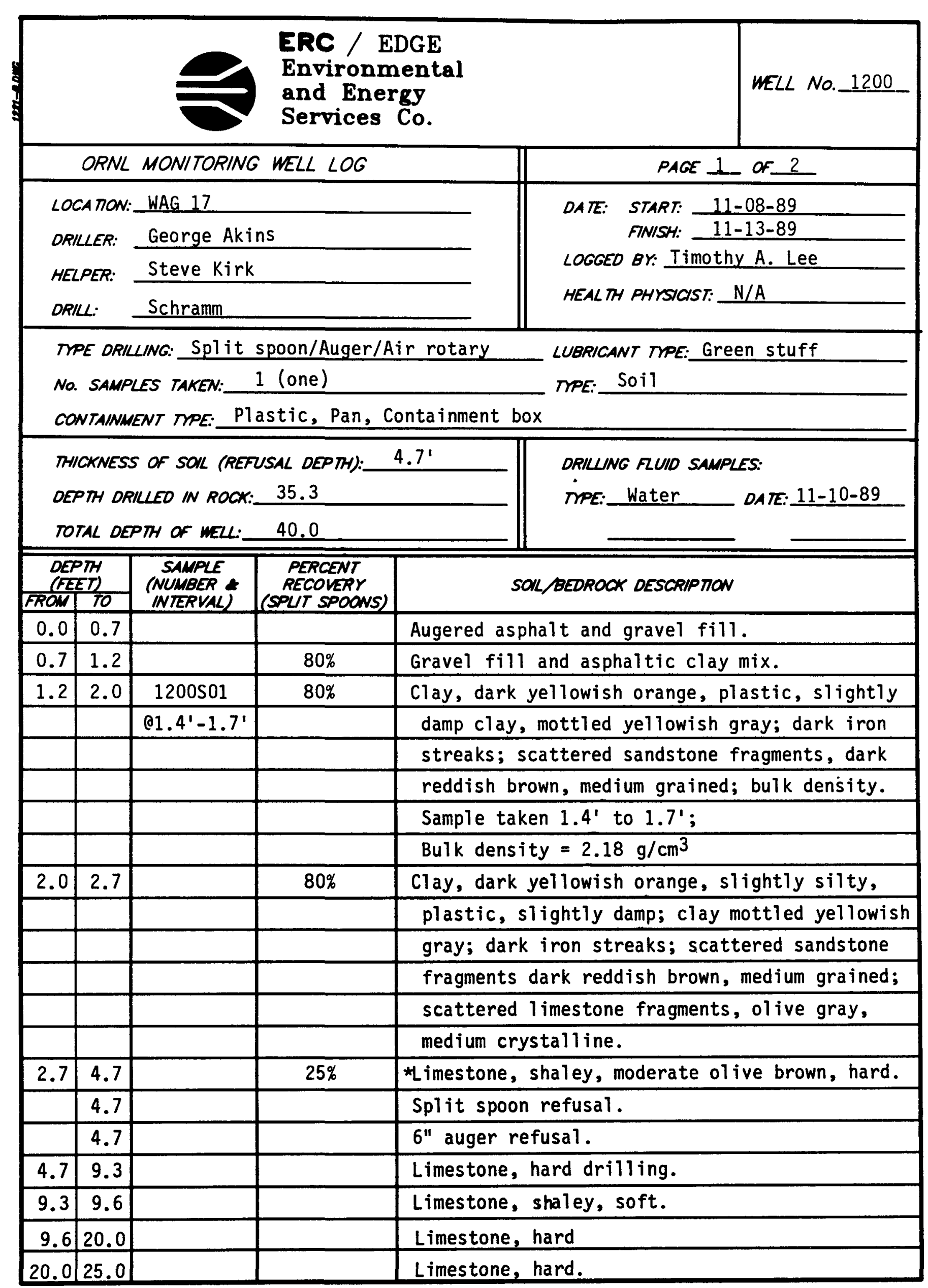




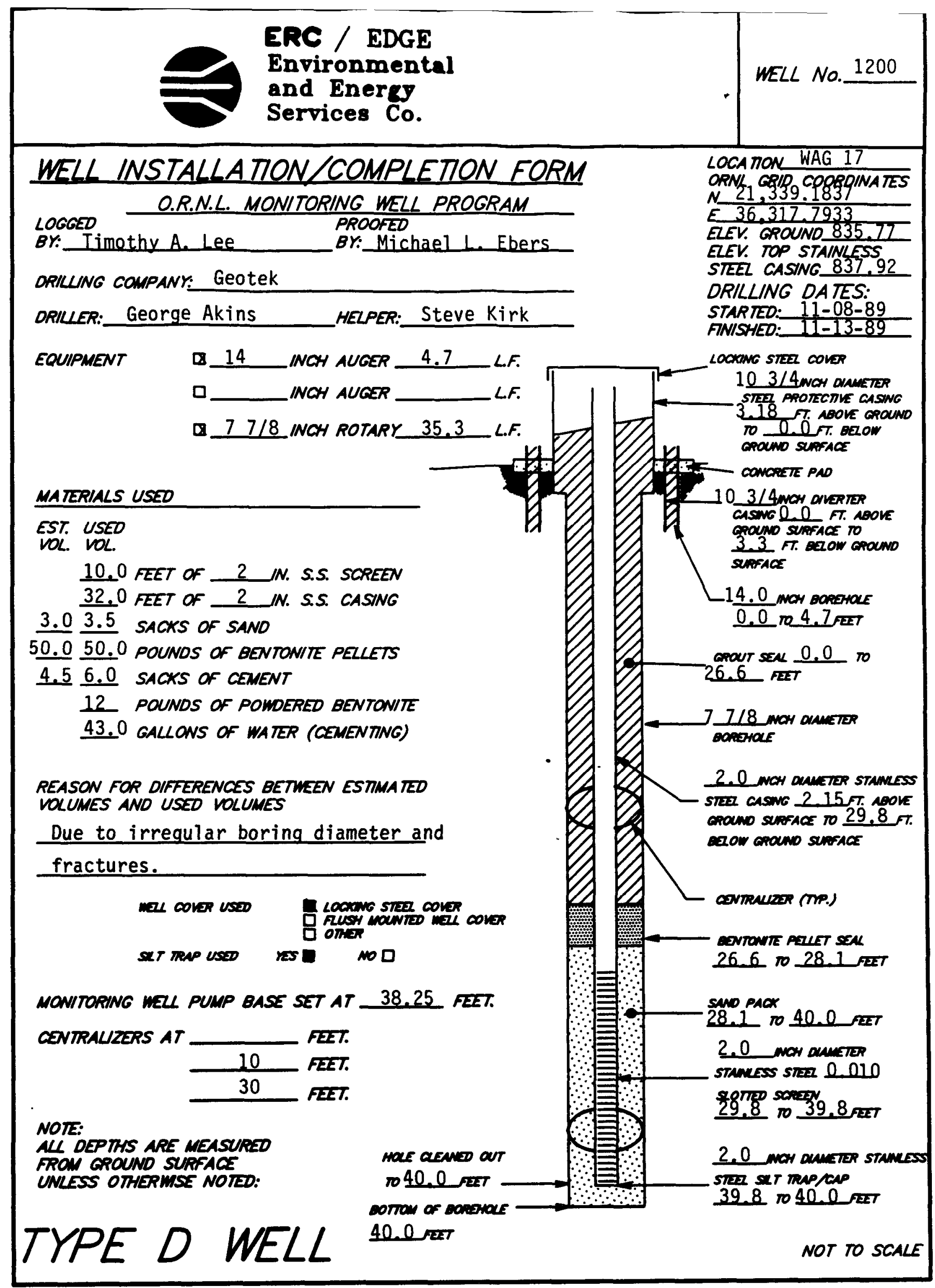

PAGE 11 of 21 


\section{MONITORING WELL MATERIALS CERTIFICA IION}

ITEM/MA TERIAL DATE USED BATCH NUMEER

SANO

BENTONITE

Pellets

Powder

\begin{tabular}{|c|c|c|c|}
\hline STAINLESS STEEL SCREEN & (PREPACKAGED $\mathrm{Q}$ NOS & $11-13-89$ & 2 \\
\hline STANLESS STEER CASNG & (PAEPACKACED D & $11-13-89$ & 2 \\
\hline STAINLESS STEEL CENTRALIZERS & $\left(\begin{array}{lll}\text { PAEPACXACED } & \text { DOS } \\
\text { NO }\end{array}\right)$ & $11-13-89$ & 2 \\
\hline STAINLESS STEEL CAPS & (PADPACKACDD $\left.0 \begin{array}{c}\text { YES } \\
\text { NO }\end{array}\right)$ & $11-13-89$ & 2 \\
\hline MONTORNG WELL PUMP & $\left(\begin{array}{lll}\text { PREPACXNAGD } & \text { Q } \\
\text { NOS }\end{array}\right)$ & $4-03-90$ & 5 \\
\hline \multirow{2}{*}{ GROUT } & & $11-13-89$ & 2 \\
\hline & $\dot{-}$ & & \\
\hline \multicolumn{2}{|l|}{ MELL COVERS } & & \\
\hline SURFACE CASING & & $11-08-89$ & 2 \\
\hline
\end{tabular}

COMMENTS:

coserver sowaturepare Sunnotly G-8m 11-13-89

Timothy A. Lee

D. Chanles ofude 4-03-90

D. Charles Lytte 


\section{POST-WELL COMPLETION CHECKLLST}

\section{POST-WEL COMPLEIION TASKS}

COMPLIANCE

$$
\text { DATE INITALS }
$$

1. WLO SCRAPED RROW AUGERS SMMPLERS ANO NL OTHER EOUIPIENT.

$11-08-89$

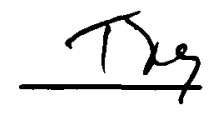

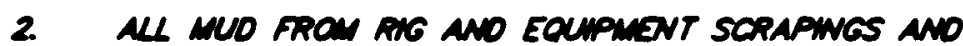
OUTIMNOS OSPPOSZD OF WN ACCOROANCE WITH THE SPECACA HON PROWOED.

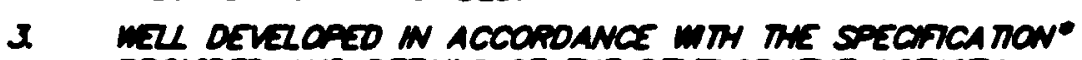
PROMOED ANO DETAKS OF THE DEVZOPWENT ACTUTH RECOROED.

4. OAKLNG STI PROPERK Y QEANED UP NTER complemon of well WSTALA

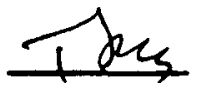

4-04-90 DC\&

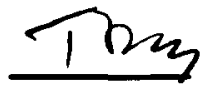

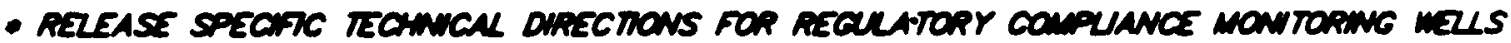

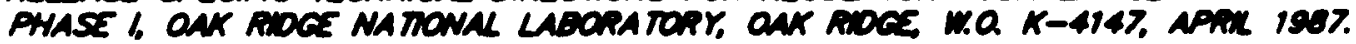

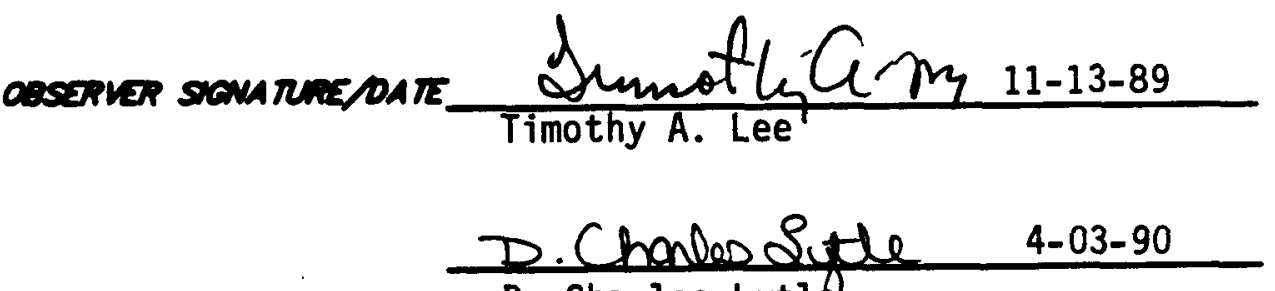

D. Charles Lytle 
ERC / EDGE

Environmental

and Energy

WELL No._1200

Services Co.

DEVELOPMENT DETAILS

METHOD of

DEVEROPMENT: Surging and Pumping

DEVELOPMENT

BEGAN DATE:

$3 / 28 / 90$

TME:

DEVEZOPNENT $\quad 4 / 03 / 90$
ENDING DATE:

DEVELOPNENT

OBSERVED BY:

D. Charles Lytle

ONE WEL VOLUNE: 10.0 CNLONS

TOTAL GALLONS PUMPED: 177 TOTA MEL VOLUMES PUMPED: 17.7

INITAL DH: 7.5 FINAK PH: 7.2

INIMAL CONDUCTUT (uS): 811 FNAL CONDUCTUTY (uS): 772

DESCRIPTION OF INITAL RUREOIT:_ Slightly Cloudy

DESCRIPTION OF FNAL RUREIOITY Crystal Clear

FNAL MEASURED TURBOIT:_ 1.0 NTU'S

WZU APPROVED BY. R. C. Williams MMES

oods

Qf MATR. None

MATER GROUNO SURFACE

OISCHARCD O STOPW SEMBRS

ro:

口 ORCMIS

口 TANK TRUCK

口 STORAGE TANKS

口 OTHER

INITAL PAE-DEVELOPIENT

WATER DEPTH: 6.3 feet from ground surface.

DEVELOPMENT OBSERVATIONS

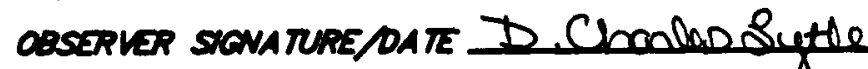

D. Charles Lyt Pe

$4 / 03 / 90$

PACE 14 of 21 


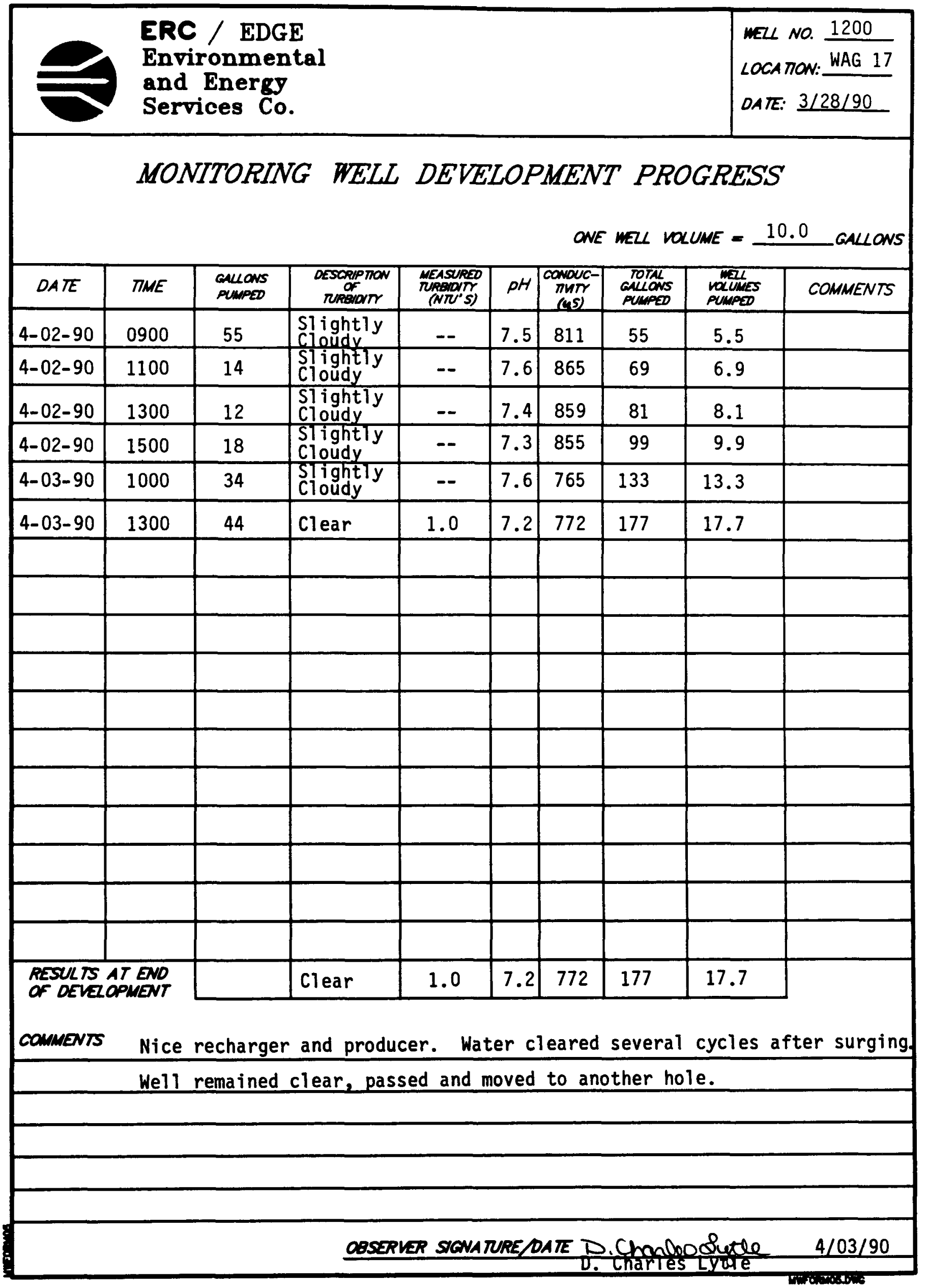




\section{HYORAULIC CONDUCTIVTY CALCULATIONS}

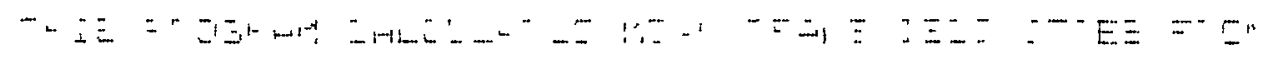

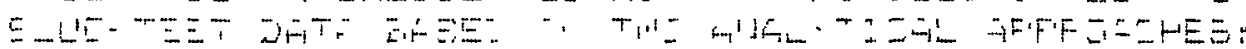

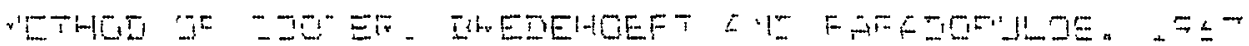

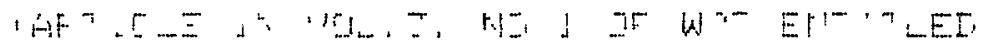

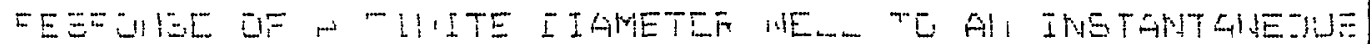
Cr:E

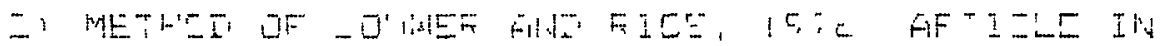

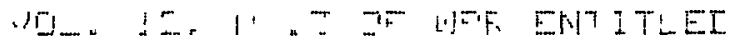

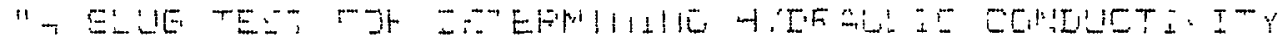

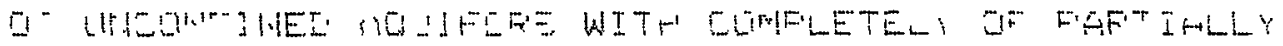

ER!E-

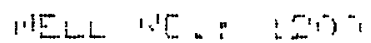

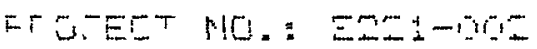

GITE LOCATION: WAE 1 ?

EDGE, INC. FIELD INVESTIGATOF: EFILCE MCMASTEF

INFUT DATA ARE:

INNER CAEING DIAMETEF $=2.00$ INCHES

INNEF SCFEEN OF OFEN-HOLE DIAMETEF $=2.00$ INCHES

DIAMETEF OF DFILLED HOLE $=0.75$ INCHES

LENETH OF SCFEEN OF INTAYE FOFTION $=10.00 \mathrm{FEET}$

DEFTH FFOM STATIC LEVEL TO EOTTOM OF SCFEEN = $.4 .70 \mathrm{FEET}$

TH.JCI NESS OF SATUFATED AQUIFEF ZONE $=10.00$ FEET

DEFTH TO STATIC WATEF LEVEL BELOW FEF. FOINT $=1.00$ FEET

ESTIMGTED FOFOSITY OF GFAVEL FACF $=.20$

FALLING-HEAD INDEX = 1 " 1 " IF FALLING, "O" IF FISINE?

NUMEEF OF DEFTH-TIME DATA POINTS $=\quad I=$

HO WAS COMFUTED FFOM INTEFCEFT OF FLOT OF LOG(H) VS. TIME

SUCCESSIVE COMFUTED

VALUES FOF: HO

(FEET)

3.8895

5.9267 


\section{HYORAULIC CONDUCTIVTY CALCULATIONS}

$3=-8+2$

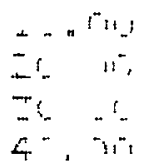

Er: :

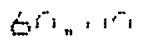

$-5, \cdots$

$r i, \log$

$1: 5.5$

$\because=3,13$

150.00

78040

240.00

=nin.

$=6 \% .05$

$4=5,6$

$4 \mathrm{CO}^{\circ} \mathrm{n}$

$540, \mathrm{~m}$

60\% .

$7=\mathrm{ar}$

840.0

760.0

$\pm 080.00$

$=200.00$

$1=20.00$

1440.00

1560.00

1680.00

1800.00

1920.00

2040.00

2160.00
$E I+T E$
$+E E$

$=-\cdots$

$=-\therefore$

$E=$

둗․

든.

E. =

E. :

4. C. C.:

1. $\vec{E}^{\top} \cdot$

- 205

ㄷ. 드으.

$\therefore, 4$

4.210

$\therefore$ ․․

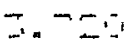

$\because E=0$

편.

I. Fo

$\because .270$

$=100$

$=00$

$=.850$

‥ 820

$=.760$

$=.660$

$=.560$

$2.5 \pm 0$

I. 470

I. 450

$=400$

I. .60

2. 25

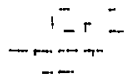

. $\equiv-{ }^{-}$

$-1-15$

I. 5.5

$4.4 E$

- 7 .

$4,-5$

$4 \quad 119$

다.

ㄱ.

$\exists-2$.

․ 5

$\because 20 \%$

$=. \pm 10$

$=e^{\circ}$

$=.75$

$\pm= \pm$

$=.45$

$2.26 n$

$=.270$

$=10 \%$

1. 095

1. 850

1. $8=5$

1.760

1.660

1.560

$1.5=0$

1.470

1. 450

1.400

$1 .=60$

1. $=5$ 
ERC / EDGE

Environmental

and Energy

Services Co.

HYDRAULIC CONDUCTIVTY CALCULATIONS

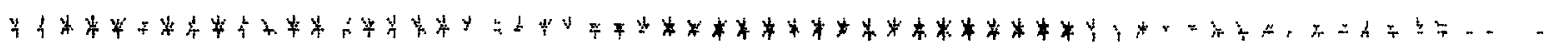

NETHES OF EDWUEF ANIT TIEE

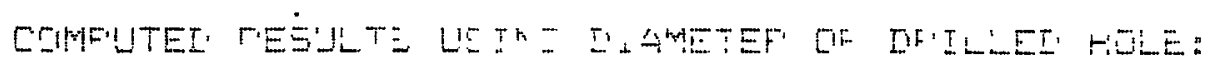

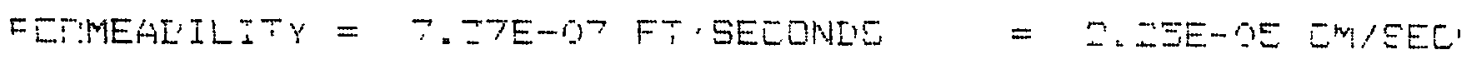

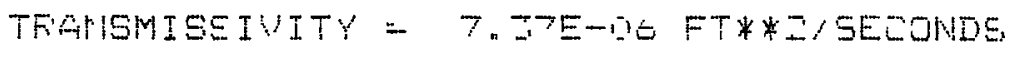

COMFUTED FEEULTS USING DIAMETEF OF CASING AND SCREEI!:

FEFMEAEILITY $=7.71 E-7$ FT/EECDNDS = $=2.96 E-05$ CM SEE

TFANSMISSIVITY $=9.71 E-06$ FT**2/SECONDS

PACE 18 of 21 


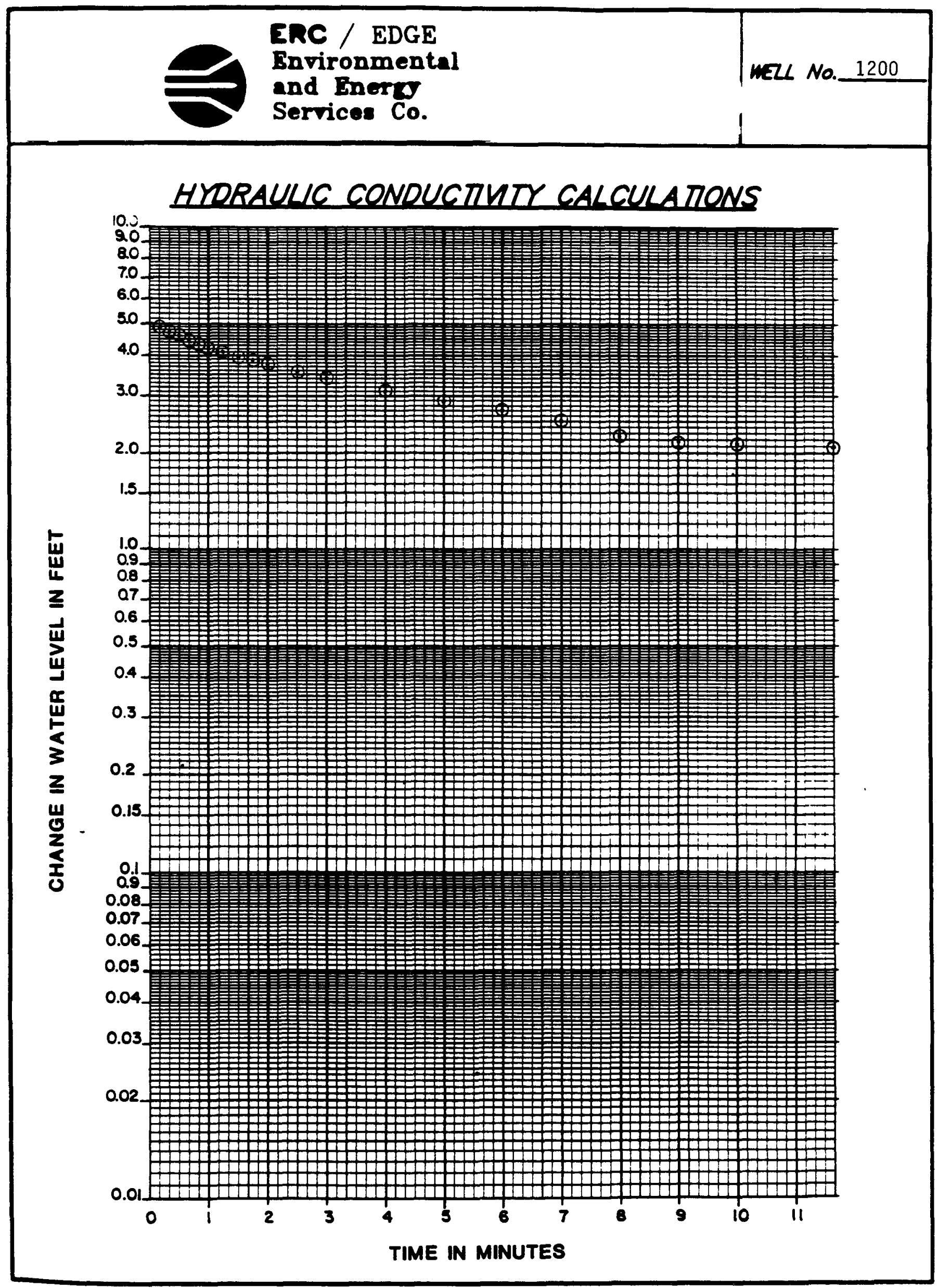

PACE 19 or 21 


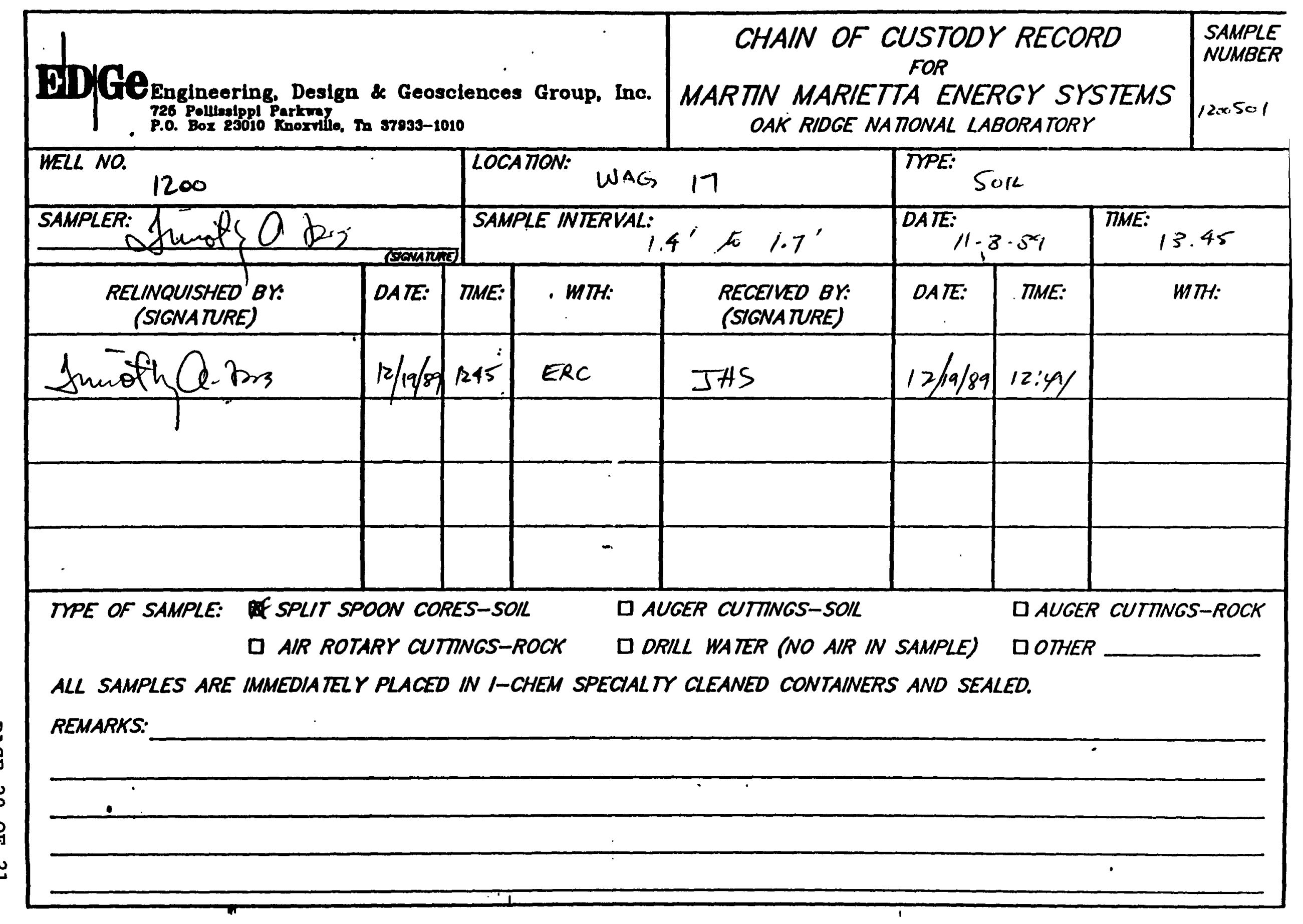




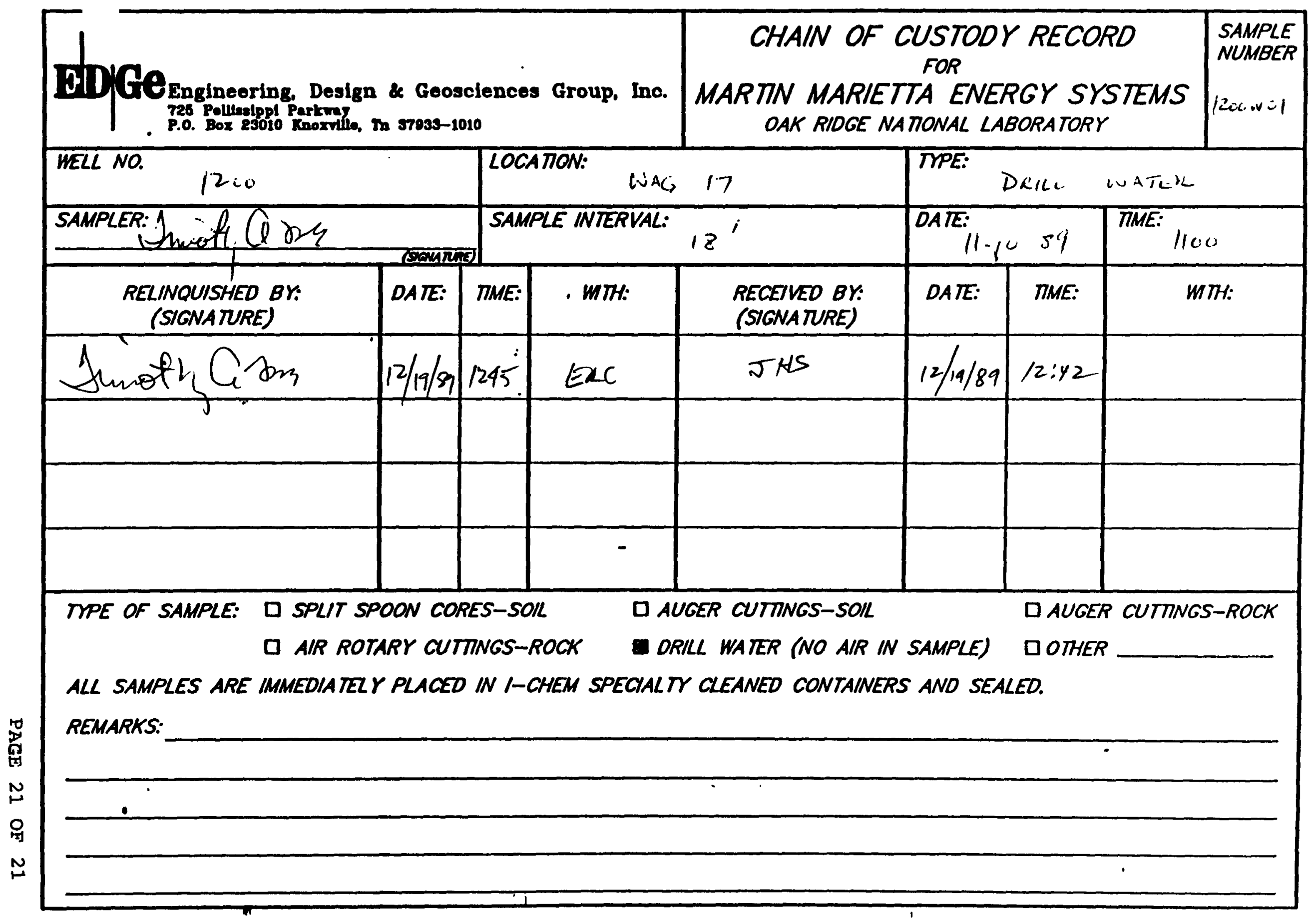


I

I

!

1 
1.0 General Information

1.1 well Location

Monitoring well number 1201 is located in WAG 17. It is located in the parking lot approximately 100 feet west of Bldg 7003. The location is shown on ORNL drawing number C3E20002A075. Survey coordinates for this well at $N$ $21,566.8925, \mathrm{E} 36,414.6397$ (X-10 grid) or latitude $35^{\circ}-56^{\prime}-$

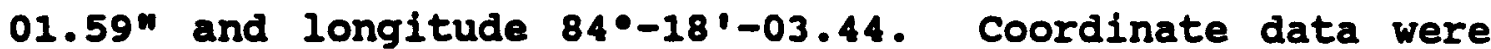
provided by Martin Marietta Energy Systems. The method used for conversion from $x-10$ grid to Tennessee-Lambert state Plane Coordinates came from the publication "Tennessee Valley Authority Data Services Branch and Mapping Services Branch, Oak Ridge, Tennessee, DOE Plant Control, November 6, 1985, Field Book: ESS-3115, pp. 1-20." The latitude and longitude were calculated by Adams Craft Herz walker Engineering, Inc., using methods from the U.S. Coast and Geodetic survey Publication 62-4, "State Plane Coordinates by Automatic Data Processing."

\subsection{Drilling Information}

Well number 1201 was drilled by Geotek Engineering Company. A schramm Rotadrill rig was used to drill this boring for monltor well Installation under the operation of George Akins with the aseletance of James Shelton. Drilling commenced on 11-30-89 and was finished on 12-7-89. Paragraph 2.4.1 includes a detalled discussion of the well installation and a well schematic is included on the well installation/completion form. A synopsis of the drilling activity follows. This information was typed directly from field notes and was edited only when necessary for clarification. 
11-30-89: The rig was mobilized to the staked location and set up on a sheet of plastic. The boring was augered with a $20^{\mathrm{N}}$ auger to refusal at 3.4 feet. Set 3.4 feet of $153 / 4$ inch decontanimated steel diverter casing and grouted it into place with 1 sack of cement. The rig was moved from the location.

12-4-89: The rig was mobilized to the location and set up on plastic. The boring was deepened from 3.4 feet to 24.8 feet using a $141 / 2$ inch air rotary tricone bit into the containment box.

12-5-89: The boring was deepened from 24.8 feet to 30.0 feet. Set 30.0 feet of $103 / 4$ inch decontanimated steel surface casing with Bentonite seal. The rig was moved from the location.

12-6-89: The surface casing was tremie grouted into place with 10 sacks cement.

12-7-89: The rig was mobilized to location and set up on plastic. The boring was deepened from 30.0 feet to 48.0 feet using a $7 / 8$ inch air rotary tricone bit into a containment box. Estimated total depth was to be 65.0 feet, however, a large volume of water was encountered at 43.0 feet. Therefore, a decision was made to complete it at 48.0 feet. stainless steel screen and casing were set with a sand peck and bentonite seal. The rig was moved from location. 
12-8-89: The casing was tremie grouted into place with 9.0 sacks cement.

This well was logged by the EDGe Group of ERC Environmental and Energy Services Co., Inc., hydrogeologist Timothy A. Lee. All well construction materials and supplies were from Martin Marietta Energy Systems approved batches. The batch origin of individual items is shown on the included Monitoring Well Materials Certification form.

\subsection{Technical Information}

\subsection{Decontamination Procedures}

The drilling rig, down hole tools, surface casing, stainless steel screen, stainless steel casing, centralizers, and stainless steel silt trap underwent the cleaning decontamination procedures outlined in the drilling specifications (Release Specific Technical Directions for Regulatory Compliance Monitoring Wells Phase 1, Oak Ridge National Laboratory, Oak Ridge, w.0. K-4147, April 1987, pgs. 2-4). A checklist of the cleaned materials is included with this data package.

\section{$2.2000109 \mathrm{Y}$}

WAG 17 encompasses approximately 23 acres in Bethel Valley, which is in the Valley and Ridge Physiographic Province of East Tennessee. WAG 17 is underlain by the Middle Ordovician Chickamauga Group consisting mainly of limestone and siltstone. The chickamauga Group consists of eight units, designated by letters A through H (Stockdale, 1951). WAG 17 is underlain by units E, F, $G$ and a portion of $H$. These units consist of thin bedded nodular limestone with clay and shale partings. Portions of units $H$ and $F$ consist of 
ENC / EDGE

Environmental

and Energ

Services Co.

calcareous siltstone alternating with beds of olive gray to maroon shale. The regional strike is $56^{\circ}$ northeast and has a moderate dip of $30^{\circ}$ to $40^{\circ}$ southeast.

\subsection{Bample collection}

No soil samples were collected during drilling.

A drill water sample was collected from the water pump on the drill rig on 12-7-89. Analytical results for the schramm Rotadrill drill water samples described above can be obtained from the Remedial Action Program data base at ORNL.

The Schramm Rotadrill compressed air was sampled with a cloth filter inserted between drill rods on 12-7-89. The sample was examined with an ultraviolet light for the presence of hydrocarbons. The filter showed no detectable hydrocarbons under ultraviolet light.

\subsection{Inotellation and Dovelopment}

\subsubsection{Instel1ation}

This was a type B well. A 22.0-inch diameter boring was augered from ground surface to 3.4 feet (auger refusal). A 15 1/4-inch diverter casing was installed from surface to 3.4 feet below ground surface and grouted in place. The boring was then extended past the refusal depth with a 14 1/2-inch air rotary tricone roller bit from 3.4 feet to 30.0 feet. A 10 3/4-inch diameter string of decontaminated steel surface casing was Installed from 0.0 feet to 30.0 feet, sealed with a 1.1-foot bentonite pellet layer from 28.9 feet to 30.0 feet, and tremie-grouted in place. The surface casing minimizes potential crose contamination between the regolith 
and bedrock water bearing zones. After the surface casing was installed, the air rotary method was used to drill an 8inch diameter boring to a total depth of 48.0 feet. A 4-inch diameter stainless steel screen with bottom cap was installed from 37.6 feet to 47.8 feet. A 4-inch diameter stainless steel casing was installed from the top of the screen at 37.6 feet and extended 2.0 feet above ground surface. A sandpack was then tremied into the annular space from 35.4 to 47.8 feet, with a 3.5-foot bentonite pellet seal poured into the annular space above the sandpack from 31.9 to 35.4 feet. The annular space from the top of the bentonite seal to the surface was tremie grouted with a cement/bentonite slurry. A detailed schematic of the well is included on the well installation/completion form.

\section{4 .2 We11 Development}

Well number 1201 was developed to remove drill cuttings, silt, and other fines. The monitoring well was developed using a Geoguard pump with an air compressor. All pumps were cleaned prior to use according to specified cleaning procedures (see Paragraph 2.1). The well was developed until a measured total of 315 gallons of water had been evacuated and the clarity of the discharge water was approved by the company representative. The Ilnal turbidity value measured at completion was 2.0 NTU's. A development form showing the exact method of development and other pertinent data is appanded.

$2 \cdot 4 \cdot 3$

Instalintion of Dedicated Monitoring Nell Pump

After the well was developed, a Geoguard Model No. 5614 dedicated monitoring well pump was installed on 4-2-90 at a depth of 46.8 below ground surface. These pumps are 
decontaminated at American Sigma and are sent prepackaged. A copy of the pump certification is kept on file at ORNL.

\subsection{Hydraulic Conduotivity Testing}

Well number 1201 was tested for the determination of hydraulic conductivity of the aquifer in the vicinity of the well screen. This was accomplished by instantaneously adding a known quantity of water to the monitoring well and measuring the recovery of the water level over time. The changing water levels were measured using a Druck Model DPI600 pressure transducer. The hydraulic conductivity value of $9.63 \times 10^{-6} \mathrm{~cm} / \mathrm{second}$ (shown as permeability on the hydraulic conductivity calculations printout attached) was calculated using the Bouwer and Rice method. A computer printout of the hydraulic conductivity calculations is included in this data package. 


\section{PRE-DRILLING CHECKLIST FOR MONITORING WELLS}

RRE-DRILUNG IASKS

1. EXCAVTION PERMIT OBTAINED

2. ALL EQUIPMENT HAS BEEN CLEANED BEFORE DRILUNG.

30. SCREEN AND CASING HAVE BEEN WASHED, STEAMED, RINSED WTH DE-IONIZED OR DISTILED WATER, RINSED WIT ISOPROPK ALCOHOL WRAPPEO MTH PROTECTVE COVERING AND STORED OFF THE GROUND.

36. PRE-PACKAGED SCREENS, CASING AND CENTRALIZERS MERE USED.

4. WORK AREA FOR SAMPLE EXAMINA TION COVERED WTH CLEAN POL TETHRENE.

5. CLEAN KNIVES, GOVES, SAMPLE JARS AND LABELS ON HAND.

6. POL YETHRENE COVER IN PLACE OVER HOLE.

7. ARR ROTARY COMPRESSED AR SAMPLED.
COMPLIANCE

DAIE

$\underline{11-30-89}$

$\underline{11-30-89}$

$N / A$

$12-07-89$

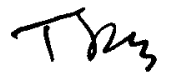

$11-30-89$

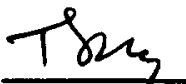

$11-30-89$

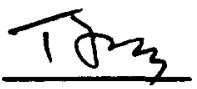

$11-30-89$

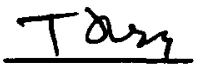

$12-07-89$

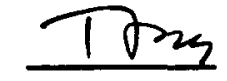

RESULIS: Showed no hydrocarbons under Ultra violet light.

ADDITIONAL NOTES/OBSERVATIONS.

observer sIGATURE DATE $\frac{\text { Jimoth Coy }}{\text { Timothy A. Lee }}$ 
ERC / EDGE

Environmental

and Energy

WELL No.1201

Services Co.

\section{DECONTAMINATION CHECKLIST \\ DRILLING EQUIPMENT}

\begin{tabular}{|c|c|c|c|c|c|}
\hline EQUIPMENT & SCRAPE & $\begin{array}{l}\text { STEAN } \\
\text { CLEAN }\end{array}$ & $\begin{array}{l}\text { STEAN } \\
\text { RINSE }\end{array}$ & $\begin{array}{c}\text { ISOPROPY } \\
\text { ALCOHOL } \\
\text { RINSE }\end{array}$ & $\begin{array}{c}\text { DEIONIZED } \\
\text { WAIER } \\
\text { RINSE } \\
\end{array}$ \\
\hline RIG & $x$ & $x$ & $x$ & $N / A$ & $N / A$ \\
\hline AUGERS & $x$ & $x$ & $x$ & $x$ & $x$ \\
\hline BITS & $x$ & $x$ & $x$ & $x$ & $x$ \\
\hline RODS & $x$ & $x$ & $x$ & $x$ & $x$ \\
\hline SAMPLERS & $x$ & $x$ & $x$ & $x$ & $x$ \\
\hline PIPES & $x$ & $x$ & $x$ & $x$ & $x$ \\
\hline WORK TOOLS & $x$ & $x$ & $x$ & $x$ & $x$ \\
\hline AUGER PINS & $x$ & $x$ & $x$ & $x$ & $x$ \\
\hline & & & & & \\
\hline & & & & & \\
\hline & & & & & \\
\hline & & & & & \\
\hline
\end{tabular}

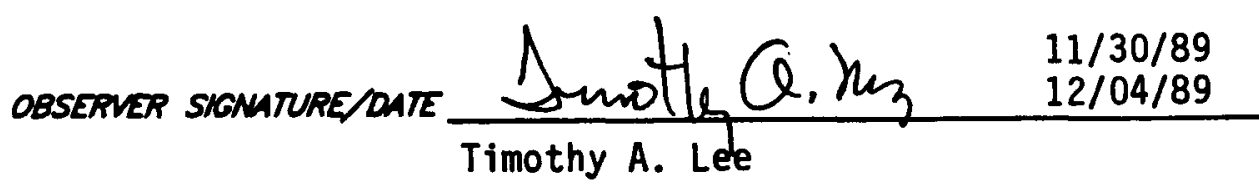




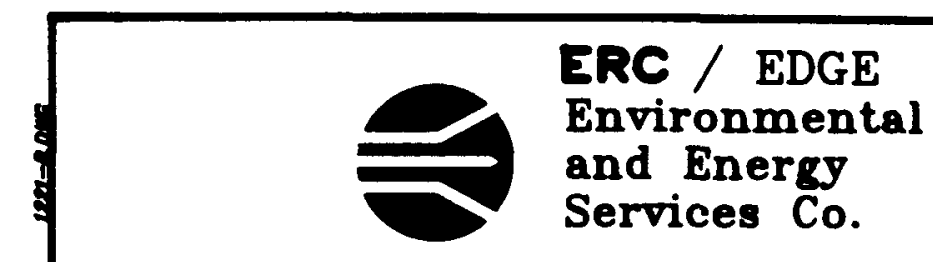

ORNL MONITORING WELL LOG

LOCA TON: WAG 17

DRILLER: George Akins

HELPER: James Shelton

ORIL: Schramm Rota drill

TPE DRILUNG: Auger. Air Rotary

No. SAMPLES TAKEN: None

CONTAINMENT TYPE: Plastic, Pan, Containment Box

THICKNESS OF SOL (REFUSAL DEPTH): 3.4

DEPTH DRILED IN ROOK: 44.6

TOTAL DEPTH OF WELL: 48.0

\begin{tabular}{|c|c|c|c|c|}
\hline \multicolumn{2}{|c|}{$\begin{array}{c}\text { OEPTH } \\
\text { (FEET) } \\
\text { FRON to }\end{array}$} & $\begin{array}{l}\text { SAMPLE } \\
\text { (NUMBER A } \\
\text { INTERVAL) }\end{array}$ & $\begin{array}{c}\text { PERCENT } \\
\text { RECOVERY } \\
\text { (SPUT SPOONS) }\end{array}$ & SOK/BEDROCK DESCRIPTION \\
\hline 0.0 & 1.0 & & Augered & Asphalt and gravel. \\
\hline \multirow[t]{3}{*}{1.0} & 3.4 & & Augered & Gravel and clay, dark yellowish orange, moist, \\
\hline & & & & dense, medium stiff. \\
\hline & 3.4 & & & Auger refusal \\
\hline 3.4 & 25.0 & & & **Limestone, hard. \\
\hline 25.0 & 27.0 & & & Limestone, hard. \\
\hline 27.0 & 27.2 & & & Limestone, shaley, soft. \\
\hline 27.2 & 30.0 & & & Limestone, hard. \\
\hline 30.0 & 43.3 & & & Limestone, hard. \\
\hline 43.3 & 43.7 & & & Limestone, shaley, soft. \\
\hline \multirow[t]{5}{*}{43.7} & 48.0 & & & Limestone, hard. \\
\hline & 48.0 & & & Total Depth \\
\hline & & & & **No detailed lithologic descriptions are \\
\hline & & & & available from $3.4^{\prime}$ to $48.0^{\prime}$ due to the \\
\hline & & & & use of contaiment box. \\
\hline & & & & \\
\hline & & & & \\
\hline & & & & \\
\hline & & & & \\
\hline & & & & \\
\hline
\end{tabular}




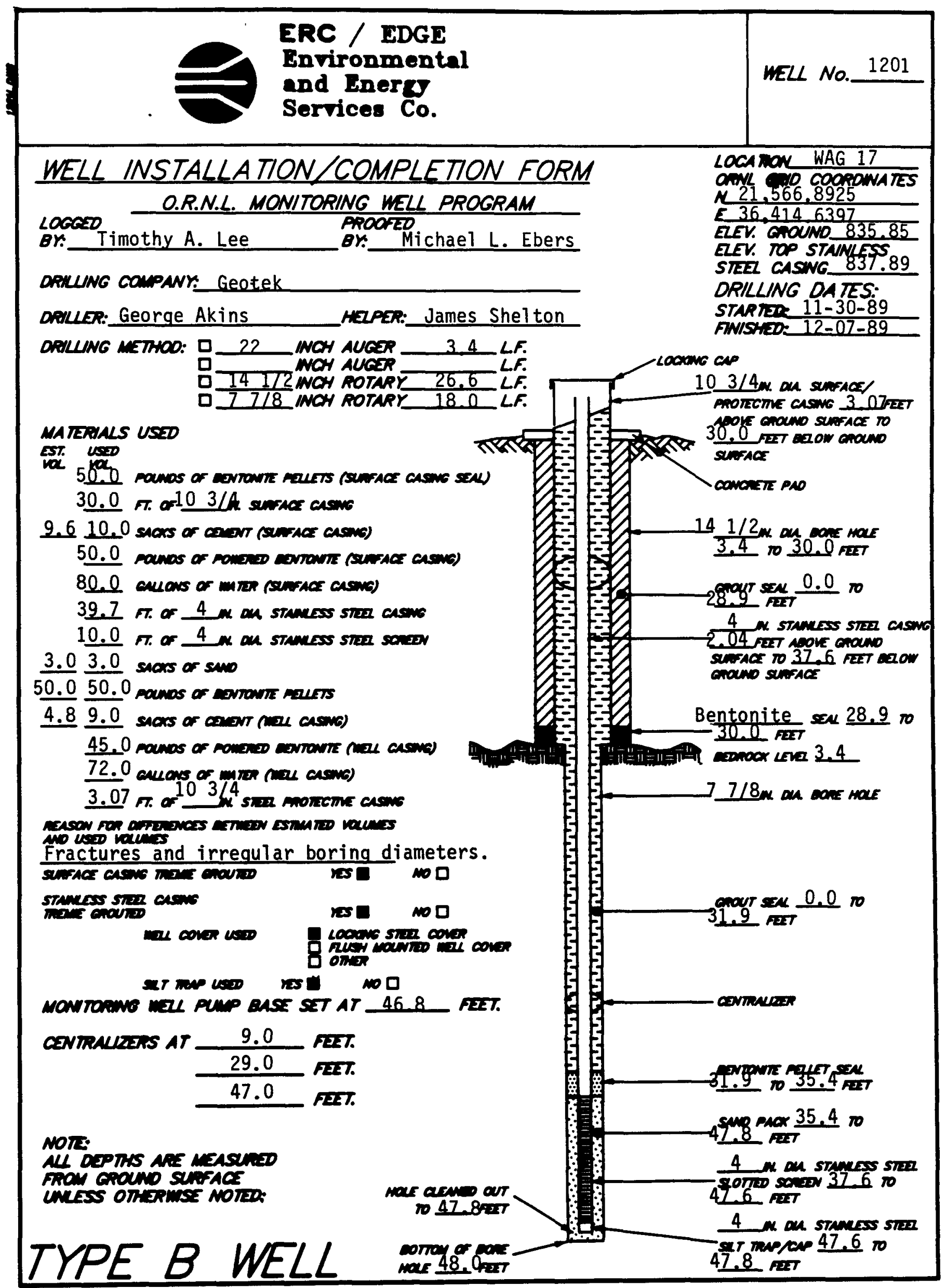

PACE 10 or 18 
ERC / EDGE

Environmental

WELL NO._1201

and Energy

Services Co.

DATE: $12-07-89$

\section{MONITORING MELL MATERIALS CERTIFICATION}

ITEM/NA TERIAL

DATE USPD BATCH NUMPER

SAND

BENTONITE

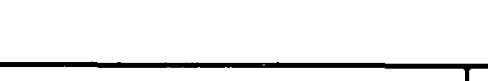

STAINLESS STEEL SCREEN

STAINLESS STEEL CASNG

STAINLESS STEEL CENTRALIZERS

STAINLESS STEER CAPS

MONITORNG MELL PUNA

Geovt

(PREPACKACED

(PREPACKaEzo

(PREPACKACED

(PREPACKAGED

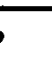

WELL COVERS

SUAFACE CASWG

12-05-89

MMES Stores

COMMENTS:

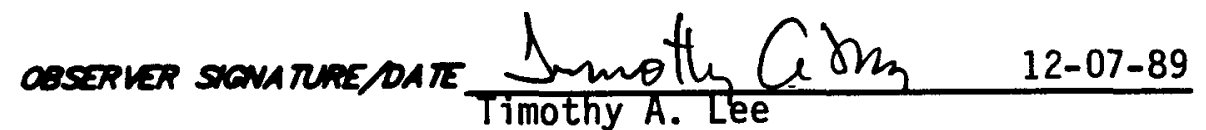

D.Chonlassute 4-02-90

D. Charles LytTe

PACE 11 of 18 


\section{POST-MELL COMPLETION CHECKLIST}

\section{POST-WELL COMPLETION TASKS}

1. WU SCRAPED FRON AUGERS SMMPLERS ANO NLL OTHER EOUIPIENT.

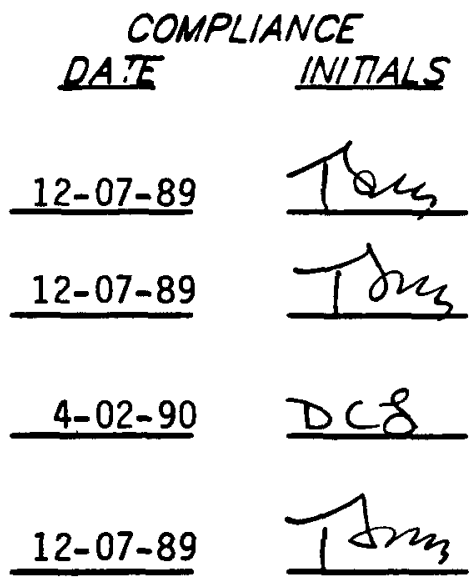

4 OANULNG STE PAOPERLY CLEANED UP ATIER

complemon of WrI INSTALATION.

2. ALL WUO FRON ANG ANO EQUMUENT SCRAPINGS AND CUTTNES DISPOSED OF W ACCORDANCE WIT THE SPECITCA IION PPOVOED.

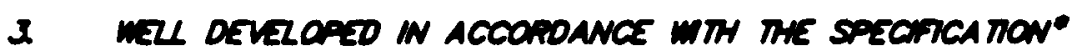
PROVOED ANO OETAKS OF ME DEVZZ OPWENT ACTUT RECOROSD.

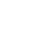


ERC / EDGE

Environmental

and Energy

WELL NO. 1201

Services Co.

\section{MONITORING WELL \\ DEVELOPMENT FORM}

DEVELOPMENT DETAILS

METHOD OF SEYELOMENT: Surging and Pumping

OEVEOPMENT $3 / 28 / 90$

TME:

DEVELOPMENT

ENOING DATE: $\quad 4 / 02 / 90$

DEVELOPMENT

OBSERVED BY: D. Charles Lytle

ONE WEL VOUUM: 36.7 GNLONS

TOTAL GALONS PUMPED:-315 TOTA MEL VOLUMES PUMPED: 8.6

INITAL PH: 7.7 GNAL PH: 7.6

INITAL CONOUCTIUTY (US): 748 FNAL CONOUCTUTH (US): 737

OESCRIPTON OF INTIAL TURBIOITY: MUddY

DESCRIPTON OF ANAL TURBIOITY Clear

FNAL MEASURED RURBIOITY 2.0 NTU'S

WEL APPROVED BY. R. C. Williams MMES

OOOR

OF NATR: None

WATER GROUND SURFACE

DISCHARGED

sTORW SEMERS

To:

a DPLMS

D TANK TRUCK

D STORAGE TANKS

口 ORHER

INITAL PRE-DEVEZOPNENT

WATER OEPTH: 4.5 feet from ground surface.

DEVELOPMENT OBSERVA TONS

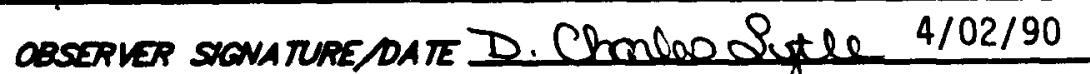

D. Charles Lytle 


\begin{tabular}{|c|c|c|c|c|c|c|c|c|c|}
\hline 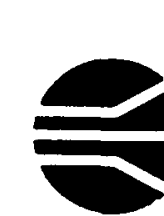 & $\begin{array}{l}\text { ER } \\
\text { Env } \\
\text { and } \\
\text { Ser }\end{array}$ & $\begin{array}{l}\text { ED } \\
\text { onme } \\
\text { Energ } \\
\text { ces C }\end{array}$ & & & & & & & $\begin{array}{l}\text { 10. } \frac{1201}{\text { ON:WAG } 17} \\
3 / 28 / 90 \\
\end{array}$ \\
\hline & $M O$ & TORI & $G \quad F E L L$ & $D E V E$ & LOF & PMEN & $P R$ & FRES & \\
\hline & & & & & & & WeZL $k$ & $M E=$ & 7 GALLONS \\
\hline DATE & TME & $\begin{array}{l}\text { Gulows } \\
\text { PUMPED }\end{array}$ & 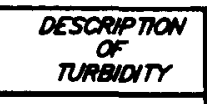 & 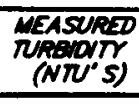 & $\overline{\rho H}$ & $\begin{array}{c}\text { Conouc- } \\
\text { MnYr } \\
\text { (us) }\end{array}$ & 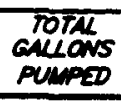 & $\begin{array}{l}\text { Ment } \\
\text { vacumes } \\
\text { Peumed }\end{array}$ & COMMENTS \\
\hline $3-39-90$ & 1400 & 228 & Muddy & -- & 7.7 & 748 & 228 & 6.2 & \\
\hline $3-30-90$ & 0830 & 18 & $\begin{array}{l}\text { Slightly } \\
\text { cloudy }\end{array}$ & -- & 7.8 & 738 & 246 & 7.0 & \\
\hline $3-30-90$ & 1300 & 58 & $\begin{array}{l}\text { Slightly } \\
\text { cloudy }\end{array}$ & -- & 7.6 & 791 & 304 & 8.3 & \\
\hline $4-02-90$ & 0900 & 11 & Clear & 2.0 & 7.6 & 737 & 315 & 8.6 & \\
\hline & & & & & & & & & \\
\hline & & & & & & & & & \\
\hline & & & & & & & & & \\
\hline & & & & & & & & & \\
\hline & & & & & & & & & \\
\hline & & & & & & & & & \\
\hline & & & & & & & & & \\
\hline & & & & & & & & & \\
\hline & & & & & & & & & \\
\hline & & & & & & & & & \\
\hline & & & & & & & & & \\
\hline & & & & & & & & & \\
\hline & & & & & & & & & \\
\hline $\begin{array}{l}\text { RESULTS } \\
\text { OF DEVE }\end{array}$ & $\begin{array}{l}\text { TEND } \\
\text { DMENT }\end{array}$ & & Clear & 2.0 & 7.6 & 737 & 315 & 8.6 & \\
\hline
\end{tabular}

COMMENTS Nice recharger and producer. Water cleared, passed and moved to another hole. 


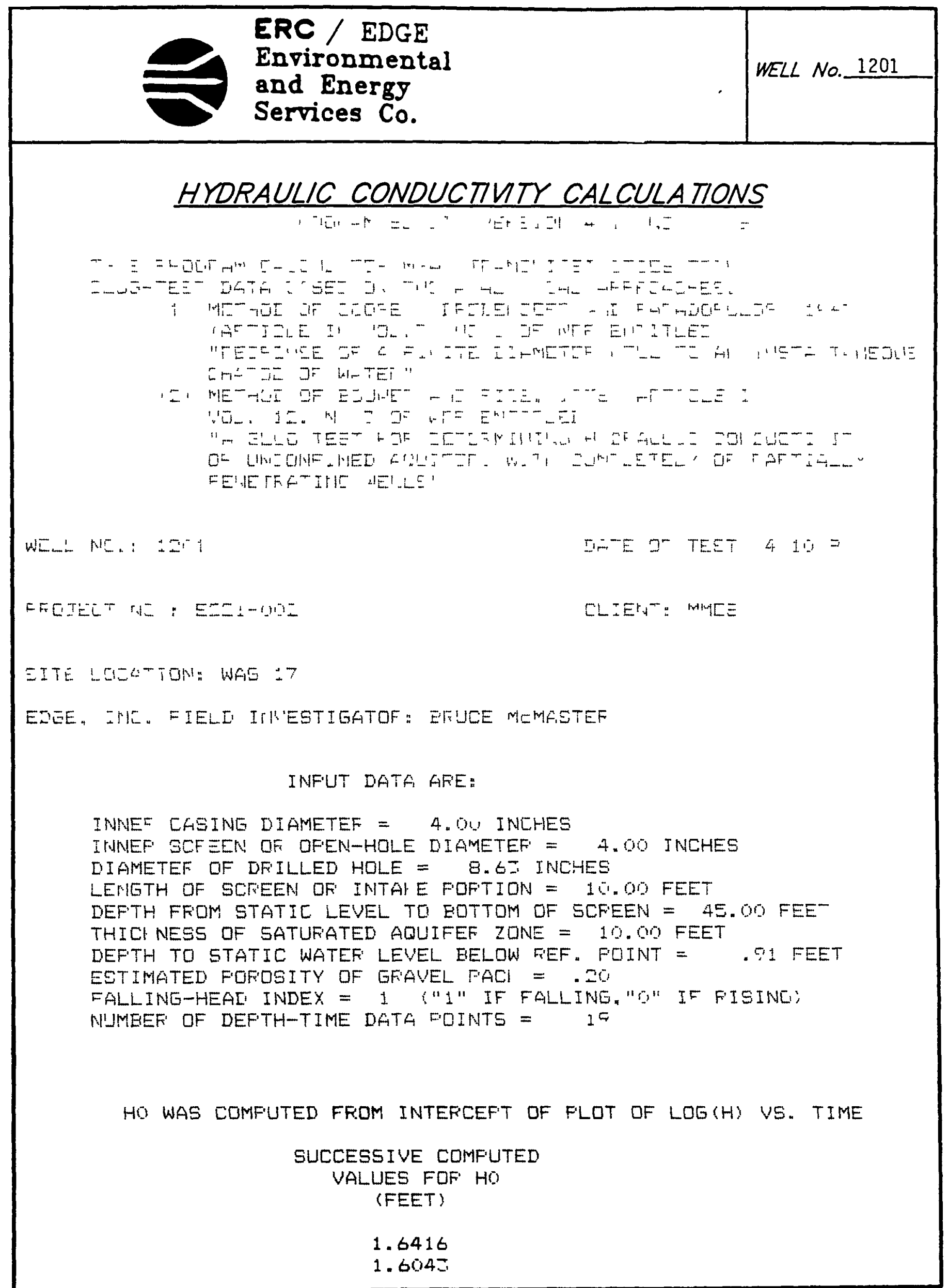




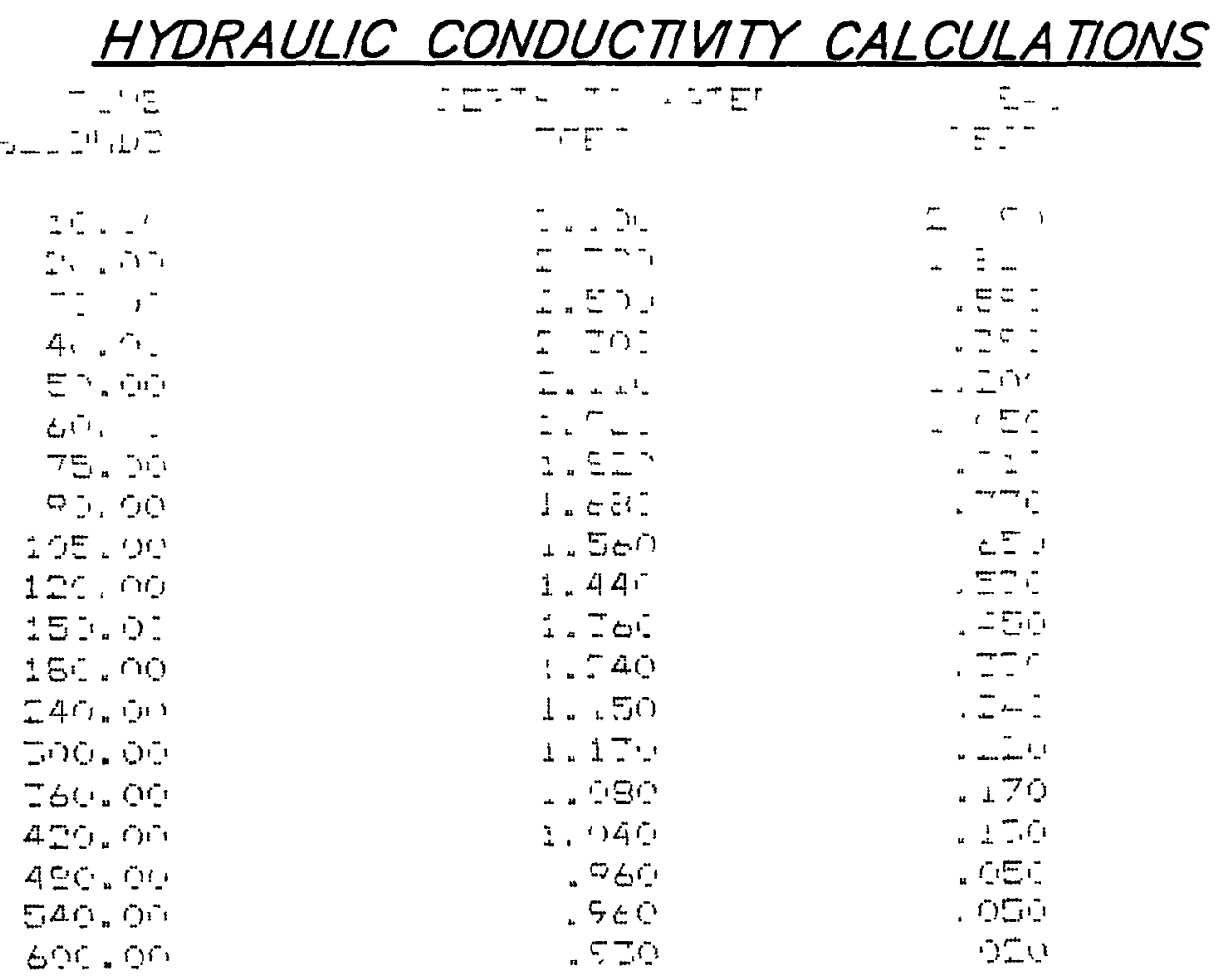

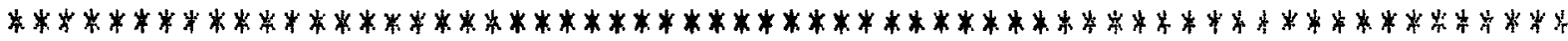

METHOD OF BOUWEF' AND F'ICE

COMFUTED FESLLTS USING DIAMETEF OF DFILLED HOLE:

FEFMEAEIL:TY $= \pm .16 E-15$ FT/SECONDS =9.6ZE-0.4 CH,SES

TFANSMISSIVITY = =.16E-04 FT**ISECONDS

COMFUTED FESULTS USINE DIAMETEF DF CAEING AND SCFEEN:

$$
\begin{aligned}
& \text { FEFMEAEILITY }=\text { =.81E-05 FT/SECONDS = } \\
& \text { TFANSMISSIVITY }=7.81 E-04 \text { FT**I/SECONDS }
\end{aligned}
$$




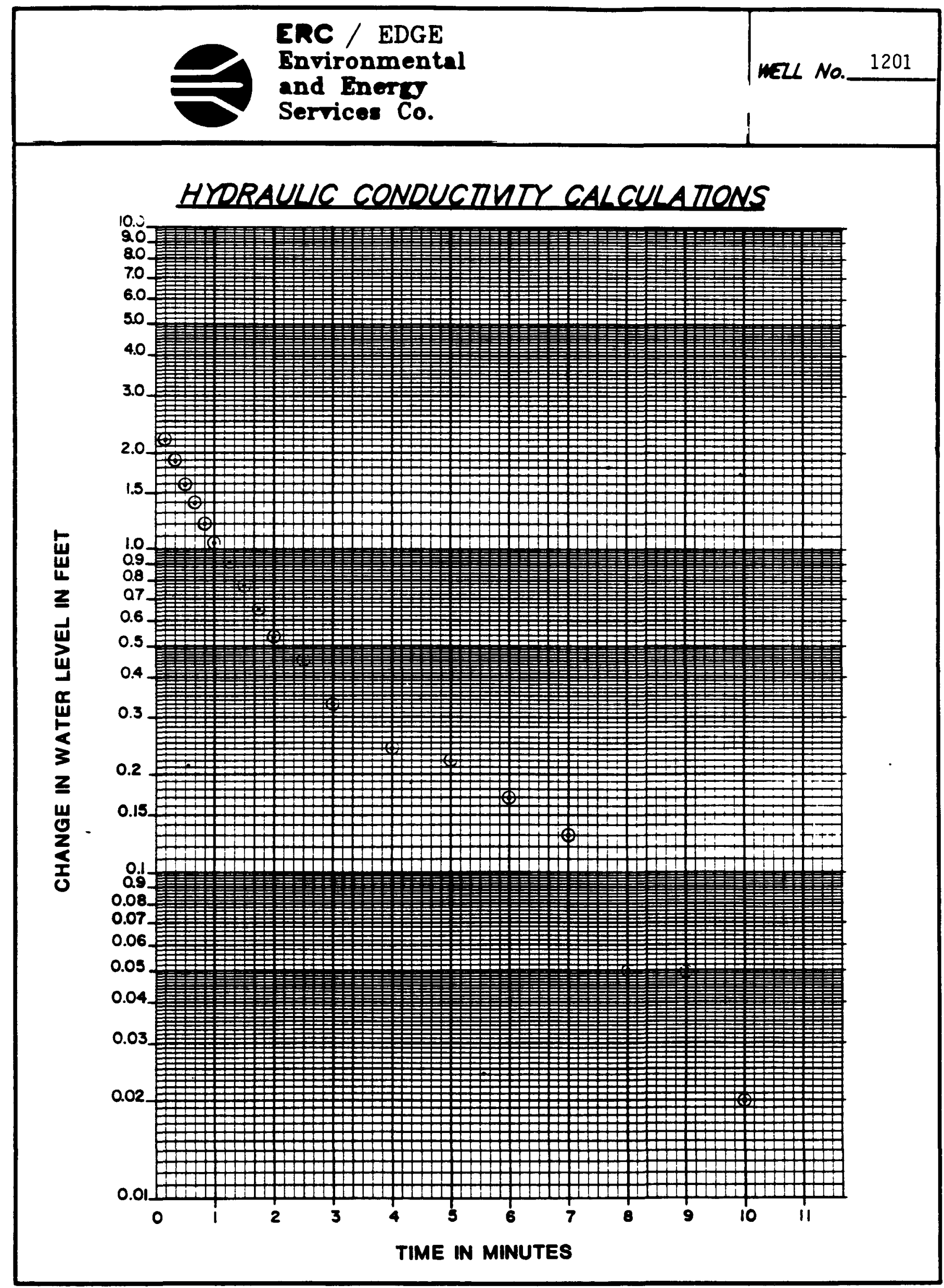




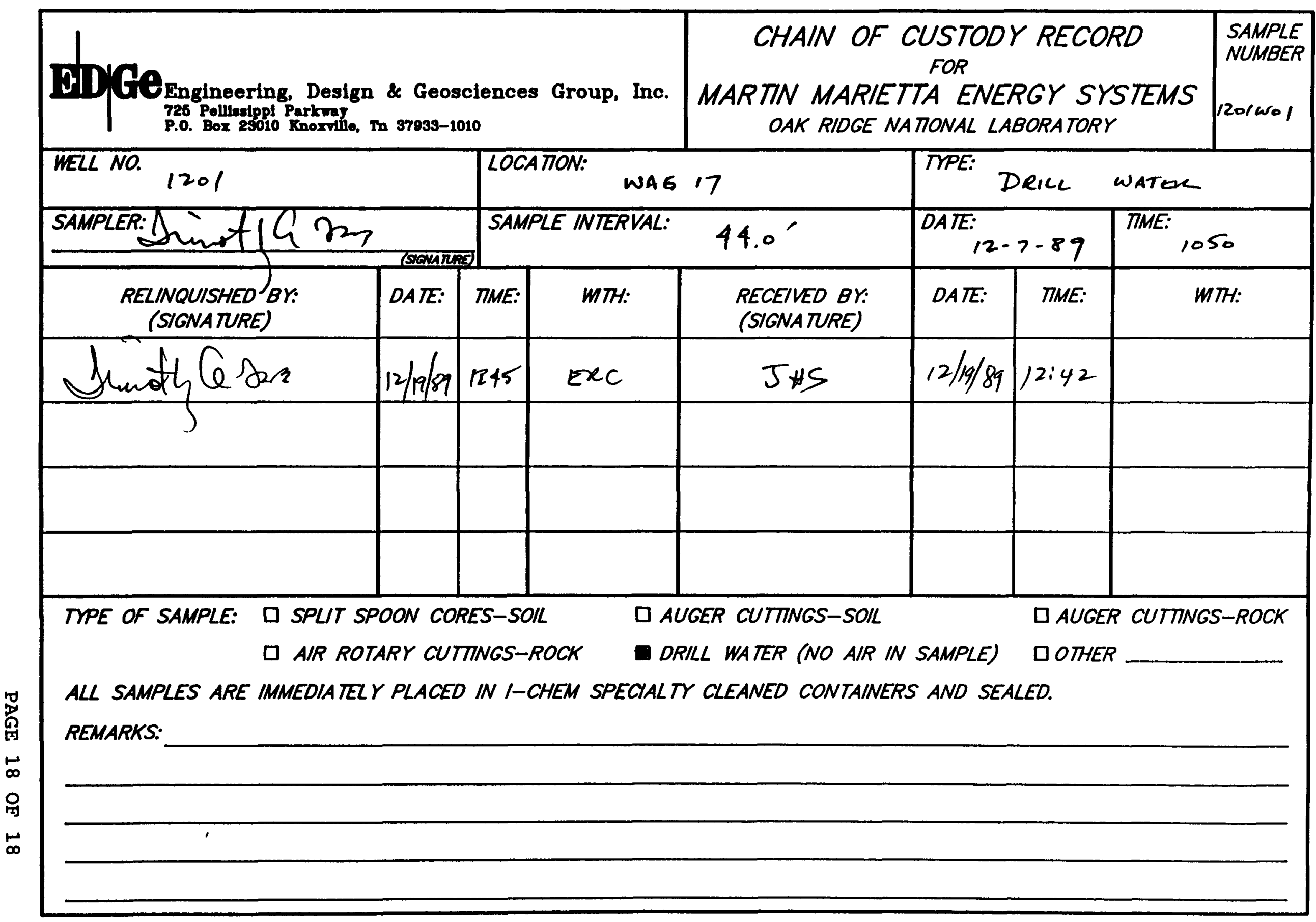


1.0 General Information

1.1 Nell Loontion

Monitoring well number 1202 is located in WAG 17. It is in the western portion of WAG 17, approximately 100' south of the west portal. The location is shown on ORNL drawing number C3E20004 A075. Survey coordinates for this well at $N$ $21,581.5347$, E $36,414.7669$ (X-10 grid) or latitude $35^{\circ}-56^{\prime}-$ $01.71^{\prime \prime}$ and longitude $84^{\circ}-18^{\prime}-03.54^{\prime \prime}$. Coordinate data were provided by Martin Marietta Energy systems. The method used for conversion from $x-10$ grid to Tennessee-Lambert state Plane Coordinates came from the publication "Tennessee Valley Authority Data Services Branch and Mapping Services Branch, Oak Ridge, Tennessee, DOE Plant Control, November 6, 1985, Field Book: EsS-3115, pp. 1-20." The latitude and longitude were calculated by Adams Craft Herz Walker Engineering, Inc., using methods from the U.S. Coast and Geodetic survey Publication 62-4, "State Plane Coordinates by Automatic Data Processing."

\subsection{Drilling Informition}

Well number 1202 was drilled by Geotek Engineering Company. An Ingersoll Rand $T-4$ and a Schramm Rotadrill rig was used to dr111 this boring for monitor well installation under the operation of Larry Ledbetter/George Akins with the assistance of Fred Dixon/Steve Kirk/James Shelton. Drilling commenced on 11-8-89 and was Iinished on 12-11-89. Paragraph 2.4.1 includes a detailed discussion of the well installation and a well schematic is included on the well installation/completion form. A synopsis of the arilling activity follows. This information was typed directly from field notes and was edited only when necessary for clarification. 
11-8-89: The Ingersoll Rand T-4 rig was moved to the well site and set up on plastic. The boring was augered from ground level to 0.8 feet with 8 inch auger and split spoon samples were taken from 0.8 feet to 3.6 feet (refusal). The boring was then augered from ground level to 3.5 feet to refusal with a 22 inch auger and 3.5 feet of decontaminated diverter casing was set and grouted into place.

11-16-89: A Schramm rig was set up on plastic and deepened the boring from 3.5 feet to 10.0 feet with a 14 inch air rotary tricone bit using the diverter and containment box. $103 / 4^{\prime \prime}$ decontaminated steel casing was set at 10.0 feet. The rig was moved from location.

11-17-89: The surface casing was grouted with 2.0 sacks cement.

11-29-90: The rig was moved to location. The boring was deepened from 10.0 feet to 50.0 feet using a $77 / 8$ inch air rotary tricone bit. A large volume of vater was encounterad from 14.0 feet to 15.0 feet. Therefore it was decided to drill the offset well and plug this well back to 25.0 feet. The rig was moved from the location.

12-7-89: The boring was plugged back to 22.9 feet with 5.0 sacks cement.

12-11-89: Set 20.0 feet of stainless steel screen and casing with a sand pack and bentonite seal. 
EnC / EDGE

Environmental

12-12-89: The casing was grouted into place with 1.5 sacks of cement.

This well was logged by the EDGe Group of ERC Environmental and

Energy Services Co., Inc., hydrogeologist Timothy A. Lee. All well construction materials and supplies were from Martin Marietta Energy Systems approved batches. The batch origin of individual items is shown on the included Monitoring Well Materials Certifica-tion form.

\subsection{Technionl Information}

\subsection{Decontamination Procodures}

The drilling rig, down hole tools, surface casing, stainless steel screen, stainless steel casing, centralizers, and stainless steel silt trap underwent the cleaning decontamination procedures outlined in the drilling specifications (Release Specific Technical Directions for Regulatory Compliance Monitoring Wells Phase 1, Oak Ridge National Laboratory, Oak Ridge, W.0. K-4147, April 1987, pgs. 2-4). A checklist of thie cleaned materials is included with this data package.

\section{$2.2600109 y$}

WAG 17 encompasses approximately 23 acres in Bethel Valley, whlch 18 in the Valley and Ridge Physiographic Province of East Tenneseee. WAG 17 is underlain by the Middle Ordovician Chickamauga Group consieting mainly of limestone and siltstone. The Chickamauga Group consists of eight units, designated by letters $A$ through $\boldsymbol{H}$ (Stockdale, 1951) . WAG 17 is underlain by units E, F, $G$ and a portion of $H$. These units consist of thin bedded nodular limestone with clay and 
shale partings. Portions of units $H$ and $F$ consist of calcareous siltstone alternating with beds of olive gray to maroon shale. The regional strike is $56^{\circ}$ northeast and has a moderate dip of $30^{\circ}$ to $40^{\circ}$ southeast.

\section{3 sample collection}

One soil sample was collected during drilling, placed in an I-CHEM specialty cleaned glass container, sealed and submitted to Sample Receiving, Analytical Chemistry Division, Bldg. 4500s, ORNL. A chain of custody form for this soil sample is included with this data package. Soil sample 1202501 was collected in the split spoon interval from 3.1 ' to $3.5^{\prime}$ on $11-8-89$.

A drill water sample was collected from the water pump on the drill rig on 11-29-89. Analytical results for the schramm Rotadrill drill water sample described above can be obtained from the Remedial Action Program data base at ORNL.

A bulk density soil sample was collected from the split spoon sample interval from $3.1^{\prime}$ to $3.5^{\prime}$. The sample was measured and weighed, and a bulk density of 2.0 grams/ $\mathrm{cm}^{3}$ was calculated.

The Schramm Rotadrill compressed air was sampled with a cloth f11ter inserted between dri11 rods on 11-29-89. The sample was examined with an ultraviolet light for the presence of hydrocarbons. The filter showed no evidence of hydrocarbons. 
2.4 Installation and Development

2.4.1 Installation

This was a type B well. A 22.0-inch diameter boring was augered from ground surface to 3.5 feet. A 15 1/4-inch diverter casing was installed from surface to 3.5 feet below ground surface and grouted in place. A 6-inch diameter boring was augered from 0.0 feet to 3.6 feet (auger refusal) . The boring was then extended past the refusal depth with a 14 $1 / 2$ - inch air rotary tricone roller bit from 3.6 feet to 10.0 feet. A 10 3/4-inch diameter string of decontaminated steel surface casing was installed from 0.0 feet to 10.0 feet, sealed with a 2.7-foot bentonite pellet layer from 7.3 feet to 10.0 feet, and tremie-grouted in place. The surface casing minimizes potential cross contamination between the regolith and bedrock water bearing zones. After the surface casing was installed, the air rotary method was used to drill an 8-inch diameter boring to a total depth of 50.0 feet. The well has plugged back to 20.3 feet. A 2-inch diameter stainless steel screen with threaded bottom cap was installed from 10.1 feet to 20.3 feet. A 2-inch diameter stainless steel casing was installed from the top of the screen at 10.1 feet and extended 2.10 feet above ground surface. A sandpack was then tremied into the annular space from 7.8 to 20.3 feet, with a 1.8-foot bentonite pellet seal poured into the annular epace above the sandpack from 6.0 to 7.8 feet. The annular space from the top of the bentonite seal to the surface was tremie-grouted with a cement/bentonite slurry. A detailed schematic of the well is included on the well installation/completion form. 
ENe / EDGE

Environmental

and Enero

Services Co.

Well number 1202 was developed to remove drill cuttings, silt, and other fines. The monitoring was developed using a Geoguard pump with an air compressor. All pumps were cleaned prior to use according to specified cleaning procedures (see Paragraph 2.1). The well was developed until a measured total of 302 gallons of water had been evacuated and the clarity of the discharge water was approved by the company representa-tive. The final turbidity value measured at completion was $>100$ NTU'g. A development form showing the exact method of development and other pertinent data is appended.

2.4.3 Installation of Dedicated Monitoring vell Pump

After the well was developed, a Geoguard Model No. 5614 dedicated monitoring well pump was installed on 3-30-90 at a depth of 18.8 feet below ground surface. These pumps are decontaminated at American sigma and are sent prepackaged. A copy of the pump certification is kept on file at ORNL.

\subsection{EYdraulio conductivity Festing}

Well number 1202 was tested for the determination of hydraulic conductivity of the aquifer in the vicinity of the well screen. This was accomplished by instantaneously adding a known quantity of water to the monitoring well and measuring the recovery of the water level over time. The changing water levels were measured using a Druck Model DPI600 pressure transducer. The hydraulic conductivity (shown as permeability on the hydraulic conductivity calculations 
printout attached) value of $1.13 \times 10^{-3} \mathrm{~cm} / \mathrm{second}$ was calculated using the Bouwer and Rice method. A computer printout of the hydraulic conductivity calculations is included in this data package. 


\section{PRE-DRILLING CHECKLIST FOR MONITORING WELLS}

RRE-ORILUNG TASKS

1. EXCAVION PERMIT OBTAINED

2. ALL EQUIPMENT HAS BEEN CLEANED BEFORE DRILING.

30. SCREEN AND CASING HAVE BEEN WASHED, STEAMED, RINSED WTH DE-IONIZED OR DISTLLED WATER, RINSED WTH ISOPROPV ALCOHOL, WRAPPED WTH PROTECTVE COVERING AND STORED OFF THE GROUND.

36. PRE-PACKAGED SCREENS, CASING AND CENTRALIERS WERE USED.

4. WORK AREA FOR SAMPLE EXAMINATION COVERED WTH CLEAN POL VETHRENE.

5. CLEAN KNIVES, GOVES, SAMPLE JARS AND LABEZS ON HAND.

6. POLYTHRENE COVER IN PLACE OVER HOLE.

7. AIR ROTARY COMPRESSED AR SAMPLED.

\begin{tabular}{|c|c|}
\hline \multicolumn{2}{|c|}{ COMPLIANCE } \\
\hline $\begin{array}{c}\text { DAIE } \\
11 / 07 / 89\end{array}$ & $\frac{\text { NIMALS }}{\text { MLE }}$ \\
\hline $11 / 07 / 89$ & ME \\
\hline$N / A$ & $N / A$ \\
\hline
\end{tabular}

$12 / 11 / 89$

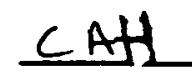

$11 / 07 / 89$

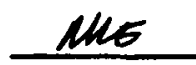

$11 / 07 / 89$

Ne

$11 / 07 / 89$ Me $\underline{11 / 16 / 89} \mathrm{CAH}$ RESULIS. Sample showed no hydrocarbons under ultra violet light.

ADOIMONAL NOTES/OBSERVA MONS:

OBSERVER SIGNATURE/DATE $C$. Coll Pl Nodrg 12/11/89

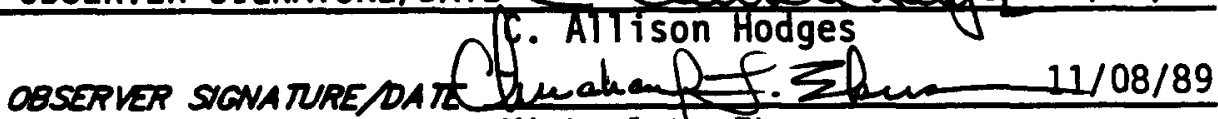
Michael 4 . Ebers 


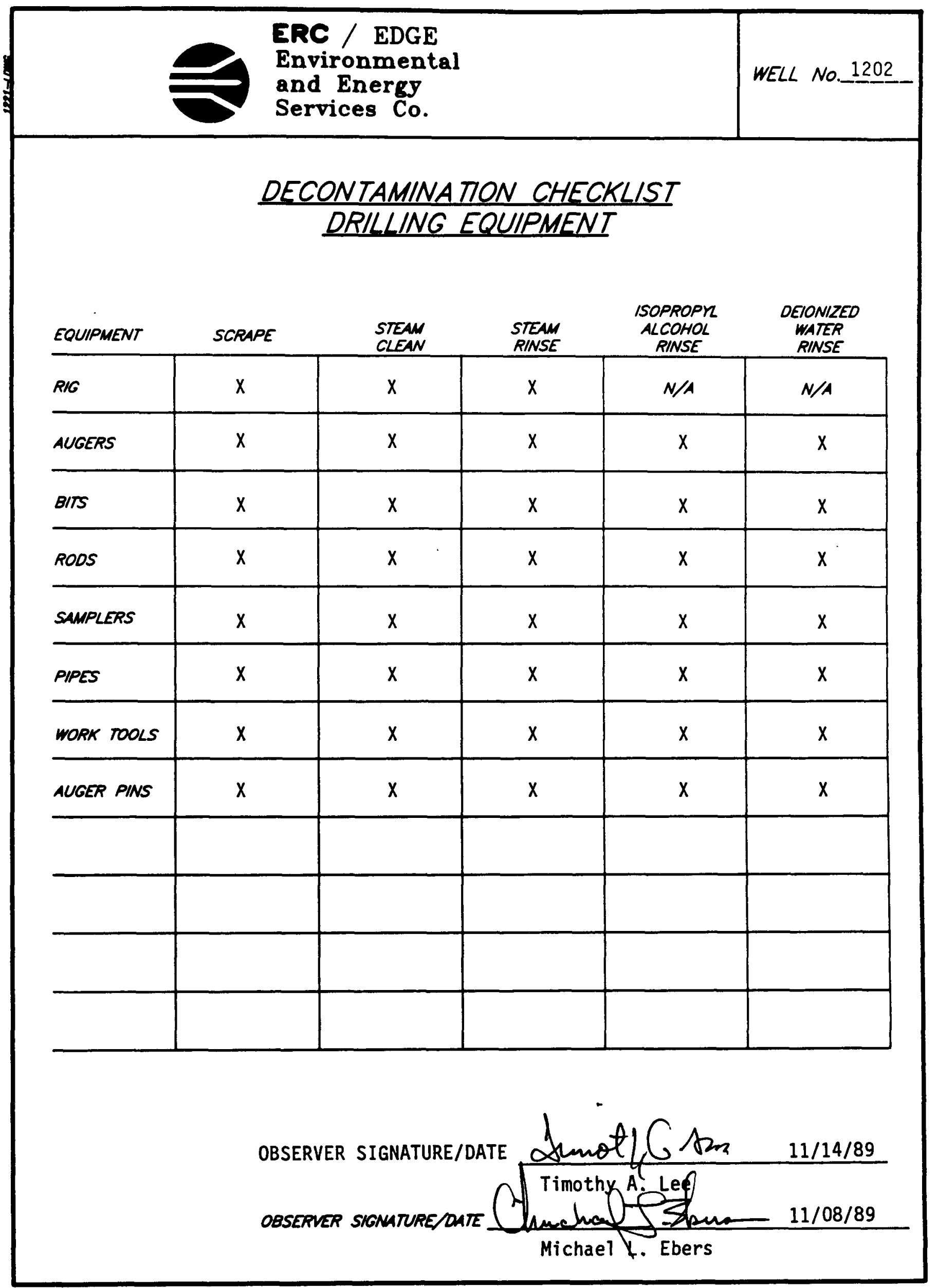

PAGE 9 OF 20. 


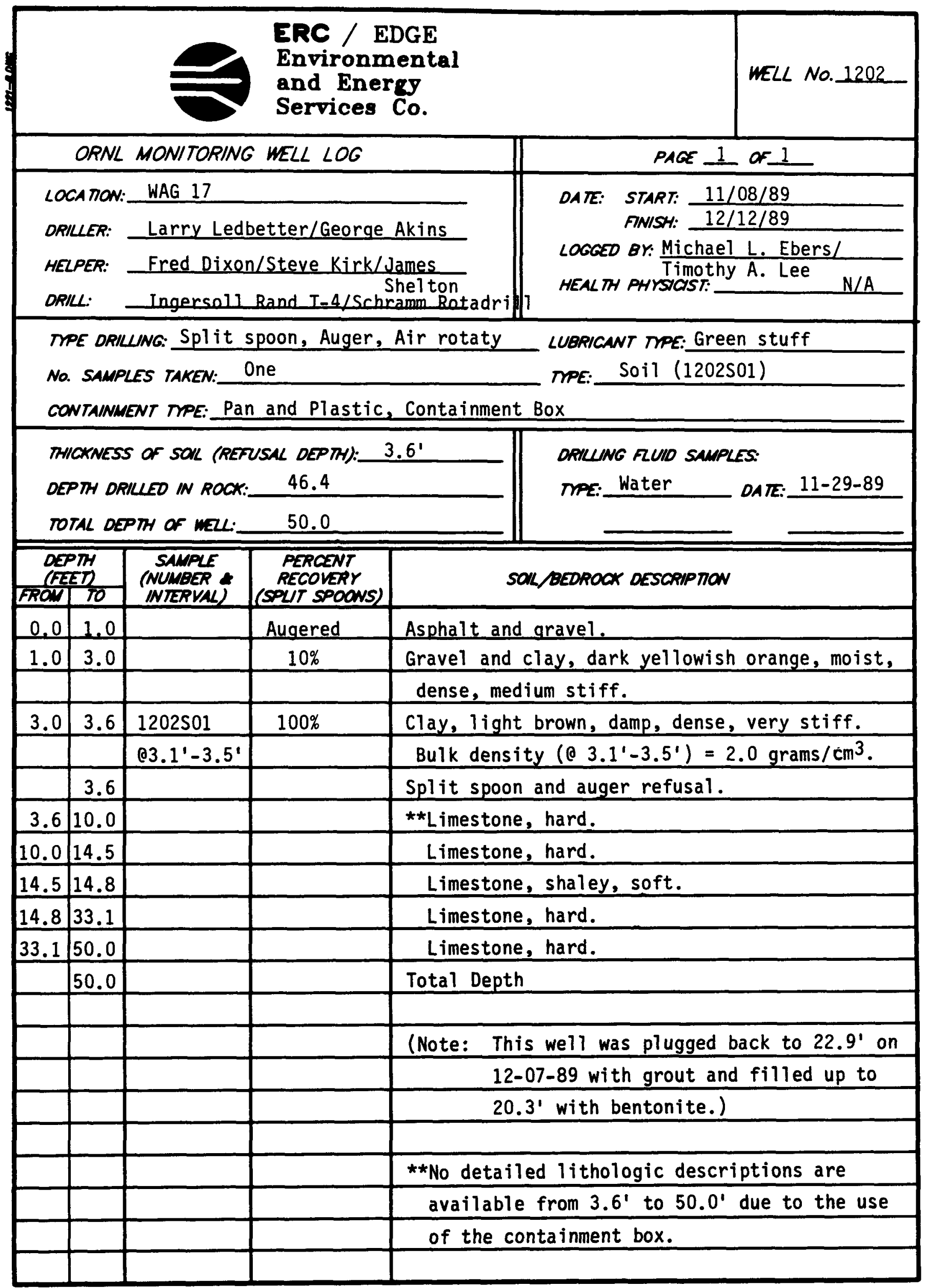




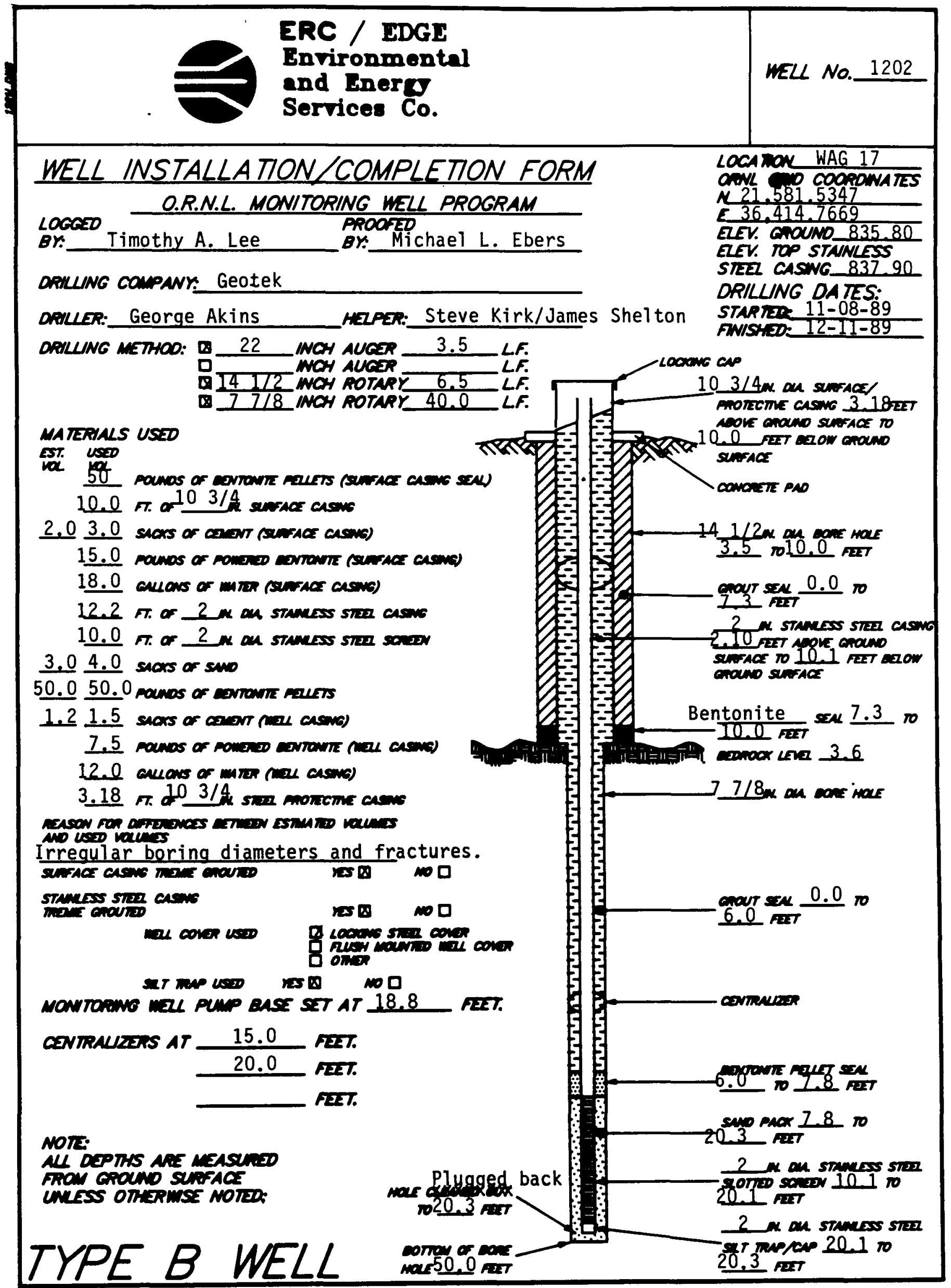

PACE 11 or 20 


\section{MONITORING MELL MATERIALS CERTIFICATION}

\begin{tabular}{|c|c|c|c|}
\hline \multicolumn{2}{|l|}{ ITEN/MA TERIAL } & DAIE USED & BATCH NUMBER \\
\hline SANO & & $12-11-89$ & 1 \\
\hline \multirow{2}{*}{ BENTONITE } & Pellets & $12-11-89$ & 1 \\
\hline & Powder & $12-11-89$ & 3 \\
\hline STAINLESS STEEL SCREEN & $\left(\begin{array}{ll}\text { (PAJPACXaED } & \text { rES } \\
\text { NO }\end{array}\right)$ & $12-11-89$ & 2 \\
\hline STAMLESS STEZZ CASING & $\left(\begin{array}{ll}\text { PREPACKACED } & \text { MES } \\
\text { nOS }\end{array}\right.$ & $12-11-89$ & 2 \\
\hline STAINLESS STEEL CENTRALIZERS & (PREPACXAGED O $\left.\begin{array}{l}\text { YES } \\
\text { NO }\end{array}\right)$ & $12-11-89$ & 2 \\
\hline STANEESS STEEL CAPS & 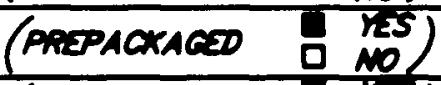 & $12-11-89$ & 2 \\
\hline Mowroping mele Penup & (AREPACKACED D NO) & $3-30-90$ & 5 \\
\hline \multirow{2}{*}{ GROUT } & \multirow{2}{*}{$\begin{array}{l}\text { Surface } \\
\text { SS Casing }\end{array}$} & $12-11-89$ & 3 \\
\hline & & $12-11-89$ & 3 \\
\hline \multicolumn{2}{|l|}{ Mell cOVERS } & $N / A$ & $N / A$ \\
\hline \multicolumn{2}{|l|}{ SUAFACE CASWNO } & $11-16-89$ & 3 \\
\hline
\end{tabular}

COMMENTS:

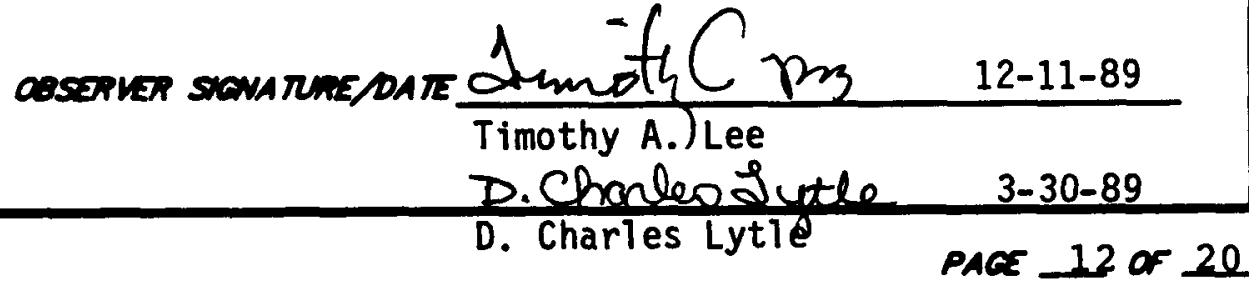




\section{POST-MELL COMPLETION \\ CHECKLIST}

\section{POST-WELL COMPLERON TASKS}

COMPLIANCE

\section{DA.TE INITIALS}

1. WO SCRAPCD FRON AUGSRS SAMPLERS ANO NU

$12-11-89$

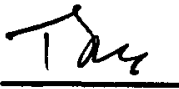
OTHER EQUIPMENT:

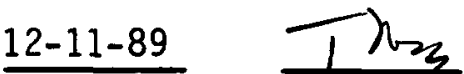

2. NIL WUD FRON RTG ANO EQUMNENT SCRAPWGS ANO CUTINOS OSPOOSED OF N ACCORDANCE WTH THE SPECARCA HON PROWOED.

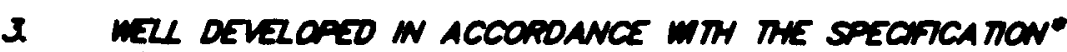
PROMOED ANO DETAKS OF THE OEVEZOPWENT ACTUTY RECOAOED.

4 DRULNG SITE PROPERLY CLEANED UP AFIER COMPLENON OF MIL INSTALATION.

$3-30-90$

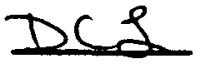

$12-11-89$

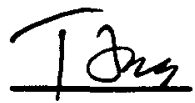

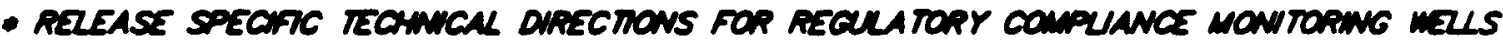

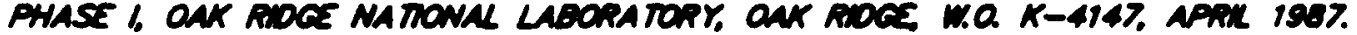

coserver scovarnespate yumotly Qtm 12-11-89

Dicharles dufte

$3-30-90$

D. Charles Lytle 
ERC / EDGE

Environmental

and Energy

Services Co.

\section{MONITORING WELL \\ DEVELOPMENT FORM}

DEVELOPMENT DETAILS

NETHOD OF

DEVELOPMENT: Surging and Pumping

DEVELOPMENT

BEGAN DATE: $3 / 28 / 90$

TME:

DEVELOPMENT: $3 / 30 / 90$
ENDING DATE:

OEVELOPNENT
OBSERVED BY: D. Charles Lytle

ONE WEL VOUUME: 7.4 GalloNs

TOTAL GALLONS PUMPED: 302 TOTA WEL VOLUMES PUMPED: 41.0

INITAL PH: 7.9 FNAL PH: 7.6

INITAL CONOUCTUTY (US): 546 TNAL CONOUCTUTH (US): 599

OESCPIPTION OF INITAL TURBIOIT: Cloudy

OESCRIPTION OF FNAL TURBIOITY Slightly Cloudy

FINAL MEASURED TURBIOIT: Greater than 100 NTU's.

WELL APPROVED Br: R. C. Williams MMES

OOOR None

WATER GOROUND SUAFACE

OISCHARGED I STORN SEWERS

TO:

a arens

D TANK TRUCK

D STORAGE TANKS

D OTHER

WITAL PRE-DEVZOPNENT

WATER DEPTH:

5.2 feet from ground surface.

DEVELOPMENT OBSERVA TONS

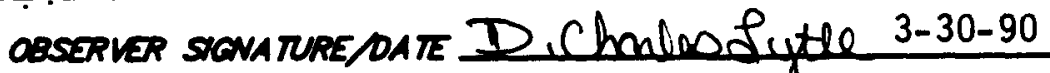

D. Charles Lytle 
ERC / EDGE

Environmental

and Energy

Services Co.

wEZL NO. 1202

LOCA TON: WAG 17

DATE: $3 / 28 / 90$

\section{MONITORING WELL DEVELOPMENT PROGRESS}

\begin{tabular}{|c|c|c|c|c|c|c|c|c|c|}
\hline \multicolumn{10}{|c|}{ ONE WELL VOLUME $=7.4$ GALLONS } \\
\hline DATE & TME & $\begin{array}{l}\text { Gulans } \\
\text { peuped }\end{array}$ & 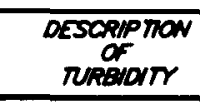 & 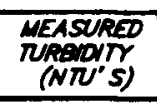 & $\rho H$ & $\begin{array}{c}\text { conouc- } \\
\text { Mur } \\
(4 S)\end{array}$ & 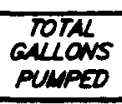 & 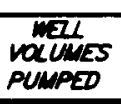 & COMMENTS \\
\hline $3-29-90$ & 1400 & 262 & Cloudy & -- & 7.9 & 546 & 262 & 35.4 & \\
\hline $3-30-90$ & 0830 & 40 & $\begin{array}{l}\text { Slightly } \\
\text { cloudy }\end{array}$ & $>100$ & 7.6 & 599 & 302 & 41.0 & \\
\hline & & & & & & & & & \\
\hline & & & & & & & & & \\
\hline & & & & & & & & & \\
\hline & & & & & & & & & \\
\hline & & & & & & & & & \\
\hline & & & & & & & & & \\
\hline & & & & & & & & & \\
\hline & & & & & & & & & \\
\hline & & & & & & & & & \\
\hline & & & & & & & & & \\
\hline & & & & & & & & & \\
\hline & & & & & & & & & \\
\hline & & & & & & & & & \\
\hline & & & & & & & & & \\
\hline & & & & & & & & & \\
\hline $\begin{array}{l}\text { RESULTS } \\
\text { of DEVEI }\end{array}$ & $\begin{array}{l}\text { ENO } \\
\text { PMENT }\end{array}$ & & $\begin{array}{l}\text { Slightly } \\
\text { cloudy }\end{array}$ & $>100$ & 7.6 & 599 & 302 & 41.0 & \\
\hline
\end{tabular}

COMMENTS Fast recharger and nice producer. Had to pass, on account of the well volumes. Water remains slightly cloudy. Passed and moved to another hole.

*Greater than 100 NTU's. 


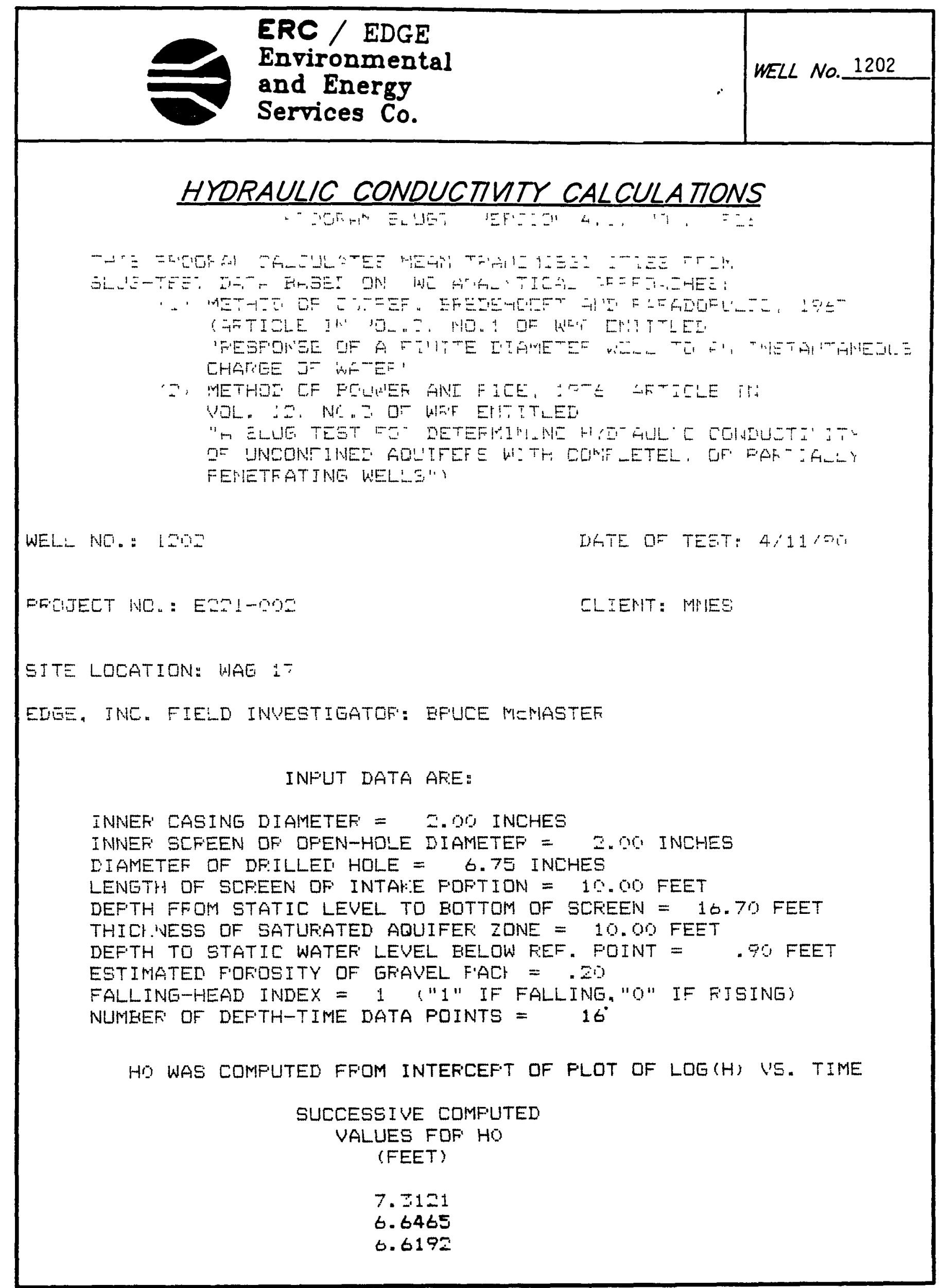




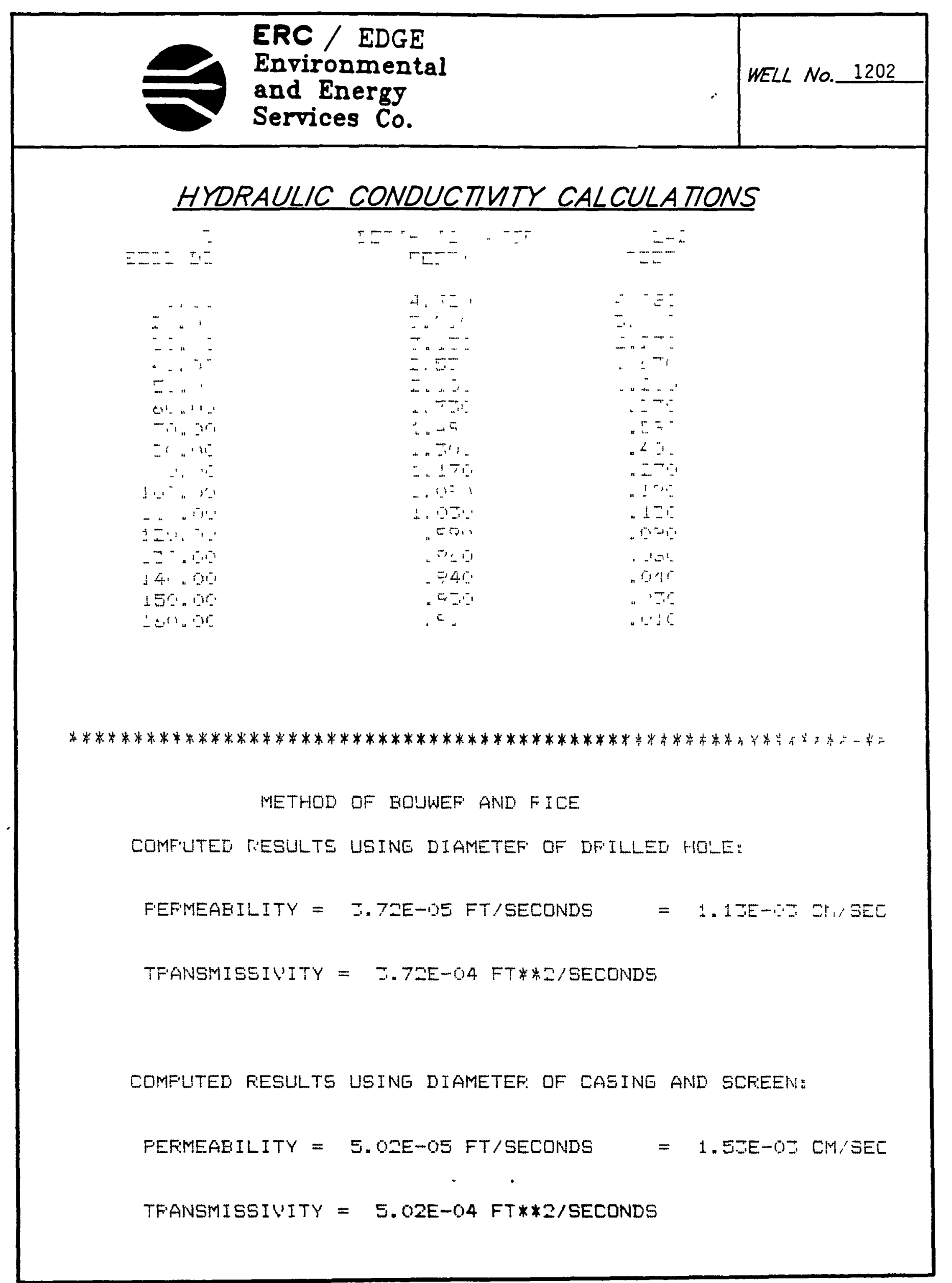

PAGE 17 OF 20 


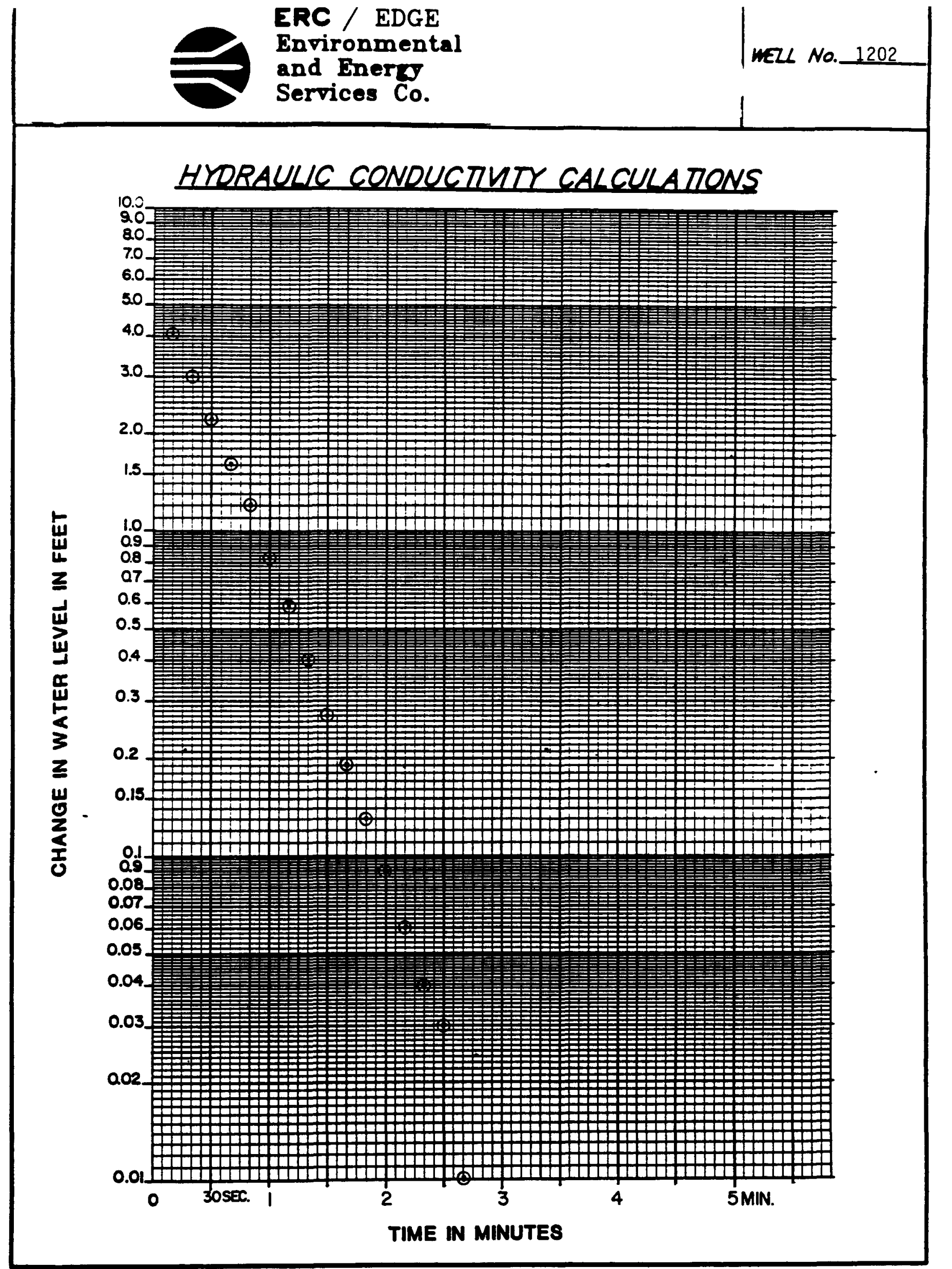

PACE 18 or 20 


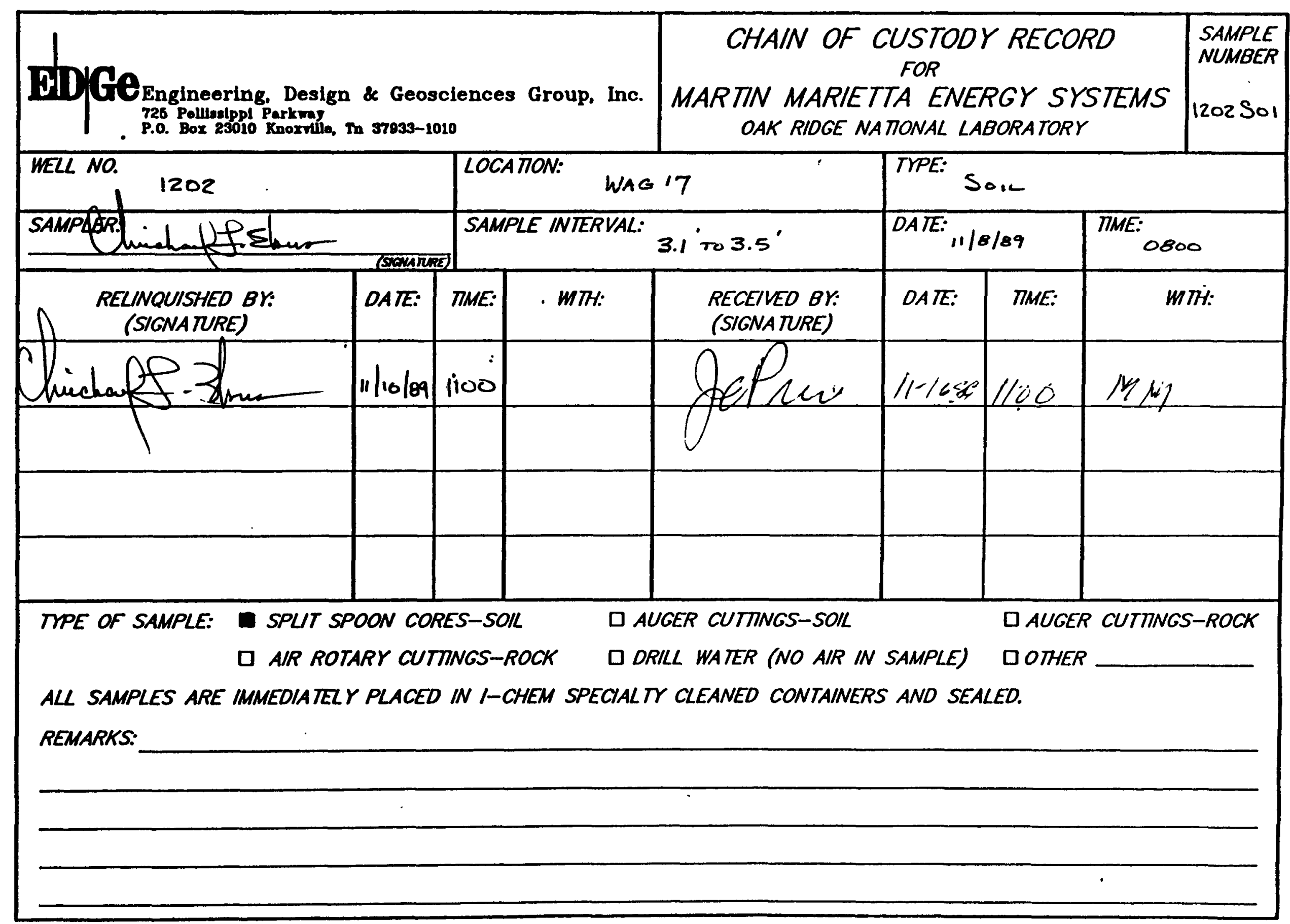




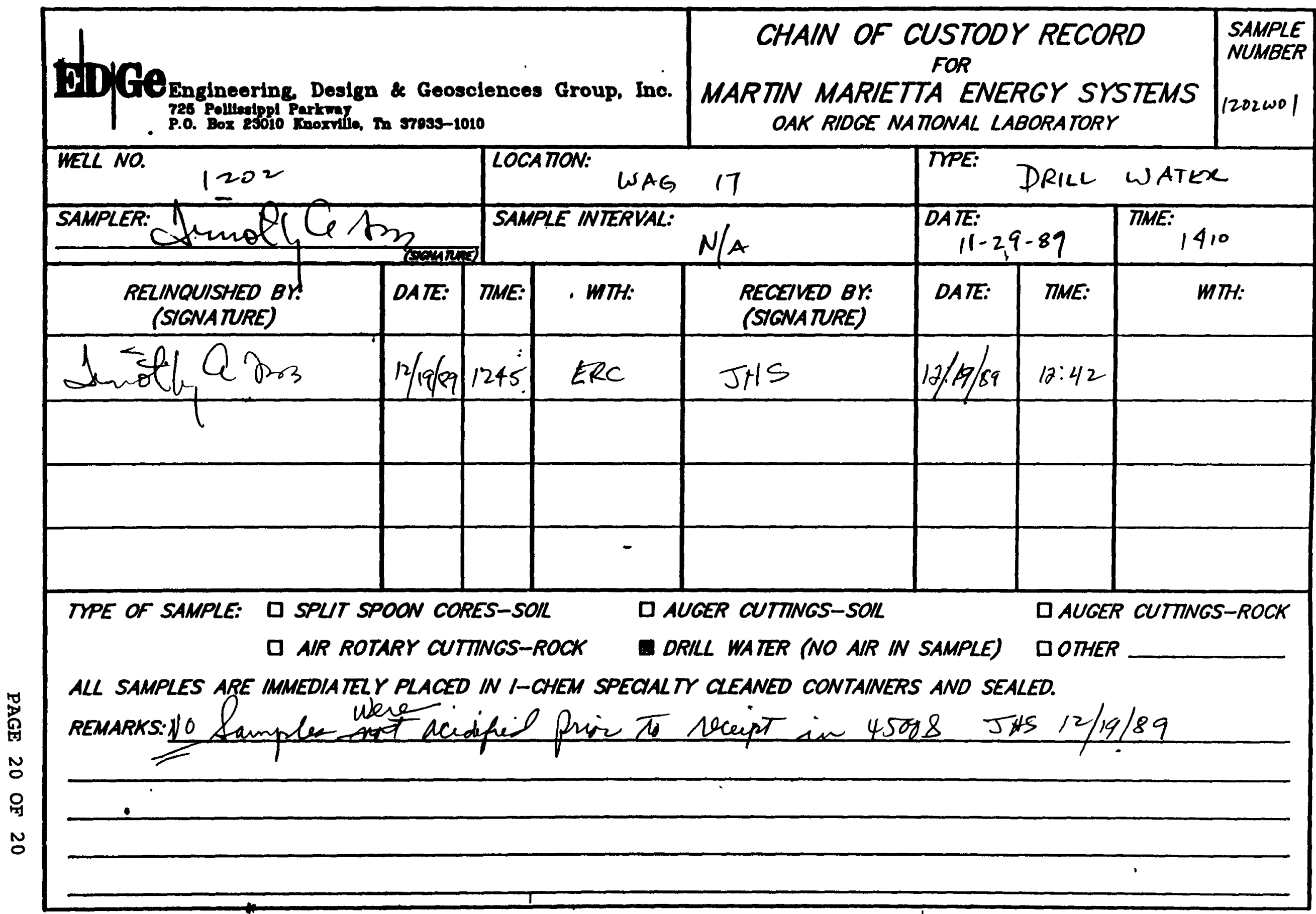


1.0 General Information

1.1 Nell Location

Monitoring well number 1203 is located in WAG 17. It is located approximately 150 feet due west of Building 7001 . The location is shown on ORNL drawing number C3E20004A075. Survey coordinates for this well at $N 21,916.3887$, E $36,272.9661$ ( $X-10$ grid) or latitude $35^{\circ}-56^{\prime}-03.68^{\prime \prime}$ and longitude $84^{\circ}-18^{\prime}-07.24^{\prime \prime}$. Coordinate data were provided by Martin Marietta Energy Systems. The method used for conversion from $x-10$ grid to Tennessee-Lambert state Plane coordinates came from the publication "Tennessee valley Authority Data Services Branch and Mapping Services Branch, Oak Ridge, Tennessee, DOE Plant Control, November 6, 1985, Field Book: ESS-3115, pp. 1-20." The latitude and longitude were calculated by Adams Craft Herz Walker Engineering, Inc., using methods from the U.S. Coast and Geodetic survey Publication 62-4, "State Plane Coordinates by Automatic Data Processing."

\subsection{Drilling Information}

Well number 1203 was drilled by Geotek Engineering Company. A Schramm Rotadrill rig was used to drill this boring for monitor well installation under the operation of George Akins with the assistance of James Shelton. Drilling commenced on 1-2-90 and was finished on 1-4-90. Paragraph 2.4.1 includes a detalled discussion of the well installation and a well schematic is included on the well installation/completion form. A synopsis of the drilling activity follows. This information was typed directly from field notes and was edited only when necessary for clarification. 
1-2-90: The rig was mobilized to location and set up on plastic sheeting. Split spoon samples were taken from surface to refusal at 5.2 feet. A 6 inch auger was used to deepen the boring to 10.7 feet. A 14 inch auger was used to 4.0 feet and $103 / 4$ inch decontanimated steel diverter casing was set at 4.0 feet. The rig was moved from the location.

1-3-90: The diverter casing was grouted into place with 2 sacks of cement.

1-4-90: The rig was moved to location. The boring was deepened to 18.0 feet using a $77 / 8$ inch air rotary tricone bit into the containment box. stainless steel 2 inch screen and casing was set with sand pack and bentonite seal.

1-5-90: The stainless steel casing was grouted into place using 1 sack cement.

This well was logged by the EDGe Group of ERC Environmental and Energy Services Co., Inc., hydrogeologist Timothy A. Lee. All well construction materials and supplies were from Martin Marietta Energy Systems approved batches. The batch origin of individual items is shown on the included Monitoring Well Materials Certification form.

2.0 Technioal Information

\subsection{Decontanination Procedures}

The drilling rig, down hole tools, surface casing, stainless steel screen, stainless steel casing, centralizers, and 
stainless steel silt trap underwent the cleaning decontamination procedures outlined in the drilling specifications (Release Specific Technical Directions for Regulatory Compliance Monitoring Wells Phase 1, Oak Ridge National Laboratory, Oak Ridge, w.O. K-4147, April 1987, pgs. 2-4). A checklist of the cleaned materials is included with this data package.

\subsection{9}

WAG 17 encompasses approximately 23 acres in Bethel valley, which is in the Valley and Ridge Physiographic Province of East Tennessee. WAG 17 is underlain by the Middle ordovician Chickamauga Group consisting mainly of limestone and siltstone. The Chickamauga Group consists of eight units, designated by letters A through $\mathrm{H}$ (Stockdale, 1951). WAG 17 is underlain by units E, F, G and a portion of H. These units consist of thin bedded nodular limestone with clay and shale partings. Portions of units $H$ and $F$ consist of calcareous siltstone alternating with beds of olive gray to maroon shale. The regional strike is $56^{\circ}$ northeast and has a moderate dip of $30^{\circ}$ to $40^{\circ}$ southeast.

\section{3 sanple colloction}

One soll sample was collected during drilling, placed in an I-CHEY speclalty cleaned glass container, sealed and submitted to Sample Receiving, Analytical Chemistry Division, Bldg. 4500s, ORNL. A chain of custody form for this sample is included with this data package. Soil sample 1203501 was collected in the split spoon interval from 3.2 to 3.5 feet on 1-2-90.

A drill water sample was collected from the water pump on the drill rig on 1-4-90. Analytical results for the schramm 
Sne / BDGS

Environmental

and Enercs

Services Co.

Rotadrill drill water samples described above can be obtained from the Remedial Action Program data base at ORNL. A bulk density soil sample was collected from the split spoon sample interval from 3.2 to 3.5 feet. The sample was measured and weighed, and a bulk density of $2.22 \mathrm{gms} / \mathrm{cm}^{3}$ was calculated.

The Schramm Rotadrill compressed air was sampled with a cloth filter inserted between drill rods on 1-4-90. The sample was examined with an ultraviolet light for the presence of hydrocarbons. The filter showed no evidence of hydrocarbons.

\subsection{Installation and Dovelopnent}

\section{4 .1 Insta11ation}

This was a type D well. A 6-inch diameter boring was split spooned/augered from ground surface to auger refusal (5.2 feet). The air rotary method was required to complete the boring to the epecified total well depth. Therefore, a 14.0inch diameter boring was augered from ground surface to 4.0feet and a 10 3/4-inch diverter casing was installed and grouted. An 8-inch diameter boring was then drilled with an air rotary tricone roller bit from 5.2 to 18.0 feet. A 2inch diameter stainless steel screen with threaded bottom cap was Installed Irom 7.6 to 17.8 feet. A 2-inch diameter stainlese steel casing was installed above the screen at 7.6 feet and extended 2.02 feet above ground surface. A sandpack was then tremied into the annular space from 5.6 to 17.8 feet, with a 1.6-foot bentonite pellet seal poured into the annular space above the eandpack from 4.0 to 5.6 feet. The annular space from the top of the bentonite seal to the surface was tramie-grouted with a cement/bentonite slurry. $A$ detail of the well is included on the well installation/completion form. 


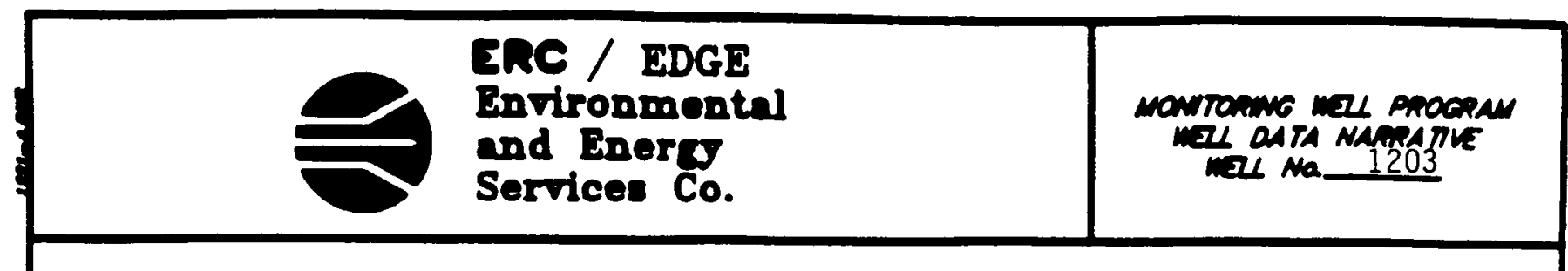

2.4.2 Well Development

Well number 1203 was developed to remove drill cuttings, silt, and other fines. The monitoring was developed using a Geoguard pump with an air compressor. All pumps were cleaned prior to use according to specified cleaning procedures (see Paragraph 2.1). The well was developed until a measured total of 174 gallons of water had been evacuated and the clarity of the discharge water was approved by the company representa-tive. The final turbidity value measured at completion was 2.0 NTU's. A development form showing the exact method of development and other pertinent data is appended.

\subsubsection{Installation of Dedionted Monitoring Well Pump}

After the well was developed, a Geoguard Model No. 5614 dedicated monitoring well pump was installed on 4-3-90 at a depth of 16.5 feet below ground surface. These pumps are decontaminated at American sigma and are sent prepackaged. A copy of the pump certification is kept on file at ORNL.

\subsection{Hydraule Conductivity Testing}

Well number 1203 was tested for the determination of hydraulic conductivity of the aquifer in the vicinity of the well screen. This was accomplished by instantaneously adding a known quantity of water to the monitoring well and measuring the recovery of the water level over time. The changing water levels were measured using a Druck Model DPI600 pressure transducer. The hydraulic conductivity value of 
$1.97 \times 10^{-4} \mathrm{~cm} / \mathrm{second}$ (shown as permeability on the hydraulic conductivity calculations printout attached) was calculated using the Bouwer and Rice method. A computer printout of the hydraulic conductivity calculations is included in this data package. 


\section{PRE-DRILLING CHECKLIST FOR MONITORING WELLS}

\section{RRE-DRILLNG TASKS}

1. EXCAVTION PERMIT OBTAINED

2. ALL EQUIPMENT HAS BEEN CLEANED BEFORE DRILUNG.

30. SCREEN AND CASING HAVE BEEN WASHED, STEAMED, RINSED WTH DE-IONIZED OR DISTLLED WA TER, RINSED WTH ISOPROPN ALCOHOL WRAPPED WTH PROTECTVE COVERING AND STORED OFF THE GROUND.

36. PRE-PACKAGED SCREENS, CASING AND CENTRALIZERS MERE USED.

4. WORK AREA FOR SAMPLE EXAMINATON COVERED WTH CLEAN POL YETHIENE.

5. CLEAN KNIVES, QLOVES, SAMPLE JARS AND LABELS ON HAND.

6. POLYTHIENE COVER IN PLACE OVER HOLE.

7. AR ROTARY COMPRESSED AR SAMPLED.
COMPLIANCE

$\frac{\frac{\text { DAIE }}{1-02-90}}{\frac{1-02-90}{\text { N/A }}} \frac{\frac{\text { NIIALS }}{\text { Thy }}}{\text { The }}$

$1-04-90$

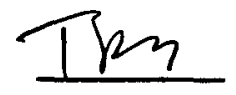

$1-04-90$

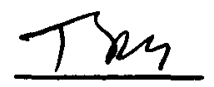

$1-04-90$

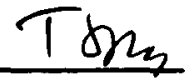

$1-04-90$

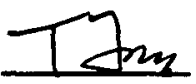

$1-04-90$

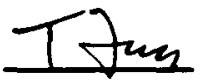

RESUL IS. No detectable hydrocarbons were detected under ultra violet light.

ADOITONAL NOTES/OBSERVATIONS:

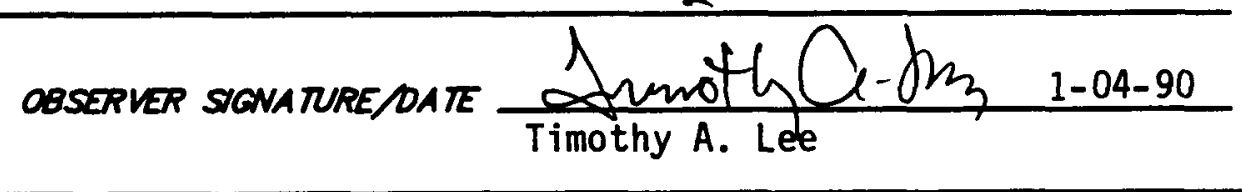

PAGE 7 or 20 
DECONTAMINATION CHECKLIST DRILLING EQUIPMENT

\begin{tabular}{|c|c|c|c|c|c|}
\hline EOUIPMENT & SCPAPE & $\begin{array}{l}\text { STEN } \\
\text { CLEW }\end{array}$ & $\begin{array}{l}\text { STEW } \\
\text { RusE }\end{array}$ & $\begin{array}{c}\text { sopioph } \\
\text { Kcoval } \\
\text { Ruvse }\end{array}$ & $\begin{array}{c}\text { DEEONIZZED } \\
\text { WAIER } \\
\text { RINSE }\end{array}$ \\
\hline RNG & $x$ & $x$ & $x$ & $N / A$ & $N / A$ \\
\hline ALCERS & $x$ & $x$ & $x$ & $x$ & $x$ \\
\hline Brrs & $x$ & $x$ & $x$ & $x$ & $x$ \\
\hline ROOS & $x$ & $x$ & $x$ & $x$ & $x$ \\
\hline SAMPLERS & $x$ & $x$ & $x$ & $x$ & $x$ \\
\hline PIPES & $x$ & $x$ & $x$ & $x$ & $x$ \\
\hline WORK TOOLS & $x$ & $x$ & $x$ & $x$ & $x$ \\
\hline AUGER PINS & $x$ & $x$ & $x$ & $x$ & $x$ \\
\hline & & & & & \\
\hline & & & & & \\
\hline & & & & & \\
\hline & & & & & \\
\hline
\end{tabular}

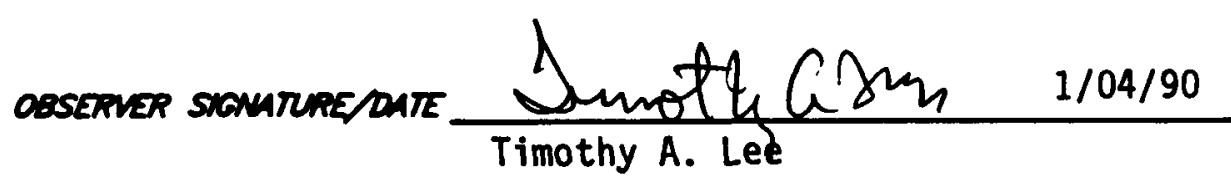




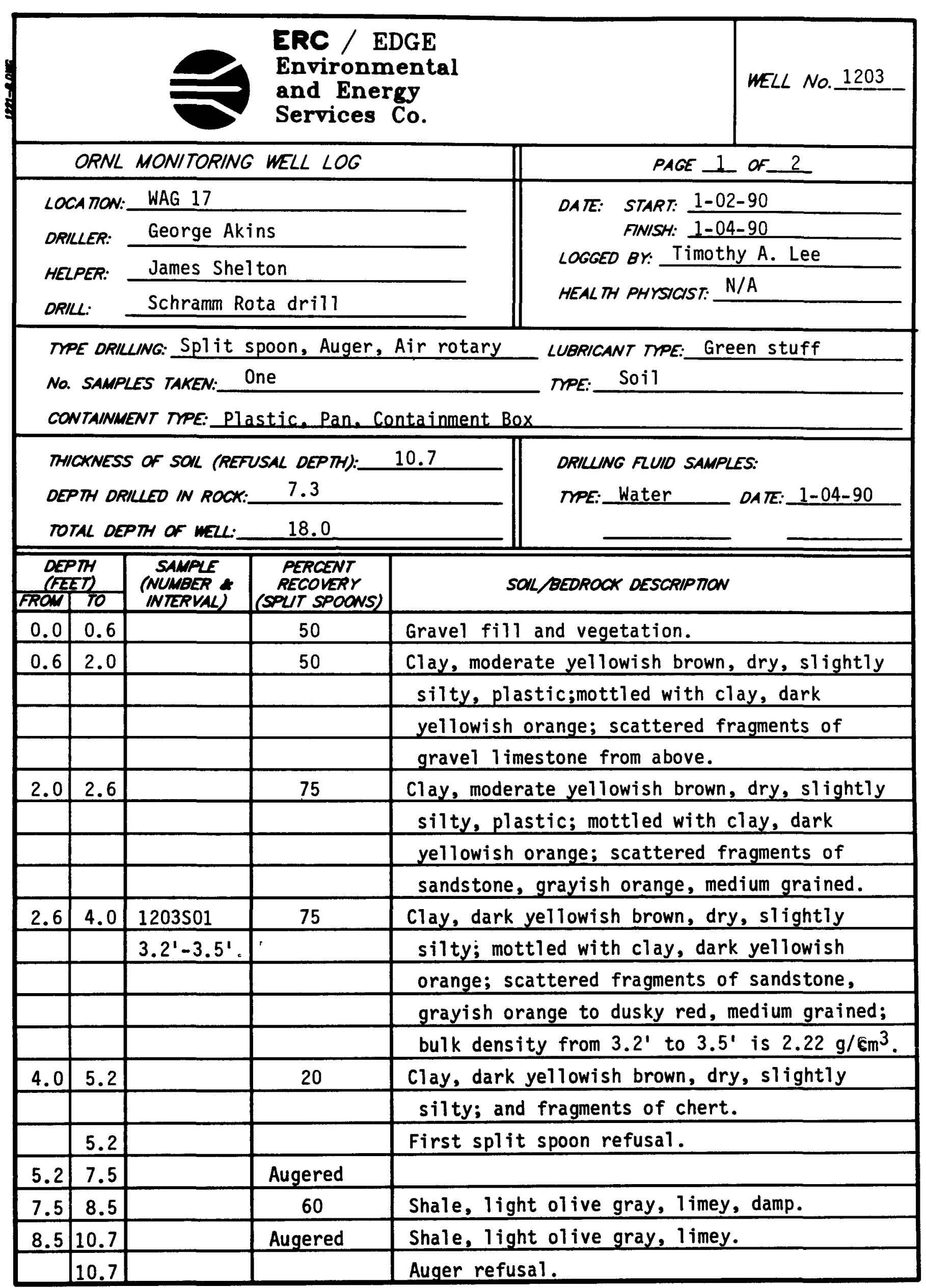




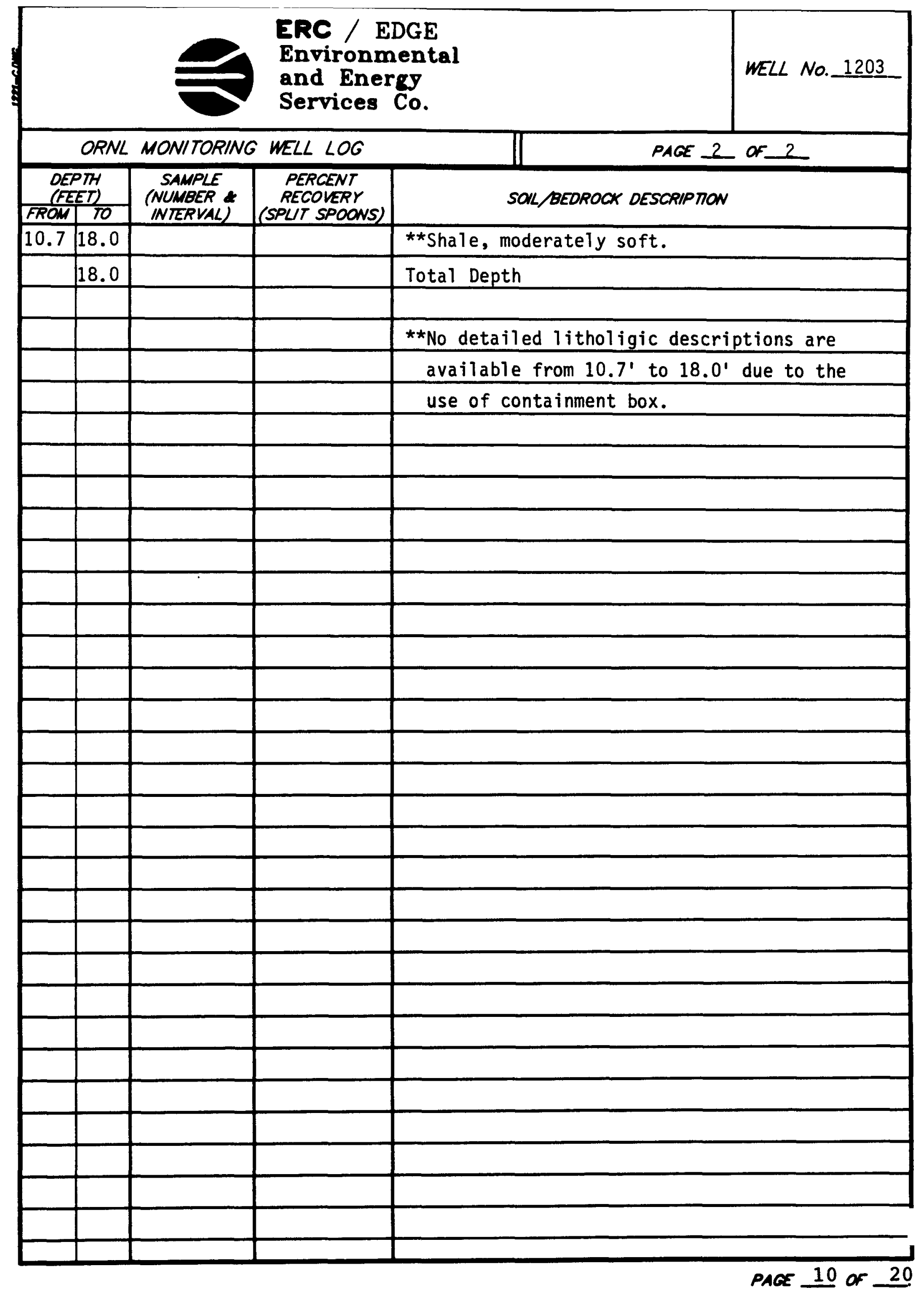




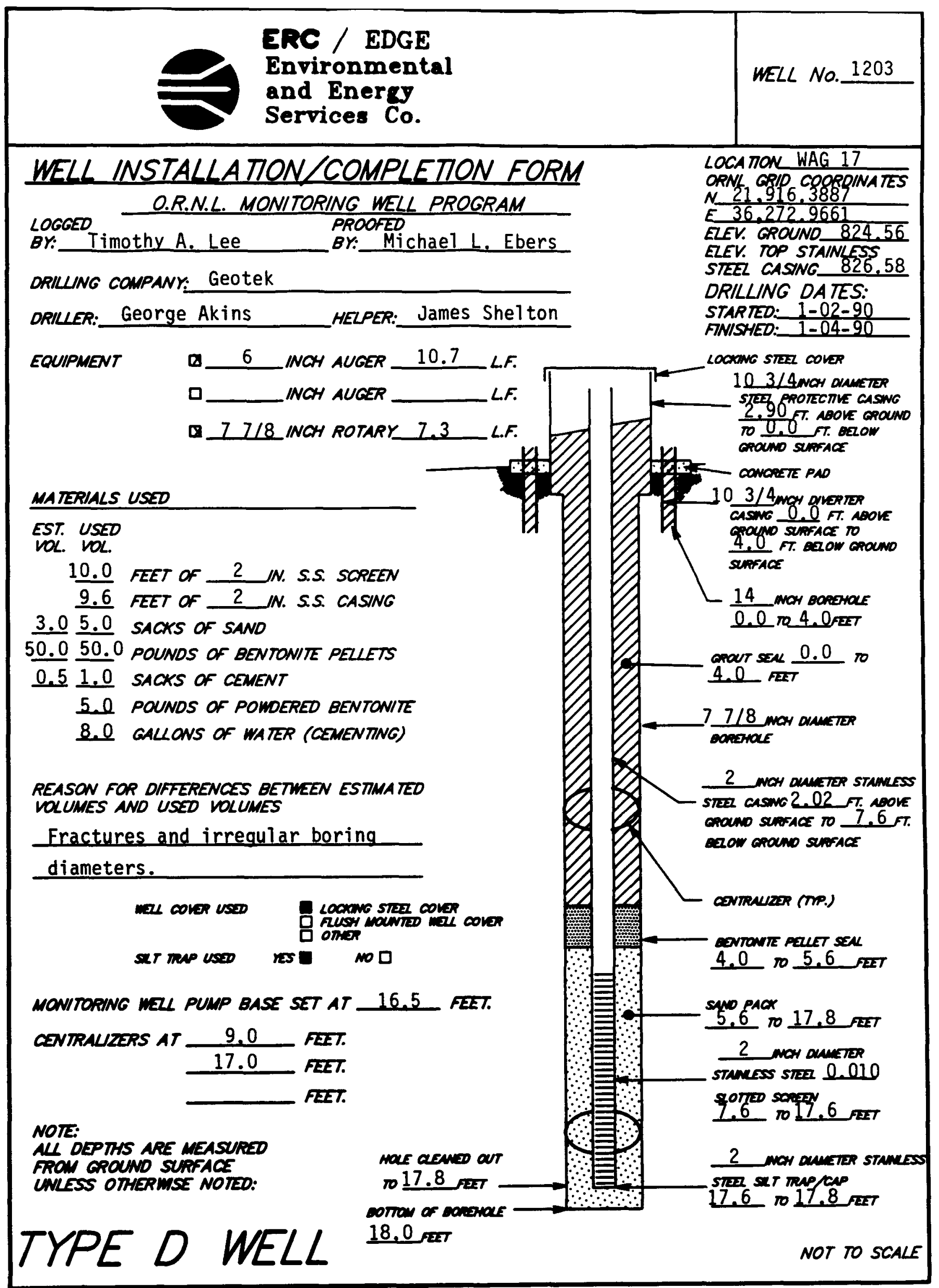

PACE 11 of 20 


\section{ERC / EDGE}

Environmental

WELL NO. 1203

and Energy

Services Co.

DATE: $1-04-90$

\section{MONITORING WELL MATERIALS CERTIFICATION}

ITEM/MA TERIAL

DAIE USED BATCH NUMAER

SAND

BENTONITE

Pellets

STAMLESS STEEL SCREEN

STANLESS STEEL CASNG

STANLESS STEEL CENTRALIZERS

STAMLESS STEEL CAPS

MONITORNG MEL PLMP

(PRespaCxaczo

(PREPACKAGED

(PRDPACKaCED

Powder

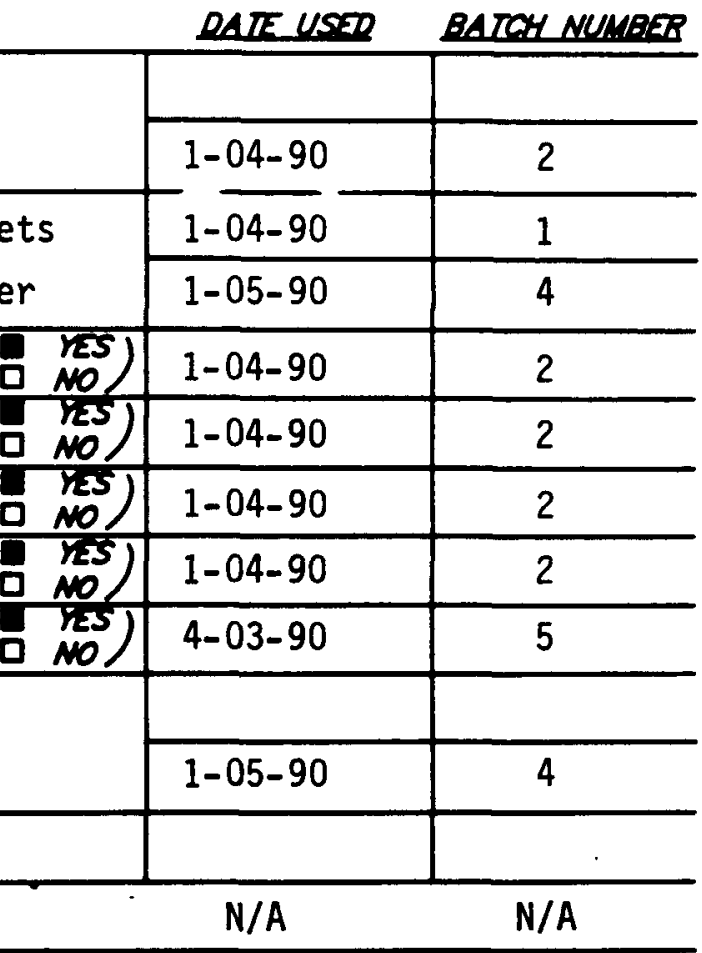

COMMENTS:

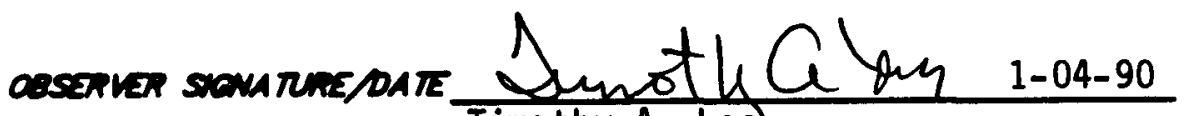
Timothy A. Lee)

D. Chanleo \&utle

4-03-90

D. Charles Lytie

PACE 12 or 20 


\section{POST-MELL COMPLETION CHECKLIST}

\section{ROST-MELL COMPLETION TASKS}

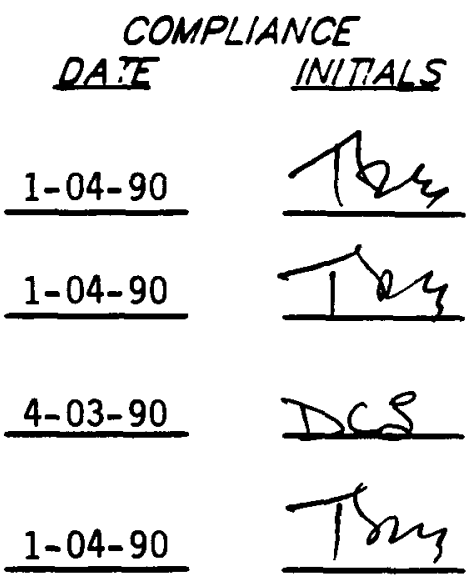

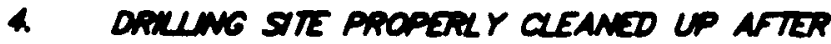

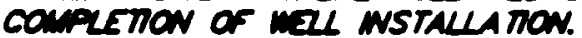

1. WU SCPAPED FRON AUCSRS SMMPLERS ANO NU OTHER EQUIPISNT.

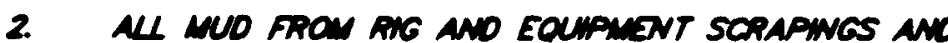

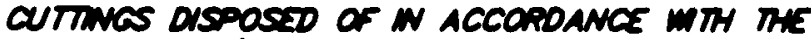
secarich now Provosp.

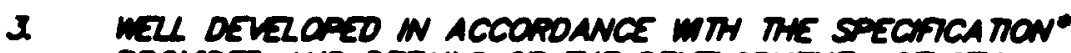

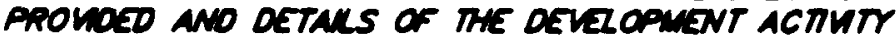
Recanoso.

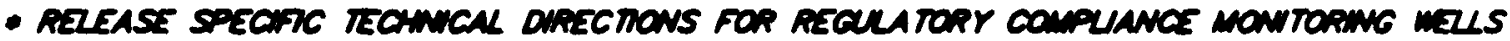

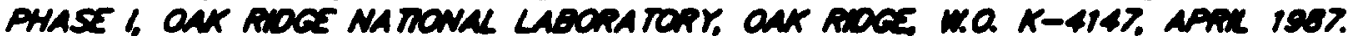

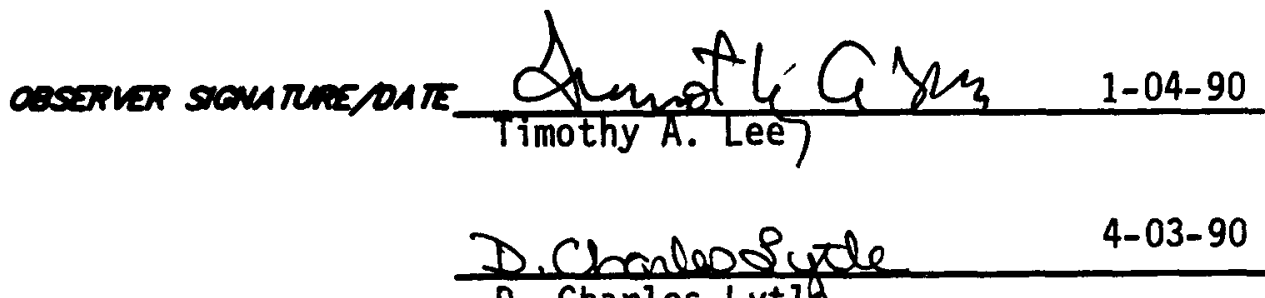

D. Charles Lytie 
ERC / EDGE

Environmental

and Energy

WELL NO. 1203

Services Co.

\section{MONITORING WELL \\ DEVELOPMENT FORM}

DEVELOPMENT DETAILS

METHOD OF

DEVELPMENT: Surging and Pumping

DEVEOPMENT

BEGAN OATE:

$3 / 28 / 90$

TWE:

DEVELOPMENT

ENDING OATE: $4 / 03 / 90$

DEVELOPMENT

OBSERVED BY: D. Charles Lytie

ONE WEL VOLUME: 7.3

ancons

TOTAL GALONS PUMPED: 174 TOTA MEL VOLUNES PUMPED:_-24.0

INITAL PH: 7.4 FNAK PH: 7.4

INITAL CONOUCTUTH (uS): 729 FINAL CONDUCTUTY (US): 707

DESCRIPTION OF INITAL TURBIOIT:_Cloudy

DESCRIPTION OF FNAL TUREIDITY.

Clear

FNAL NEASURED TURBVOITY_ 2.0 NTU'S

WEL APPROVED BY: R. C. Williams MMES

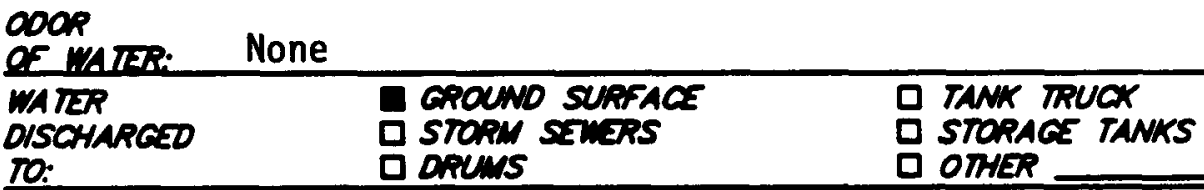

MTIL PAE-OEVELOPENT

WATER DEPTH: $\quad 2.8$ feet from ground surface.

DEVELOPMENT OBSERVA TONS

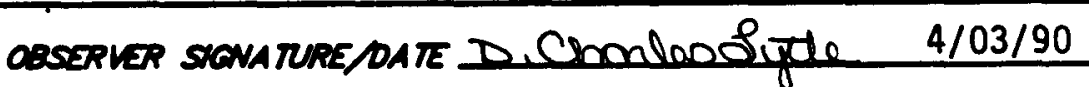

D. Charles Lytle 


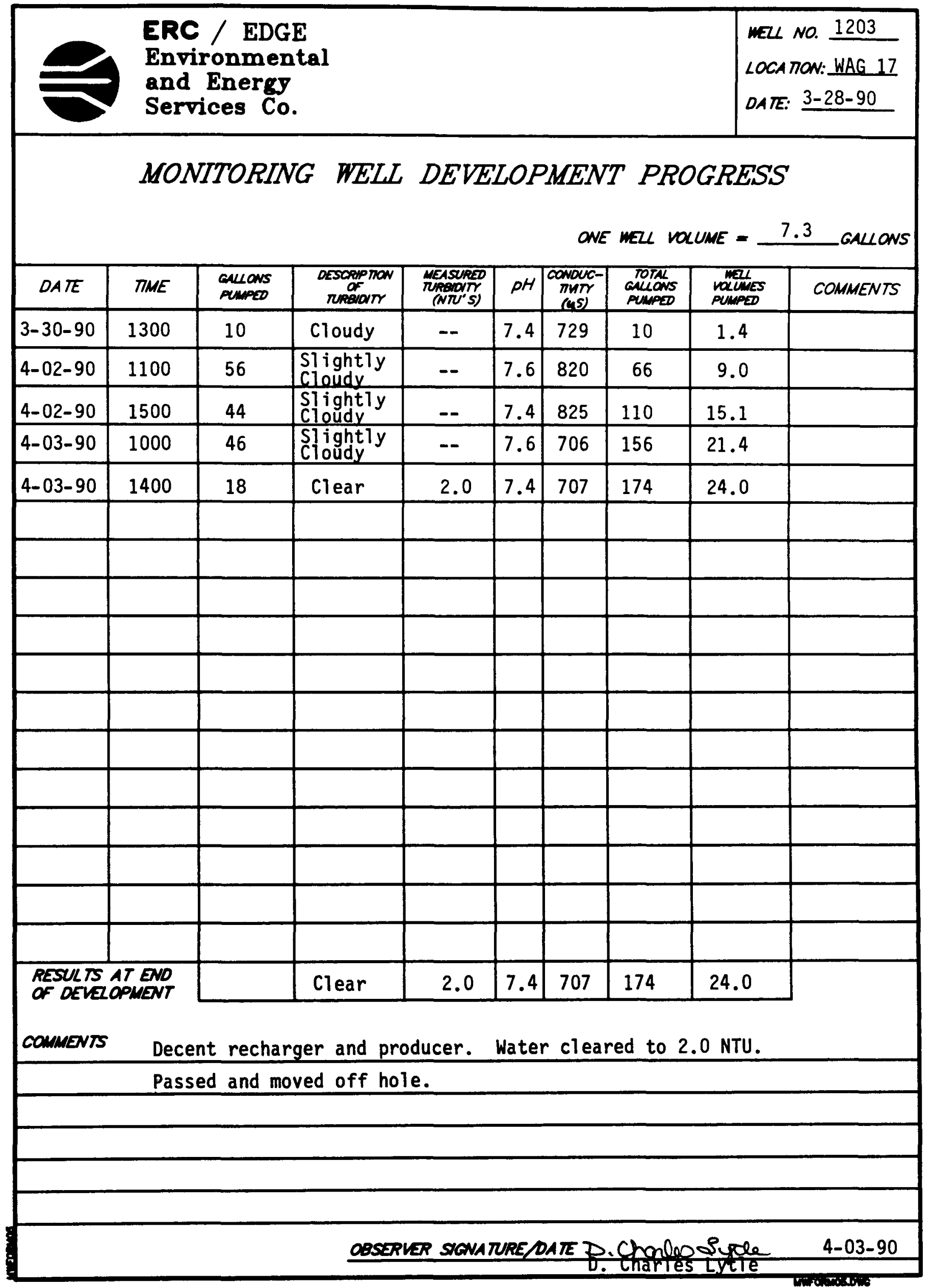




\section{HYORAULIC CONDUCTIVTY CALCULATIONS \\ E

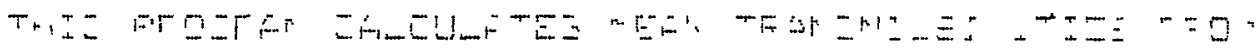

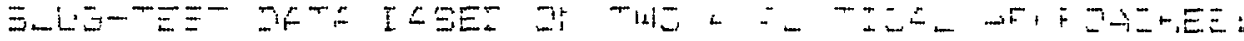

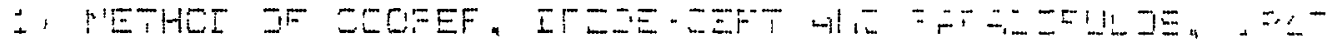

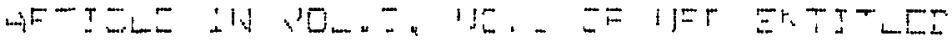

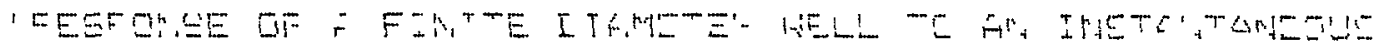 \\ ZMTEE OF MATEF:"

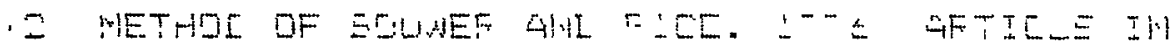 \\ VU.. IE, H . DF MFF EUTTLEI

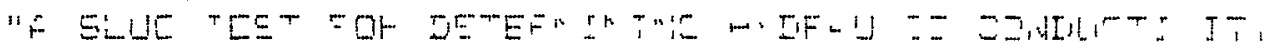

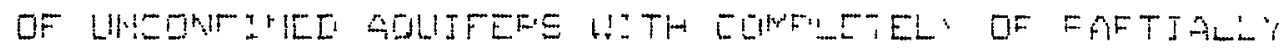

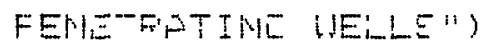

WELL WO. : 1OTE

ELTE UT TEET: 4/1G'ON

FFUJEET ND.: EZZ1-1\%

ELIETIT: MHES

SITE LOCATION* WAE 17

ERGE, INC. FIELD INVESTIGATOF: EFUCE MCMAETEF

\section{INFUT DATA AEE:}

INNEF CASING DIAMETEF $=\approx .00$ INCHES

INHEF SCFEEN QD OFEN-HOLE DIAMETEF $=2.00$ INCHES

DIAMETEF OF DFILLED HOLE $=0.75$ INCHES

LENGTH OF SCFEEN OF INTAYE FOFTION $=10.00 \mathrm{FEET}$

DEFTH FFOM STATIC LEVEL TO EOTTOM OF SCFEEN = 16.60 FEET

THICHNESS DF SATUFATED AOUIFEF ZONE $=10.00 \mathrm{FEET}$

DEFTH TO STATIC WATEF LEVEL BELOW FEF. FOINT = . BS FEET

ESTIMATED FOFOSITY DF GFAVEL FACH $=.20$

FALLING-HEAD JNDEX $=1$ ?"I" IF FALLING "O" IF FISING!

NUNIEEF: OF DEF'TH-TIME DATA FOINTS = 20

HO WAS COMFUTED FFOM INTERCEFT OF FLOT OF LDG(H) VS. TIME

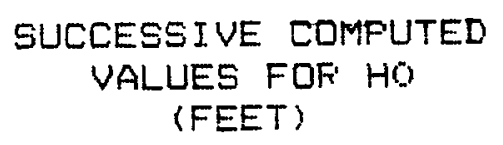




\section{HYDRAULIC CONDUCTVIY CALCULATIONS}

$\ldots=\cdots$

$=E:-$

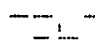

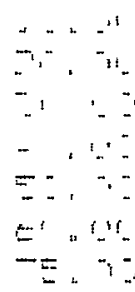

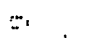

$\therefore \equiv \ldots$

$+20,13$

- Evar

$18 \%, 7 \%$

$z+1 \therefore 2$.

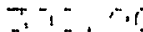

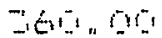

$4=\because \because \therefore$

IE:

ESA:O

60.

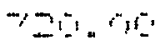

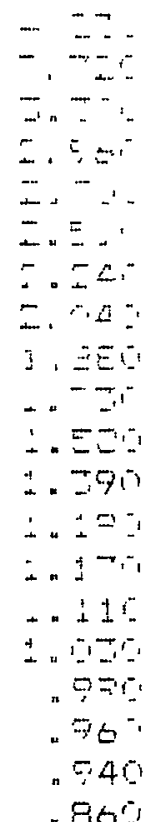

$\because \cdots$

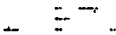

- 국두.

-1.19

$\ldots \equiv$

1. 6

$\therefore-\pi$

a

$\therefore \quad=$

$=-1$

$-7$

$52=$

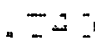

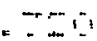

$= \pm$ is

$\therefore 2$.

$.74:$

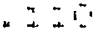

.90

$.80 \%$

.910

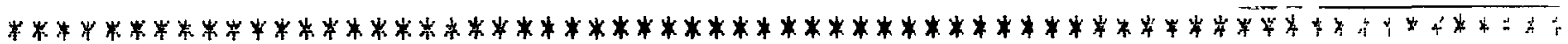

METHOD OF EOUWEF AND FIICE

COMIJUED FESULTS USING DIAMETEF OF DFILLED HOLE:

FEFMEAEILITY $=6.48 E-06 \mathrm{FT} /$ SECONDS $=1.97 \mathrm{E}-04 \mathrm{LM} / \mathrm{ELC}$

TFANSMISSIVITY $=6.48 E-05$ FT** Z'SECONDS

COMFUTED FESULTS USINE DIAMETEF OF CASING AND SCFEEN:

FEFMEAEILITY $=8.75 E-06 \mathrm{FT} /$ SECONDS $=2.67 \mathrm{E}-04 \mathrm{CM} / \mathrm{SEC}$

TFANSMISSIVITY $=8.75 E-05$ FT**2/SECONDS 


\section{ERC / EDGE \\ Environmental \\ and Bnerg \\ Services Co.}

MEL No. 1203

\section{HRRAULIC CONDUCTUTY GALCULATONS}

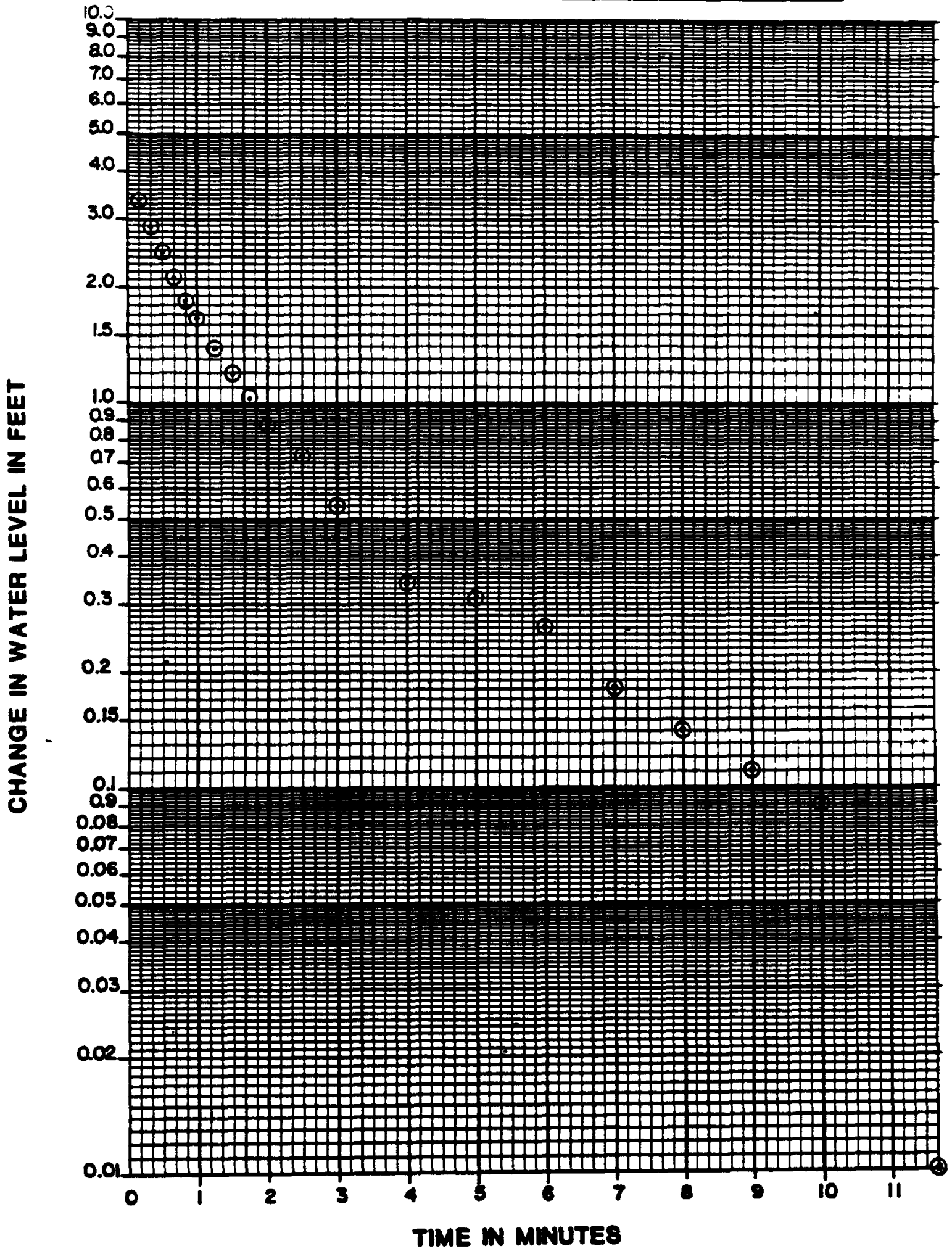

PAer 18 or 20 


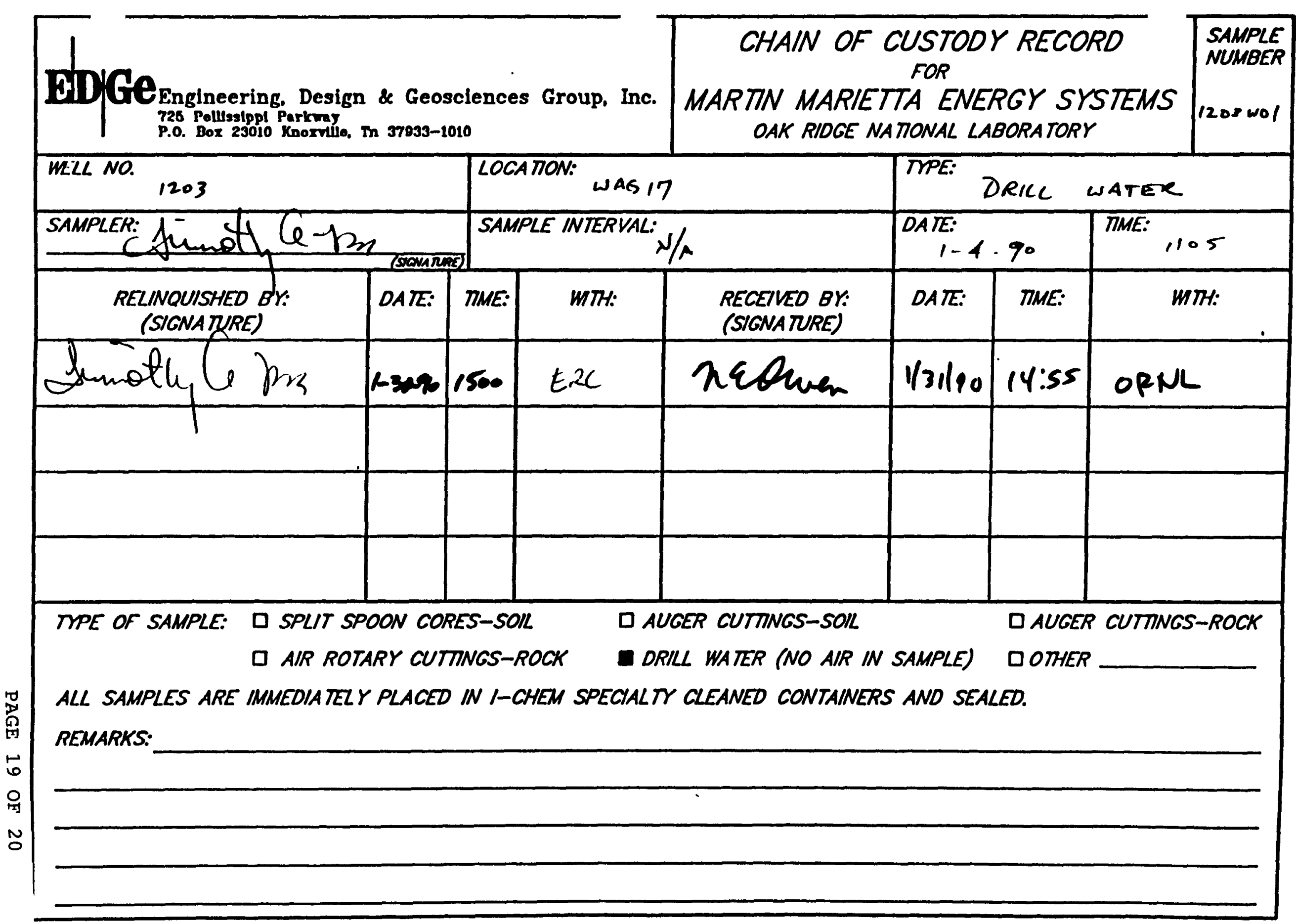




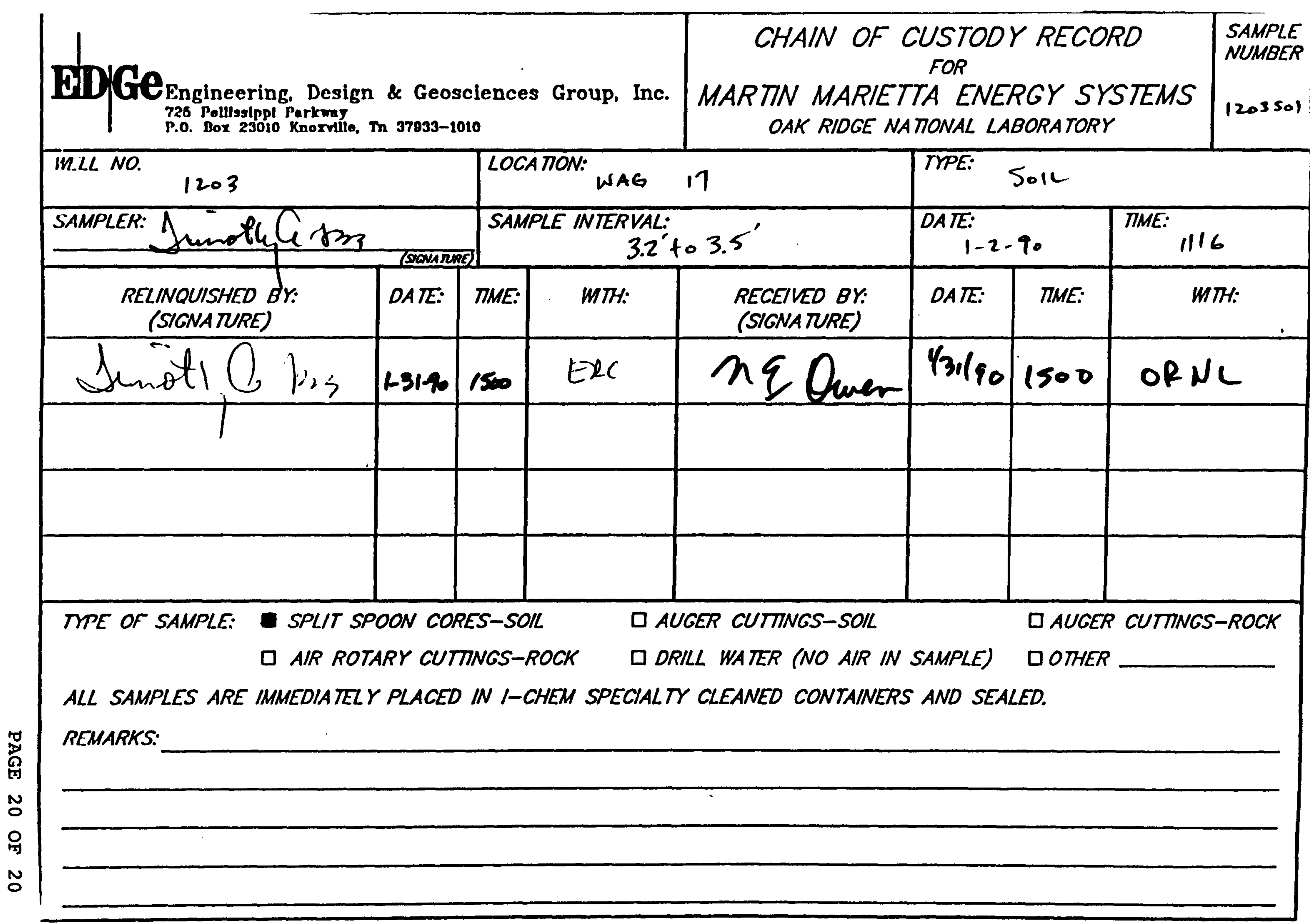




\section{Appendix B}

Operating Instructions for Handling Water and Cuttings from Well Drilling and Development of Groundwater Quality Monitoring Wells 

OPERATING INSTRUCTIONS FOR HANDLING CUTTINGS AND WATER FROM FROM VELL DRILIING AND DEVELOPMENT OR THE GROUNDWATER QUALITY MONITORING WELLS

Prepared by

J. A. Greene 



\section{PROCEDURE REVIEW AND APPROVAL Form}

Environmental and Health Protection Division

Operating Instructions for Handing Cut ings and hater from

Procedure Title hell Drilling and Development of the Groundwater Cualitv

Procedure No. Yonitoring Wells

Author

REVIEW AND APPROVALAt a minImum. procedures ere epproved by the manager or ine Implementing unli and the next nloher level manager. SOP, must be revlewed by OA siall lo eseure inet QA requiremente are met and to verlfy that eppllcable etandarda are apecilied. signatures of the epprovers MUST appeer on the lirel page of each approved procedure.

The required approvers and the OA revlewer muet elon below.

Approved by:
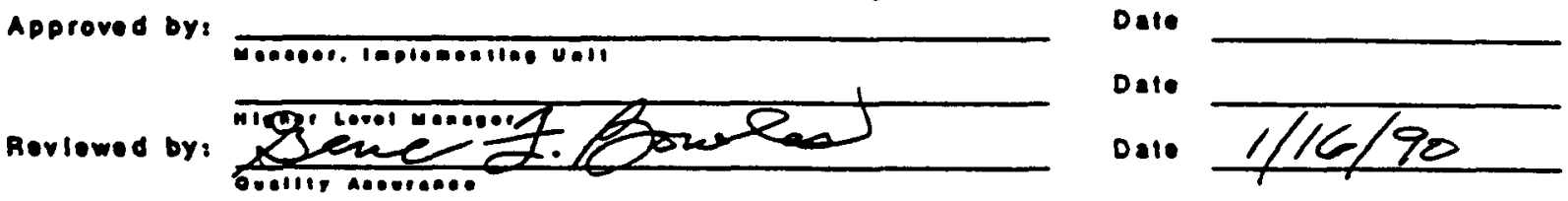

In the speces below Indleate additlonal reviews (R) of epprovals (A). All revtewers and approvere muet blon and deto inlo lorm botore the procedure can be linally opproved. ll more then one proceudre le belno revlewed, altech llet.

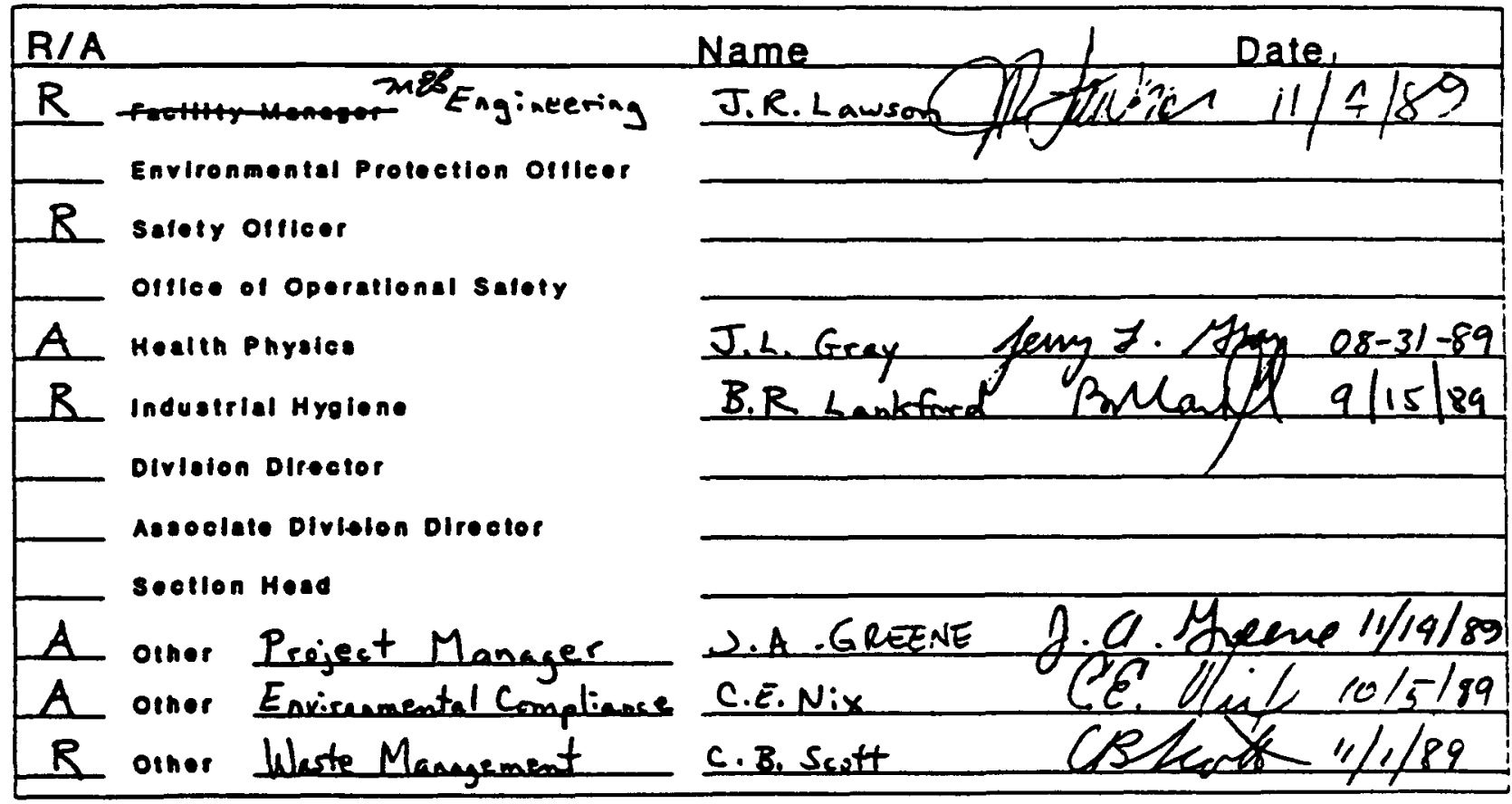

Is revision of the SARIOSR required _ YES X NO

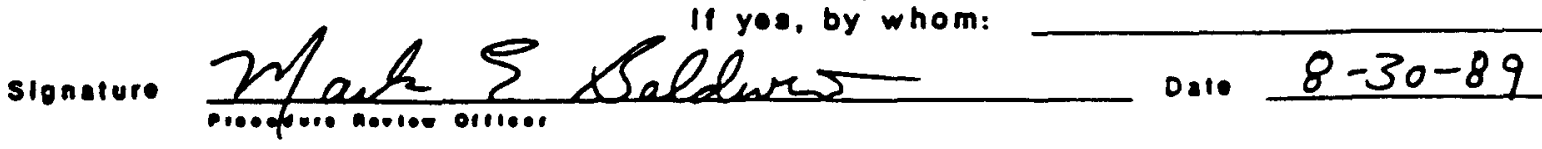

Next revlow deses: 2uyes.

Forward a completed copy of thle form to the division OA Ollice. $4500 \mathrm{~N}$, MS-6186. 


\section{OPERATING INSTRUCTIONS FOR HANDLING CUTTINGS AND WATER FROM \\ FROM WELL DRILLING AND DEVELOPMENT OF THE \\ GROUNDWATER QUALITY MONITORING WELLS}

1.0 PURPOSE

The purpose of this document is to cite the steps that are followed to handle water and soil produced during the installation and development of wells.

2.0 SCOPE

This document applies to well drilling and development associated with the Groundwater Quality Monitoring Wells Installation Program at Oak Ridge National Laboratory.

\subsection{REFERENCE}

Health, Safety, and Environmental Protection Procedures for Excavating Operations, ORNL/M-116/R1, Oak Ridge National Laboratory, March 3, 1988.

\subsection{DEFINITIONS}

Well Ratings. Ratings assigned during the excavation permit cycle by Radiation Protection (RP) and Industrial Hygiene (IH) to indicate the probability of encountering radioactive and chemical contamination, respectively. These ratings are based on historical information or from previous drilling or excavation activity. The ratings are marked on the excavation permits. (RP ratings on permits may sometimes be called "HP'" for "Health Physics." The two designations are interchangeable.) Protective measures required for the three categories are stated in Table 1, "Excavation-classification categories," in ORNL/M-116/R1. The categories for soil handling are stated in Appendix B, 'Radiological Soil Handling Criteria,' in ORNL/M-116/Rl.

RP Category 1. A rating assigned by RP which indicates that the probability of encountering radioactive contamination is low and that intermittent monitoring is required by $R P$.

IH Category 1. A rating assigned by IH which indicates that the probability of encountering chemical contamination (i.e., organics) is low and that monitoring is not required by IH. An IH and/or Environmental Monitoring and Compliance (EM\&C) representative will be called in any time chemical or hazardous contamination is suspected.

RP Category 2. A rating assigned by $R P$ which indicates that the probability of encountering radioactive contamination is moderate and that continuous monitoring is required. The RP representative will determine the necessary level of protective clothing to be worn.

IH Category 2. A rating assigned by IH which indicates that the probability of encountering chemical contamination is moderate and that respirators must be on-site and ready for use by the workers when 
indicated by the IH or RP representative on-site. Location will be checked periodically with an IH field instrument, such as a Photovac or Organic Vapor Organizer (OVA).

RP Category 3. A rating assigned by RP which indicates that there is a high probability of encountering radioactive contamination. Therefore, continuous monitoring by an RP representative is required, and protective clothing must be worn. In addition to the training listed above, workers must have successfully completed the Category 3 Driller Training course that is administered by Environmental and Health Protection Division (E\&HP) personnel.

IH Category 3. A rating assigned by IH which requires the workers to wear respirators as a minimum. Additional protection deemed appropriate by IH will be designated for each location. Continuous monitoring by IH personnel is required.

Training Requirements. Training requirements for workers include the Basic Radiation Training administered by E\&HP personnel and the $40 \mathrm{~h}$ of training required by the Superfund Amendment Reauthorization Act (SARA) through a company-approved course. There is an additional training course required for Category 3 drilling.

Air rotary containment box. A box specially designed to contain the cuttings and water that are blown from the borehole during air rotary drilling. The box is equipped with a high-efficiency particulate air (HEPA) filter to prevent particles that possibly contain contaminants from being dispersed into the air. Air rotary drilling is generally used only for drilling into bedrock.

Auger pan. A metal catch pan with a hole cut in the middle. The pan surrounds the borehole and contains soll cuttings as they are augered up.

Proper On-Site Disposal. Disposal of noncontaminated soil and water produced from work on a well at a location near the well that is not openly visible to the public and has no risk of causing erosion or direct discharge into a stream. The construction engineer (CE) will indicate to the drillers which areas are acceptable for on-site disposal. The $\mathrm{pH}$ will have been checked and adjusted to the 5-to-9 range before releasing. This precise definition is intended wherever this term is used in this procedure.

Proper Contaminated Waste Disposal. Generally, radioactively contaminated soil will be packaged in drums and tagged by the RP representative for disposal by ORNL Waste Operations. However. Category-2-level soil may be used on site as backfill in remote areas when covered by $1 \mathrm{ft}$ of noncontaminated soil as stipulated in ORNL/M$116 / R 1$. The $C E$ will specify to the drillers when a well location has been approved by EM\&C for on-site disposal of contaminated soll. This definition is intended wherever this term is used in this procedure. 
Temporary Drilling Equipment Cleaning Facllity. An outdoor area located in Melton Valley for steam cleaning of drill rigs and associated equipment, referred to as the steam cleaning area.

Contalnment Box Holding Pit. A lined pit at the Temporary Drilling Equipment Cleaning Facility. The contents of the pit will be sampled and tested for gross alpha, gross beta, $\mathrm{pH}$, and tritiun*, before being released through a silt fence. Contents that have a potential for containing hazardous materials (i.e., IH Category 2 and 3 locations) will have been checked with an IH field instrument before being released into the pit.)

Steam Cleaning Pits. Two lined pits at the Temporary Drilling Equipment Cleaning Facility that collect runoff from the steam cleaning operations. The contents of the pits will be sampled and tested for gross alpha, gross beta, pH, and tritium*, before being released through a silt fence. Contents that have a potential for containing hazardous materials (i.e., IH Category 2 and 3 locations) will have been checked with an IH field instrument before being released into the pit.)

\subsection{RESPONSIBIIITIES}

5.1 Radiation Protection Personnel monitor and determine the presence of detectable radioactive contamination in drill cuttings during well-drilling activities. They provide guidance to ensure that exposures to the workers, public, and environment are kept as low as reasonably achievable. They also provide radiation monitoring during the precursory cleaning by the drillers.

5.2 Well-Drilling Personnel perform well drilling and completion activities. They package soll and water in appropriate containers and transport 1t, if necessary; perform precursory cleaning of low-level contaminated equipment; and perform cleaning of equipment between the drilling of each well.

5.3 EDGe Hydrogeologists observe all crucial well installation activities and record data for all boreholes drilled. They do a visual inspection of the cuttings produced during augering and note any unusual occurrences and obvious deleterious material encountered during the drilling process. They check the cuttings and water with a Photovac or OVA or similar instrument and check pH of water when necessary.

5.4 Construction Engineer serves as the field contact and provides guidance to the drillers during field activities.

\subsection{PROCEDURE}

\subsection{EXPLANATION OF THE WELL RATING SYSTEM}

Each well is assigned a rating by $R P$ and $I H$ before drilling begins. Because additional information is gained during drilling, 
well ratings may be changed by $R P$ and $I H$ as the work progresses. A lower RP Category rating will be changed to a Category 3 rating upon encountering radioactive contamination within the Category 3 range defined in $O R N L / M-116 / R 1$. Likewise, an IH Category 3 may result if chemical contamination is detected in a well with a lower rating. The RP and/or IH representative on site will notify the on-site personnel when conditions warrant a rating change. Any additional actions or modifications in protective clothing required by the rating change will be executed at that time. The change will be documented immediately by the on-site hydrogeologist in the well data package and as soon as possible by the RP and/or IH representative by a signed written statement stating the well number, the old and new ratings, and the rationale supporting the change. The statement will be sent by the RP and/or IH representative to the Construction Engineer (CE) for filing with the original excavation permit. A copy will be sent to the RAP Well Installation Manager by the CE.

A well category also may be changed from a higher rating to a lower rating. For example, if no contamination is encountered while drilling a Category 2 or 3 well, it may be changed to a lower rating after drilling to a certain depth or for development purposes, depending on the history of the area. The documentation procedure stated above for an increase in rating must also be followed for a decrease in rating.

\subsection{CATEGORY 1 WELLS (RP OR IH)}

\subsubsection{Category 1 Drilling}

\subsubsection{Category 1 Auger Cuttings}

a. Auger cuttings will be collected in a catch pan.

b. An RP representative will scan the cuttings intermittently to check for radioactive contamination. Cuttings will be inspected for any unusual discoloration or odor by the hydrogeologist.

c. If there is no contamination detected, proper on-site disposal or disposal at the steam cleaning area will be done.

\subsubsection{Category 1 Air Rotary Drilling}

a. Cuttings will be collected in a containment box.

b. When the containment box is full, one of the following will be done to empty cuttings and/or decant water from the containment box: 
(2) disposal at the containment box holding pit.

6.2.2 Category 1 Well Development

6.2.2.1 Water removed from the well will be contained in drums.

6.2.2.2 The $\mathrm{pH}$ of the water will be measured and will be adjusted to be between 5 and 9 by the $C E$ if it is above or below that range.

6.2.2.3 Drums of water will be discarded by proper on-site disposal or disposal at the steam cleaning area will be done.

\subsection{CATEGORY 2 WELIS (RP AND IH)}

\subsubsection{Category 2 Drilling}

\subsubsection{Category 2 Auger Cuttings}

a. Auger cuttings will be collected in a catch pan.

b. An RP representative will scan the cuttings continuously to check for radioactive contamination. Cuttings will be inspected for any unusual discoloration or odor and tested with a Photovac or OVA by the hydrogeologist for presence of RCRA materials.

c. If there is no contamination detected, proper on-site disposal or disposal at the steam cleaning area will be done.

d. Cuttings will be contained in drums if contamination is detected. Proper disposal will be arranged by Martin Marietta Energy Systems through Waste Operations.

\subsubsection{Category 2 Air Rotary Drilling}

a. Rock cuttings and drill water will be collected in a containment box.

b. When the containment box becomes full, the RP representative will perform a wet towel smear to detect the presence of radioactive contamination. An inspection for unusual discoloration or odor and tests with an OVA will be conducted for the presence of RCRA materials by the hydrogeologist. 
c. If no contamination is detected, one of the following will be done to empty cuttings and/or decant water from the containment box:

(1) proper on-site disposal.

(2) disposal at the containment box holding pit.

d. If contamination is detected by the tests, arrangements will be made by Martin Marletta Energy Systems through Waste Operations to properly dispose of the water. Further laboratory testing of the box contents may be done.

\subsubsection{Category 2 Development}

6.3.2.1 Water removed from the well will be contained in drums.

6.3.2.2 When the drums are ready to be emptied, the RP representative will perform a wet towel smear to detect the presence of radioactive contamination. An inspection for unusual discoloration or odor and tests with an OVA will be conducted for presence of RCRA materials by the hydrogeologist. The $\mathrm{pH}$ will be adjusted if necessary.

6.3.2.3 If no contamination is detected, the water will be discarded by proper on-site disposal or disposal at the steam cleaning area will be done.

6.3.2.4 If contamination is detected by the tests, arrangements will be made by Martin Marietta Energy Systems to properly dispose of the water. Further laboratory testing may be done.

\subsection{CATEGORY 3 WELLS (RP AND IH)}

\subsubsection{Category 3 Drilling}

\subsubsection{Category 3 Augering}

a. When well is classified as an RP Category 3 or an IH Category 3, continuous monitoring will be required by RP and IH. Wearing of respirators will be required. Cuttings will be inspected for any unusual discoloration or odor. Tests for chemical contamination (i.e., organics) will be performed with IH field instruments by an IH representative for IH Category 3 wells. Specially trained personnel will be required to do the drilling. 
b. If no contamination is detected by RP or IH while augering through soil to bedrock, a rating may be changed by RP or IH to a Category 2 depending on the depth, the type of contamination expected, and the history of the area.

c. If contamination is detected during augering, cuttings will be drummed. Proper disposal of all cuttings and water will be arranged by Martin Marietta Energy Systems.

6.4.1.2 Category 3 Air Rotary Drilling

a. Rock cuttings and drill water will be collected in a containment box.

b. When the containment box becomes filled with water and/or cuttings, a sample will be collected by EM\&C and will be tested by the Analytical Chemistry Division for gross alpha, gross beta, tritium*, for an RP Category 3. If it is an IH Category 3, the IH representative on-site will determine which (if any) laboratory testing is necessary for chemical contaminants.

c. Proper disposition of the containment box contents will be decided by consensus of E\&HP, the IH or RP representative, EM\&C, and the $C E$, based on the results from Analytical Chemistry Division of the above tests.

\subsubsection{Category 3 Development}

6.4.2.1 Water pumped from Category 3 wells will be contained in drums. Samples will be collected by EM\&C and will be tested by Analytical Chemistry Division for gross alpha, gross beta, tritium*, and $\mathrm{pH}$. It will be tested with IH field instruments by IH representatives for the presence of RCRA materials.

\subsubsection{A decision based on the test results will be made between E\&HP and Engineering whether to continue development.}

\subsection{BOREHOLE CLEANING}

When sludge and water have accumulated in the bottoms of boreholes drilled in soil, the boreholes must be cleaned out prior to setting casings. A decision based on the location of the borehole and its rating will be made between the RP and/or IH representatives whether the sludge and water from the borehole must be contained in a drum. Water and sludge from a Category 2 well will be drummed, and a wet towel smear will be done by RP to 
determine proper disposal of the drum contents. Laboratory testing of the drum contents for gross alpha, gross beta, tritium*, and $\mathrm{pH}$ will be done if recommended by the RP or IH representative. Water and sludge removed from an RP Category 3 well will be drummed, and laboratory testing will be done for gross alpha, gross beta, tritium*, and pH. EM\&C will be consulted to determine proper disposal based on the test results. Further laboratory testing to determine actual contaminants will be done if recommended by EM\&C.

"Testing for tritiun will be done for wells located in areas where tritiun contamination is suspected. This decision will be made between RP and EMRC. 


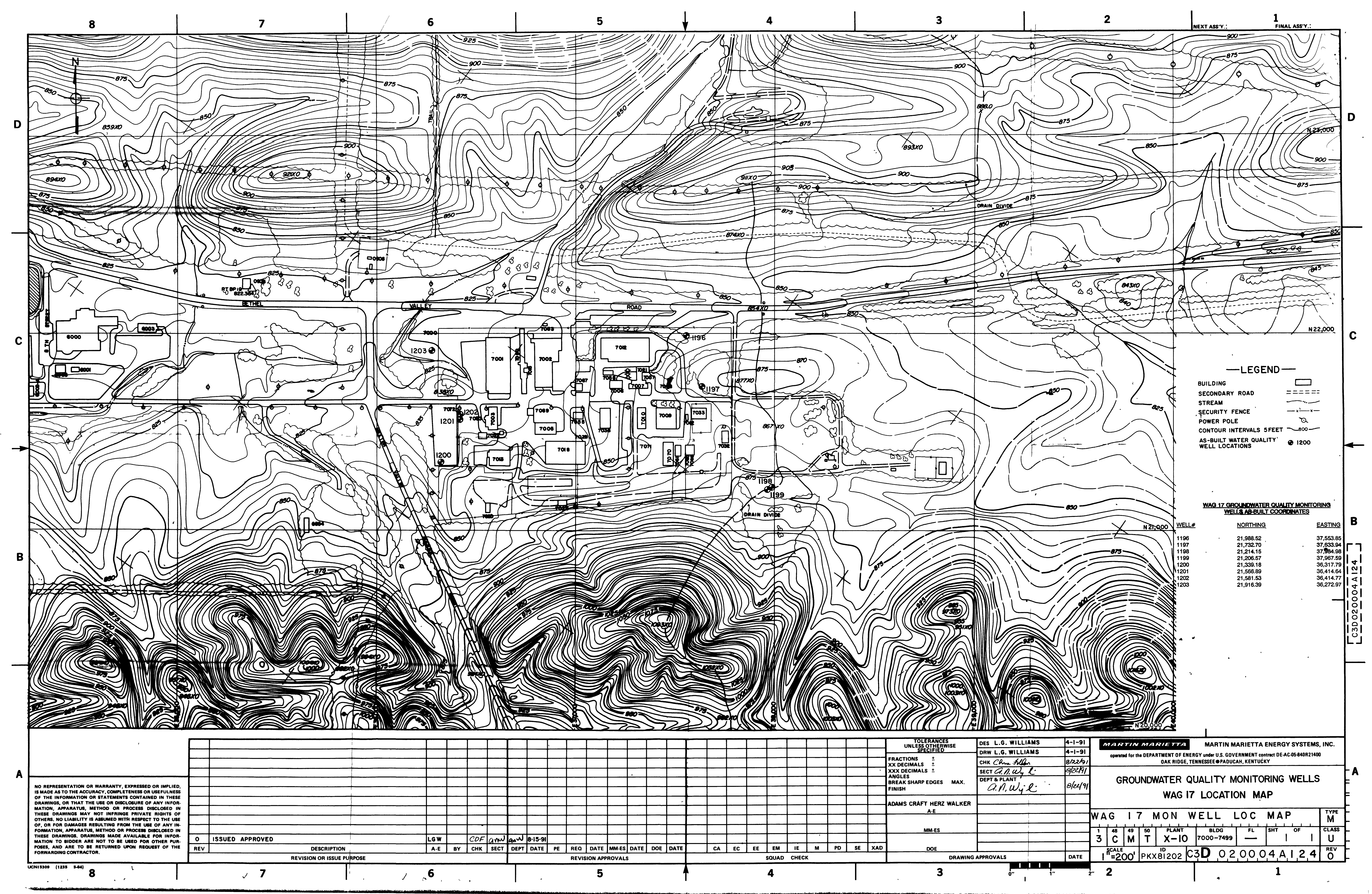




\section{DISTRIBUTION}

1. F. P. Baxter

2. H. L. Boston

3. W. D. Brickeen

4. T. A. Early

5. M. L. Ebers

6. R. H. Ketelle

7-9. D. M. Matteo

10. J. A Mortimore

11-12. P. T. Owen

13. P. A. Schrandt

14. M. M. Stevens

15. P. S. Wood

16-18. ORNL ER Document Management Center

19. ORNL Patent Section

20-22. Central ER Document Management Center

23. Laboratory Records Department

24. Central Research Library

25. Office of Assistant Manager for Energy Research and Development, DOE Oak Ridge Operations Office, P.O. Box 2001, Oak Ridge, TN 37831-8600

26-27. Office of Scientific and Technical Information, P.O. Box 62, Oak Ridge, TN 37831 